$$
\text { UNIVERSIDADE DE SÃO PAULO }
$$

FACULDADE DE FILOSOFIA, LETRAS E CIÊNCIAS HUMANAS

DEPARTAMENTO DE LETRAS CLÁSSICAS E VERNÁCULAS

PROGRAMA DE PÓS-GRADUAÇAO EM

ESTUDOS COMPARADOS DE LITERATURAS DE LÍNGUA PORTUGUESA

\title{
Entre Percursos e Berros: o eu entretecido por fios de memória em Wanda Ramos e em Tereza Albues
}

\author{
Leonice Rodrigues Pereira
}

Tese apresentada ao Programa de PóGraduação em Estudos Comparados de Literaturas de Língua Portuguesa do Departamento de Letras Clássicas e Vernáculas da Faculdade de Filosofia, Letras e Ciências Humanas da Universidade de São Paulo, para obtenção de título de Doutor em Letras.

Orientadora: Profa. Dra. Tania Celestino Macêdo 
[...] é impossível restaurar o passado em estado de pureza. Basta que ele tenha existido para que a memória o corrompa com lembranças superpostas. [...] A viagem da memória não tem possibilidades de ser feita numa só direção: a do passado para o presente. Não é a sós que velejamos para os anos atrás em busca de nossos eus. Levamos conosco uma experiência tão inarrancável que ela é elemento de deformação que nos obriga a agir com as nossas recordações [...]

(Pedro Nava) 
A meus pais, Sebastião e Catarina.

À minha avó Porcina Angélica (in memorian), por rememorar sua história comigo desde minha infância e assim atrair meus olhos para as fecundas habilidades da memória. 


\section{AGRADECIMENTOS}

A presença do "outro" em mim foi algo que sempre me impressionou na vida desde muito antes da leitura de Bakhtin; pelo que recordo, desde meu tempo de menina. Nesse sentido, faz-se necessário refletir sobre o quanto foi importante para a realização desta pesquisa o diálogo com meus alunos, colegas e amigos professores, pesquisadores, com todos com quem convivi no cotidiano, dos quais recebi carinho, afeto e reconhecimento por minhas ações e atitudes positivas no âmbito do profissional, intelectual e pessoal, combustível valioso para o desenvolvimento e a conclusão deste trabalho. No cume de toda essa relação estabelecida com o "outro", está a interação com o Divino, capaz de nos ajudar a fazer dos percalços e dos desafios encontrados pelo caminho tônicos para nosso crescimento, nessa busca permanente pelo que há de melhor em nós, seres humanos, aptos a se modificarem continuamente.

Por todas essas razões e muitas outras, sou grata a todos que colaboraram direta ou indiretamente pela realização desta pesquisa.

Agradeço:

À Profa. Dra. Tania Celestino Macedo, por acreditar em minha proposta de pesquisa, no meu potencial, pelo apoio, incentivo ao trabalho realizado e por toda dedicação e orientação valiosa que recebi;

À profa. Dra. Rita Chaves, por me receber como orientanda na fase inicial deste Doutorado, pelos ensinamentos e pela contribuição dada para o desenvolvimento desta tese no exame de qualificação;

Ao prof. Dr. Mario Lugarinho, pela leitura da pesquisa e pelas sugestões dadas no exame de qualificação;

Ao prof. Dr. Benjamin Abdala Junior, pelos ensinamentos importantes;

À Profa. Dra. Yasmin Nadaf, pela contribuição dada na efetivação dos trabalhos de pesquisa da autora Tereza Albues;

Aos colegas professores Agnaldo Rodrigues, Genivaldo Sobrinho, Vera Maquêa, Ana Rabecchi, Elizabeth Batista, Susanne Castrillon, Elair de Carvalho, que contribuíram de forma direta ou indireta para a realização deste trabalho e também pelo que têm me ensinado; 
A Profa. Fabíola Sartin, chefe do Departamento de Letras, pelo apoio dado;

À Profa. Dra. Olga Maria Castrillon Mendes, por apresentar, há muito tempo, este instigante e envolvente romance de Tereza Albues;

À Profa. Marinei Almeida, pelo carinho e pela contribuição na conclusão da pesquisa;

Às professoras Maristela Sarian e Judite Albuquerque, pela leitura dos textos da tese;

À Profa. Clemência Gomes, pela contribuição nos trabalhos finais de organização técnica da tese;

À Nancy Yung, pela amizade, pelo apoio e incentivo;

A todos os demais colegas professores e funcionários da UNEMAT e, em especial, do Departamento de Letras;

Aos professores e funcionários do Departamento de Letras Clássicas e Vernáculas, do Centro de Estudos Portugueses e do Programa de Pós-Graduação em Estudos Comparados de Literaturas de Língua Portuguesa - FFLCH/USP;

Aos meus alunos e ex-alunos, por serem uma das maiores razões desta luta incansável pelo conhecimento e pelo desenvolvimento da pesquisa e também pelo que têm me ensinado, justamente pelos seus olhares do lugar de acadêmicos;

Às pessoas que estão ou estiveram em minha casa nos últimos cinco anos, Gregória, Maria José, Norma, Célia, Geisa Aparecida, Ana Lúcia, efetuando o trabalho doméstico, para que eu pudesse dispor de tempo suficiente para a pesquisa e o ensino;

Aos grandes amigos, Rosely e Márcio, pelo afeto e apoio quando precisei nas viagens para São Paulo;

Ao Aparecido de Assis, pelo companheirismo, afeto, e incentivo nos estudos realizados, pelas discussões sobre a vida e sobre a pesquisa;

Aos meus filhos, Flávio Rodrigo e Luana de Assis, por existirem e por tudo que têm me ensinado;

Aos meus amigos de todas as horas, Geni e João Ivo, por tudo que me ensinaram da vida, pelo amor e pela presença infalíveis, tanto nas vitórias quanto nas derrotas, e também à filhinha deles, Luana Carolina, pelo carinho e seu sorriso.

À CAPES, pelo financiamento da bolsa por meio do PQI; 
À UNEMAT, através do Departamento de Letras de Cáceres, Instituto de Linguagem e da Pró-Reitoria de Pesquisa e Pós-graduação, por conceder-me o afastamento completo de minhas atividades docentes, o que possibilitou a dedicação exclusiva ao curso de Doutorado.

A Deus, pela vida, pelo que sou e por tudo que tenho. 


\section{RESUMO}

Esta tese efetua uma leitura comparada das obras Percursos (Do Luachimo ao Luena), publicada em 1981, pela portuguesa Wanda Ramos (1948 1998), e O Berro do Cordeiro em Nova York, escrita em 1995 pela mato-grossense Tereza Albues (1936 - 2004), focalizando a memória enquanto elemento estético literário organizador da narrativa, cuja gênese está ligada ao ato de recordar as experiências de vida pela personagem principal a partir das relações sociais, constituídas durante todo o percurso de sua existência e, de modo especial, no presente da narração. Ao tecer a própria história, o "eu" é sujeito e objeto da sua percepção e da abordagem discursiva. Ao rememorar e construir sua história de vida sempre à luz do ficcional, as protagonistas atribuem uma espécie de unidade ao "eu" textual que se distingue do "eu" da experiência, descontínuo e fragmentado pela infinitude da existência em oposição ao mundo finito, fixado através da linguagem escrita; pela vulnerabilidade do vivido, impossível de ser apreendido pelo sujeito na totalidade, e pela fragmentação do ser em constante mobilidade. A rememoração no ato criador das duas narrativas literárias mencionadas vem acompanhada do imaginário ficcional, capaz de preencher as lacunas provocadas pelo esquecimento e pela limitação da percepção e da apreensão do vivido pelas protagonistas. Por considerar $\mathrm{o}$ ato de lembrar intrinsecamente ligado às relações interpessoais, a memória como uma habilidade psicológica do ser humano, que depende dos signos para se fazer expressar e que os signos possuem significados constituídos socialmente, o suporte teórico desse trabalho é norteado pelos estudos de Halbwachs e de Bakhtin, acrescidos das abordagens de Walter Benjamin referentes à habilidade de narrar como uma das peculiaridades fundamentais do ser humano intimamente ligada ao processo mnemônico. Este estudo nos leva a entender que a formação das protagonistas revelada, construída e apresentada no final dos textos por meio do discurso metalingüístico está entrelaçada às próprias "escrituras do eu", tendo como ápice desse processo a autonomia da obra de arte em relação a seu criador.

Palavras-chave: Memórias; Escrituras do eu; Wanda Ramos; Tereza Albues. 


\section{ABSTRACT}

This paper aims at reading comparatively the works Percursos (Do Luachimo ao Luena) (1981) by Portuguese writer Wanda Ramos (1948-1998), and $O$ Berro do Cordeiro em Nova York, (1995) written by Tereza Albues (1936-2004) and born in Mato Grosso - Brazil. It will be focused the memory while aesthetic literary organizer element of the narrative, whose genesis is linked to the act of remembering life experiences by the main character from social relations constituted during the whole course of his existence and, in a special way, in the present of narration. By writing the own history, the "self" is subject and object of his perception and discursive approach. In the exerecise of remembering and constructing their life history, always through the fictitious light, the leading characters of these works attribute a species of unity to the textual "self" that distinguishes itself from experience "self", discontinued and fragmented by the existence infinitude in opposition to the finite world, fixed through written language; by voluntarity of the vivid, impossible of being carried off by the subject on its totality, and by the fragmentation of being in constant mobility. The remembrance at creative act of the two literary narratives mentioned above comes along with fictional imaginary, capable of filling the gaps provoked by forgetfulness and limitation of perception and the apprehension of the vivid by the leading characters. By considering the act of remembering intrinsically linked to the interpersonal relations, memory as a psychological skill of the human being, which depends on the signs to express itself and that the signs own meanings socially constituted, the theoretical support of this paper is based on the studies of Halbwachs and Bakhtin, added by the approaches of Walter Benjamin concerning the ability of narrating as one of the fundamental peculiarities of the human being closely linked to the mnemonics process. This study leads us to understand that the leading characters formation revealed, constructed and presented in the end of the texts by means of metalinguistical discourse is interlaced to the own "writings of the self", having as the climax of this process the fine art's autonomy in relation to its creator.

Key-words: memories, writings of the self, Wanda Ramos, Tereza Albues. 


\section{SUMÁRIO}

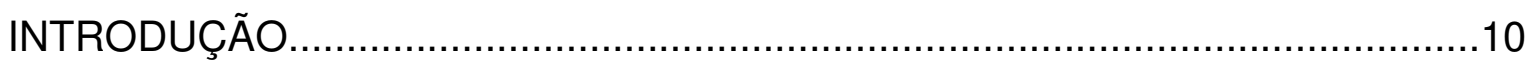

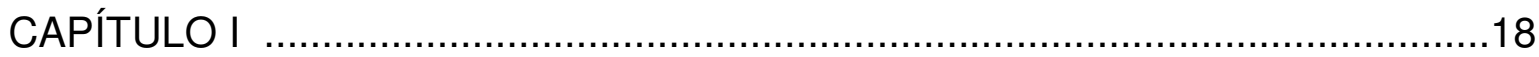

1. Memórias: "Escritura do eu" ............................................................18

1.1. Mnemósine e Cronos: uma parceria necessária....................................18

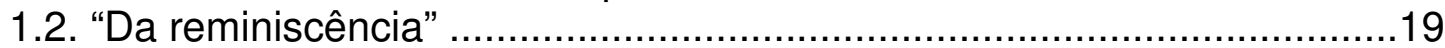

1.3. Dos apoios da memória à memória involuntária.....................................28

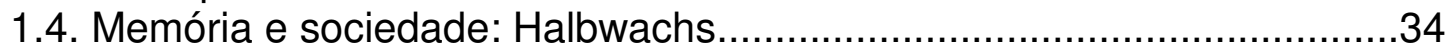

1.5. Do narrador experiente ao narrador ouvinte.......................................43

1.6. "As escrituras do eu" e os seus contornos...........................................49

1.7. Do romance ao Künstlerroman...........................................................58

1.8. Rememorar: do fluxo da consciência ao discurso indireto livre...............63

1.9. Subjetividade: relações dialógicas.....................................................67

1.10. Subjetividade e memória.....................................................................

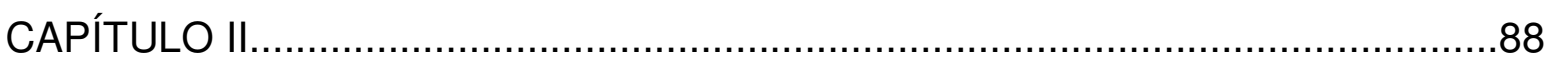

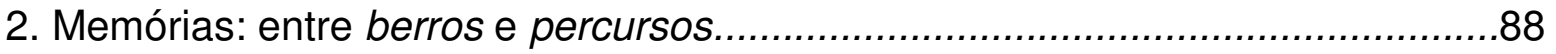

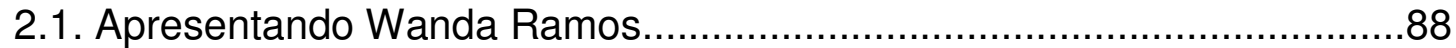

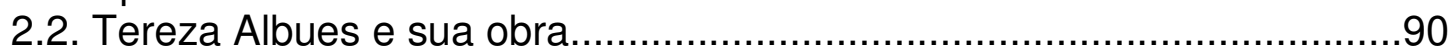

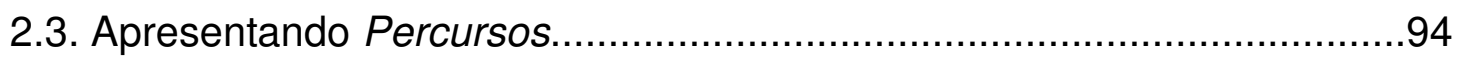

2.4. Percursos e a identidade portuguesa................................................103

2.5. Apresentado O berro do Cordeiro em Nova York................................111

2.6. Duas meninas em mundos "cindidos" ................................................115

2.7. A luz de um novo olhar, apesar da Guerra Colonial............................130

2.8. A infância através do entrecruzar de olhares.....................................132

2.9. Memória: vozes que se cruzam ......................................................136

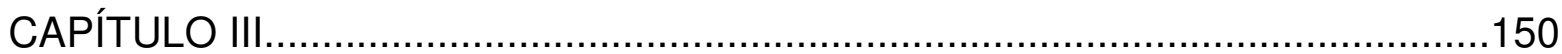

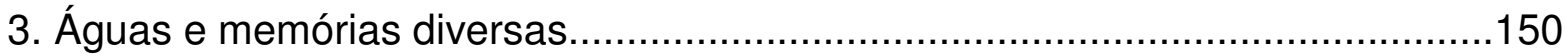

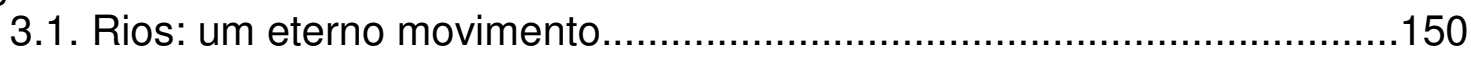

3.2. Rios e o encontro das águas........................................................157

3.3. Correntezas a pulsarem pela identidade do ser..................................161

3.4. Uma "viandante" a perambular pelo mundo........................................165

3.5. Um ovo a infiltrar-se ou um casulo a romper-se..................................172

3.6. O Voo....175

3.7. A Memória e o vermelho: "vir a ser" e sua gênese..................................180

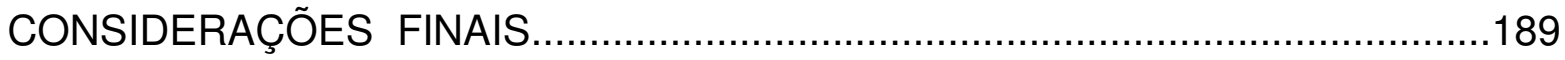

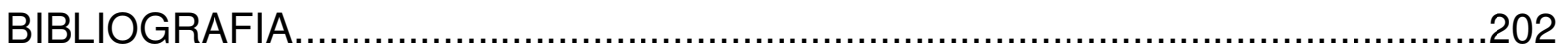

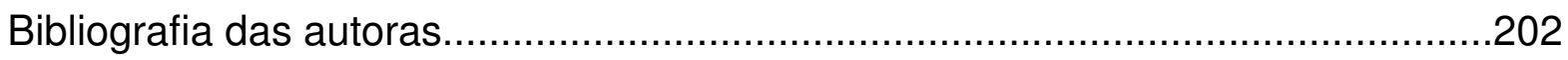

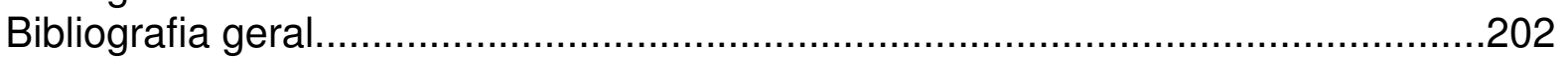




\section{INTRODUÇÃO}

Tanto na obra Percursos (Do Luachimo ao Luena) ${ }^{1}$ (1980), publicada pela portuguesa Wanda Ramos (1948 - 1998), quanto em O Berro do Cordeiro em Nova York ${ }^{2}$ (1995), de autoria da mato-grossense Tereza Albues (1936-2005), a protagonista rememora as experiências de vida ocorridas especialmente em dois espaços importantes, anunciados pelo título da narrativa. Na primeira, as ações da infância da personagem concentram-se no espaço definido pela presença do rio Luachimo e as experiências da personagem quando adulta estão situadas no espaço contemplado com a presença do rio Luena: "rios de Angola meu outro espaço" ( $P$, p.49). É assim que a personagem se refere à Angola em relação a Portugal, ao tratar de suas experiências de vida. Ambos os rios assinalam importantes espaços dos acontecimentos da narrativa acontecidos em Angola, local que se opõe espacial e temporalmente a Portugal, pouco abordado na narrativa de Wanda Ramos, silenciando quanto a maioria das ações alusivas ao processo da formação personagem situadas em Lisboa.

No caso da segunda obra, dois países constituem espaços díspares, onde estão situadas as principais ações da narrativa, Brasil (Cordeiro em Mato Grosso) e Estados Unidos (Nova York). A esses espaços correspondem também, como em Percursos, dois rios: o riacho do Cordeiro, ligado às experiências de menina da personagem, e o rio Hudson, onde se situam as principais ações da vida adulta da protagonista, o espaço e o tempo da narração.

Os espaços referidos são acionados pela memória que, no estudo que realizamos, é focalizada enquanto um elemento estético-literário, fruto da rememoração, muitas vezes, involuntária, de um sujeito que recorda suas experiências de vida a partir das relações sociais constituídas durante todo o percurso de sua existência e, especialmente, a partir daquelas estabelecidas com a realidade social do presente da narração. No propósito de construir a própria história, o "eu" é sujeito e objeto da sua percepção e narração coincidentemente.

\footnotetext{
${ }^{1}$ Doravante referida como Percursos.

2 Referida, a partir daqui, como O Berro.
} 
Considera-se, ainda, que ao rememorar e tecer sua história de vida, sempre à luz do ficcional, as protagonistas atribuem uma espécie de unidade ao "eu" textual, que se distingue do "eu" da experiência, descontínuo e fragmentado pela infinitude da existência em oposição ao mundo finito, fixado por meio da linguagem escrita, pela vulnerabilidade do vivido, impossível de ser apreendido pelo sujeito na totalidade, e pela fragmentação do ser, consonante com os paradigmas do mundo atual. Nesse sentido, ambas as narrativas analisadas apresentam os descompassos da vida moderna, marcada pela descontinuidade dos trajetos de vida, pelo deslocamento constante das pessoas, pelas mudanças rápidas ocorridas no espaço físico e social, na forma de vida cotidiana e nas relações interpessoais que tornam estranhos, para as pessoas, os lugares, os hábitos e os costumes já assimilados e familiares, e também pela diluição das fronteiras no que diz respeito às questões de nacionalidade e da construção identitária de cada ser, instituída na relação dialógica entre o "eu" e o "outro" que, a cada novo momento, ganha maior velocidade na transformação do sujeito atual. Mas o movimento que os romances de Albues e Ramos realizam, segundo nossa tese, transforma a rememoração no ato criador, capaz de preencher as lacunas provocadas pelo esquecimento e pela limitação da percepção e apreensão do vivido pelo sujeito, representado nos textos analisados pela personagem principal: em Percursos, pelo narrador em terceira pessoa e, em $O$ Berro, pela narradora-protagonista, que conta os acontecimentos em primeira pessoa.

Por se considerar nesta pesquisa que 0 ato de lembrar está intrinsecamente ligado às relações interpessoais, que a memória depende dos signos para se fazer expressar e que os signos possuem significados constituídos socialmente, o suporte teórico deste trabalho será norteado, sobretudo, pelos estudos de Halbwachs e de Bakhtin, acrescidos das abordagens de Walter Benjamin, referentes à habilidade de narrar como uma das peculiaridades fundamentais do ser humano, e de Proust, sobre a memória involuntária.

Ao realizarmos uma leitura comparativa entre as duas obras, demos ênfase à oposição entre os lugares sociais ocupados pelas protagonistas das narrativas: enquanto na obra portuguesa a personagem é uma menina branca no meio de negros, na obra mato-grossense é uma menina negra a transitar no meio de brancos. Segundo nossa perspectiva, não se trata apenas de uma questão de diferença de cor, já que o contexto que cerca essas personagens é extremamente 
importante. A primeira é filha de portugueses residentes em Angola a serviço do colonialismo português, com o pai exercendo o papel de funcionário na Diamang ${ }^{3}$. Os acontecimentos narrados têm como pano de fundo momentos relevantes da história de Angola e de Portugal: o declínio do colonialismo, a Guerra Colonial (1961-1974) e, consequentemente, o fim do Império português. Trata-se de fatos que repercutem na reconfiguração identitária tanto do ser português quanto da nação portuguesa, constituindo, assim, um momento de transição. Já a segunda personagem, a da obra mato-grossense, cuja origem dos pais é caracterizada pela mistura de diversas descendências étnicas, é criada numa realidade em que ser branca ou ser negra define em muito o seu papel e a sua importância na sociedade de que faz parte, já que a vida humana se estabelece num espaço sociocultural em que a lei do Estado, da Igreja e da família sempre favorecem os que estão no topo da pirâmide social. A tecedura do enredo de $O$ berro está alinhavada ao contexto histórico e social de Mato Grosso, cujo perfil parece drasticamente distinto do contexto histórico de Nova York, do presente da personagem-narradora.

Além de ponderar sobre o contexto social e histórico em que se situa o enredo das obras estudadas, é importante averiguar como se processou, nos últimos anos, a recepção das "escritas do eu". Sabe-se que, a partir das últimas décadas do século $X X$ e princípio do século $X X I$, a crítica literária tem conferido maior atenção às escritas da subjetividade. Constata-se, nos últimos decênios, um desejo acentuado, por parte de quem escreve, de objetivar a sua própria existência por meio da rememoração. No Brasil, Antonio Candido (1976), já na década de setenta, aponta que o contexto vivenciado pela produção literária favorecia o surgimento de um número considerável de obras de memória. Assim, as "escrituras do eu"4 já começavam a ser investigadas pela crítica desde aquele momento, contando, ainda, com muitas publicações e eventos nas últimas três décadas, referentes à literatura de memória como, por exemplo, os seis densos volumes das memórias de Pedro Nava. Em contrapartida, a literatura de memória portuguesa, por

\footnotetext{
3 Diamang significa Companhia de Diamantes de Angola. Em 1917, começa em Angola a extração do diamante e em 1916 surge a Dimang, é uma empresa de capitais mistos, que emvolvia grupos financeiros de Portuga, África do Sul, Estados Unidos, Bélgica e Inglaterra. Mas em 1981, os angolanos passaram a ter um controle total da extração do diamante em seu País e transformam na Endiama - Empresa Nacionas de Diamantes.

4 "Escrituras do eu" é uma expressão utilizada por Georges Gusdorf como título de um de seus livros (Les escritures du moi), o qual versa sobre autobiografia, diários e memórias.
} 
falta de mais atenção da crítica, revela-se ao público leitor com certa timidez em relação à demanda das demais abordagens literárias produzidas em Portugal. Em 1992, a pesquisadora Clara Rocha publica um livro em que realiza a leitura de diversas produções autobiográficas, preocupada em convencer o leitor português a atentar para a diversidade da literatura autobiográfica naquele país, rompendo com o preconceito "de que a tradição portuguesa nesse domínio é relativamente pobre" (ROCHA, 1992, p.5). A crítica ressalta que há ainda um vasto campo a ser explorado da "escrita do eu", quando se leva em consideração os substanciosos estudos efetuados na França e nos Estados Unidos sobre o tema em questão.

A partir das chaves de leitura propostas para a comparação das duas obras, Percursos e $O$ berro, e da tese que formulamos quanto ao papel do ato criador, capaz de preencher as lacunas provocadas pelo esquecimento e pela limitação da percepção e apreensão do vivido pelo sujeito, dividimos o presente trabalho em três capítulos, seguidos das considerações finais. O primeiro capítulo, "Memórias: "escrituras do eu" traz a abordagem teórica que subsidia o estudo desenvolvido nesta pesquisa. O segundo e terceiro capítulos - "Memória: entre berros e percursos" e "Águas e memória diversas" - apresentam o estudo comparado de Percursos e $O$ berro, desenvolvendo o objeto proposto por esta pesquisa. Posteriormente, as Considerações finais apresentam o resultado da leitura comparada das narrativas.

O apoio teórico desenvolvido no primeiro capítulo, que dará suporte ao estudo efetuado, tem como alvo a memória enquanto um elemento literário norteador do processo criativo das obras Percursos e $O$ berro, fundamental na constituição identitária do homem, cuja existência no mundo moderno está firmada numa realidade sociocultural de natureza fragmentária. Por ser a infância o período da existência das protagonistas que recebe maior força estético-literária nas narrativas em estudo, considerando a simplicidade e o encantamento como elementos balizadores do olhar infantil que permeiam a visão experiente do adulto que narra, demos especial antenção à perspectiva da criança no que diz respeito ao processo de rememoração, à luz das ponderações de Halbwachs e de Gaston Bachelard. Na busca de entender a memória como uma habilidade psicológica desenvolvida socialmente, os textos $A$ memória coletiva e Los marcos sociales de la memória (Os quadros sociais da memória), de Halbwachs, para quem o ato de lembrar se constitui a partir das relações sociais estabelecidas pelo sujeito, 
balizaram este percurso teórico. Por considerar não apenas o aspecto social da memória, mas também toda a complexidade do ato de lembrar no consciente e inconsciente do sujeito ao interpretar seu passado, especialmente por meio do fazer literário, a abordagem sobre a memória involuntária - desenvolvida na narrativa de Proust e abordada por alguns de seus intérpretes - adquire fundamental importância para a análise de diversos aspectos das narrativas envolvidas nesta pesquisa no que diz respeito ao processo de rememoração.

No que concerne ao romance enquanto artefato, especial destaque será dado à figura do narrador, centrada na sua própria experiência, concebida como elemento essencial no processo de construção da narrativa. O estudo do texto "O narrador", de Walter Benjamin, será o ponto de partida para uma ponderação no sentido de conhecer e discernir os caminhos trilhados pelos narradores das duas obras. Levando em conta a aridez do contexto sociocultural contemporâneo ao desempenho da memória e da experiência no cenário do mundo atual, a abordagem de Benjamin, acompanhada de diferentes estudos de sua pesquisadora, Jeanne Marie Gagnebin, sobre a memória e os papéis exercidos pelo narrador, será de grande importância para a efetivação analítica desta pesquisa. Para que a análise do narrador em primeira pessoa (no caso da obra, com traços de natureza autobiográfica) possa adquirir maior consistência, faz-se necessário, ainda, compreender a questão da subjetividade, a qual constitui um traço fundamental da narrativa de teor intimista e também por ser a subjetividade um dos elementos característicos da concepção de mundo e de homem do sujeito contemporâneo. Por considerar que o passado nunca vem à tona de forma pura, é sempre interpretado por aquele que lembra em conformidade com o presente da narração, constituído pelas relações sociais, e também pelo fato de entender que o ser humano está em constante transformação a cada experiência vivida, deve-se levar em conta nesta pesquisa que a subjetividade se constitui na relação dialógica entre o "eu" e o "outro", usando como fundamento, neste caso, novamente, os estudos bakhtinianos. Diante da valorização do texto de teor autobiográfico e memorialístico, que traz em sua essência a substituição do herói (único sujeito) pelos sujeitos múltiplos, da "Verdade" (difícil de ser sustentada), pelas várias verdades subjetivas, faz-se necessário acrescentar ainda o estudo da argentina Beatriz Sarlo, o qual permite ao leitor melhor compreender a ideia de subjetividade, que permeia as "escrituras do 
eu", se levarmos em conta a constituição da unidade identitária do sujeito textual através da tessitura da própria narrativa de sua história de vida.

Se a narrativa centrada no "eu" contribui para a autoafirmação do sujeito e o leva a constituir-se enquanto unidade, o que contraria a ideia de fragmentação do ser, é relevante que se reflita sobre as questões sociais, políticas e culturais que favorecem essa fragmentação do "eu" a partir das abordagens de Stuart Hall, fundador dos Estudos Culturais, para quem homem contemporâneo, em decorrência da diversidade de acontecimentos que interferem em seu percurso de vida, da rapidez com que a realidade atual se transforma à sua volta, da facilidade com que as culturas se misturam em decorrência não só dos problemas sociais, econômicos e políticos das nações, mas também do processo rápido de desenvolvimento tecnológico dos meios de comunicação e de transporte, sente dificuldade em constituir-se enquanto sujeito e construir a sua identidade. As mudanças estruturais fragmentam e deslocam as identidades culturais no que diz respeito à etnia, à nacionalidade, à classe social e até à sexualidade. A ideia de um sujeito fragmentado, múltiplo e indefinido é discernido por Bakhtin ao tratar da subjetividade. A fragmentação e multiplicidade do "eu", neste caso, não se dá como fruto de um acontecimento negativo do mundo globalizado, mas como algo que pertence à natureza humana, caracterizada como contraditória e instável. O sujeito de pronto, definido e acabado - passa a ser concebido como um contínuo "vir a ser". O "eu" não é apenas um ser em constante modificação como consequência das mudanças repentinas das estruturas, mas ele passa a ser concebido como um ser em construção, indeterminado. Essencialmente, é a concepção do sujeito que muda: aquele "eu" completo, estável, passa a ser observado como inacabado e infinito. Para melhor entender as repercussões do mundo globalizado na questão da constituição identitária do homem atual, por meio do estudo crítico das protagonistas de Tereza Albues e de Wanda Ramos, também lançaremos mão das ponderações de Eric Hobsbawn.

De acordo com essa atenuação das fronteiras na definição do "eu", o gênero em que as narrativas foram constituídas passa também pela diluição das fronteiras, pois oscila sempre entre dois polos: autobiografia/romance, memória/ficção e realidade/imaginação. O próprio romance já é um gênero essencialmente híbrido. Assim sendo, Bakhtin mais uma vez nos iluminará nesta 
empreitada teórica não apenas na compreensão do gênero romance, mas também no estudo da natureza do texto autobiográfico. Mas o principal norteador na abordagem da questão da autobiografia será o francês Philippe Lejeune, que há anos vem pesquisando os escritos do eu.

Pautado na questão da verossimilhança interna da obra, conceito tratado por Aristóteles, Antonio Candido dará subsídio para que se compreenda a relação estabelecida entre o ficcional e o autobiográfico nas narrativas estudadas. Para o crítico, o ficcional se opõe ao "caos da vida", pois tanto os personagens quanto os demais elementos que constituem a narrativa se entretecem e se organizam conforme leis próprias da obra, definidas internamente. O mundo fictício das obras se apresenta de forma mais nítida, com contornos mais definidos que a pessoa real.

O segundo capítulo desta pesquisa realiza a apresentação das autoras Wanda Ramos e Tereza Albues buscando, de certa maneira, aproximar os vários pontos em comum na trajetória de vida das autoras: ambas passaram por um processo de reconfiguração identitária, inserido no contexto de transformações socioculturais e políticas de seu país e também do mundo, especialmente, no caso da escritora mato-grossense. Na apresentação das obras analisadas, fica evidente que ao entretecerem os fios de memória puxados de suas histórias de vida, as protagonistas dão às narrativas uma textura que simula o próprio funcionamento da memória. A questão da tessitura das obras, por trazer o aspecto da fragmentação e do descontínuo na estrutura do texto de Percursos e, em especial, de $O$ Berro, sendo que este texto ainda conta com o recurso narrativo do fluxo da consciência, coloca-se em sintonia com a mobilidade do eu na relação com o outro e a multiplicidade de vozes manifestas e filtradas pela voz das personagens principais.

O terceiro capítulo dá continuidade à análise comparada das duas obras pesquisadas, mas de modo a se ater de maneira detalhada a algumas imagens simbólicas que dão ao texto maior profundidade na abordagem da questão das personagens como seres em trânsito. A imagem da água e do rio, cuja rede de sentidos está vinculada às várias possibilidades de mudanças ocorridas no mundo, nas pessoas e nas coisas, relaciona-se ao trajeto das personagens a rememorar 0 passado, o qual revela uma condição de vida caracterizada pelo deslocamento e pela viagem por diversos espaços. Nos dois textos, a presença do rio demarca os dois cronotopos que situam as principais experiências lembradas e narradas. A 
imagem do curso do rio, associada ao curso da memória enquanto fluxo no processo narrativo e ao do vir a ser - no sentido de estar ligado também à passagem do tempo -, consta nas duas narrativas, mas recebe maior enfoque no texto de Wanda Ramos, até porque o subtítulo da obra é formado pelo nome dos dois rios (Do Luachimo ao Luena). E a ação de voar, abordada numa linguagem figurada pela narradora de Albues e numa linguagem direta na narrativa de Wanda Ramos, pode recuperar, na perspectiva desta pesquisa, o mito de Ícaro no que diz respeito metaforicamente ao equilíbrio a ser mantido entre o novo da transformação e o velho do já configurado, tanto em relação à formação das protagonistas quanto à organização estética da narrativa cunhada nos recursos mnemônicos. Reforçado pela ideia de nascimento e metamorfose, expressa em $O$ berro, examinam-se outras imagens: o ovo, que permite a infiltração da casca, e o casulo a romper-se em borboleta, bem como o complexo simbólico de sentidos da cor vermelha, relacionada às fases de mudança na vida da personagem, assinalam os diversos nascimentos simbólicos da protagonista, aos quais se relaciona o corte ou não do cordão umbilical por três vezes na narrativa.

As "Considerações finais" do trabalho se aterão às abordagens de natureza metalinguística nas duas narrativas. No final dos dois textos, determinadas imagens apresentadas sugerem o desenvolvimento da autonomia da obra em relação a seu criador e, assim, as narrativas literárias em questão, cunhadas na rememoração, acompanhadas do imaginário, ao estabelecerem relações dialógicas com outras produções textuais de várias formas de linguagens, buscam inserir-se na tradição literária cultural ocidental. O sentido das obras constituídas a partir das lembranças do "eu", as quais versam sobre o indivíduo na sua subjetividade, só vai ganhar totalidade e completude na inserção dos referidos textos num todo maior, configurado pelas demais produções artísticas. 


\section{CAPÍTULO I}

\section{MEMÓRIAS: "ESCRITURAS DO EU"}

\subsection{Mnemósine e Cronos: uma parceria necessária}

Contar é narrar e contar é
numerar. Contar o que
aconteceu exige que se digam
o ano, o mês, o dia, a hora em
que o fato se deu. O ato de
contar paga tributo ao deus
Cronos.

Alfredo Bosi

Para ilustrar e melhor compreender a concepção de memória nos quadros da cultura ocidental, em que estão inseridas as duas obras em estudo - Percursos (Do Luachimo ao Luena), de Wanda Ramos, e O berro do Cordeiro em Nova York, de Tereza Albues - faz-se necessário que se recorra ao mito de Mnemósine, deusa da memória que é uma titânica irmã de Cronos, deus do tempo.

No contexto cultural da Antiguidade Grega, Mnemósine, filha de Urano e Gaia, ocupa um lugar privilegiado na tradição mítica, pois se trata de uma titânica relacionada às origens do universo. Farta do permanente abraço de seu esposo, Urano (Céu), constantemente a gerar-Ihe vidas, Gaia (Terra) pede ajuda a seus filhos, os quais se recusam, com exceção do filho mais novo, Cronos (deus do tempo) que, por meio de uma emboscada, decepa os testículos do pai.

Como se pode ver, é a personificação do tempo (Cronos) que vai destruir o poder de Urano, seu pai, e, numa atitude ardilosa, ocupar o seu lugar. Todo o referencial de sentidos que emana dessa passagem simbólica da história de Cronos expressa, de certa maneira, o que a passagem do tempo representa no percurso da 
existência humana. Cronos sempre teve, como estratégia para se manter no poder, a prática de devorar os próprios filhos.

Zeus, um dos filhos de Cronos, protegido pela mãe de ser devorado pelo pai, derrota-o, isto é, vence o Tempo, e ganha uma batalha em favor da imortalidade. Para celebrar sua vitória sobre os Titãs, Zeus se une à Mnemósine, única titânica protegida por ele de ser mandada para o Tártaro, como aconteceram com seus iguais, com a qual gerou nove musas, inspiradoras das várias artes e áreas do saber: Calíope (poesia épica), Clio, (história ) Erato (poesia Lírica), Euterpe (música), Melpômene (tragédia), Polímnia (música cerimonial, sacra), Terpsícore (dança), Tália (comédia), e Urania (astronomia). Segundo Emanuel Carneiro Leão, "Mnemósine é, então, a memória geradora, que se tornou no jogo do amor, a mãe de todas as forças criadoras da condição humana, as musas" (2003, p. 146).

Além de ser a Memória a mãe das artes e de importantes áreas do saber humano, ela é irmã do deus Tempo, o que assinala a importância do significado simbólico da relação existente entre esses dois elementos essenciais na constituição da existência humana. São elementos contraditórios, mas interdependentes na constituição da cultura da humanidade e na construção identitária de cada nação, comunidade e especialmente de cada sujeito enquanto componente de uma coletividade.

$O$ ato de lembrar exige que o tempo se estabeleça, pois só se pode recordar de algo que já se passou. Em contrapartida, se de um lado o tempo tudo constrói, é graças a ele que até o que há de mais sólido se esvai, ou melhor, transforma-se. Daí vem a importância da representação simbólica estabelecida pela atitude do deus Cronos de devorar os próprios filhos.

Referir-se ao passado é, no entanto, algo complexo e denso. Para Beatriz Sarlo, o passado sempre foi visto como um espaço de conflito entre a memória e a história. Se de um lado a história discorda da memória, de outro, esta "desconfia de uma reconstituição que não coloque em seu centro os direitos da lembrança (direitos de vida, de justiça, de subjetividade)" (SARLO, 2007, p. 9). Se a subjetividade é algo peculiar à lembrança, a relação com o passado muitas vezes não depende da vontade e da astúcia do sujeito. Para a pesquisadora, a volta ao passado nem sempre se configura como um acontecimento libertador da lembrança, mas um evento em que há a "captura desse passado pelo presente. Dentro da visão 
halbwachsiana, a expressão "captura desse passado" remete, certamente, a uma concepção de que o passado possa ser recuperado por meio da memória de forma intacta e pura. É necessário, então, que saiamos dessa esfera do individual para a do coletivo: o sujeito só retoma o passado conforme sua visão consubstanciada no presente, que se define palas relações sociais, estabelecidas pelo sujeito durante toda sua existência. Aquele que lembra o faz de maneira interpretativa, conforme sua visão de mundo constituída ao longo da vida.

Os acontecimentos dos últimos tempos, para Sarlo, deram-nos a impressão de que o passado perde sua importância perante o presente; no entanto, o passado nunca fora tão visitado como nas últimas décadas através dos mais diversos meios como: museus, filmes, novelas, romances históricos, histórias da vida privada e demais instrumentos que fazem do passado um espetáculo. Assim, a existência das narrativas analisadas nesta pesquisa faz parte dessa tendência das pessoas voltarem suas atenções para as experiências do passado, mesmo nesse contexto, em que, como afirma Walter Benjamin, as experiências estão em baixa e a arte de narrar em extinção.

Observa-se que as diversas visões do passado são construções discursivas, permeadas pelas ideologias daqueles que a expressam. Além da perspectiva preservacionista e celebrativa, o passado passa a ser apresentado não por meio de uma modalidade acadêmica, mas por meio de relatos de outras formas de discursos, provenientes da atividade narrativa desenvolvida pelas pessoas comuns na recriação de suas experiências quotidianas.

O olhar do historiador e dos cientistas sociais deslocou-se dos registros dos fatos, classificados como importantes, para as histórias do cotidiano, envolvendo, assim, personagens que antes eram colocados à margem. A mudança de foco dos pesquisadores e intelectuais da história e da sociedade como um todo faz com que os pequenos detalhes, certas curiosidades, as exceções à regra antes esquecidos em prol dos grandes feitos - ganhem relevâncias nas abordagens. Os "sujeitos marginais, que teriam sido relativamente ignorados em outros modos de narração do passado, demandam novas exigências de métodos e tendem à escuta sistemática dos 'discurso da memória': diários, cartas, conselhos, orações" (SARLO, 2007, p. 17). É possível acrescentar a essa enumerarão outros vários gêneros literários que trazem na sua constituição, como elementar, a memória e o 
quotidiano das pessoas, como o romance de formação, o romance do artista, a autobiografia, a biografia, o romance de testemunho e a obra de memória.

$\mathrm{O}$ ato de lembrar é uma forma de resistir às transformações causadas pelo tempo, e a arte literária seria uma forma de salvação uma forma de "recuperar o tempo perdido", como afirma Proust ao nomear sua obra. Seria, então, a escrita literária de memória um meio de ultrapassar as fissuras abertas pela existência pelo tempo.

Ao conceber a arte como um meio utilizado pelo homem para driblar o poder corrosivo do tempo, faz-se necessário, neste momento, refletir sobre as observações tecidas por Bakhtin. Para ele, as grandes obras são aquelas capazes de ultrapassar as fronteiras de sua época para se lançarem no "grande tempo", isto é, perduram ao longo dos séculos rumo ao "eterno". Ao tratar da complexidade que há em adotar um único método de estudo do fenômeno literário, Bakhtin aborda a importância que há no afastamento no tempo do fenômeno estudado. Em contraposição, a passagem do tempo neste sentido adquire uma conotação positiva, pois o afastamento no tempo pelo leitor crítico da obra lhe possibilita uma visão mais ampla e profunda. Para que uma obra seja inserida no "grande tempo", ou seja, para que ela perdure no futuro ao longo dos séculos, é necessário que ela tenha lançado suas raízes em um passado distante e esta é a principal razão, pela qual a interpretação de uma obra exige que se vá além de sua época de produção: para se penetrar "nas profundezas dos sentidos" de uma obra é preciso que o crítico a analise para além das condições culturais de sua época imediata (BAKHTIN, 2006, p. 360-366).

Deste modo, os estudos literários devem estabelecer um estreito vínculo com a história da cultura. A literatura para ser entendida na sua densidade e profundidade necessita ser abordada como parte integrante de um contexto pleno, envolvendo assim o conhecimento de toda a cultura expressa, que por uma ou outra razão esteja relacionada ao texto em análise. Como a riqueza de sentido de uma obra transborda o imediato, é imprescindível que se avalie e se conheça também o contexto sóciocultural não só de uma época, mas sim de todas as outras épocas que, de alguma forma, tenham ligação com a obra em estudo. Os fenômenos semânticos, ao mesmo tempo que preexistem à produção da obra de arte, aparece também "em forma latente" isto é em potencial, à espera de serem ativados pelos sujeitos de outros momentos futuros à sua criação. Para o "escritor- 
artesão", os gêneros da literatura e do discurso - cujo significado fora acumulado ao longo da tradição, conforme as diversas formas de concepção de mundo constituídas - servem-lhe como uma espécie de "chavão externo", mas para o grande artista funciona como um impulso à fecundidade de sua capacidade criadora. Pois o artista é capaz de dar, a essa forma fixa e padronizada dos gêneros, determinada mobilidade e despertar os sentidos latentes, neles impregnados ao longo dos séculos. Tratando desta questão do afastamento do sujeito em relação ao texto analisado como algo importante para que se visualizem sentidos nunca antes percebidos em uma obra, Bakhtin ressalta que o autor e seus contemporâneos estão, muitas vezes, aprisionados em seu tempo por se aterem apenas ao contexto próximo de seu presente. "Os tempos posteriores o libertam dessa prisão, e os estudos literários têm a incumbência de ajudá-lo nessa libertação". (Ibidem, p. 364). Em defesa dessa abrangência temporal mais ampla em relação aos estudos literários, Bakhtin alerta que "tudo o que pertence apenas ao presente morre junto com ele" (Ibidem).

Em síntese, a obra de arte para se fazer presente e valiosa necessita não só de sua entidade maior Mnemósine que representa a memória, mas especialmente o tempo, isto é, o afastamento no tempo da obra avaliada. O tempo, da mesma forma que se remete à questão do esquecimento, está diretamente relacionado à ação de lembrar, o que permite ao leitor uma apreciação mais rica e ampla dos textos.

\section{2. "Da reminiscência"}

A compreensão do conceito de memória, pelo viés do texto literário, requer uma reflexão sobre o termo reminiscências, muitas vezes, utilizado como sinônimo de memória. Em sentido geral, reminiscência refere-se à retomada de uma lembrança, da qual o sujeito não tem consciência. Pode-se, então, encontrar em um texto, numa obra de arte passagens ou traços de outras produções já construídas anteriormente. Assim, reminiscência expressa o processo da tradição, em especial da tradição literária, e da própria cultura, que passa de geração em geração. Em sentido comum, o termo reminiscência refere-se a lembranças ofuscadas pelo tempo, a uma recordação vaga, a fragmentos de algo que não exista 
mais, a restos, sobejos de um passado distante que nos restam na lembrança, dando assim a idéia de algo que nos vem da memória de modo incompleto.

A narrativa de Wanda Ramos se constitui de quarenta e seis capítulos, intitulados de "reminiscência", sendo essa palavra precedida pelo numeral correspondente a ordem temporal aproximada dos acontecimentos narrados ("Primeira reminiscência", "Segunda reminiscência", "Terceira reminiscência", etc.), dispostos na obra de maneira não muito ordenada, pois há passagens em que determinada "reminiscência" de numeração e ordem temporal pertencente, por exemplo, ao final da narrativa que aparece encaixada na parte inicial do texto(ou o contrário), para complementar a abordagem de um assunto tratado. Em O berro, a narradora de Tereza Albues não se refere ao conceito reminiscência com freqüência, como o faz a escritora portuguesa, mas o apresenta de forma diluída durante 0 percurso da sua narrativa. Reminiscência designa um tipo de lembrança que insiste teimosamente em vir à tona na consciência, independente do desejo da personagem, como se observa nesta passagem: "Reminiscências dum estágio de vida que ainda insiste em permanecer grudadas à minha pele..." (BCN, p. 187). De acordo com a perspectiva da narradora-personagem, aquilo que passou por sua vida na infância e juventude (possivelmente pelas fortes emoções vivenciadas), deixou vestígios em sua personalidade, dos quais não consegue se desvencilhar por mais que se distancie e se transforme. $\mathrm{O}$ ato de rememorar é muitas vezes abordado no texto constituindo, especialmente, as passagens de natureza metalingüística. Passagens essas que evidenciam uma relação de identificação entre a autoranarradora-personagem.

Para uma compreensão mais significativa a respeito do que seja reminiscência é importante que se tenha em vista a abordagem de Walter Benjamim sobre este conceito. É graças à reminiscência que as histórias se entretecem, formando uma rede que as mantêm interligadas. As narrativas se articulam umas às outras:

a reminiscência funda a cadeia da tradição, que transmite os acontecimentos de geração em geração. Ela corresponde à musa épica no sentido mais amplo. Ela inclui todas as variedades da forma épica. Entre elas, encontra-se em primeiro lugar a encarnada pelo narrador ela tece a rede que em última instância todas as histórias constituem entre si. Uma se articula na outra, como demonstraram todos os outros narradores (1994, p. 210-211). 
O narrador de Benjamin não tem como finalidade repassar "o puro em si" daquilo que é narrado como uma informação ou mesmo como um relatório. $O$ narrador absorve para si "a coisa narrada", isto é, mergulha-a dentro de si e, ao contá-la, o faz de maneira a deixar na narrativa as marcas de sua experiência. Desse modo, "se imprime na narrativa a marca do narrador, como a mão do oleiro na argila do vaso" (Ibidem, p. 205). Assim, as histórias contadas apresentam vestígios tanto daqueles que as vivenciaram quanto daqueles que as relataram.

De acordo com Benjamin "A Imagem de Proust", ensaio escrito em 1929, para aquele que rememora, o importante não são as experiências que ele teve, mas como ele "tece" as rememorações daquilo que vivenciou. De acordo com essa perspectiva, Proust não descreve em sua obra a vida que viveu de fato, mas a vida que conseguiu lembrar. $\mathrm{O}$ acontecimento em si, para Benjamin, é dado como encerrado, finito no plano da realidade, mas o acontecimento na esfera do lembrado não apresenta limites "é uma chave para tudo que veio antes e depois". É a reminiscência que vai constituir as linhas mestras da organização do texto e a unidade deste "está apenas no actus purus da própria recordação, e não na pessoa do autor, e muito menos na ação" (1994, p. 37).

A magnitude da elasticidade ilimitada do evento, no domínio do lembrado e da urdidura textual, aparece ilustrada e esclarecida através de um fato verídico relacionado à vida de Proust, citado pelo filósofo frankfurdiano, em que o seu editor comenta o quanto seus hábitos de revisão deixavam os tipógrafos desnorteados, pois cada vez que Proust retomava seus escritos para corrigir, não o fazia, ocupava seu tempo e o espaço das margens das páginas impressas com acréscimos e novos escritos, detalhes inéditos a serem incorporados no corpo do texto a ser editado, numa maratona que parecia não ter fim. Essa dificuldade de Proust de chegar a uma versão final e conclusiva de sua obra demonstra bem essa abertura infinita que perpassa o ato de rememorar e a maneira de deixá-la inscrita no papel.

Ao tratar da natureza autobiográfica da obra, Benjamin compara Em busca do tempo perdido a "um Nilo da Linguagem, que transborda nas planícies da verdade para fertilizá-las" (1994, 36). Essa associação da imagem do rio Nilo a transbordar, encharcando e fertilizado as terras ribeirinhas, com a própria riqueza de sentidos, apresentada pela linguagem no processo de representação das reminiscências do narrador de Proust, corresponde a uma passagem em Percursos 
em que o narrador de Wanda Ramos descreve a cheia do rio Luachimo da seguinte forma:

Corria feroz ou manso o rio na periferia da vila, inchado na estação das chuvas (...) trespassando as margens, acordando os mitos antigos dos indígenas que manhã cedo traziam histórias novas (...) Assim ele cumpria uma de quantas funções o homem quis desde sempre atribuir-lhe, e redimia-se, ou condenavase, consoante a medida da fertilidade afinal propiciada (P p. 67)5.

A fertilização do solo ribeirinho pelas cheias do rio caudaloso a transbordar denota fertilização no terreno da linguagem em que o evento das cheias é capaz de provocar o surgimento de novas histórias e de trazer à tona antigas narrativas, deixadas no esquecimento há tempos pelas pessoas envolvidas no acontecimento referido. Utilizando de uma linguagem figurada e simbólica, podese afirmar que a força das cheias é capaz de vasculhar a memória dos indígenas deixando-os reminiscentes, capazes de desalojar imagens e histórias de eventos sepultadas pela distância temporal e pelas ocupações rotineiras dos moradores. Assim, a lembranças quando ativadas no processo de constituição da narrativa, saltam do inconsciente para o consciente do sujeito que rememora, com tanta força, que se assemelham ao jorrar das águas, em abundância, no leito de um rio em período de cheias. Referindo-se às memórias de Pedro Nava, Joaquim Aguiar pondera que, ao escrevê-las, o autor dá "a impressão de que, num certo momento, abriu as comportas de uma narrativa represada, de modo que tudo parece jorrar num jato vigoroso e único" (1998, p.18).

No livro de Tereza Albues, a figura do rio aparece de forma relevante, carregada de sentidos. Os rios que ganham destaque na narrativa são o rio Hudson, que equivale ao presente da narração, os rios do Pantanal de águas turvas, que estão relacionados ao tempo remoto da narrativa, versus o rio de águas claras do místico Benjamin Barbudo, um dos personagens mais importante na formação da protagonista.

Voltando à importância do significado do termo reminiscência, é relevante ressaltar que na acepção mítica, reminiscência estabelece a evocação do passado pelos homens, não pelos homens comuns, mas por aqueles envolvidos com as artes

\footnotetext{
5 A referencia das citações das obras analisadas será feita através das iniciais da obra seguidas da página utilizada: Percursos (Do Luachimo ao Luena): (P, p.....) e O Berro do Cordeiro em Nova York: ( BCN, p....).
} 
ou com as várias áreas do saber, graças ao poder das musas, pois são elas que contam aos homens como determinadas situações e fatos ocorreram. Assim, a capacidade de lembrar as experiências do passado não se caracteriza como um mérito humano, mas como algo pertencente ao poder divino das musas e da Mnemósine. Nesse sentido, a habilidade humana é avaliada na sua capacidade de evocar o poder das musas para concretização de seus propósitos. Platão, para descartar o entendimento mítico sobre memória, utiliza-se de sua habilidade literária, apoderando-se ou criando uma figura mítica, para explicar a teoria da reminiscência, o mito de Er6. A memória não é algo que está fora do homem, mas que faz parte deste, no sentido de levá-lo a relembrar o verdadeiro conhecimento, as verdadeiras idéias já contempladas pela sua alma antes de se tornar parte do mundo sensível. A reminiscência constitui, então, o reconhecimento do verdadeiro saber já contemplado pela alma no mundo das idéias. Se, para Platão, a memória ocupa papel central em relação ao conhecimento, para Aristóteles7, as impressões

\footnotetext{
${ }^{6}$ Em Platão, reminiscência refere-se à faculdade que o sujeito apresenta de retomar aquilo que foi contemplado pela alma em momentos anteriores, possibilitando-lhe uma visão direta do mundo das idéias. Na perspectiva do referido filósofo, a alma pré-existe ao corpo e sobrevive também ao fim deste. Antes de se encarnar em um ser, a alma teria se apoderado de todo o saber existente no mundo das idéias. Sendo assim, o conhecimento se constituía, para o referido filósofo, como relembrança. Já a ignorância residiria no ato do esquecimento. O saber seria, então, inato, algo a ser recordado. Se, na obra Mênon, reminiscência implica na imortalidade da alma, no livro Fedon tratase de um argumento a favor da imortalidade. $O$ que melhor esclarece a questão da reminiscência em Platão é a narrativa do "Mito de Er", um dos textos que compoe o livro X de $A$ República. Er era um pastor, "filho de Armênio, panfílio de origem" (595a - 621b), que morreu e foi levado para o reino dos mortos, onde se encontra com as almas de todos os heróis da Grécia, de comerciantes, de artistas, de seus amigos e de seus antepassados. Ali as almas têm contato direto com o conhecimento verdadeiro. Para retornar à terra e encarnar em um novo corpo, as almas realizam a travessia de uma grande planície, cortada pelo rio do esquecimento, o rio Lethé, e bebem de sua água. Antes de voltar à terra, as almas escolhem o tipo da nova vida que desejarão ter. De um lado, as almas que optam pela vida de comerciante rico, de guerreiro e de rei são as que mais se fartam das suas águas, de outro, as almas que escolhem a vida de sabedoria - como ser artista, filósofo e demais adeptos de outras áreas do saber - pouco bebem das águas do esquecimento. Assim, na nova vida, as primeiras pouco ou quase nada se lembrarão da verdade conhecida no mundo das idéias e as últimas serão portadoras da capacidade de lembrar e evocar o saber antes conhecido. Desse modo, o verdadeiro conhecimento da alma consiste na lembrança das Idéias verdadeiras (CHAUÍ, 2002, p. 60-70).
}

${ }^{7}$ Aristóteles dedica atenção especial à temática da memória, dedicando-lhe a abordagem de um dos
seus textos mais relevantes, "Da Memória e da Reminiscência", que compõem o livro Parva
Naturalia. Para Aristóteles, a memória propriamente dita (a mneme) se distingue de reminiscência (a
mamnesi). Enquanto a primeira se refere à habilidade do ser humano de conservar o passado, a
segunda é a faculdade de evocar voluntariamente o passado. Para este filósofo, o conhecimento se
dá com base nas sensações. O presente é o objeto das sensações, o futuro da esperança e da
opinião e o passado é visado pela memória. As percepções sensoriais antes de se tornarem elemento
constitutivo da faculdade intelectual são trabalhadas pela imaginação. Além de desempenhar o papel
de mediadora entre a percepção e o pensamento, a imaginação é também a parte da alma destinada
à criação de imagens mentais, com as quais os processos superiores do pensamento são
estabelecidos. Assim, não é possível imaginar algo que antes não tenha passado pelos sentidos. A 
sensoriais são a fonte para tal. Para se constituírem como pensamento intelectual, as impressões sensórias são tratadas pela imaginação, faculdade que ocupa o mesmo espaço que a memória na alma do homem. $O$ entendimento de que uma imagem mental não existe sem que antes tenha passado pelos sentidos e sido guardada pela memória torna as teorias de Aristóteles relevantes como subsídio para se pensar a estreita relação estabelecida entre memória e ficção. A escrita de um texto de memórias conta não apenas com as lembranças, mas também com a imaginação. Nesse sentido, é importante ressaltar que vários autores contemporâneos concebem a imaginação como uma grande parceria da memória no ato da criação literária, pois é o imaginário que dá verossimilhança ao texto e insufla o narrador a criar e inventar narrativas ou novas formas de contar o mesmo fato sob infinitos aspectos. Como este trabalho de pesquisa prima pela importância das relações sociais na constituição da memória do individuo, as idéias de Benjamin têm grande contribuição para o percurso teórico delineado neste item, pelo fato de o filósofo tratar a reminiscência como um elemento que permite as narrativas se entretecerem dentro do percurso da tradição literária.

Observa-se a dificuldade que há em definir reminiscência e o conceito de memória. Em síntese pode-se entender que memória, apesar de muitas vezes apresentar o mesmo significado que reminiscência, designa a capacidade do ser humano de capturar consciente ou inconscientemente todas as imagens e sensações do passado obtidas pelo sujeito, graças aos sentidos. Num entendimento próximo do que ponderou Aristóteles, a memória para exercer seu papel depende essencialmente das sensações. Seguindo nessa perspectiva a memória estaria ligada á capacidade de pensamento do homem, pois a atividade de pensar,de produzir idéias, isto é, raciocinar está intimamente relacionada com aquilo que se retém através da memória. Assim, memorizar, pensar e refletir são ações interdependentes, e a elas se vincula também a habilidade humana de imaginar, criar e ficcionalizar. Quando se pensa o termo reminiscência equivalendo ao

memória não é "nem a sensação nem a concepção do espírito, mas sim o estado ou a modificação de uma das duas, quando o tempo passa"(ARISTÓTELES, 1993, 449b). É através da memória que o homem desenvolve a noção do tempo. E o que há de mais importante é que tanto a memória quanto a imaginação pertencem à mesma parte da alma.

Reminiscência para Aristóteles não é nem a recuperação nem a aquisição da memória, mas uma faculdade humana em que não há apenas a permanência da imagem, mas sim o reconhecimento desta. A

reminiscência é então a memória consciente de si mesma. 
conceito de memória como faz Benjamin, chamando por Mnemósine (deusa da memória) como "deusa da reminiscência" dá a este um sentido amplo e profundo, pois é por meio das reminiscências que se processa a questão da tradição. Esse fato em que o conceito de reminiscência pode ser confundido com o conceito de memória ocorre tanto em Platão, para quem as reminiscências constituirão aquilo que o homem carnal poderá herdar do mundo das idéias, quanto para Benjamin, pois de acordo com sua abordagem é graças as reminiscências que a tradição é constituída. Assim, entende-se que através das reminiscências, todo o conhecimento do homem é desenvolvido ao longo da existência humana.

Já nas obras em estudo, $O$ berro e Percursos, o uso do termo "reminiscência" está diretamente relacionado ao ato de rememorar. São lembranças de um passado distante, muitas vezes, assinalados por fortes emoções, que vêm à tona entrecortado pelo esquecimento, provocado por determinados fatores, dentre eles a distância temporal. Desse modo, reminiscência dá a idéia de fragmentação do passado evocado. Evocação esta que independe da vontade do sujeito, refere-se, então, à "memória involuntária". Se há alguma unidade na narrativa no que se refere aos acontecimentos abordados, esta é atingida por meio da imaginação.

\subsection{Dos apoios da memória à memória involuntária}

Propor-se não lembrar é como se propor não perceber um cheiro porque lembrança, assim como o cheiro, acomete até mesmo quando não é evocada.

Beatriz Sarlo

Os objetos que povoam o espaço de convívio doméstico entre as pessoas Ihes servem de apoio à memória, contribuem para a constituição da identidade do sujeito à medida que expressam, através de suas peculiaridades, o estado e a posição social ocupados por seus donos. No passado, em tempos que precederam ao estilo de vida moderno, caracterizado pelo uso dos produtos descartáveis e pelo consumismo exacerbado, o amassado da caneca, o descascado do prato 
esmaltado, o "rustido" ou a asa quebrada da xícara de louça revelavam, não só a história de uso dos objetos, mas também a história do cotidiano das pessoas que os possuíam ou possuíram, enfim, a existência dos pertences do sujeito estava entranhada à sua própria existência nos âmbitos social, cultural e até psicológico. Daí que, o fato de adentrar a casa de alguém e observar cada espaço e objeto seu, configurar como uma atitude de intrusão, desrespeito à individualidade do outro, é como penetrar no interior, na intimidade, nas profundezas do "eu" dos seus moradores. Por isso existe, segundo Ecléa Bosi, o receio, muitas vezes, de transitarmos em casa alheia, pois quando o fazemos é como invadir a intimidade do outro e isso pode perturbar a ambos, tanto a "eu" quanto ao "outro".

Além dos objetos, há muitos outros elementos de apoio à memória, como o espaço e o ambiente. Depois de analisar as diversas histórias de vidas de velhos moradores de São Paulo, Ecléa Bosi pondera que a casa materna ocupa um lugar significativo na memória das pessoas. Mesmo se não for a primeira casa da qual se lembram, ela é o cenário das experiências mais ressonantes da infância.

A casa onde uma pessoa inicia sua existência e sua formação é, conforme o imaginário infantil, habitada por elementos valiosos do ponto de vista afetivo. Ao recordar, podem surgir "saudades de um objeto perdido de valor inestimável que, se fosse encontrado, traria de volta alguma qualidade da infância ou da juventude que se perdeu com ele" (BOSI, 1994, p. 442).

Quando se trata de memória de mulheres - as quais convivem mais intensamente que o homem com o espaço da casa, em decorrência de nossa cultura desenvolvida no bojo da sociedade patriarcal e constituída ao longo de milênios de anos - o espaço e o ambiente domésticos são uma constante em suas narrativas. A narradora de Teresa Albues descreve, com detalhe e proeminência, a maioria das residências por onde perambula a protagonista na infância e sua família. O espaço da casa do sítio do Cordeiro, o de sua primeira infância, é que se sobrepõe ao espaço da vida adulta da personagem-narradora. Em Wanda Ramos, a heroína observa o mundo, a divisão de classes sociais a partir da grande casa onde mora, cuja estrutura se destaca ante o visual de miséria característico do cenário a sua volta, especialmente da primeira parte da narrativa. Em outro sentido, o espaço externo de Percursos ganha relevância por ser representado no título da obra, especialmente pelos dois rios, Luachimo e Luena, em que cada um deles possue 
uma relação figurada com a memória da personagem a ser analisada no decorrer desta pesquisa.

Todos os elementos que envolvem os sentidos do sujeito que evoca suas lembranças do passado constituem apoio à memória. Ao tratar desta questão, não podemos deixar à margem um dos temas básicos da obra de Proust, a memória involuntária, interessante para o desenvolvimento deste trabalho. Para Proust existe a memória que depende da nossa intenção, isto é, da nossa vontade e decisão de buscar, uma espécie de arquivo que pode ser consultado, caso o indivíduo tome a iniciativa de fazê-lo. Mas esse tipo de memória, ao qual se dá o nome de memória voluntária, não dá conta das sensações e emoções experimentadas por nós em tempos remotos que, muitas vezes, estão fora de nossa consciência. As sensações e sentimentos referentes às experiências adormecidas no inconsciente só podem vir à tona graças a memória involuntária. Nesse sentido, o narrador adulto de Proust, ao degustar uma "madeleine", molhada no chá, saboreada por ele, em tempos de outrora, recorda momentos de sua infância, vividos em períodos de férias na pequena cidade de Cambray. As sensações experimentadas em decorrência do conjunto de elementos que compõem a situação em que o referido alimento é saboreado e o faz sentir uma grande emoção, repentinamente começa a lembrar não só dos acontecimentos similares da infância, vivida no passado, como, também, de toda a Cambray e de todas as experiências realizadas naquele tempo que o gosto, o cheiro e a textura do bolo fizeram aflorar em sua consciência (PY, 2004, p. 8.):

E de súbito a lembrança me apareceu. Aquele gosto era o do pedacinho de madeleine que minha tia Léonie me dava aos domingos pela manhã em Cambray (...) E logo reconheci o gosto do pedaço da madeleine mergulhado no chá que me dava minha tia (embora não soubesse ainda e devesse deixar para bem mais tarde a descoberta de por que essa lembrança me fazia tão feliz), logo a velha casa cinzenta que dava para a rua, onde estava o quarto dela, veio como um cenário de teatro... (PROUST, 2004, p. 53).

A passagem descrita revela o valor da memória involuntária no processo de "recuperação do tempo perdido". Apesar da degustação do bolo proporcionar felicidade ao narrador, trazendo-Ihe seu passado à tona, ela não lhe desperta, de imediato, a consciência para a causa da agradável sensação. Só mais tarde, por meio de outras experiências semelhantes, consegue refletir sobre o que lhe 
acontecera. Para Maria do Carmo Savietto, essa experiência vivenciada pelo narrador, proporcionada pelo encantamento da memória involuntária, representa uma espécie de libertação do sujeito, que o leva a uma introspecção, em que se dá o conhecimento do "Eu maior" e o "reencontro do ser consigo mesmo" (2002, p. 150). A memória involuntária quebra a ordem cronológica do tempo, para estabelecer a ordem "intemporal", na qual se apóia o ser redescoberto. Os momentos do passado são evocados, como afirma o narrador de Proust, através do sabor de um alimento, do perfume de uma flor, da visão duma paisagem, da calçada irregular de uma cidade e de tudo aquilo que percebemos no dia-a-dia e que, de uma forma ou de outra, tem semelhança com aquilo que sentimos no passado.

Na perspectiva de Gagnebin, esse episódio referente ao bolo "madeleine", encharcado no chá, saboreado - mnemonicamente - pelo narrador-protagonista, constitui no entanto "uma das chaves da estética proustiana" (2006, p. 145). Não se trata apenas de uma descrição do reencontro bem sucedido entre as sensações do passado e as sensações do presente, mas de uma busca incansável do sujeito, através da lembrança e da habilidade da escrita, de superar a passagem do tempo e a morte representadas na força do esquecimento, cujo poder pode aniquilar os empreendimentos da própria memória e da escrita. O trabalho da memória involuntária é, então, de libertar o que se encontra aprisionado no mundo do esquecimento. Na acepção de Proust, é inútil a tentativa de evocar o passado através da inteligência, pois ele está situado fora do alcance do sujeito, está alojado ocultamente em algum objeto material e só pode ser "resgatado", casualmente, através das relações sensitivas estabelecidas pelo sujeito com objetos que, por ventura, estejam ligados, pelas sensações que lhes proporcionam, aos eventos do passado. Ao serem lembrados esses acontecimentos são libertos da morte para a vida e passam a fazer parte novamente da existência do sujeito.

Para dar prosseguimento a essa abordagem, é imprescindível trazer aqui algumas ponderações de Ecléa Bosi, para quem "as pedras da cidade, enquanto permanecem, sustentam a memória” (BOSI, 1994, p. 444). Para a referida pesquisadora, a paisagem sonora, característica de um espaço e um tempo, também constitui apoio relevante à memória. Ao perder as paisagens visuais e sonoras, determinadas lembranças podem ser evocadas por meio de outros sons que perdurarem, com o passar do tempo, ou mesmo através de narrativas e diálogos com outras pessoas. Desse modo, o equilíbrio e a estabilidade do homem só podem 
ser atingidos mediante a presença de elementos causadores de sensações vividas, que se constituíram como um banco de sustentação e evocação das lembranças dos fatos ocorridos. No mundo moderno, se considerarmos a perspectiva de Ecléa Bosi, a existência dos grupos está estreitamente relacionada à "morfologia da cidade: esta ligação se desarticula quando a expansão industrial causa um grau intolerável de desenraizamento" (BOSI, 1994, P. 447). Assim, pode-se entender que os apoios da memória permitem ao indivíduo colocar-se como parte de um todo, tanto no que se refere ao mundo do presente quanto no que condiz com os contextos das gerações passadas. Mas na visão de Bosi, esta plenitude - alcançada pelo homem em tempos remotos, através da sua confiança, no convívio duradouro com seus iguais e na estabilidade dos espaços - se esvai diante da mobilidade constante, do isolamento do indivíduo, dos objetos e das relações humanas descartáveis, peculiares à sociedade industrial. Já para Py e Savietto o tema central de Em Busca do Tempo Perdido é a luta da atividade criadora contra o tempo, diante da impossibilidade de se encontrar na vida real um ponto fixo de referência ao qual o "eu" possa se ater.

O tema essencial de Proust "é o encontro desse ponto de referência na obra de arte" (2002, p. 8), evidenciando que a arte é uma maneira de se livrar do medo do fim que aniquila o sujeito. Somente a arte pode livrar a existência da ação devastadora do Tempo (representado na mitologia pelo deus Cronos), aquele que devora os próprios filhos.

É por meio da arte que o transitório e o efêmero tornam-se eternos. Em suma, a arte é a única saída pela qual o homem pode transcender a sua condição de mortal, ao permitir ao sujeito o acesso ao "conhecimento de um mundo restituído pelas reminiscências, incapaz de ser desvendado apenas pela inteligência" (SAVIETTO, 2002, p. 192). Nessa perspectiva, o próprio narrador de Proust destaca ainda a arte como o único meio que permite ao eu atingir o que há de mais complexo e sublime na inteligência humana. As revelações mais importantes realizadas pela memória a respeito da identidade do sujeito estão imersas no esquecimento, isto é guardadas no inconsciente, basta um estímulo exterior relacionado a algum dispositivo interior para trazê-las à luz do consciente, despertando-as do esquecimento (SAVIETTO, 2002, p. 152). Desse modo, ao especular sobre o passado e explorá-lo, através da memória involuntária, aquele que recorda acaba por desvendar traços mais complexos e profundos de sua identidade. Além do mais, ao abordar suas próprias experiências, o narrador acaba 
por tratar também do universo político, social e cultural no qual está inserido e muitas vezes das gerações que o antecedem. Nesse sentido, para Antonio Candido, a experiência pessoal "se confunde com a observação do mundo e a autobiografia se torna heterobiografia, história simultânea dos outros e da sociedade; sem sacrificar o cunho individual, filtro de tudo, o Narrador poético dá existência ao mundo..." (CANDIDO, 1987, p. 56).

De acordo com as observações de Saviaetto sobre as memórias de Pedro Nava, a escrita permite ao memorialista juntar e reorganizar as imagens fragmentadas de sua história de vida. O processo de narrar e construir as lembranças implica numa espécie de aglutinar "pedaços de si mesmo espalhados ao longo de diferentes épocas e lugares" por onde tenha passado, "almejando com isso reconstituir-se, rever-se e firmar sua identidade e sua presença no mundo" (SAVIETTO, 2002, p. 197). Neste sentido, o ato de escrever as memórias constitui uma forma de salvar o que poderia continuar disperso ou mesmo dissipar-se por completo.

Ao refletir sobre processo da tessitura de um texto, a partir do processo mnemônico, Pedro Brum Santos compara a habilidade exigida do narrador para tal com o "domínio da técnica de conjugar filigranas, com a perseverança e a prontidão que lembram o jogador, o arqueólogo, o paleontólogo e o protético" (SANTOS, 2002, p. 25). Para que os fragmentos de lembranças sejam encorpados numa unidade e adquiram sentido, faz-se necessário que se preencham os "vácuos" e os "rombos".

É preciso acrescentar, ainda, que a peculiaridade do ser constituído pelo narrador de memórias é resultado da fusão de inúmeras vozes, as quais ele busca identificar, trazendo à tona as lembranças de seu passado para, em seguida, decifrar e entender os inúmeros fios de memória que constituem a unidade do seu ser. Ao narrar sua história, o sujeito busca também desvendar figuras de seus antepassados, cujas vozes pulsam dentro de si, como fez, por exemplo, a narradora de Tereza Albues, ao apresentar acontecimentos com seus familiares que antecederam ao seu nascimento, conhecidos por ela através das narrativas de pessoas pertencentes às gerações anteriores à sua.

O narrador de memórias ao explorar suas origens não se restringe apenas ao universo familiar, envolve toda a sociedade e toda a realidade nacional de que faz parte. Assim a constituição do indivíduo se dá também a partir dos valores característicos da sociedade em que vive. Desse modo, a leitura de um texto 
de memória nos permite perceber quais são e de onde se originaram os elementos responsáveis pela constituição do "eu”. Em síntese, as narrativas de memória podem permitir tanto a "autorepresentação" quanto a "cosmorepresentação", pois "impossível seria captar a si mesmo sem entender-se ao âmbito do outro" (SAVIETTO, 2002, p. 198).

\subsection{Memória e Sociedade: Halbwachs}

O sociólogo francês Maurice Halbwachs (1877-1945) foi o principal responsável pelas bases teóricas que fundamentam a memória como uma constituição social. Essa concepção da memória como parte de um processo social teve por base a idéia de que os indivíduos não são seres isolados, mas seres humanos que interagem entre si, a partir de estruturas sociais delineadas.

Halbwachs estudou por muitos anos com o francês Henri Bérgson (18591861) que, provavelmente, tenha sido o primeiro filósofo a conceber a memória como atributo exclusivo da consciência humana (SANTOS, 2003). Bérgson, cuja filosofia foi de grande importância na primeira metade do século $X X$, se opôs tanto às concepções de memória que tivessem como base apenas a consciência, quanto às teses do campo da psicologia que abordavam a memória apenas como reações mecânicas do sistema nervoso.

Em Matéria e Memória, escrita em 1912, Bergson associa à subjetividade elementos próprios da matéria, possibilita assim focalizar a relação do corpo presente com o passado e, concomitantemente, intervém no processo das representações atuais. Sua maior preocupação é compreender como se estabelece a relação entre a conservação do passado e o presente, como se articula memória e percepção. As recordações do passado misturam-se às percepções atuais, ou as sobrepõem, ocupando todo o espaço da consciência do indivíduo. "A memória aparece como força subjetiva ao mesmo tempo profunda e ativa, latente e penetrante, oculta e invasora" (BOSI, 1994, p. 47). Bergson quer mostrar que o passado se conserva puro e independente em nosso espírito. Neste sentido, toda lembrança permanece como um potencial, permanece em estado latente no 
inconsciente. Bergson buscou dar à memória um estatuto espiritual distinto da percepção (BOSI, 1994, P. 53).

Quando se transita por um espaço, já visitado e conhecido, tem-se a sensação singular de um reencontro com as experiências já ali vivenciadas pelo sujeito em tempos de outrora. Por isso, em muitos casos, há a idéia de que o cenário revisitado por si só teria o poder de evocar os eventos a ele relacionados.

Halbwachs, ao desenvolver seus longos estudos sobre memória coletiva, pode ter radicalizado "uma das primeiras tentativas de Bergson de 'des-subjetivar' a noção de memória" (SANTOS, 2003, p. 21). Foi a questão da pureza da memória, defendida por Bergson, que Halbwachs se opôs, pois para ele lembrar não é trazer o passado à tona, reviver, mas refazer, repensar e reconstruir as lembranças das experiências vividas remotamente, a partir das idéias e imagens do momento presente. O referido sociólogo afirma que, de acordo com Bergson o passado permanece ileso dentro de nossa memória da mesma forma como foi para nós no momento dos acontecimentos. Em contrapartida, Halbwachs aponta a existência de determinados empecilhos ligados ao funcionamento do cérebro que impedem a evocação completa de todos os detalhes do evento lembrado. Assim, para este estudioso da memória enquanto um processo social, "não subsistem, em alguma galeria subterrânea de nosso pensamento, imagens completamente prontas, mas na sociedade, onde estão todas as indicações necessárias para reconstruir tais partes de nosso passado, as quais nós representamos de modo incompleto ou indistinto, ou que, até mesmo, cremos que provêm completamente de nossa memória" (2004, p. 81).

Em Os quadros sociais da memória (1925), Halbwachs argumenta que a recordação deve ser reconstruída. Não é possível reviver um acontecimento ao recordá-lo, pois imagens vistas e tudo que se tenha feito no passado não subsistem intactos na memória. Nesse sentido, a lembrança de um fato, por mais nítido que pareça ser, não coincide com a mesma imagem experimentada em tempos remotos. A percepção do sujeito, com o transcorrer dos anos, é modificada, suas idéias são alteradas, seus juízos de valores sobre a realidade são transformados e, assim, tudo aquilo de que se lembra também, com o tempo, vão ganhando novos contornos. E é nesse processo de mutação pelo qual passa a memória que a identidade do sujeito vai sendo construída continuamente. O passado se revela ao "eu" de forma imperfeita e inacabada, contrariando, assim, a ilusão de que o mesmo provém 
inteiro e completo da memória. Cada componente da sociedade é portador de um ponto de vista sobre uma determinada realidade do passado, ponto de vista este que também se modifica com o transcorrer das experiências. Assim, a visão bergsoniana da conservação total do passado só seria possível se o adulto conseguisse manter intacto o seu sistema de representações, costumes, hábitos e estabelecesse as mesmas relações sociais, o que é impossível na visão de Halbwachs.

Ao recordar, o sujeito traz à tona memórias que foram construídas coletivamente. As impressões do "eu" têm por base não só suas lembranças, mas também as lembranças das outras pessoas. Mesmo que se trate de acontecimentos presenciados apenas pelo sujeito, cujos objetivos só lhe dizem respeito, jamais estará sozinho. As inúmeras memórias auxiliam-se e apóiam-se umas nas outras.

O que Halbwachs denomina de "quadros sociais da memória" é a síntese, a combinação de todas as lembranças dos membros de uma mesma sociedade. Os quadros sociais da memória constituem "os instrumentos que a memória coletiva utiliza para reconstruir uma imagem do passado de acordo com cada época e em sintonia com as idéias dominantes da sociedade" (HALBWACHS, 2004a, p. 10). Tudo o que é desvendado pelo sujeito vem carregado de significação, até então, obscura à sua percepção, da qual apenas se pressente alguns traços. Ao voltar-se para o passado, as imagens e os aspectos dos elementos e seres vivenciados são revelados ao sujeito à luz das suas experiências acontecidas em momentos posteriores aos fatos recordados, especialmente conforme a situação do presente:

o novo quadro, projetado sobre os fatos que já conhecíamos, ali nos revela mais de um traço que nele se posiciona, e que dele recebe um significado mais claro. É assim que a memória se enriquece de bens alheios que, desde que se tenham enraizado e encontrado seu lugar, não se distinguem mais das outras lembranças (HALBWACHS, 2003a, p. 82).

Para Myrian dos Santos, o enfoque na memória coletiva dado por Halbwachs é tão intenso que torna complexa a constituição do indivíduo enquanto um ser uno. Desse modo fica difícil entender "individualidade e diferença, se acreditamos que há um campo básico de significações que antecede os indivíduos e que se impõe a eles". Se "as lembranças são distintas entre os indivíduos, é porque cada um deles tem um trajeto de vida único e, ao longo desta, adquire diferentes combinações das construções de sua trajetória de vida” (2003, p. 70-1). 
As narrativas, objeto de estudo desta pesquisa (Percursos e $O$ berro), estão voltadas para as experiências da infância das protagonistas, mas tecidas sob a perspectiva das mesmas depois de adultas e experientes. Assim, é relevante atentar, nesta perspectiva social de conceber a memória, sobre como se processa a memória dos adultos a respeito da própria infância. São olhares distintos de uma só personagem concebe o vivido: a perspectiva do "eu" do presente da narração é constituída pelas inúmeras experiências desenvolvidas pelos sujeitos, tendo como base essencial relações interpessoais estabelecidas por ele ao longo das várias fases de sua existência. Tanto em um texto quanto no outro, é preciso que se atente para a visão da menina que viveu os acontecimentos e se deixa envolver emocionalmente com os mesmos e o olhar da adulta definido pela maturidade e pelo distanciamento em relação às experiências relatadas. Nas duas obras, a maturidade e o conhecimento adquirido no longo intervalo de tempo que separa a infância (tempo da narrativa) da adulta (do tempo da narração) permite tanto a personagem principal de Tereza Albues quanto a de Wanda Ramos ponderar sobre os fatos narrados.

Analisando o processo de rememoração, observa-se que o adulto ao se recordar de um fato ocorrido na infância, ainda que sem a presença de qualquer testemunha, ele o reconstrói a partir das lembranças do lugar, das pessoas que o cercavam, e do contexto das diferentes épocas vivenciadas. É notável, neste caso, que as lembranças familiares consolidam e registram os eventos ocorridos na infância. A concepção de mundo do menino e a do adulto escritor se orientam de forma bastante oposta, tendo em vista que a natureza física, psíquica e social do sujeito varia a cada fase de sua existência. E essa diferenciação tem como motivo principal as inúmeras condições sociais vivenciadas pelo mesmo sujeito no decorrer de sua vida. Na perspectiva de Halbwachs é difícil para o adulto, devido à distância que o separa da infância, recuperar sua alma e seu sentimento de menino. Ao analisar este aspecto nas obras estudadas, observa-se que o distanciamento, estabelecido entre a mulher adulta do momento da narração e a menina, em torno da qual a maior parte do enredo se concentra, não é só em decorrência da passagem do tempo, mas também pela transformação pela qual passa a personagem principal durante o período de sua formação em Percursos e principalmente em $O$ berro, pois esta última enfatiza a "metamorfose" vivenciada pela personagem-narradora. 
O mundo da criança é muito mais restrito que o mundo do adulto. Uma criança com seus dez ou doze anos tem apenas uma idéia vaga e superficial da sociedade em sentido amplo, pois ela, além de freqüentar um espaço limitado em relação ao mundo do adulto, faz parte de apenas alguns pequenos grupos como a família, os ciclos de amigos da escola e das brincadeiras. A criança não sente necessidade de inserir seu pequeno mundo em um universo maior. Já o adulto o faz constantemente, tendo plena consciência de que a casa, a rua, o bairro e a cidade onde mora são parte integrante de um espaço bem mais amplo e complexo. A noção de espaço do adulto é muito mais ampla e complexa que a da criança. Muitas vezes os componentes do espaço doméstico são associadas pela criança às pessoas de sua família. O espírito criativo infantil, cheio de imaginação, transfigura o espaço, dando a este vida e estabelecendo uma relação afetiva com ele. Aos olhos da criança nenhuma parte do mundo é desprovida de elementos da natureza humana, de seres benfazejos ou malignos (HALBWACHS, 2004a).

A residência da primeira infância apresenta-se ao indivíduo como um espaço cheio de possíveis aventuras. De certa maneira, a criança tem um olhar muito próximo do que seria o olhar homem no momento inicial de seu processo de desenvolvimento cultural-humano correspondente ao período das sociedades primitivas, em que ele tinha uma relação mítica com o lugar onde habitava, ao atribuir a cada subdivisão espacial um domínio ou um império de um espírito, enfim de uma entidade A visão encantada da criança em relação aos espaços e ambientes em que vive, dá vitalidade, fascínio a sua existência. Por ser capaz de dialogar, através do seu imaginário fértil, com todos os seres a sua volta, tanto com os animados quanto com os inanimados, sua relação com o mundo se torna mais emotiva e afetiva, o que a leva, depois de adulta, a retomar o passado através da construção de uma narrativa envolvente e arrebatadora.

Para Bosi, a casa materna é o "centro geométrico do mundo" (1994, p. 435), aos olhos do menino; é a partir dela que a visão do pequeno vai expandindo rumo à cidade, às proximidades na região e ao mundo que, a cada ano transcorrido, vai sendo dominado pelas experiências e percepções do sujeito em crescimento. Nesse sentido, a primeira morada vai ganhando, no decorrer do tempo, na visão do menino em fase de crescimento, uma nova dimensão, isto é, a enorme casa, preenchida por móveis também grandes, vai sendo reduzida a nova dimensão, à medida que o sujeito torna-se adulto. 
Ao tratar do espaço na perspectiva do sujeito em formação, faz-se necessário atentar de imediato, nas narrativas em estudo, para a questão do espaço intimamente ligada à questão temporal onde se desenvolvem as ações relevantes das personagens principais por elas rememoradas. Em $O$ berro, 0 espaço do rancho do Cordeiro, em Mato Grosso, onde estão situadas as experiências mais remotas da protagonista no princípio de sua vida forma um par de opostos com a cidade de Nova York, onde estão localizadas suas experiências proeminentes da fase adulta, sendo que este espaço último demarca o ponto máximo de expansão dos horizontes da personagem-narradora. Analisando o percurso de vida da personagem ligado ao trajeto de sua formação pessoal, nota-se que o sítio do Cordeiro representa o seu ponto de partida e Nova York é o ponto de chegada almejado e atingido pela protagonista. Nesta abordagem da questão do espaço da narrativa, Percursos apresenta fortes pontos em comum com o texto da autora mato-grossense. Desde o título da obra - Percursos (De Luachimo ao Luena) - a seu enredo, a tessitura da narrativa sugere a idéia do lançar-se da heroína no trânsito de um espaço a outro, de um tempo a outro, pois o rio "Luachimo" representa o espaço e o mundo restrito de sua infância e o rio "Luena" o espaço e tempo principal de sua vida como adulta, ambos tratados com destaque no texto. $O$ rio Luachimo constitui ponto de partida do trajeto de vida e formação da heroína e o Luena o seu ponto de chegada por tratar das suas experiências contextualizadas no período Guerra Colonial como esposa de militar a trabalhar pelo Império Português, considerando que a Guerra foi um evento de grande relevância na formação pessoal, ideológica e política da personagem.

Não é necessário, de acordo com a abordagem de Halbwachs, que os "outros" estejam fisicamente presentes para que tomem parte da percepção do "eu" que, para melhor recordar, muitas vezes busca auxílio nas perspectivas daqueles que compartilham consigo as mesmas lembranças. $O$ escritor consegue criar no leitor a ilusão de estar diante das situações relembradas por ele a ponto de ter a sensação de reviver a infância ou qualquer outro período de sua existência. Sendo assim, não é o menino que sobrevive enquanto perspectiva, mas o adulto. Este recria o mundo do passado e o transforma muito mais em ficção que em representação de uma realidade (HALBWACHS, 2004b, p. 118). Pode-se dizer, então, que se o texto é capaz de emocionar o leitor - fazendo-o sentir-se como se estivesse diante de um fato real -, ele revela-se como verossímil, a ponto de simular 
uma realidade(ARISTÓTELES, 2000, 1447a - 1462b). É o imaginário, provocado geralmente pelo olhar da criança que viveu a experiência de seu lugar e tempo de menino, que contamina a visão do adulto-narrador para melhor lidar com o ficcional na recriação dos fatos narrados, colocando-os cada vez mais na esfera do provável.

Nesta questão da perspectiva do personagem-narrador, observa-se que 0 adulto mantém uma relação mais racional que a criança com o espaço onde habita. Mesmo o adulto que migrar para outro lugar, deixando para trás uma morada de muitos anos, terá a sensação de que perdeu parte de si mesmo, é como se perdesse parte de sua identidade. Halbwachs parte do pressuposto de que, uma vez perdido este espaço, determinadas lembranças vinculadas a ele podem se esvair. Mas como o adulto, distintamente da criança, não restringe seus pensamentos apenas ao recinto e arredores de sua morada, muitas das recordações poderão sobreviver, pois estas poderão estar vinculadas a outros objetos, a outros lugares e as percepções que vão além do espaço doméstico. $O$ adulto traz em si a possibilidade de guardar, de uma antiga morada, recordações mais ou menos complexas, considerando que ele poderá encontrar, em outras partes do mundo, elementos que o remetam ao já experimentado. A casa e seus arredores constituem, em sua mente, apenas um pequeno quadro contido em um quadro maior, que geralmente subsiste e vai permitir ao adulto evocar o pequeno espaço desaparecido de suas percepções. Nesse sentido, ao abandonar uma morada onde passara longa parte de sua vida, a criança teria muito mais razão de sentir-se em prejuízo que o adulto. A criança ou o jovem, como têm pouco tempo de existência, teriam toda uma vida de experiências contida ali naquele espaço, no qual estariam assentadas todas as suas lembranças. Ao perder uma antiga morada, o menino perde também o convivo com diversas pessoas significativas do seu ciclo de convivência. A mudança de casa, a dispersão dos membros da família retiram do menino todos os elementos de apoio a sua memória. Assim, as imagens do antigo lar pode se esvair juntamente com tudo aquilo que estiver a ele vinculado, de modo que a criança passa a não ter mais em que e em quem se apoiar para buscar suas lembranças a não ser em si próprio (HALBWACHS, 2004, p. 121).

Como o contexto, no qual estão inseridas as tramas dos textos analisados, trata do mundo moderno em que tudo é descartável e a tradição deu lugar ao progresso, ao desprezo a tudo que motiva o sujeito voltar-se para os acontecimentos vivenciados no passado, é bastante relevante que se busque, em 
Halbwachs, argumentos sobre o que significa para o ser humano o desaparecimento e a transformação dos quadros sociais da memória de um indivíduo.

O homem ocidental tem uma forma saudosista de se relacionar com o passado. Não são somente os anciãos, mas o homem de modo geral que "adota instintivamente, em relação ao tempo passado, a mesma atitude dos filósofos gregos que colocavam a idade de ouro, não no fim do mundo, mas no começo deste" (HALBWACHS, 2004b p. 130). Nesta perspectiva, mesmo que tenhamos consciência das dificuldades do passado, das experiências dolorosas, sempre nos convencemos de que o mundo que nos rodeia, no presente, é muito mais sem brilho e sem cor que o de nosso passado, especialmente em relação a nossa infância e nossa juventude.

Para o sociólogo, essa visão ilusória do passado, apresentada pelo memorialista, é decorrente da sensação de plenitude experimentada pela criança e pelo jovem, a qual é sempre superior à do adulto. A forma leve e desprendida com que a criança encara a própria vida lhe permite construir uma imagem do mundo bastante positiva, isto é, uma visão "colorida" da realidade. Quando adulto, para atender às exigências da sociedade de que faz parte, o ser humano, impõe a si determinados comportamentos e atividades, que acabam por tolher muito de sua liberdade e anseios, conseqüentemente, faz com que o mundo a sua volta perca o "colorido" e a graça, captados pela criança e pelo jovem.

Desse modo, exaltar o passado tem por base uma ilusão, fruto dos procedimentos da memória e, mais precisamente, da imaginação. Em se tratando de memória, não é a ação, mas os sentimentos que conduzem o sujeito a evocar suas lembranças. Conforme a perspectiva de Halbwachs, não é desejo de o indivíduo nutrir os sentimentos tristes, mas reforçar os bons e alegres. Por isto, o ser humano, na maioria das vezes, adquire o hábito de selecionar, em sua memória, as recordações felizes, considerando que a imaginação prima pela concatenação de pensamentos e de imagens agradáveis. Existem sim imaginações tristes, desconfortáveis provocadas por sentimentos dolorosos, oriundos dos acontecimentos indesejáveis, mas o normal é o indivíduo se ater muito pouco tempo a este tipo de lembrança. Trata-se, então na visão do sociólogo, de uma atitude de caráter vital, considerando que o ser humano tem a tendência de não desperdiçar suas energias com aquilo que o prejudica, exceto em casos de natureza patológica. Assim, é natural que esqueça os acontecimentos penosos do passado 
(CHALBWACHS, 2004b, p. 132). Se por um lado a sociedade, na qual está inserto, determina com precisão as ações e o lugar do sujeito, de outro, a memória lhe permite ter a ilusão de ter vivido no interior de grupos que não o aprisionaram e nada Ihe impuseram.

O meio social do presente motiva o indivíduo a recordar ou esquecer determinados acontecimentos de outrora; em compensação, a memória contemplativa ou a "memória-imaginação", pode levá-lo a isolar-se das demais pessoas de seu convívio atual. Quando se está a relembrar e a imaginar acontecimentos do passado, especialmente os mais antigos, o homem se distancia do meio social em que vive no presente; mas aquele que se abstrai do meio social presente se deixa absorver pelo meio social do passado, isto é, para próximo das pessoas que fizeram parte de seu mundo no passado (Idem, 133-4). Mesmo que o homem se distancie do convívio com as pessoas reais do seu dia-a-dia, quando seqüestrado do presente pelas recordações do passado e pelo imaginário retoma, através seus pensamentos, as relações sociais do passado. Até no momento em que o homem acredita estar só consigo mesmo, sua imaginação e sua memória nunca estão desconectadas do "outro", ou seja, do social. Sua percepção de mundo, seus pensamentos e todo seu conhecimento fazem presentes, no intelecto do indivíduo, os grupos dos quais fizera parte durante sua existência. Dialeticamente, entretanto, a evocação do passado pelo ser humano tem como norteio a subjetividade, à medida, em que ele é livre para evocá-lo quando quiser, no momento que lhe for oportuno.

Para Myrian Sepúveda dos Santos, que acredita na memória enquanto sujeito e objeto do conhecimento ao mesmo tempo, a identidade do sujeito é construída a partir daquilo que ele se lembra e portanto identidade e memória, tanto individual quanto coletiva, estão intimamente ligadas. A constituição do ser se dá a partir da memória. Memória não é, então, apenas pensamento, imaginário e construção social, mas também experiência de vida com o potencial primordial de modificar outras experiências futuras: "A memória, portanto, excede o escopo da mente humana, do corpo, do aparelho sensitivo e motor e do tempo físico, pois ela também é resultado de si mesma, ela é subjetivada em representações, rituais, textos e comemorações" (SANTOS, 2003, p. 26).

As recordações se dão conforme os interesses dos sujeitos, guiados por suas concepções de mundo, que variam conforme as relações estabelecidas nos 
grupos, a história de vida e a faixa etária de cada um (HALBWACHS, 1004b, p.115). Em suma, relembrar não seria reencontrar, mas sim reconstruir a partir de signos constituídos socialmente. O convívio entre as pessoas se dá essencialmente por meio da linguagem, o elemento fundamental para que memória exerça seus papel. A linguagem traz em si uma ampla e profunda significação, desenvolvida ao longo da existência da sociedade e cultura a que pertence. A linguagem é, para o ser humano, o instrumento imprescindível no que se refere à socialização da memória. Segundo Ecléa Bosi, as convenções verbais produzidas coletivamente constituem o quadro ao mesmo tempo mais elementar e mais estável da memória coletiva (BOSI, 1994, p. 56).

\subsection{Do narrador experiente ao narrador ouvinte}

Narrar é uma atividade milenar e está ligada, em sentido imediato, à oralidade. Na história de nossos antepassados, sempre que se reuniram duas ou mais pessoas, se fizeram presentes 0 ato de ouvir e de contar histórias. Narrar constituiu-se tradicionalmente como uma ação coletiva e afetiva entre os homens que, muitas vezes, ocorria embalada pelo conforto do calor e pelo lusco-fusco da luz de uma fogueira, de uma lareira ou mesmo de um aconchegante fogão a lenha.

A habilidade de narrar tem permitido aos seres humanos a transmissão e a troca de experiências entre si, tanto no que diz respeito à extensão geográfica, através do trânsito de um lugar ao outro, isto é, da viagem, quanto na extensão do tempo, em que as experiências vão sendo enriquecidas ao longo dos séculos, constituindo assim a tradição cultural de cada povo. É graças à habilidade de contar, amparada pelas funções de natureza psicológica e social da memória, que nos constituímos como seres humanos capazes de nos transformar ao longo do tempo. São as experiências de nossos antepassados que nos permitiram reconstruir e constituir novos aprendizados. Observa-se que é o acúmulo de experiências vividas que se estabelecem como matéria-prima para o bom desempenho do narrador. Quanto mais velho, mais conteúdo e habilidade com a linguagem o homem dispõe para narrar. Esta abordagem pode ser ilustrada e melhor esclarecida a partir de uma reflexão que inicia o ensaio de Davi Arrigucci Júnior sobre as memórias de Pedro Nava: 
O homem que escreveu essas linhas levou anos envelhecendo na quietude escondida, como um vinho bom, uma substância viva e generosa que trazia em si, antes de se dar a conhecer por inteiro. Foi acumulando aos poucos uma ampla e profunda experiência, amadurecida depois sem pressa, pacientemente, puxando pela memória raízes distantes, da infância, de outrora para só então começar a narrar (ARRIGUCCI JÚNIOR, 1987, p. 67).

Ao introduzir seu texto, dessa forma, Arrigucci Júnior não só ressalta a riqueza da experiência apresentada pelo narrador, mas também, o trabalho ardiloso, algo que o aproxima das peculiaridades do poeta "artífice" de Aristóteles. Postura esta que se opõe aos atropelos da vida contemporânea, em que a elaboração estética se dá com base na rapidez das ações humanas, resultando em conclusões apressadas, sem consistência, próprias de um mundo centrado nas aparências, nas relações descartáveis dos homens com o meio de que faz parte juntamente com os seus utensílios. O caráter da narrativa de Nava, voltada para as raízes e para as tradições familiares, é assim delineada de modo a assinalar sua perenidade, cuja índole suplanta o caráter temporário da informação veiculado pelos meios de comunicação. Ao apostar na maturidade paciente da experiência de quem narra, Arrigucci o faz à luz das reflexões de Walter Benjamin, estudo imprescindível, neste trabalho, para a compreensão do processo de rememoração desempenhado pelo narrador.

Em 1936, em seu texto "O Narrador: considerações sobre a obra de Nicolai Lescov," o filósofo frankfurdiano já observava que "a arte de narrar" estava em "vias de extinção", pois eram "cada vez mais raras" as pessoas que sabiam "narrar devidamente" (1994, 197-8). Na primeira metade do século XX, ele já pondera que as pessoas não contavam com nenhum motivo para narrar. Constatase, então, o fim da narração tradicional. A guerra, motivo da origem de inúmeras narrativas ao longo das tradições literária, não inspira mais ninguém como, em tempos de outrora, inspirou os grandes narradores épicos e, de modo especial, Homero. Os ex-combatentes da Primeira Grande Guerra voltavam emudecidos, pois os campos de batalhas eram cada vez mais pobres em experiências comunicáveis. Os livros, que trouxeram como tema as atividades bélicas deste evento marcante da história da humanidade, "nada tinham em comum com uma experiência transmitida de boca em boca" (BENJAMIN, 1994, p.198). Os seres humanos passaram a ser 
privados da faculdade de intercambiar experiências, a qual sempre lhes pareceu tão segura e peculiar.

A forma como a memória é concebida ao longo da história do mundo ocidental sofreu uma alteração relevante no contexto do mundo moderno, tanto no campo da arte, da literatura, quanto no campo das ciências sociais. A memória enquanto tradição, enquanto aprendizado ficou à deriva no mundo do reinado da informação. A substituição do artesão pelo operário de fábrica e da indústria limitou as atividades, aniquilou o desenvolvimento humano. Os atos mecânicos e repetitivos não permitiram mais ao homem utilizar do aprendizado que acumulara durante toda sua existência. A experiência perdeu seu valor, não sendo mais transmitida de pessoa para pessoa ao longo dos séculos; o que resultou na ausência da transmissão do saber e dos valores entre as gerações. O tempo, desvinculado da experiência humana, tornou-se impessoal, regulado, e passou a exercer controle sobre as ações humanas. A Memória, antes transmitida pelos objetos passados de pai para filhos, de avós para netos e pelas marcas deixadas pelos homens nos espaços onde habitaram durante várias gerações, agora não encontra mais apoio no espaço do capital, caracterizado pelo transitório, pelo descartável, muitas vezes habitado pelo homem "desenraizado" e/ou em constante "desenraizamento"8 se sobrepõe aos valores humanos.

Conforme a acepção benjaminiana, as mais elevadas das narrativas escritas são aquelas que se nutrem das manifestações orais, fruto do imaginário e das lembranças de caráter coletivo. Ao observar as representações discursivas das experiências do "eu", percebe-se que as histórias contadas pelos familiares e amigos do narrador-personagem passam a compor grande parte das narrativas de memória.

$\mathrm{Na}$ perspectiva benjaminiana, a figura do narrador só é plenamente palpável se apresentar, imbricados em si, o narrador viajante que, por perambular por diferentes espaços, tem muito o que contar e o narrador sedentário que, por estar preso a suas raízes, passa toda uma existência sem sair de sua terra, conhece suas narrativas e tradições. Com base nesse pressuposto teórico é possível observar, que no texto de Tereza Albues, aparecem dois contadores de

\footnotetext{
${ }^{8}$ Os termos "desenraizado" e "desenraizamento" são utilizados a partir dos conceitos abordados por Simone Weil, no seu texto "O Desenraizamento", In: O Enraizamento, 2001, p. 43-272.
} 
história: o pai e o andarilho Benjamin Barbudo. O primeiro, cujo perfil (apesar do seu perambular pelo interior de Mato Grosso, residindo em diversos lugares) o aproxima das peculiaridades do narrador sedentário, passa horas a contar à filha os dramas de seu passado e do passado de sua família. O segundo é um tipo muito próximo do que seria o narrador viajante, definido pela narradora como um andarilho. Este coloca a protagonista em contato com saberes de índole sobrenatural, levando-a a compreender certas razões de sua própria existência. Em Wanda Ramos, o narrador sedentário está representado na figura do negro, criado (Frederico) da família, que entretém a heroína com as histórias e explicações sobre os eventos da cultura do colonizado. Já os traços distintivos do narrador viajante, em Percursos, se fazem presentes nos traços distintivos da protagonista, cuja vida e formação são abalizadas por diversas viagens a Portugal. A viagem é também um elemento bastante definidor da personagem-narradora de $O$ berro: além de morar numa megalópole, habitada, por pessoas oriundas de diversas nacionalidades, a personagem ainda passa pela experiência de conhecer diferentes lugares em todo o mundo.

O narrador, para Benjamin, sempre foi alguém que sabia "dar conselhos". O "conselho", "tecido na substância viva da existência" (1994, 200-1), a experiência, poderia ser reconhecida essencialmente por sabedoria, a qual era assimilada e apoderada pelas pessoas por meio da arte de contar e ouvir histórias. Como as experiências perderam o seu valor comunicável, a prática de ouvir ou dar conselhos caiu em desuso nas relações interpessoais.

Assim, a prática de narrar vai definhando a cada dia e a sabedoria - 0 lado épico da verdade - aos poucos vai se desvanecendo (BENJAMIN, 1994, p. 200). Trata-se, então, de uma transformação relevante no seio da humanidade, pois, segundo Benjamin, as experiências passadas de geração a geração e de pessoa a pessoa constituem a fonte a que recorrem todos os narradores. $E$, dentre as narrativas escritas, as melhores qualificadas quanto ao processo criativo são aquelas que mais se assemelham às histórias orais. Conforme afirma o filósofo em questão, no cotidiano da vida, quem se sobressai em aspectos de humanidade são as pessoas que têm o que contar, pois estas não se deixam contaminar pelas futilidades do consumismo e do mundo moderno, ou seja, pela "pobreza da experiência" do mundo atual. 
Em "Experiência e Pobreza", Benjamim declara que a perda da experiência, tem como conseqüência o desaparecimento da forma tradicional de narrar que é tema predominante em "O narrador". Essas duas perdas têm como razão o sistema de vida moderno e contemporâneo, que impõe ao indivíduo um ritmo que o silencia e torna suas experiências não mais comunicáveis. Enquanto para Benjamin o processo de queda da experiência (tema tratado no texto "Experiência e Pobreza") e, conseqüentemente, da narrativa (tema abordado no ensaio intitulado "O Narrador") culmina com o evento da Primeira Grande Guerra, para Jane Marie Gagnebin, pesquisadora do referido filósofo nos dias atuais, a crise vivenciada pela narrativa tradicional e pela experiência inicia-se com a Primeira Guerra, mas não culmina com esta. Nesse sentido, Benjamin aponta a dificuldade para a linguagem cotidiana e para narração tradicional de "assimilar o choque, o trauma, diz Freud, na mesma época, porque este, por definição, fere, separa, corta do sujeito o acesso ao simbólico, particularmente à linguagem” (GAGNEBIN, 2004, p. 87).

Com o gradativo fim das atividades ligadas às faculdades da memória, o homem contemporâneo perde o vínculo com as tradições culturais; o que é contraditório à existência humana, considerando que esta se constituiu a partir da memória e de todo o saber acumulado milenarmente pelos homens, desde as suas origens. Gagnebin observa que Benjamin, além de tratar do fim da narração tradicional no texto "O Narrador", esboça a idéia do surgimento de uma outra narração oriunda das ruínas da narrativa, "uma transmissão entre os cacos de uma tradição em migalhas" (Idem, p. 90). Com base no pensamento de Heródoto, seria o caso de não deixar os mortos e nem o passado cairem no esquecimento. E para isso seria necessário que a figura do narrador adquirisse um caráter mais humilde, menos triunfante; movido pela pobreza ele seria, para Benjamin, semelhante ao catador de sucata, de lixo, enfim, de cacos e detritos com a meta especialmente de não deixar que nada se esvaia no tempo. Esse "narrador sucateiro" não tem por objetivo tratar dos grandes feitos, mas recolher tudo "aquilo que é deixado de lado como algo que não tem significação, algo que parece não ter nem importância nem sentido, (...); o narrador e o historiador deveriam transmitir o que a tradição, oficial ou dominante, justamente não recorda". É, então, "a transmissão do inenarrável" (Idem, p. 90). 
Nesse sentido, ao discutirmos sobre essa nova forma de narrar e de trabalho com a memória, é imprescindível que levemos em consideração as dificuldades de narração das experiências comuns. De acordo com Gagnebin, ao lidar com o discurso de memórias, é necessário que tomemos os devidos cuidados para não cair na "celebração vazia", marcada pela "ineficácia dos bons sentimentos", da pieguice, rapidamente absorvida pela história oficial. Nesta nova proposta, a atividade de rememoração, ao invés de repetir apenas o que se recorda, busca também preencher as lacunas, os brancos, aquilo que ficou no esquecimento ou recalcado, para expressar-se muitas vezes com "hesitações, solavancos, incompletude, aquilo que ainda não teve direito nem à lembrança nem às palavras. A fidelidade ao passado, não sendo um fim em si, visa à transformação do presente" (Idem, p. 91).

Jane Marie Gagnebin lembra, em seu estudo, das referências textuais que Benjamin faz para explicar suas abordagens nessa relação do passado com o presente - à fábula do vinhateiro que, no leito de morte fala a seus filhos transmitindo-Ihes uma experiência, e ao poema "Apague os Rastros" de Brechet, cujo tema é a quebra da transmissão da tradição - e acrescenta uma outra figura de narração, que é o sonho do Primo Levi no campo de Auschwitz (LEVI, 1988). Primo Levi, como todos seus companheiros, sonha em voltar para a casa, com a alegria imensa de poder contar aos seus toda hostilidade experimentada naquele mundo de horror, mas é despertado repentinamente por um pesadelo, a possibilidade de não ser ouvido, pois no sonho seus ouvintes levantam um a um e vão embora, indiferentes às palavras do narrador. Neste caso, trata-se então da experiência inenarrável do horror, do indizível, não pela incapacidade de quem narra, questão já bastante tratada pelos estudiosos de Benjamin, mas pela indiferença do ouvinte inatingível, tema para o qual a pesquisadora nos chama a atenção. Desse modo, Gagnebin trata da memória no âmbito da literatura de testemunho e aponta para as causas da incomunicabilidade da experiência traumática: a fixação doentia do indivíduo sobre seu passado traumático, isto é, ele experimenta uma espécie de ressentimento em relação ao vivido, que o impede de viver bem o presente, e a identificação que, muitas vezes nem sendo o indivíduo herdeiro direto do evento traumático, ele se identifica, na narrativa, com uma das partes envolvidas, com a vítima ou com o algoz. 
Fora desse círculo de fixação e de identificação poderia acontecer, como propõe a pesquisadora de Benjamin, um outro lugar, ocupado por aquele que aponta para um mundo distinto, que não vai embora, que ouve a narração, por mais que esta lhe seja insuportável, e não deixa o narrador em desespero, como acontece no sonho do Primo Levi. É possível entender que, depois de ouvir a história neste contexto, alguém possa transmiti-la para outrem com palavras distintas, ampliando assim o conceito de testemunha: pois testemunha não seria apenas aquele que presenciou o acontecido, mas também aquele que ouviu a insuportável história do "outro" e a passa adiante, mesclando suas palavras com as desse "outro". O sofrimento indizível adquire expressividade na voz deste ouvinte, que também assume o papel de narrador, retomando o passado de maneira reflexiva, o que pode contribuir para a supressão da hostilidade do meio social descrito na narrativa, de modo que as formas de sofrimento, semelhantes àquela causada pelo holocausto, não voltem a se repetir.

\section{6. "As escrituras do eu" e os seus contornos 9}

Depois de tantas leituras, é bastante complexo definir e traçar as balizas das "escrituras do eu". O leitor enfrenta dificuldades em estabelecer as fronteiras entre os diversos gêneros constituídos por essa literatura de teor "intimista" como a autobiografia, o diário íntimo, as memórias, a literatura de testemunho. Ao refletir sobre a literatura de natureza confessional, a autobiografia é um dos primeiros conceitos a ser discernido, até porque é um termo utilizado por vários estudiosos dessa temática para designá-la no seu sentido geral, amplo.

A tendência à autobiografia acompanha 0 ser humano desde os primórdios de sua existência, especialmente a partir do aparecimento da escrita; mas o fortalecimento dos gêneros vinculados aos escritos do "eu" só acontece com o desenvolvimento do sistema capitalista e a ascensão e o estabelecimento da sociedade burguesa calcada na difusão do conceito de indivíduo: "quando, no Ocidente, o homem adquire a convicção histórica de sua existência” (MACIEL, p. 3). Se o uso freqüente do vocábulo "autobiografia" só ocorreu mesmo a partir do século

\footnotetext{
9 "Escrituras do eu" é uma expressão utilizada por Georges Gusdorf como título de um de seus livros (Les escritures du mol), o qual versa sobre autobiografia, diários e memórias.
} 
XIX, o auge da escrita confessional, cujo princípio se dá no século XVIII, se instaura no início do século XX. Quando se leva em conta a natureza da autobiografia enquanto uma necessidade do ser humano de falar sobre si, suas experiências, enfim, sobre sua vida, a origem dessa forma literária é concomitante ao aparecimento da linguagem oral. Autobiografia é uma palavra grega (autobiographia): autós significa próprio, bíos é o mesmo que vida e gráphein é escrever, isto é, autobiografia refere-se à atividade do sujeito de escrever sobre sua própria vida. Para Moisés, autobiografia é caracterizada pelo "relato objetivo e completo de uma existência" (1999, p. 50).

Um dos maiores estudiosos deste gênero, Philippe Lejeune, publica, em 1973, o texto O Pacto Autobiográfico e apresenta a seguinte definição para conceito de autobiografia: "narrativa retrospectiva em prosa que uma pessoa real faz de sua própria existência, quando focaliza sua história individual, em particular a história de sua personalidade" (2008, p. 14). Este conceito de autobiografia foi retomado por Lejeune em vários de seus textos, produzidos em momentos posteriores, não no sentido de reafirmá-lo, mais de ponderar sobre suas afirmações. O pesquisador alega que o que era para tornar-se apenas um ponto de partida tornou-se erroneamente, no entendimento dos outros teóricos e críticos do tema, um ponto de chegada.

$\mathrm{Na}$ abordagem primeira sobre a escrita de cunho pessoal, Lejeune tem por parâmetro o processo da narração da obra, em que o autor estabelece um pacto com o seu leitor, no sentido de deixar evidências de que o texto trata de sua própria existência. Para ele "um autobiógrafo não é alguém que diz a verdade sobre a vida, mas alguém que diz que a diz" (2003, P. 38). É importante que se analise com cuidado essa colocação de Lejeune tendo por fundamento o que observa Antonio Candido a respeito das declarações dos escritores ao tratar da criação de seus próprios personagens. Para o crítico, Mauriac (teórico e romancista) ao tratar de sua própria criação pode ter se enganado: "Ele pode pensar que copiou quando inventou; que exprimiu a si mesmo, quando se deformou; ou que se deformou, quando se confessou" (CANDIDO, 2007, p. 69).

Sinteticamente, Lejeune, com o passar do tempo, ganha maior maturidade em relação a seu tema de pesquisa e delineia outros contornos para a autobiografia. A narrativa autobiográfica em prosa nos seus escritos da década de oitenta e do início do novo milênio abre novos espaços para outras modalidades de 
auto-expressão, como a poesia, o auto-retrato e o cinema. O sujeito é o foco de abordagem, considerando que é de sua vida pessoal que provém a matéria-prima do gênero em questão. A narrativa dá conta da constituição do eu e de sua personalidade, numa visão particular e retrospectiva do autor em relação ao passado, e o sujeito tem sua identidade demarcada pela tríade "autor-narradorpersonagem", à qual Lejeune, em algum momento de suas novas abordagens, nomeia de "tríade do Espírito Santo".

Nessa perspectiva, o gênero autobiográfico estabelece com o seu leitor uma relação contratual, posta sobre três pilares definidores: o pacto autobiográfico, centrado na instância do autor; o pacto referencial constituído a partir da escritura do texto e, por fim, o pacto da leitura configurado na recepção do leitor. Observa-se, então, que a identidade "autor-narrador-personagem" é o elemento condutor do "pacto autobiográfico". Neste, Lejeune não se preocupa com a veracidade dos fatos, mas, sim, se o nome do escritor expresso na capa, dado extra-texto, coincide com o nome do narrador e do personagem dentro do texto. Não importa se o que o texto diz é verdadeiro ou não, mas sim se a "identidade é real". Em seguida, Lejeune trata da natureza "referencial" do texto autobiográfico (e biográfico também). "Seu objetivo não é a simples verossimilhança, mas a semelhança com o verdadeiro" (DAMIÃO, 2006, p. 36). Por último estabelece-se o "pacto da leitura", considerando que a definição do gênero está assentada na "problemática da recepção estética" (Idem). As condições históricas da recepção determinam em grande parte o "pacto de leitura"

Lejeune pondera sobre suas afirmações no passado:

quando volto a examinar minha definição de 1973, o que primeiro me chama atenção é ver que ela trata da enunciação, da narrativa, do tema, mas não das funções da autobiografia, nem do seu discurso argumentativo. (...) muito cordatamente não ponho nunca a questão de saber se a autobiografia é ou não literatura (os meus exemplos são tirados tanto de indivíduos obscuros como de grandes escritores), e que, quanto ao contrato de leitura, me concentro na oposição entre ficção e autobiografia. (2003, p. 47-8).

Possivelmente o que há de mais importante na abordagem de Lejeune para esta pesquisa é a sua preocupação em dar aberturas, deixar espaços para outras entradas, não dando uma definição rígida para o gênero em questão; de modo que o autobiográfico ocupa zonas fronteiriças existente entre o gênero 
ficcional e seu oposto. Os casos da autobiografia narrada em terceira pessoa, das "memórias imaginadas", das "autoficções" são exemplos expressivos dessa abertura estabelecida pelo teórico em relação ao conceito abordado que abrangeria certamente o romance autobiográfico. Considerando essa flexibilidade na definição do gênero autobiográfico, podemos inserir neste estudo a narrativa de Percursos, de Wanda Ramos - que, como já foi observado, apresenta um discurso em terceira pessoa mediando a fala da personagem, cujo perfil, coincide com o da autora - e a narrativa de $O$ berro, de Albues - em que o enredo é constituído pelos acontecimentos condizentes com as experiências da autora no passado, os quais são permeados por inúmeros elementos oriundos do imaginário. No caso da obra mato-grossense, junto do real rememorado, o imaginário, além de contribuir para unidade da narrativa, faz com que determinadas passagens se aproxime do fantástico ou do maravilhoso: de certa maneira, esses aspectos de natureza fantástica, em contraposição, coincide com a visão mística da autora.

A própria cena de abertura do livro nos transporta o leitor para o mundo de ficção: "Minha mãe me pariu de pé, tanta pressa tinha eu de vir ao mundo que lhe dei tempo de voltar à rede..." (BCN, p. 11). Há passagens do texto em que a narradora explicita o próprio ato da criação dos textos amparados na rememoração: "Solto do trampolim, apanho no ar rostos, pernas, braços, um olhar, um sorriso, corpo inteiro de pessoas que da minha vida partilharam, que elas venham comigo nesta saga que não sei onde começa, que diria do fim?" (BCN, p. 12). É notável que, tanto numa obra quanto na outra, as protagonistas narradoras, recriações de si mesmas elaboradas por suas próprias autoras, apresentam-se conscientes do processo de diluição de fronteiras dos gêneros literários: autobiografia, romance autobiográfico e memória; memória e ficção, em relação a seus semelhantes, como memórias e confissão, e entre a representação do real e do ficcional. Semelhante ao romance, autobiografia é, um conceito elástico, por adquirir com a mudança de contexto tanto no tempo quanto no espaço, outras formas de expressão.

A dissolução de fronteira também acontece na mistura estabelecida entre a literatura e as artes plástica. Tanto a narradora de Tereza Albues, quanto a protagonista de Wanda Ramos apontam uma proximidade significativa entre a forma como a paisagem se revela na escrita através da memória, na arte de pintar. Em $O$ berro, "Apanho o pincel, misturo as tintas, a paisagem nasce (...) Cadê as mãozinhas da menina? (...) Dedilha as cordas com leveza, é melodia que vem de longe..." ( $p$. 
228) e, em Percursos, “...o exercício continuado e pertinaz de contornos de corpos sobre o papel, pequenas orgias, dizia-se, corpos de homens e mulheres em requebros, dobrados sobre eles" (p. 20).

O diário íntimo é um outro gênero da literatura "intimista" que deve ser abordado nesta pesquisa no sentido de não confundi-lo com a autobiografia. A idéia do diário no sentido específico de datar e anotar os acontecimentos do dia-a-dia só vai surgir no fim da idade média, e adquire maior freqüência enquanto produção a partir do século XIX. Como a autobiografia, o diário é também uma narrativa voltada para "eu". Este se distingue daquela pelo fato de que no diário o tempo da narração é muito próximo do tempo dos acontecimentos abordados. É um retorno ao passado, mas a um passado recente. Pelo menos, essas peculiaridade do diário são emitidas ao leitor, em que tem-se a ilusão de que a constituição deste gênero acontece de forma espontânea e imediata.

A leitura dos textos entrecortados pelas datas e pelo registro diário dos fatos quotidianos nos passa a idéia de que o mesmo é sempre escrito na intimidade e não sofre nenhuma transformação ao passar, através da publicação, para a esfera pública. Um exemplo desta constatação está no livro de Helena Morley, Minha vida de menina, cuja leitura nos leva a crer piamente em seu estado de pureza, por ter sido escrito por uma adolescente do final do século XIX, sem passar por nenhum crivo ou mudança proveniente das mão e perspectiva de uma autora experiente. Em contrapartida, alguns críticos já apontam no texto elementos contidos em sua composição incoerente com o perfil e idade da menina que o escreveu. Pode ter sido escrito sim no final do século XIX, mas reformulado no momento de sua publicação, em 1942, levando em conta que sua autora já era dona de conhecimento e maturidade suficientes para reelaborá-lo, em conformidade com nível intelectual e de exigência seu e de sua época. Fato este que está relacionado com uma questão preponderante no âmbito do gênero do diário, que é a passagem do texto de teor íntimo, privado e secreto para a instância do domínio público. Segundo Sheila Maciel, "as confidências sobre si mesmo sofrem modificações e recortes que as transformam numa espécie de ficção em que o caráter de texto espontâneo é calculado" (MACIEL, P. 07). Em se tratando de diário, observa-se que muitos são escritos e poucos são lidos. Poucos são publicados e muitos são engavetados, destruídos ou terminam no lixo. 
Em entrevista a Jovita Maria Gerheim Noronha, Philippe Lejeune observa que a escrita do diário não intimida quem o faz: "Todos acham no direito de escrever um e se crêem capazes de fazê-lo. Mas é uma escrita invisível (...) quase nunca publicada"(2000, p.24) e por isso quase nunca lida. Esse é um dos fatores que distingue o diário das memórias e da autobiografia, em que poucas são escritas, mas muitas são lidas.

A autobiografia e as memórias são escritas para a apreciação de inúmeros leitores. Pressupõe-se então neste caso, no processo de sua criação, a existência do "outro" isto é, do público leitor, portanto há uma espécie de "autoconsciência do discurso". Nesse sentido, Fhilippe Lejeune em Le pacte autobiographique, afirma que o autobiógrafo, além de requerer do seu leitor "reconhecimento, aprovação, amor", propõe-lhe "reciprocidade", pois, aquele que lê uma autobiografia é, mesmo contra sua vontade, obrigado a refletir sobre sua própria existência (1975, p. 14-7). Para Lejeune, as autobiografias de escritores são, na verdade, uma produção de uma restrita parcela da sociedade. Em sua perspectiva, todo ser humano tem direito de escrever sua história pessoal, sem se preocupar em submeter seus relatos às leis específicas das produções literárias, pois o texto autobiográfico deve apresentar suas leis específicas. Ao não qualificar a autobiografia como um texto literário, Lejeune pretende, de certa forma, assegurar a todos os componentes da sociedade o direito à escrita das narrativas de cunho pessoal.

Ao analisar o texto de memória ou autobiografia, Larthomas observa que existe uma expressiva liberdade de uso dos tempos verbais (1998, p. 190-2). Ao analisar Mémoiries de Guerre, de autoria do general De Gaulle, ressalta que o uso do presente, referindo-se a fatos experimentados, indica que o passado está sendo revivido por aquele que rememora. Esta afirmação não procede de acordo com a visão de Halbwachs, melhor detalhada logo mais à frente neste capítulo, para quem não há possibilidade de se trazer o passado à tona tal e qual aconteceram os fatos. O que é possível, na realidade, é uma interpretação deste passado. A rememoração, nesse caso, é norteada pelo tipo de vivência social estabelecida no presente pelo sujeito, cuja história de vida, assinalada pelas diversas inserções em inúmeros grupos, vai contribuir para a realização da sua interpretação daquilo que recorda.

O uso do verbo no presente para tratar de eventos passados pode ser o resultado da engenhosidade do escritor, no sentido de seduzir o leitor, enredando-o. 
O envolvimento do leitor com o que lê, a ponto de se sentir transportado para o passado dos acontecimentos relatados, cresce ou diminui conforme o grau de verossimilhança presente na narrativa.

Em certos casos, o habitual uso do verbo no presente dá ao leitor pistas referentes ao funcionamento da memória, em que as lembranças, muitas vezes, não aparecem numa ordem cronológica, mas sim dispostas numa outra ordem que pode estar relacionada à seqüência de evocações, que acontecem conforme inúmeras situações como: "palavra puxa palavra"; uma imagem ou um pensamento lembra um acontecimento; uma música, um perfume, enfim, as diversas sensações vividas pelo sujeito podem lhe trazer à tona de seu inconsciente inúmeras recordações.

Nesse sentido, as experiências do passado podem afetar o olhar do narrador em relação ao presente da narração, como se observa nesta passagem de O berro:

Sou uma criança com dois anos, choro de dor de barriga, tenho um novelo de vermes nas tripas, visíveis pelo volume e movimento que fazem na pança inchada, sinto cólicas infernais, berro, tenho as faces arroxeadas, berro, ainda não sei falar, papai me carrega e anda comigo pelo quarto tentando me acalmar, continuo berrando. Tão alto que me ouvem nas ruas de Nova York, (...) os bichos resistem, não querem ser expulsos do ventre morno, reforçam ninhada, me torturam sem piedade, até quando? Eternamente, se ao escrever sinto as fisgadas e do alívio não me recordo ( $B C N$, p. 12).

Há também percepções de fatos de outrora que podem se confundir com as percepções de outros passados próximos e mesmo do presente. Na passagem da narrativa acima citada o vocábulo "ventre", símbolo do aconchego e da proteção, aparece infestado por "vermes" que o consomem de modo contínuo e lentamente, provocando, assim, uma dor visceral na protagonista. Tanto ventre quanto verme referem-se à idéia da transformação na conduta da personagem.

A abordagem do conceito de autobiografia de certa forma remete 0 pesquisador refletir sobre o conceito de memória. Conforme as palavras de Sheila Maciel, as Memórias são uma parcela da literatura autobiográfica mais reconhecida como puramente literária, muito provavelmente pela maior liberdade imaginativa que a elas está vinculada. Se a autobiografia é um gênero, já definido pela autora, como um gênero diferente que tem suas peculiaridades, não pode conter dentro de si o gênero memória que também apresenta características próprias, que o define como 
tal, lado a lado com a autobiografia. O que há entre os dois são pontos de coincidência como o próprio ato de rememorar, o uso do narrador-personagem, a recriação dos fatos verídicos, etc. Para Maciel as memórias "são uma busca de recordações por parte do eu-narrador com o intuito de evocar pessoas e acontecimentos que sejam representativos para um momento posterior, do qual este eu escreve" (p.08).

O interessante dessa definição é que o foco do gênero da memória não é tão só o indivíduo a narrar suas experiências pessoais, como acontece na autobiografia, mas também experiências de outras pessoas que, de algum modo, estão relacionadas ao percurso de vida do "eu-narrador". A abrangência da narrativa memorialista vai além das experiências do eu-narrador, por abarcar um leque maior em termos de enfoque. Assim, de acordo com as ocorrências literárias mais freqüentes, se a autobiografia está centrada no indivíduo e na sua própria história, o gênero memória se expande mais, partindo do eu (subjetivo) para o mundo da referência (objetivo).

Para analisar a natureza autobiográfica, presente ou não nos textos em estudo, é imprescindível trazer aqui a abordagem de Mikhail Bakhtin, que desloca o foco da pergunta norteadora do deslanchar da narrativa de "Quem sou eu?" para "Como eu represento a mim mesmo?". Bakhtin afirma que o texto autobiográfico não deverá se compor por um aglomerado de informações sobre si mesmo, atendendo a fins práticos, mas sim alcançar os valores artísticos da elaboração biográfica ou autobiográfica. Os elementos biográficos numa obra podem se diversificar muito, podem apresentar caráter confessional, informativo de fins práticos e objetivos ou lírico, mas eles só serão interessantes do ponto de vista artístico-literário se apresentar os valores biográficos. Devido à amplitude e complexidade do mundo biográfico e seu contexto axiológico, Bakhtin distingue dois tipos de valores biográficos: os aventuresco-heróicos e o social-de-costumes. Os valores biográficos do primeiro tipo têm por base os seguintes elementos: a) a vontade de se destacar no mundo dos outros, apresentando as peculiaridades de um herói; b) o anseio de ser amado; c) o desejo de superar a fabulação da vida. 0 segundo tipo de valores biográficos - social-de-costumes - apresenta dois planos caracterizadores: a) "o próprio herói-narrador, representado do interior na forma como vivenciamos a nós mesmos no herói dos nossos sonhos e lembranças, é francamente identificado com os outros que o rodeiam"; b) "as outras personagens; 
em sua representação há muitos traços transgredientes; elas podem ser não só caracteres, mas até mesmo tipos..." (BAKHTN, 2003, p. 140-50). Bakhtin ao tratar dos valores biográficos não distingue a abordagem biográfica da autobiográfica.

Para Bakhtin, a autobiografia apresenta-se firmada na região fronteiriça entre a expressão do "eu" (o autor) e a expressão do personagem (o herói). $\mathrm{Na}$ autobiografia ocorre, então, a "auto-objetivação", isto é, há a contraditória coincidência entre a personagem e seu autor. $\mathrm{O}$ aspecto contraditório está no fato de que "o autor é o elemento do todo artístico e como tal não pode coincidir dentro desse todo com a personagem, outro elemento seu" (BAKHTIN, 2003, p. 139). A história de vida só pode ganhar "unidade biográfica axiológica" quando o eu narrador tomar para si como conhecimento seu, as palavras de pessoas íntimas, as quais são incorporadas à sua narração, trazendo consigo muitas vezes a "tonalidade emocional" com as quais Ihes fora apresentada. O "eu" narrador utiliza de todos os acontecimentos de fundamental importância para construir a sua história, não percebida ou presenciada por ele, que em muitos casos era uma criança em tenra idade, como os fatos relacionados ao seu nascimento, à vida familiar, e à nacional. Assim os acontecimentos não vivenciados pelo narrador são incorporados à narrativa através da memória das outras personagens. A posição axiológica do outro pode ser adentrada por mim através das demais personagens que compuseram a narrativa de minha vida. Desse modo é o mundo dos outros que torna produtiva a "a auto-objetivação biográfica", revestindo-a de autoridade. Torna consistente em mim a posição do outro, enquanto autor de minha vida, demarcando assim o distanciamento de mim mesmo que é sustentado, justamente, pelo atraente mundo dos outros, ao qual me mantenho ligado sem me contrapor. A "Força e o poder do ser axiológico da alteridade, da natureza humana estão em mim, não de uma natureza bruta e indiferente e sim sancionada axiológicamente e informada em mim mesmo..."( Idem, p. 142). Ao narrar a própria existência, o sujeito institui a si mesmo, possibilitando, assim, a construção de sua consciência de estar no mundo. A autobiografia é fruto da relação da expressão literária com os aspectos íntimos e cotidianos da existência. Visa recuperar "a espessura existencial da vida cotidiana, tentando surpreender, na experiência de cada dia, aqueles momentos de resistência do vivido, da insurgência da beleza e da verdade, capazes de dissolver os vínculos da rotina" (STADNIKY, 2008, p. 2). 


\subsection{Do romance ao Künstlerroman}

Aproximadamente 15 anos após conceituar e definir a autobiografia pela primeira vez, Philippe Lejeune (em 1986) alerta aos leitores para o fato de que, conforme os caminhos trilhados pela produção literária de natureza intimista, houve quase uma fusão entre o romance autobiográfico e a autobiografia, trazendo, assim, para a problemática da crítica literária a dificuldade em discernir os traços definidores dessas duas formas de abordagem do "eu": "nos últimos 10 anos da 'mentira verdadeira à ficção', o romance autobiográfico literário aproximou-se da autobiografia a ponto de tornar mais indecisa do que nunca a fronteira entre esses dois campos" (Lejeune, 2008, p. 59). Possivelmente, a dúvida de Lejeune tenha se intensificado não só pelas novas peculiaridades apresentadas pela escrita confessional contemporânea, mas especialmente pela sua maturidade intelectual, constituída à medida que o seu período de estudos dedicado à autobiografia foi se expandindo. O referido pesquisador continuamente busca o seu antigo propósito de redefinir o conceito de autobiografia. No colóquio Autobiografia, Auto-representação, ocorrido na Faculdade de Letras de Lisboa, em dezembro de 2002, Lejeune ressalta que, nessa busca pela constituição e estudo do gênero autobiográfico, o que há de mais prazeroso de todas as descobertas são as situações fronteiriças constatadas, isto é, "quando um gênero usa de maneira figurada ou ficcional traços do gênero oposto (autobiografia na terceira pessoa, memórias imaginadas, autoficções...)" (2003, p. 38).

Se considerarmos a abordagem de Lejeune no que se refere ao contrato biográfico, ancorado na identidade "autor-narrador-personagem", os textos analisados apresentam mais peculiaridades que o definam como romance que como autobiografia. Considerando a abrangência da abordagem em que o "eu" trata de sua intimidade, envolvendo todo um contexto mais amplo que compõe um universo, traços do gênero memorialísticos, em Percursos e em $O$ berro, também comporia a mistura de sua constituição enquanto gênero. Diante dessa constatação é imprescindível que se efetive uma reflexão sobre a plasticidade do romance, gênero, cuja natureza coincide com a mobilidade da estrutura base da sociedade burguesa. 
Quando se subtrai a polêmica dualidade realidade-ficção, a autobiografia é um gênero literário similar ao romance por centrar especificamente na figura do indivíduo, elemento característico do sistema capitalista. A partir das observações de Walter Benjamin, em seu texto "O Narrador", pode-se notar que o gênero romanesco tem por elemento básico o indivíduo em situação de isolamento. Assentado na proliferação do livro através do desenvolvimento da imprensa, 0 romance é produzido pelo escritor segregado em seu mundo que no ato de sua criação e tem como receptor o leitor confinado na sua individualidade (BENJAMIN, 1994, p. 200). Nesse sentido, Bakhtin pondera que, dentre os grandes gêneros, o romance é o único cujo nascimento é posterior ao desenvolvimento da escrita e do livro. O romance está para a modernidade da mesma forma que a epopéia está para o mundo antigo. O gênero romanesco ainda está em fase de constituição, sua estrutura não consolidada se caracteriza pela plasticidade. É um gênero capaz de se ajustar às transformações do mundo atual e aos novos paradigmas constituídos. "O estudo dos outros gêneros é análogo ao estudo das línguas mortas; o do romance é como o estudo das línguas vivas, principalmente as jovens". Em constante evolução, o gênero romanesco torna-se difícil e complexo de ser definido e teorizado pelos seus estudiosos. Contrapondo a relação harmoniosa com que se apresenta os outros gêneros da tradição poética, o romance parodia os e os reinterpreta, além de Ihes imprimir novos aspectos literários. Com a ascensão, o romance estabelece uma relação problemática e conflituosa com os outros gêneros, o que propicia à literatura, em sentido amplo, passar por um processo de transformação. Assim, aqueles gêneros que na sua pureza guardavam seus cânones romancizam-se, através da estilização, são parodiados e travestidos de faces nunca assumidas antes. Adquirem então aspectos menos rígido, com mais mobilidade, sua linguagem se renova graças ao plurilingüísmo.

$\mathrm{Na}$ abordagem bakhtiniana, o nascimento do romance se dá a partir da paródia, da sátira e da estilização dos gêneros, enfim, da carnavalização dos gêneros oficiais. O romance moderno é, então, um gênero híbrido. Diferente da origem de outros gêneros, ele surgiu em circunstância de intensificação do plurilinguísmo. O gênero notório e delineadamente "sério", caracterizado pela rigidez estrutural, constituída ao longo dos séculos, ao se encontrar travestido de outras tonalidades antes inexistentes, é, assim, atingido pelo riso, pelo humor, pela ironia. 
Há, então, a dessacralização dos grandes gêneros e o principal propiciador dessa eventualidade de natureza ampla na literatura é o romance.

Por constituir-se como um gênero da expressão literária do sistema capitalista em que os valores morais, religiosos e estéticos estão em um constante vir a ser, em que nada é dado como concluído, o romance traz como problemática literária a questão do "inacabamento semântico específico e o contato vivo com o inacabado, com a sua época que está se fazendo (o presente ainda não acabado)" (BAKHTIN, 2002, p. 400). Por estar vinculado ao presente inacabado, o romance não se deixa enrijecer enquanto estrutura constitutiva. Gravitando em torno do incompleto, o romancista pode emergir no campo da representação em diversas maneiras: "pode representar os momentos reais da sua vida ou fazer uma alusão, pode intrometer na conversas dos personagens, pode polemizar com seus inimigos literários, etc" (Idem, p. 417). Assim, o romance pode ser considerado um "gênero acanônico" cuja natureza se define pela plasticidade e que está em constante procura de elementos novos, mas sem deixar de reconsiderar todas as formas adquiridas.

Apesar da proximidade que há entre a natureza das obras em estudo e o gênero autobiográfico ou mesmo o gênero de memória, entende-se que em $O$ berro e Percursos, o que predomina na sua essência constitutiva são os traços do gênero romanesco. E para melhor entender a situação de fronteira entre o ficcional e o confessional em que se encontram os textos analisados e considerando que ambas as narrativas focalizam a história de vida de suas protagonistas cuja formação incluem de certa forma o nascimento delas como escritoras, como artistas da palavra, faz-se importante fazer referência ao Künstlerroman ("romance da artista").

Semelhante ao gênero autobiográfico, o Künstlerroman é um gênero que começa a fazer parte da tradição literária ocidental a partir do século XVIII. Sabe-se que sua natureza apresenta características muito próximas ao Bildungsroman - isto é, no romance de formação - que tem como modelo primeiro o conhecido romance de Goethe, O Aprendizado de Wilhelm Meister (Wilhelm Meisters Lehrjahre, 17951796). Esta abordagem terá como amparo teórico o estudo de Eliane Campello (2003, p. 15-100).

As ações do Bildungsroman voltam-se para o processo de desenvolvimento interior do protagonista em confronto com os acontecimentos externos que compõem o mundo e o meio onde se encontra inserido. Esse gênero 
romanesco versa sobre o conflito entre o "eu" e o mundo e, assim, "dá voz ao individualismo, ao primado da subjetividade e da vida privada perante a consolidação da sociedade burguesa, cuja estrutura econômico-social parece implicar uma redução drástica da esfera de ação do indivíduo". Segundo Luísa Maria Rodrigues Flora, o Bildungsroman pela relação estabelecida com o tempo na narrativa e pela abertura estabelecida no final da narrativa apresenta-se muitas semelhanças com a autobiografia. De acordo com L. Köhn, este gênero romanesco se distingue da autobiografia pelo "seu grau de abstração da realidade, favorecendo aquilo que é universal no ser humano". Para Capello, Künstlerroman apesar de compor-se de algumas características em comum com o Bildungsroman, é um gênero autônomo (2003, p. 32 e 66). Os dois gêneros possuem aspectos em comum com a autobiografia, com a obra de memória e com o romance de confissão. Sabese que ao longo da história os diversos gêneros literários e, neste caso, os gêneros narrativos sempre foram estudados e definidos pelos críticos e teóricos a partir de determinados parâmetros estabelecidos. Tendo em vista essa constatação, sabe-se que os parâmetros definidores do Künstlerroman partem de um paradigma androcêntrico. Desse modo por muito tempo esse gênero sempre foi reconhecido e definido pelos estudiosos da literatura somente quando sua narrativa girava em torno da formação de protagonistas masculinos. Assim aquelas narrativas dessa natureza cuja personagem eram mulheres eram descartadas e desqualificadas pela crítica por não se enquadrarem dentro dos parâmetros instituídos (BALEY, 2005, p. 2-3). Tratam-se, então, de parâmetros androcêntricos só vão ser questionados a partir da década de 1970 com o despontar da crítica literária feminista. Desse modo, só a partir desse momento é que Küntlesrroman de autoria feminina começa a ser estudado em todas as suas peculiaridades.

O teor desse gênero romanesco é constituído pelo processo de formação espiritual, social e psicológica da personagem principal da obra e os acontecimentos abordados compreendem o período que vai da infância ao começo da vida adulta da protagonista. Já o Künstlerroman, o romance do/a artista, centra em torno da formação de uma personagem principal que desempenha atividades artísticas como escritor, poeta, músico, ator, etc.

Como as narrativas de Albues e Wanda Ramos centram em eventos de suas vidas de ordem íntima, pessoal da infância até parte da vida adulta e não apenas em sua formação como escritoras, pode-se considerá-las mais como 
romance de caráter confessional e autobiográfico, levando-se em conta que os mesmos são constituídos de um misto de ficção e recriação da realidade. Nenhuma das autoras assume diretamente na obra que esta se refere unicamente às suas experiências de vida. Por esse detalhe, com base na definição primeira do conceito de autobiografia elaborado por Philippe Lejeune e pela presença forte do imaginário na construção dos textos, mesmo que eles tenham semelhanças com o percurso de vida das autoras, não é possível defini-los como autobiográficos.

O estudo de Capello nos ajudará a desenvolver determinadas reflexões a respeito dos elementos e problemas literários das obras em estudos que têm correspondência com o gênero Küntlesrroman, como por exemplo o teor metanarrativo presente nas mesmas. Como já foi feita referência, há numerosas passagens tanto de uma obra quanto na outra que tratam especificamente do papel da protagonista como escritoras especialmente do processo inicial da surgimento como tal.

Entre as passagens que tratam da formação das protagonistas como escritoras e/artistas e as que constituem relatos das suas experiências de vidas íntimas e sociais das personagens, são as últimas que ganham maior força dentro do texto, ou seja, as duas coexistem com predomínio das características autobiográficas. Mas se o leitor analisar que os elementos autobiográficos contém muito do ficcional e do imaginário para dar corpo e unidade às narrativaa, é possível afirmar que as referidas obras constituem uma mistura de autobiografia e memória com traços peculiares ao romance da artista. Todas essas características mescladas, cada uma na sua proporção, perdem em intensidade para o ficcional quando individualizadas. Neste caso, o ficcional é componente preponderante na constituição dos textos em estudo, até porque quem conta um fato ou experiência o faz através de elaborações discursivas próprias, as quais têm em vista não o compromisso com a fidelidade ao real, mas o olhar, a perspectiva do sujeito que fala, constituindo, assim duas obras do gênero romanesco.

\subsection{Rememorarar: do fluxo da consciência ao discurso indireto livre}


No intuito de acompanhar os processos mentais da consciência ocorridos no ato da rememoração, a arte de narrar lança mão do fluxo da consciência enquanto procedimento do discurso literário, em que há uma espécie de ausência da disposição lógica a que era submetido o fluxo do pensamento, transmitido conforme os moldes tradicionais. Assim, está estruturada a narrativa de Albues, pois sua narradora revela-se em muitas passagens da obra determinada despreocupação com a ordem espaço-temporal ao fazer o uso do artifício narrativo fluxo da consciência que, juntamente com a presença forte do imaginário, produz no texto certo ar de estranhamento, uma espécie de caos a quebrar a forma tradicional.

No contexto conturbado do mundo moderno as novas gerações de escritores encontraram no irlandês James Joyce a fonte de inspiração para uma leva de produções que revolucionasse o mundo da ficção literária. Joyce não nega a tradição, mas digere-a para, a partir daí, abrir caminho para uma produção literária que revolucionasse as novas gerações de escritores. E o que vai definir a sua produção nesse sentido vai ser a sua adoção, como técnica narrativa, do fluxo da consciência. O retrato do artista quando jovem é o primeiro romance em que Joyce adota o fluxo da consciência, mas é na construção da narrativa de Ulisses, publicado em 1922, que essa técnica chega ao seu ápice na elaboração artística do referido escritor.

Grande número de escritores admiraram a nova técnica narrativa do fluxo da Consciência. Na França essa técnica literária baseada nos processos mentais tem em Marcel Proust um dos seus maiores expoentes literários com a extraordinária obra, já referida nesta pesquisa, Em busca do tempo perdido ${ }^{10}$. Na Inglaterra, a romancista e critica literária Virginia Woolf (1882-1941) lança mão da técnica do fluxo da consciência e do estilo poético na produção de seus textos, contribuindo assim de modo representativo para a constituição da ficção modernista e contemporânea.

O impacto de seu uso foi muito representativo: disseminando-se entre os autores de seu tempo, o seu uso avançou para outros períodos que sucederam ao modernismo e é ainda muito utilizado pelos autores contemporâneos. No Brasil

\footnotetext{
${ }^{10}$ Obra escrita no período de 1908-1909 a 1922 e publicada entre 1913 e 1927. Constituída por sete volumes é um relato com traços de cunho pessoal e autobiográfico em que o narrador Marcel desfia suas rememorações da infância até a vida adulta.
} 
deparamos com a significativa presença de escritores importantes que fizeram hábil uso da referida técnica como Clarice Lispector e Pedro Nava, entre outros.

Se o fluxo da consciência é um recurso da narrativa que melhor representa os processos mentais isentos da elaboração do raciocínio lógico, quebrando assim as fronteiras que separam os acontecimentos narrados com base na ordem cronológica, o discurso indireto livre é uma estratégia discursiva em que são diluídas as fronteiras que separam as vozes dos personagens e do narrador nas duas narrativas e está presente tanto na narrativa de Albues quanto na de Wanda Ramos.

A respeito dessa técnica, Bakhtin, o expressivo teórico da linguagem do dialogismo e da polifonia, fornece a este estudo uma compreensão muito importante: o narrador contemporâneo, muitas vezes com o interesse de dar voz ao personagem através da atenuação das fronteiras do discurso citado e de peculiaridades que são próprias de seu temperamento como o humor, o sarcasmo, a ironia e até seus sentimentos, opta pela técnica narrativa do discurso indireto livre. Outras vezes o narrador, querendo esvaziar-se de todo teor autoritário ideológico e de dar fluidez a sua voz, assume para si a linguagem das personagens componentes da narrativa.

Para o filósofo da linguagem o enfraquecimento do uso da forma racional e dogmática de citar a palavra de outrem acontece no neoclassismo e na elaboração dos gêneros menores. Nesse sentido o discurso indireto livre só vai se desenvolver com maior precisão nas fábulas e contos de La Fontaine. (BAKHTIN, P. 150-4). O discurso indireto livre estabelece o evento mais relevante e sintaticamente mais bem definido "de convergência interferente de dois discursos com diversa orientação do ponto de vista da entoação" (BAKHTIN, 1986, p. 170). Na sua abordagem sobre o referido tema, Bakhtin se baseia em outros pesquisadores como o alemão Eugen Lerch para quem, na comparação entre os discursos direto, indireto e indireto livre, este último é o que mais aproxima da realidade e no que se refere aos aspectos estilísticos trata-se de um discurso que melhor produz um efeito "vívido e concreto". Apoiado nos estudos de Lork publicados em 1921 (Die Erlebte Rede = O "Discurso Vivido") na qual versa sobre o discurso indireto livre como um "discurso vivido", Bakhtin entende que ele se configura como uma maneira direta da apreensão do discurso de "outrem", do vívido, efeito produzido por este que serve em especial às representações do tipo literário, em que o seu valor estilístico é grande. $O$ artista, em seu processo de criação, vê e ouve seus fantasmas como a própria realidade. $\mathrm{E}$ 
assim, ele não lhe entrega a palavra como se faz no discurso direto: ele os ouve falar. Essa situação de impressão viva constituída pelas vozes ouvidas pelo artista só poderá manifestar-se através do discurso indireto livre (Idem, p. 182).

Nesse sentido, pode-se observar que o valor estilístico da representação literária do discurso indireto livre é expressivo, dá ao discursos de "outrem" uma vivacidade muito importante para se trabalhar com o imaginário. Por isso Bakhtin afirma que essa forma de representação de apreensão do discurso de outrem aparece em primeiro momento para representar o mundo maravilhoso recriado por La Fontaine.

Realizando um retrocesso no percurso histórico, especificamente tratandose das construções discursivas no francês, no final da Idade Média, o autor não se vê mais mergulhado no mundo dos sentimentos experimentados por seus personagens, pois, em termos de concepção de mundo e de homem o sentimento é substituído pela razão. Assim na abordagem dos historiadores, o "presente histórico" se faz raramente presente, tendo em vista a presença predominante do tempo passado delimitando um afastamento considerável entre 0 tempo dos acontecimentos e o tempo da enunciação. O ponto de vista do narrador passa neste momento a se distinguir objetivamente da voz dos personagens. $E$ a transmissão da voz de outrem se faz de forma "impessoal e sem cor, e a voz do narrador abafa a do enunciador". Trata-se então de um período de despersonalização do discurso, que é sucedido pelo individualismo característico do Renascimento, no qual há então uma proximidade entre o narrador e seu herói. (Idem, p. 186).

Contrariando a esse irracionalismo lingüístico que distinguiu as produções literárias do Renascimento, no século XVII, passam a estabelecer regras rígidas quanto ao uso dos tempos e modos do discurso indireto. Exigem-se que se estabeleça um equilíbrio entre a objetividade e subjetividade do pensamento transmitido. A análise objetiva e a representação das manifestações pessoais apresentam-se de forma harmoniosa e equilibrada na narrativa.

O discurso indireto livre surge num contexto gramatical que the é favorável. Como já foi observado, ele aparece primeiro em La Fontaine, em cujas narrativas mantém o equilíbrio entre o subjetivo e o objetivo peculiar ao neoclassicismo. De um lado há a supressão do verbo introdutório que leva o narrador identificar-se com o herói, de outro, o uso do tempo imperfeito em oposição ao presente do discurso direto e a escolha do pronome dentro dos parâmetros do 
discurso indireto que dão ao narrador determinada autonomia por impedi-lo de diluirse inteiramente na atividade mental do seu personagem. Constatação esta muito relevante para o estudo das duas obras em análise, considerando que ambas contém fortes traços autobiográficos: no texto de Wanda Ramos, como já referido anteriormente, a voz do narrador em terceira pessoa em muitos momentos se confunde com a da heroína e na de Albues a voz na narradora adulta inúmeras vezes é invadida pela perspectiva dela mesma quando era menina, já que a narrativa focaliza em especial sua fase de criança. Entender as razões que levaram o pai da fábula moderna e outros escritores a optarem pelo discurso indireto livre contribui para o esclarecimento dos efeitos causados, em termos de verossimilhança, deste procedimento discursivo utilizado nas narrativas em estudos.

Esse procedimento discursivo adquire em Flaubert maior complexidade. $\bigcirc$ discurso indireto-livre the permite ora aproximar de suas personagens, identificar-se com elas, ora distanciar-se de suas criações mantendo-as autônomas. O discurso indireto livre adquire sentidos expressivamente antagônicos e incoerentes em relação a sua própria postura, em relação a si mesmo e as suas criações, na medida em que ele oscila entre o amor e o ódio por seus heróis. Nesse sentido, Bakhtin ainda ressalta que talvez tenha sido o uso do discurso indireto livre que tenha possibilitado ao mestre do realismo, no período do lançamento e sucesso de seu romance Madame Bovary, a possibilidade de se defender da acusação de defesa do adultério no romance: ao mesmo tempo que argumentara que o ponto de vista expresso no discurso não era o seu, dizia que o personagem Emma Bovary era ele próprio. Desse modo, recursos expressivos do discurso indireto livre viabilizam ao romancista identificar-se com seus personagens e ao mesmo tempo manter certa autonomia e distanciamento delas.

Em se tratando da inter-relação entre o discurso narrativo e o discurso citado, Bakhtin pondera que o discurso indireto livre não manifesta uma impressão passiva por meio da enunciação de outrem, mas sim uma orientação ativa. Esse tipo de citação da palavra do personagem não se reduz à passagem da primeira pessoa do discurso direto para a terceira do discurso indireto, mas acrescenta à enunciação citada a entoação do narrador mesclada à entoação da voz da personagem que acaba por interferir naquela. Dando continuidade, o discurso direto simples não capta com mais perfeição a natureza do discurso de outrem. O que ocorre é que todo tipo de transmissão da voz de outrem o faz como uma forma ativa de expressão 
da voz do outro. Todo valor inerente à palavra citada está não no significado isolado do discurso, mas especialmente na entoação e acentuação expressivas da enunciação. O sentido do discurso para se constituir precisa se ancorar na sua acentuação e na sua entonação expressa.

Outro ponto de destaque no uso do discurso indireto livre está relacionado a sua adoção por parte de grandes escritores que o fazem com freqüência e habilidade para atender a um quesito da realidade literária que prioriza a leitura silenciosa. (Bakhtin, 1986, p. 188-92).

Sabe-se que o surgimento e desenvolvimento do discurso indireto livre apresenta profunda relação com processo de desenvolvimento de outras variantes expressivas dos discursos direto e indireto. Ele é uma revolução grandiosa no processo de desenvolvimento social da enunciação, considerando que o discurso indireto livre tem papel preponderante no desenvolvimento das línguas européias contemporâneas (BKHTIN, 1986, p. 195).

\subsection{Subjetividade: relações dialógicas}

O mundo é apreendido pelo sujeito historicamente e socialmente. $\mathrm{Na}$ perspectiva bakhtiniana, sujeito se constrói discursivamente, a partir das infinitas vozes que constitui a realidade social na qual está inserido e a partir de suas interrelações dialógicas estabelecidas com essas vozes. Graças à multiplicidade de relações estabelecidas de concordância e discordância de "outrem" o sujeito absorve uma variedade de outras vozes que também estão e intensa e constante relações entre si:

a condição da enunciação, em Bakhtin, é afetada pela ordem social e histórica. Ela é uma réplica do diálogo social. Portanto a consciencia individual é reflexo de uma consciencia social. A subjetividade só pode ser social e histórica e dependente das práticas discursivas (ELICHIRIGOITY, 2008: 201).

Nesta perspectiva, o sujeito não é um ser passivo consubstanciado pelas estruturas sociais e nem um ser disjunto, desconexo que se compõe à revelia da sociedade. A gênese do sujeito está no seu agir, considerando que o seu ser depende da sua ação com os "outros", isto é, da sua interação com o "outro". Assim, 
ele participa desse eterno vir a ser, considerando que o seu interior é composto por diversas vias de mão dupla com o exterior, composto pela diversidade, pelo inacabado, pelo constante inovar. Desse mdo, a subjetividade se faz a partir de um processo dialógico do sujeito com o meio onde está imerso.

Para melhor entender o processo de rememoração constituído em que o "eu" é, numa visão imediata, sujeito e objeto da enunciação é imprescindível entender a questão da subjetividade, constituída na relação continua e dialógica do "eu" com os "outros". Com base no dialogismo, pilar fundamental da abordagem teórica de Bakhtin, a unicidade do sujeito e seu discurso são questionados em favor de um "eu" heterogêneo, pois até ,mesmo a percepção que o "eu" tem sobre si é desenvolvida através do "outro".

Na frase "Vejo-a se debater numa gaiola..." (BCN, p. 161), a narradora de Albues fala de si mesma enquanto personagem, e o distanciamento existente entre o sujeito e o objeto da enunciação, demarcado especialmente pelo tempo que passou, torna bastante evidente a intersecção da voz de "outrem" com a voz do "eu" que narra, constituída no suceder das relações intersubjetivas durante sua existência, assinalada pelas diversas experiências de vida.

No caso da autobiografia,o "eu" narrador precisa posicionar-se axiologicamente diante da própria vida, distanciando-se dela, olhando a vida de fora, de modo a tornar-se um "outro" diante das próprias experiências lembradas, o que vai the permitir a auto-objetivação, olhar-se com um "excedente de visão e conhecimento" (BAKHTIN, apud FARACO, 2008, p. 43).

O uso do discurso em terceira pessoa na narrativa de Percursos mediando a voz da protagonista possibilita a existência freqüente de passagens em que a expressão daquele que narra aparece repleto de sinais da presença da voz do "outro", isto é, o discurso do narrador volta e meia é invadido pelas expressões e outras marcas das falas das personagens que compõem o enredo. $O$ uso freqüente nas duas obras do discurso indireto livre também assinala as marcas de outros discursos no discurso daquele que se propõe a fazer o uso da palavra. Trata-se de uma situação que aparece com mais freqüência na narrativa de Wanda Ramos.

Sabe-se que o sujeito só se define através das relações estabelecidas com os demais sujeitos; consequentemente, a autoconsciência só é desenvolvida mediante a atuação do "outro" junto ao "eu". Compreender o papel do signo lingüístico nas relações interpessoais é, na concepção de Bakhtin, imprescindível 
para se estudar como se processa a construção da subjetividade. A linguagem é um elemento fundamental para que o sujeito interaja continuamente com os diversos componentes de sua cultura. E, como a formação da subjetividade se efetiva com base nessa interação, a linguagem se configura e ocupa lugar prioritário na constituição do sujeito. Os signos refletem e refratam a realidade social. Se de um lado todo signo é ideológico, não é possível existir uma ideologia sem signo. Tecida da substância viva da ideologia, a palavra fornece indícios expressivos de toda e qualquer transformação social (1986, p. 41). Bakhtin ressalta que "cada palavra se apresenta como uma "arena em miniatura" onde se entrecruzam e lutam os valores sociais de orientação contraditória. A palavra revela-se, no momento de sua expressão, como o produto da interação viva das forças sociais". (Idem, p. 66)

A construção do discurso pelo "eu" se dá mediante a interação real ou mesmo imaginária com os discursos de "outrem". Se todo discurso é constituído a partir do encontro de diversas linguagens de inúmeras maneiras, a constituição do "eu" se efetiva a partir das relações intersubjetivas. Desse modo, o sujeito "é dialógico e seu conhecimento é fundamentado no discurso que ele produz" (MARQUES, 200... p, 3). Por razões como essas, não é possível analisar o sujeito como algo pronto e definido. $\mathrm{O}$ "eu" não é estático, mas sim inacabado em constante processo de construção; sua natureza se define pela eterna busca de "completude inconclusa". Se de um lado a unidade subjetiva é dada, de outro, ela se coloca constantemente em aberto, é incompleta.

A relação dialógica entre o "eu" e o "outro" tem por base três formas de vinculação fundamentais: o "eu-para-mim", "eu-para-o-outro" e o "outro-para-mim" (BAKHTIN, 2003, p. 3-90). A primeira diz respeito à representação que o "eu" faz de si mesmo; a segunda refere-se a representação que o "eu" faz de si a partir da visão do "outro" e, por último, a terceira refere-se a representação que o "eu" faz do outro.

Bakhtin "relativiza" toda perspectiva apresentada pelo indivíduo:

Quando nos olhamos, dois diferentes mundos se refletem na pupila de nossos olhos. Assumindo a devida posição, é possível reduzir ao mínimo essa diferença de horizontes, mas para eliminá-la inteiramente urge fundir-se em um todo único e tornar-se uma só pessoa. [...] $O$ excedente de minha visão em relação ao outro indivíduo condiciona certa esfera do meu ativismo exclusivo, um conjunto daquelas ações internas ou externas que só eu posso praticar em relação ao outro, a quem elas são inacessíveis no lugar que ele ocupa fora de mim; tais ações completam o outro justamente 
naqueles elementos em que ele não pode completar-se (2003, p. 2123).

A visão do sujeito é constituída a partir do lugar e do tempo ocupado por ele, e é de acordo a sua localização estabelecida que o indivíduo vê o que está fora do campo de visão do "outro" e este "outro" sempre verá algo não visto pelo sujeito.

Bakhtin em sua abordagem sobre o sujeito não se opõe à concepção de memória trabalhada por Halbwachs, um dos principais teóricos que fundamentam essa pesquisa. Tanto para aquele quanto para este a visão do "eu" é constituída através da relação com o "outro", isto é, com o social. O que há entre as duas abordagens são enfoque distintos, mas que se complementam como base teórica na fundamentação desta pesquisa.

Analisando a concepção de Bakhtin sobre a formação da consciência do indivíduo, pode se perceber que nesta perspectiva a memória não se refere apenas a um processo desenvolvido nas estruturas cerebrais. O fenômeno mnemônico se constituiria através das relações sociais mediante ao uso da linguagem. "Portanto, a memória é um fenômeno que estaria estreitamente relacionado ao processo de significação da língua” (VLIESE, p. 13). Rememorar é, então, fazer uma leitura do passado em que "a imagem mental do passado é traduzida por palavras que tem seu significado construído" (Idem, p. 15). Cada pessoa realizará uma leitura diferente de um único fato passado, a qual condiz com as suas condições subjetivas, condições essas consubstanciadas nas relações sociais estabelecida pelo "eu".

\subsection{Subjetividade e memória}

Narrar as experiências pessoais é algo que faz parte do cotidiano do ser humano tanto quanto seu desejo de preservar a própria vida, mas é a partir da sociedade burguesa centrada na figura do indivíduo que os textos de índoles confessionais ganham maior representatividade. O indivíduo ao contar sua história, o faz conforme as interpretações que realiza das lembranças que consegue evocar voluntária ou involuntariamente de suas experiências vividas. A interpretação do passado e a forma como narra as experiências são condizentes com a visão que o sujeito tem do mundo e de si, não do tempo dos acontecimentos relatados, mas do tempo da narração. A narrativa se desenvolve de acordo com o que ele, sujeito do 
discurso e das ações enquanto personagem, não só acredita sobre si, mas especialmente deseja que os leitores entendam e saibam sobre sua vida. Por essas observações percebe-se a forte relação que há entre a memória e a ficção.

A subjetividade, traço balizador do discurso memorialístico, é um dos principais elementos definidores da natureza ficcional de uma obra. A ficcionalidade no texto de memória também vai ser definida pela ligação que há entre as lembranças e as emoções sentidas pelo sujeito que lembra. A intensidade das emoções vai assinalar a relevância dos acontecimentos na memória do indivíduo.

Ao longo da existência, o sujeito vai se transformando e essa transformação constante está intimamente ligada ao social, o que contribui para que a história de vida tenha sabor em ser narrada. Nada de poético e interessante haveria de se contar, se a história de vida fosse uma série de acontecimentos repetitivos, ou se o protagonista-narrador tivesse um perfil único do começo ao fim da existência. Alguns traços marcantes conservados ao longo da vida delimitam e definem a essência de nosso ser, mas determinadas características vão ganhando novos contornos, se modificando, conforme as inúmeras situações vivenciadas, e dando ao sujeito diferentes facetas, assumidas por ele nas várias fases da sua existência, o que resultará nas diversas formas do sujeito se colocar e agir no mundo.

Analisando a perspectiva de Sarlo, é imprescindível observar que toda constituição do eu psíquico perpassa pela relação do eu com o outro, assim como acontece em Bakhtin. É no espaço de cruzamento do individual com o coletivo e social onde a subjetividade e a objetividade se integram num só corpo e aquilo que era particular de um "eu" único pode tornar se universal. Antonio Candido afirma que o poeta ao inserir seu o "eu" no mundo na constituição do texto autobiográfico é capaz de revelar, através de manifestações particulares, aspectos universais. Há uma transcendência do particular, e o individualismo peculiar ao discurso autobiográfico ganha dimensões objetivas, de mundo. O "Narrador"11" insere a si próprio na trama do mundo: a experiência pessoal narrada se confunde com as experiências de cunho coletivo, mas sem perder o individual que é o condutor da perspectiva em que o mundo é mostrado. Nesse sentido o melhor seria argumentar que o mundo é recriado através da perspectiva do indivíduo que lembra e narra.

\footnotetext{
${ }^{11}$ Antonio Candido ao referir-se ao Narrador de memória o faz iniciando a palavra como letra maiúscula.
} 
As memórias ganham contornos universais por permitirem ao indivíduo que lembra sair do seu isolamento, escapar ao liame do pessoal e enxergar-se como uma unidade íntegra, mas que compõe um todo maior, o universo. A história do "Narrador" é simultânea a de seus contemporâneos. A narradora de Tereza, ao falar das suas experiências de menina pobre no final da segunda metade do século $X X$ dá ao leitor pistas de como se perfilava a realidade mato-grossense para uma determinada classe social. $E$ do outro lado do oceano, as reminiscências da protagonista de Wanda Ramos, mediadas pelo narrador em terceira pessoa, assinala como pode ter sido a vida de muitas meninas brancas, filhas de portugueses colonizadores no período da colonização Portuguesa e também da Guerra Colonial em Angola.

$\mathrm{Na}$ abordagem autobiográfica, o "eu" que narra busca dar unidade a percepção que tem de si próprio, reconstruindo o percurso de sua existência usando do imaginário do ficcional para preencher as lacunas deixadas pelo esquecimento. $A$ narrativa lhe permite, então, dar unidade a todas as lembranças de seu passado, cuja representação, quase sempre, lhe vem de forma fragmentada. Para Mara Eugênia Dias de Oliveira, no texto de natureza autobiográfica "a descrição dos fatos faz-se na perspectiva do sujeito, as instâncias objetiva e subjetiva dissolvem-se na trama da narrativa" (1982, p. 149).

A sociedade contemporânea vive um momento de intensa subjetividade. E, de acordo com Beatriz Sarlo (2005, 20-1), o texto de cunho pessoal, neste caso a literatura de testemunho, tem como foco não a simples intimidade do eu narrador, mas especialmente a esfera da manifestação pública. Nessa abordagem fala-se do enfraquecimento da autoridade do passado sobre o presente. É o novo que se impõe ao velho por sua natureza libertadora intrínseca. Aquilo que aconteceu com a arte no início do século XX, com o passar dos anos é transferido para a vida, isto é, pela forma como o homem se coloca diante do mundo e pela forma como se relaciona em sociedade. Num primeiro momento da cisão entre o velho e o novo, a subjetividade não está em jogo. "A crise da idéia de subjetividade vem de outros processos e posições, de grande expansividade para além do campo filosófico, a partir dos anos 1970" (SARLO, 2005, P. 30). O triunfo das idéias estruturalistas no território das áreas das ciências sociais, da antropologia, da teoria literária conduz o 
pensamento predominante naquele período a uma crise da subjetividade em que se estabelece "a morte do sujeito"12. Em contrapartida, há aproximadamente duas décadas atrás, constituiu-se, no campo da memória e em especial da memória coletiva uma ressurgir desse sujeito que estivera ausente do pensamento contemporâneo durante um longo período naquela época.

No ensaio “Dez problemas para o romancista latino-americano”, publicado em Havana em 1964, Angel Rama já ressalta, em seu texto sobre o romance latinoamericano, a tendência da literatura para o documentarismo, para as formas de reportagem direta, testemunhal e autobiográfica. Para o crítico, essa presença crescente e acentuada dos textos de caráter documental e autobiográfico, como fruto das revoluções e demais movimentos políticos, não era uma prioridade dos países do continente sul-americano de língua espanhola. Tratava-se, na verdade, de uma tendência da literatura de caráter mundial, proveniente das mudanças sociais rápidas e intensas ocorridas no mundo ocidental. (p.105) Para essa reflexão é relevante atentar aqui para o I Ciclo de Debates da Cultura Contemporânea, realizado em abril e maio de 1975, cujo teor dos debates apontava para a "ressurreição do sujeito". Antonio Candido (GOMES, 1988, p. 199), na mesa redonda de que participa, ao tratar das características da literatura brasileira, ressalta o "problema da dissolução da narrativa realista, ligado à crise de superação do universo referencial e à transformação das hierarquias sociais" (CANDIDO,1976). O crítico apresenta a hipótese de que a produção de um romance 'não-mimético', de narrativa fragmentada e descontínua estaria, conseqüentemente, propiciando a irrupção de uma grande leva de obras do gênero da memória. Candido conclui que todos os quesitos deixado fora do romance e do conto estavam sendo recuperado pelo texto de memória. O sucesso do gênero está firmado no freqüente desejo do leitor de "ver a literatura representar o mundo em que vivemos" (Idem). Na perspectiva apresentada, o memorialismo e a autobiografia marcam consideravelmente a prosa brasileira, produzida nos anos subseqüentes ao momento da anistia (1979) dada aos brasileiros exilados pela ditadura. Sobressai enquanto texto de memória, nesse momento, as narrativas dos exilados políticos

\footnotetext{
${ }^{12}$ Expressão que nomeia um dos capítulos do livro de Beatriz Sarlo que trata da crise da subjetividade.
} 
recém chegados ao Brasil, às quais corresponderiam ao testemunho abordado por Beatriz Sarlo.

Para Sarlo o sujeito, subtraído de cena nas décadas de 60 e 70, ressurge com todo vigor nos mais variadas modalidades do discurso: no cinema, na literatura, nas artes plásticas e na mídia. A experiência que se perdera, como abordara Walter Benjamin, ganha novamente sentido e espaço nas mais variadas formas de discursos. A intensidade com que se faz presente a subjetividade coincide com a conquista ao direito da palavra suprimido antes pela censura dos anos de repressão na América Latina como um todo. Junto com o silêncio das pessoas, imposto pelas Ditaduras nos países latino-americanos, vem também a crise identitária do sujeito muito própria dos regimes políticos repressivos estabelecido em todo o mundo ocidental em especial o nazi-fascismo.

De acordo com Sarlo, o direito ao uso da palavra e do discurso em primeira pessoa, na construção de sua história de vida, conquistados por todos aqueles que passaram pela experiência dilacerante, seria uma maneira de recuperar sua identidade fraudada pelo sistema repressor. Assim, a subjetividade marcou a pós-modernidade da mesma forma que o fim da experiência e a desconfiança caracterizou as últimas décadas da modernidade.

Neste momento não só a experiência ganha relevância como também pode ser repassada. O narrador, de posse agora da palavra e do discurso em primeira pessoa, dá sentido às suas experiências transmitindo-as ao outro. Numa espécie de resistência à alienação e à coisificação, instituídas pelos preceitos do capitalismo moderno, ao construir suas memórias o sujeito afirma-se como tal. Se a linguagem referencial predominante anteriormente não é mais capaz de dar suporte à "Verdade" do discurso ou da historia oficial, surgem então as verdades subjetivas que se afirmam aptas a revelarem aquilo que estaria encoberto pela ideologia dominante. Enquanto a "Verdade" intocável sai de cena, os sujeitos, agora reconhecidamente plausíveis e convincentes, "tornam-se cognoscíveis" (Cf. SARLO, 2007, 39).

O que se constrói agora não é mais aquele sujeito único, herói, anterior ao século $X X$, mas sujeitos múltiplos. São sujeitos plurais que ao mesmo tempo em que se transformam adaptando-se Pas novas distintas realidades, mantêm algo de essencial de sua identidade que os liga ao passado. As experiências do passado são retomadas, através das lembranças, reconstruídas no presente e, 
conseqüentemente, capazes de influir no futuro. Ao mesmo tempo em que as diferenças são aceitas por estes sujeitos múltiplos, são modificadas. Desse modo, elementos culturais e identitários contraditórios convivem entre si, libertando-se "do binarismo simples". O outro ao mesmo tempo em que é acolhido é capaz de transformar quem o recebe e também modificar-se adaptando à nova realidade. Ver Bhabha.

O pensamento que perdurou nos tempos desde o final do século $X X$, centrado na "Verdade", muda então de foco por buscar as verdades identitárias dos discursos de experiência trazem problemas não só à filosofia, mas especialmente à história. Pois, na pós-modernidade, com a não aceitação da Verdade de uma história, ganha força "a crença nas verdades históricas no plural” (Op. Cit. p. 40). Pelo que aborda Sarlo, esse paradigma da subjetividade ganha a mais alta expressão sendo bom por um lado, mas falho por outro ao propor uma "solução verbalista" a qualquer questão problemática (Idem). Observa-se então que a questão central do estudo de Sarlo é a intensidade da subjetividade presente no "temperamento" pós-moderno.

$\mathrm{Na}$ narração da experiência própria para escapar ao cotidiando das repetições e das banalidades da vida real, o sujeito precisa utilizar-se da imaginação e também da supressão e omissão dos dados e informações desnecessários ao propósito do narrador de dar unidade ao seu texto e verossimilhança.

Em "Protocolos Ficcionais", Umberto Eco fala sobre o encantamento que a ficção exerce sobre o leitor, considerando que ela "nos proporciona a oportunidade de utilizar infinitamente nossas faculdades para perceber o mundo e reconstruir o passado" (ECO, 1994, p. 137).

Segundo Beatriz Sarlo, nas últimas décadas a história se aproximou da memória e aprendeu a interrogá-la; a expansão das 'histórias orais' e das microhistórias é suficiente para provar que esse tipo de testemunho obteve uma acolhida tanto acadêmica como midiática". P. 43.

A partir do final da Segunda Guerra Mundial, a memória ocupa um espaço considerável junto às demais produções literárias, na mídia e especialmente na história, ao constituir-se como fonte dos estudo históricos e por contribuir com as mudanças das perspectivas históricas a ser instauradas na pós modernidade em que a Verdade do discurso oficial é colocada em cheque. Se a Verdade oficial é encarada agora como uma forma de interpretar o passado, a qual tem como pano de 
fundo uma ideologia, neste caso a de quem está no poder, pode então ser reconstruída com base em outros discursos. Essa forma de estudo que tem como foco a subjetividade como marca essencial do discurso memorialístico não se pode firmar na existência de uma verdade indiscutível e conclusiva. Nesse sentido, o direito de lembrar não está calcado no dever de se fazer uma afirmação verdadeira.

Há ainda a subjetividade desdobrada e a pós-memória, quando o narrador conta o testemunho que ouviu de outra pessoa. Se existe um grau de proximidade (afetiva) entre quem conta a história e quem a viveu a experiência relatada, a narrativa ganha um tom acentuado de subjetividade, distinguindo assim do relato do pesquisador, que conta também uma narrativa ouvida de um testemunho. Como não há nem uma ligação de afetividade entre o pesquisador e o sujeito das experiências, o discurso apresenta-se de forma mais objetiva que no primeiro caso descrito.

A cultura contemporânea se caracteriza pelas marcas significativas da subjetividade de quem fala ou escreve. Subjetividade esta que dá ao discurso poder de argumentação e autoridade tão elevadas que podem ser superiores aos apelos à tradição ou à veracidade factual. Cabe ao sujeito a organização do mundo e não o inverso. Segundo Contardo Calligaris, a verdade da modernidade ocidental está respaldada pela verdade oriunda da intimidade individual do sujeito que fala ou escreve. Neste sentido, o valor da arte depende de sua "conotação subjetiva, ou seja, da presença e da força expressiva da subjetividade do artista, e cada vez mais das qualidades extrínsecas do produto" (CALLIGARIS, P. 03). A "sinceridade" não está subordinada à idéia de verdade factual. Desse modo, o sujeito pode ser sincero mesmo se estiver mentindo do ponto de vista factual. Valoriza-se a intenção de sinceridade e autenticidade do sujeito, que não precisa estar atrelada à verdade factual. A observação de Clligares, num viés antropológico de sua análise, restringe a questão da subjetividade à modernidade ocidental, considerando que cada vez mais a verdade que interessa é a que está no "foro íntimo do indivíduo" do sujeito que fala ou escreve. Desse modo, a importância da obra de arte moderna ocidental está na sua acepção subjetiva, isto é, o valor da obra de arte se desloca constante e crescentemente das qualidades intrínsecas da obra em si para a força significativa da subjetividade de seu criador.

Com base nestas constatações, Calligaris (p. 04), entende quem o escrito autobiográfico (possivelmente, o pesquisador esteja neste caso incluindo no 
autobiográfico as memórias e outros gêneros de natureza confessional) e o diário sejam modalidades de textos priorizados. Escrever sobre si mesmo tornou-se uma necessidade de natureza cultural do mundo atual: a verdade, convictamente, instalada no sujeito aparece vinculada à sua sinceridade. A autobiografia é analisada enquanto uma variedade de formas textuais e subordina a demanda crescente das "escritas do eu" aos avanços da cultura individual ocidental:

Ora se para o sujeito moderno falar de si responde à necessidade cultural imperiosa de reconstruir o mundo e a si mesmo no silêncio deixado pelo ocaso da sociedade tradicional, a série das fórmulas de seus atos autobiográficos deve nos informar de maneira privilegiada sobre seu devir, sobre os caminhos pelos quais ele se constituiu e, quem sabe, sobre o seu futuro. Nesse sentido, uma história da subjetividade moderna é impensável sem 0 auxílio dos atos autobiográficos. (CALLIGARIS, p. 9)

\subsection{Memória e Ficção}

Ao nascer o texto do caos humano, ele traz em seu bojo imposições estéticas que engendram equívocos ou acertos. $A$ memória e a invenção têm uma fonte comum, são indissolúveis. O equilíbrio provém do saber narrativo, de um manancial que propicia o advento da obra de arte.

Nélida Piñon

Para se atingir o sentimento de verdade que a narrativa do "eu" possa provocar no leitor é fundamental que se utilize do imaginário na sua construção, no entanto é o ficcional que a torna verossímil. Assim contar a própria existência é semelhante ao ato de inventar uma vida. Ao falar do "eu", o sujeito o reinventa; razão pela qual o ato autobiográfico "é constitutivo do sujeito e de seu conteúdo" (CALLIGARIS, 1997, p. 10). Ficcionalizar a própria vida é o jeito ocidental moderno de orientá-la e reorientá-la, sendo que a ação autobiográfica é capaz de modificar diretamente o percurso de vida do sujeito; razão pela qual diversas linhas da psicologia utilizam-na como atividade terapêutica. De acordo com a perspectiva apresentada, o ato de contar sua própria existência constitui como uma espécie de 
benéfico para o sujeito que o faz, pelo fato de ser uma atitude condizente com subjetividade entranhada na cultura contemporânea.

A reflexão referente à subjetividade presente na obra literária de caráter intimista, ou memorialista, nos leva a um entendimento de como se dá nesse tipo de texto a relação entre memória e ficção. Considerando o sujeito como um ser inacabado, sempre que se retoma o ponto de partida, para relatar suas lembranças, o "eu" passa por um processo de transformação e reorganização de sua existência. Por isso, sempre que se volta ao ponto de partida do "eu", às suas lembranças do passado, buscando a construção de uma narrativa, tem-se como resultado uma pessoa diferente, pois esta se revela num constante modificar-se conforme as diversas situações e condições experimentadas. Assim, não é possível voltar-se "ao ponto de partida propriamente, sobretudo porque nos tornamos diferentes: a pessoa que regressa não é a mesma que parte" (MAGNO, 2005, p. 4). O poeta ao visitar sua terra natal, através de sua memória, está manifestando um desejo de totalidade, perdida com o transcorrer do tempo e dos diversos eventos ocorridos.

Há uma significativa idéia de proximidade de sentido entre "rememorar" e "inventar" entranhada no pensamento grego em termos do mito e da filosofia, especialmente a de Aristóteles (1993, 449b-53b) para quem a memória e a imaginação vêm da mesma parte da alma. Nesse sentido Adélia Meneses, em seu texto "Memória e Ficção II (Memória: Matéria de mimese)", assinala duas questões relevante a partir da filosofia aristotélica: a ligação da memória com a imaginação e a da imaginação com o desejo (1995, 147).

A referida autora retoma ainda para tratar desses dois pontos dos estudos de Freud, que vão apontar para uma certa desconfiança em relação ao papel desempenhado pela memória, que, juntamente com a imaginação, deixa-se conduzir pelo desejo. Ao contar sobre si, o sujeito o faz de forma a construir uma imagem de si de acordo com seus desejos e seus interesses do presente, os quais numa relação dialógica são afetados pelo olhar do outro.

Assim, pode-se entender que a ligação estabelecida entre memória e imaginário é presidida pelo desejo e está especialmente acoplada à questão do esquecimento. Sabe-se que há uma ambigüidade de sentido no verbo "esquecer-se" no grego, bastante significativa para Meneses, pois a expressão "eu me esqueço" também pode significar "eu me escondo". Observa-se que o esquecimento serve também aos "propósitos da repressão" (Idem, p. 15), em que, muitas vezes, não é 
de interesse daquele que está à frente de determinada instância de poder, que seus subordinados rememorem certos fatos ou acontecimentos que possam despertá-los a perceber aspectos do sistema político, social e econômico que deveriam lhes ser ocultados.

Numa de suas entrevistas, no Programa Roda Viva, de 17 de novembro de 1977, em São Paulo, ao ser questionado sobre a natureza do texto memorialista, Saramago pondera que a memória pode ser falsa: "O que existe são memórias de memórias, vestígios de outras memórias (...)" Ou seja, o distanciamento entre o tempo do acontecimento e o tempo em que a lembrança é retomada abre espaço para a entrada do ficcional. Cabe ao imaginário preencher as lacunas, dar clareza e unidade aos acontecimentos narrados.

Como a palavra está intimamente ligada à memória, é graças às duas que o passado pode se manifestar no presente através do sujeito. De acordo com Alfredo Bosi, o sujeito só se lembra daquilo que não vivenciou através das narrativas que lhes são contadas: "Eu só lembro do que não vi porque me contaram" (BOSI, 1992, p. 28). Para vivenciar e visualizar o passado, reconstruído através da lembrança de alguém que a conta, o sujeito precisa lançar mão da sua habilidade para criar e imaginar. O passado, interpretado pelo narrador testemunha, é novamente imaginado e reelaborado pelo ouvinte que também pode ser um narrador em potencial.

Ao serem atualizadas pelo sujeito que conta ou ouve, as lembranças revelam um passado revestido por diversas faces correspondentes aos diferentes contextos e perspectivas do presente da sua narração ou de sua leitura. Há, então, no ato de rememorar uma questão bastante relevante que é o "convívio dos tempos". Esse convívio entre os vários tempos constitui um dos elementos característicos da pós-modernidade que é "a coabitação de estilos de vida e pensamentos distintos" (Idem, p. 30), desenvolvidos não só em relação aos múltiplos espaços vivenciados pelo homem (através do imaginário ou mesmo da sua experiência), mas também em relação aos vários estilos de vidas, provenientes das mais diferentes épocas.

A ficção está não na experiência bruta, mas no processo de mimese pelo qual passa o fato abordado pela literatura, isto é, "na transposição para o papel e sua necessária transformação, quando entram nos recursos estilísticos, a metáfora, a metonímia, o símbolo a alegoria; quando atuam os processos de elaboração 
poética de condensação e deslocamento..." (Meneses, p. 159-60). Nesse sentido, Olgária Matos afirma que "a imensa força das narrativas provém de uma intensidade imaginativa que imita a liberdade divina, pois é a faculdade de criação (que na tradição sempre caracterizou algo de divino)" (MATOS, p. 21).

As construções ficcionais apresentam-se muito mais coesas e lógicas que a existência. É graças aos recursos utilizados pelo escritor na elaboração e construção dos personagens que estas adquirem complexidade e verossimilhança capaz de torná-las mais "verdadeiras" que o que percebemos e interpretamos de uma pessoa.

A reflexão que Antonio Candido realiza em "A personagem do romance", oferece uma contribuição de grande relevância para fundamentar essa relação entre o real e o imaginário, no que se refere aos gêneros de índole intimista. Para o crítico, a interpretação que fazemos da vida altera conforme passa o tempo, modifica as condições de conduta e a situação. Na existência cotidiana muito pouco se sabe sobre os motivos e as causas das ações cometidas pelas pessoas, já no romance, o escritor se ocupa em descortinar e desvendar habilidosamente as causas do modo de ser e agir de determinadas personagens na sua profundidade, considerando que o essencial do ser fictício é criado ou recriado pelo autor.

O conhecimento que se constrói sobre uma pessoa é infinito, inacabado, fragmentado, muitas vezes contraditório; nesse sentido captar a sua totalidade é impossível. Em contrapartida, ao elaborar um personagem o escritor o delineia de forma mais coesa e menos variável, o que constitui a lógica da personagem num todo completo. Daí pode concluir-se que o ficcional é mais lógico e estável que a vida. O que nos vem da ficção já é estabelecido e é mais preciso que o que nos chega da existência.

Para Candido, "o romancista é incapaz de reproduzir a vida" e ao tentar fazê-lo, quanto mais próximo de sua meta estiver, mais fadado ao fracasso ele vai estar. A "necessidade de selecionar afasta dela e leva o romancista a criar um mundo próprio, acima e além da ilusão de fidelidade" (CANDIDO, 2007, p. 67). Observa-se que no mundo fictício os personagens, além de mais nítidos, são mais conscientes e ganham contornos melhor definidos que a pessoa. O ficcional se opõe ao "caos da vida", pois tanto os personagens quanto os demais elementos que constituem a narrativa se entretecem e se organizam conforme leis próprias da obra, definidas internamente. Por já apresentar suas características delimitadas e 
fixas por seu criador, não significa que a personagem não seja profunda ou complexa. $O$ que acontece é que tudo que o personagem vai apresentar já está dado e pré-estabelecido pelo escritor que seleciona, combina os seus caracteres em busca da lógica e coesão do personagem. A complexidade, a multiplicidade, enfim, toda a força de uma grande personagem se atinge graças à agilidade $e$ engenhosidade de seu criador. São os recursos de caracterização utilizados na construção do personagem que vão lhe dar a impressão de vida. E para passar essa sensação de real, é preciso que o personagem, através de um todo coeso e de sua coerência, dê ao leitor a impressão de ser ilimitado, contraditório e infinito. $\mathrm{O}$ ficcional é, então, mais lógico e não mais simples que a existência.

Conforme a abordagem de Candido, o romance moderno esteve sempre em busca desse sentimento de complexidade apresentado pela existência, devendo para isso camuflar a idéia de um esquema fixo e definido no ato de sua criação. Por mais que o personagem, enquanto resultado da seleção e combinação hábeis de seus elementos caracterizadores, seja múltiplo e complexo, seus traços é em número reduzido, se comparados às diversas peculiaridades do ser humano, que estão em constante mudança e variação. Vários escritores procuram dar a seus personagens uma natureza aberta, ilimitada, mas por serem entidades fictícias suas estruturas já estão predefinidas no ato de sua criação, o que leva o romancista a selecionar e arquitetar os elementos estruturais de sua obra, dando-lhe "a ilusão do ilimitado" (p. 60).

O romance moderno caminha em direção a uma "complicação crescente da psicologia dos personagens, dentro da inevitável simplificação técnica imposta pela necessidade de caracterização" (Idem). Trata-se de uma tendência que acompanhou o gênero romanesco desde os seus primórdios, mas que foi aprimorada e acentuada no romance moderno (do século XVIII ao século $X X$ ), em que as personagens são tratadas de duas maneiras: "como seres íntegros e facilmente delimitáveis", balizados e definidos por determinados traços e "como seres complicados, que não se esgotam nos traços característicos, mas têm certos poços profundos, de onde pode jorrar a cada instante o desconhecido e o mistério" (Idem). Conseqüentemente, "a revolução sofrida pelo romance no século XVIII consistiu numa passagem do enredo complicado com personagem simples, para o enredo simples (coerente, uno) com personagem complicada" (Idem, p. 61). Assim, a complexidade da personagem relacionada à "simplificação dos incidentes da 
narrativa e à unidade relativa de ação, marca o romance moderno" (Idem). A obra Ulisses de James Joyce foi, na verdade o exemplo mais significativo desse acontecimento romanesco, o que assinala de certa maneira uma "subversão no gênero" em questão (ldem).

Tendo em vista a presença da memória como um elemento literário preponderante nas narrativas em estudo, faz-se necessário uma reflexão sobre os apontamentos de Candido referentes à construção dos personagens. O crítico tem como pressuposto básico de sua investigação o conceito de personagem como um ser fictício, por isso, então, o personagem não pode se constituir do seu contrário, sua negação que é a cópia do real. Portanto a personagem não pode ser igual a um ser vivo; ela pode, sim, dar a impressão do ser vivo. Se a criação de um personagem tem como norteio fundamental o desejo de fidelidade ao real, terá então que admitir a oscilação "entre dois limites ideais: "ou é uma transposição fiel de modelos, ou é uma invenção totalmente imaginária" (Idem, p. 70). Assim, a criação da personagem romanesca se dará com base nesses dois limites e nas suas variadas combinações. Só se pode opinar a respeito da natureza da personagem, se exprime ou não o modo-de-ser ou mesmo a aparência física de uma pessoa - que pode ser o escritor ou um outro ser humano qualquer - se for explicitada fora do próprio romance, pelo autor ou por alguma espécie de documento. Mas se não há nenhum dado extratexto que forneça diretamente esta informação, os estudos e análises da "tendência geral do escritor", pode, então, contribuir para que o leitor compreenda, pelo menos em parte, a índole do personagem. A construção literária, balizada então por esses dois elementos polares, pode ter como resultado uma infinidade de tipos de personagens que oscilam, ora mais para o real ora mais para o imaginário.

Em síntese, o que ocorre é na realidade um trabalho fecundo de invenção, fruto de combinações diversas entre dos seguintes elementos: memória, observação e imaginação. Combinação esta, que se dá na sua maior profundidade em nível do inconsciente do escritor, pois este "seria incapaz de determinar a proporção exata de cada elemento", considerando que "esse trabalho se passa em boa parte nas esferas do inconsciente e aflora à consciência sob formas que podem iludir" (Idem, p. 75). A natureza da personagem é dada em parte pelas intenções de seu criador e pela concepção de mundo e de homem em que a narrativa foi desenvolvida. 
Percebe-se que Candido não dá tanta relevância a esta questão, muitas vezes tão difícil de ser definida; para ele, o problema da gênese das personagens tem importância apenas para o estudo da caracterização destas que é pouco significativo para a solução dos problemas essenciais da crítica, como "a interpretação e a análise valorativa de cada romance concreto" (Idem, p. 70). Insistir nesta problemática seria então restringir o romance a algo apenas de "comunicação do sentimento de verdade", enquanto que o referido gênero é fruto do ajuste adequado de inúmeros outros elementos entre si.

A essência verdadeira da personagem depende não só da sua relação com a vida, mas especialmente da organização interna do romance, de como este se estrutura, sendo assim, o aspecto chave do problema literário é a coerência interna. O referido crítico trata neste momento da verossimilhança. Na sua acepção, este conceito, apesar de inicialmente tratar da relação de proximidade ou não entre o mundo ficcional e o mundo real, depende necessariamente da organização estética do componentes internos da obra. Por isso é a coerência interna do texto que o torna verossímil.

Toda impressão de veracidade apresentada pelo texto de memória ao leitor é constituída pela sua verossimilhança tanto externa quanto interna, especialmente esta última, garantida pela capacidade do sujeito de urdir e estruturar os acontecimentos narrados, de modo a articular sabiamente os elementos estéticos e líricos do texto, fluentes no próprio ato de lembrar. Verificação esta que pode ser evidenciada em Percursos, através da forma como a narrativa se apresenta, a qual está em consonância com o processo da rememoração, pois as lembranças nos vêm à consciência de modo desordenado como a própria estrutura do texto. São peculiaridades da estrutura interna do texto que expressam tanto o estado de espírito do homem contemporâneo, desintegrado em busca de unidade, quanto as ruínas em que se transforma a alma humana diante do sofrimento causado pelo colonialismo e pela Guerra Colonial em Angola.

O que mais interessa à critica na perspectiva de estudo de uma narrativa não é que ela corresponda ao real, mas sim em questionar como ela foi desenvolvida e construída. Em contrapartida, o real só poderá ser simulado dentro de uma obra se esta for estruturada e organizada com coerência e habilidade. 


\subsection{Narrativa de memórias: um "eu" em busca de unidade e coesão}

Refletir sobre memórias é uma prática que conduz, conseqüentemente, o pesquisador ao entendimento como se processa a constituição identitária do indivíduo, que, por sua vez, está intimamente relacionada a construção narrativa. Ao tratar da identidade do sujeito pós-modeno, Stuart Hall (2006, p. 13) alerta para a sua incompletude e instabilidade. O sujeito assume identidades diversas diante das várias situações vivenciadas. Identidades essas, muitas vezes, contraditórias por não constituírem uma unidade que tenha por núcleo um "eu" coeso. Para Hall, "o sujeito e a identidade são apenas dois dos conceitos que, tendo sido solapados em suas formas unitárias e essencialistas, proliferam para além de nossas expectativas, através de formas descentradas, assumindo novas posições discursivas" (2003, p. 104). Assim, a sensação que o sujeito tem de possuir uma identidade única e completa do começo ao fim da vida é na verdade uma ilusão, pelo fato de que "construímos uma cômoda estória sobre nós mesmos ou uma confortadora 'narrativa do eu'". A própria natureza do processo de construção da identidade é provisória, imprevisível e instável. Assim a identidade do sujeito quando definida o faz historicamente e não biologicamente.

Ao contar suas recordações do passado as protagonistas-narradoras de Wanda Ramos e de Tereza Albues o fazem de maneira a enlaçar sua narrativa pessoal à história de seu país. Como a identidade do indivíduo para encontrar nexo e se instituir enquanto uma unidade precisa da tessitura de uma narrativa, a identidade de uma nação também depende da constituição de uma história para se estabelecer.

Para Stuart Hall, (muito em consonância com o papel do discurso na constituição do sujeito em Bakhtin, "uma cultura nacional é um discurso - um modo de construir sentidos que influenciam e organizam tanto nossas ações quanto a concepção que temos de nós mesmos..." - 2006, p. 51). A nação ao constituir sua cultura, produz sentidos que instituem a sua identidade. Os sentidos que definem a identidade nacional aparecem contidos nas narrativas - cuja matéria prima é o passado da nação - e, especialmente, nas imagens dela construída ao longo da história de seu povo. O presente é conectado ao passado através da memória e do imaginário, que tem papel preponderante nessa construção identitária da nação. 
A narrativa da cultura nacional se constitui a partir de inúmeras formas de contar, tais como as narrativas populares e literárias, as tradições, em especial, as tradições inventadas e o mito fundador. É importante ressaltar a narrativa do mito fundador, cujo enredo remonta aos acontecimentos primeiros geradores da nação, que geralmente é constituída em conformidade com a ideologia da classe social representada pelos dirigentes do poder.

A denominação mito fundador, segundo Marilena Chauí, apresentam dois sentidos a serem explorados nesta abordagem. Primeiro é o sentido etimológico que remete à narração pública dos acontecimentos lendários que reportam à origem da nação. Já o segundo é o sentido antropológico, em que a narrativa surge como uma espécie de solução imaginária para as situações de conflito, de tensão e de contradições que por diversas razões não são resolvidas no plano do real. O mito é fundador pelo fato de impor uma conexão íntima com o passado enquanto origem, o qual se apresenta como perene (CHAUÍ, 2006, p. 09). Nesse sentido, é relevante diferenciar fundação de formação: fundação é uma palavra que designa o mito em decorrência do seu sentido que situa-se "além do tempo, fora da história", isto é, num presente ininterrupto, quase perene, que pode tomar múltiplas formas; já o termo formação considera não apenas as determinações econômicas, sociais e políticas como elementos condutores dos acontecimentos históricos, mas também o próprio processo histórico com suas formas de representação que de acordo com a ideologia predominante pode-se ocultar ou dar ênfase a determinados eventos. Chauí pondera que "as ideologias, que necessariamente acompanham o movimento histórico da formação, alimentam-se das representações produzidas pela fundação, atualizando-as para adequá-las à nova quadra histórica. É exatamente por isso que, sob novas roupagens, o mito pode repetir-se indefinidamente" (Idem, p. 10).

O permanente deslocamento imposto pela vida moderna, causado pela predominância dos interesses guiados pelos preceitos do capital sobre as relações de âmbito social e afetivo, não permite ao ser humano enraizar-se num determinado espaço ou comunidades (WEIL, 2001, p. 61). O desenraizamento é, segundo Ecléa Bosi, "uma condição desagregadora da memória: sua causa é o predomínio das relações de dinheiro sobre outros vínculos sociais. Ter um passado, eis outro direito da pessoa que deriva de seu enraizamento" (BOSI, 1994, P. 443). A mobilidade constante em que vivem as pessoas, especialmente, as de baixo poder aquisitivo, impede a "sedimentação do passado, perde-se a crônica da família e do indivíduo 
em seu percurso errante. Eis um dos mais cruéis exercícios da opressão econômica sobre o sujeito: a espoliação das lembranças" (Idem, p. 443).

Se a unidade do sujeito está vinculada a unidades maiores como os grupos sociais, as comunidades, à nação, a impotência do Estado diante da violência interna, juntamente com outros eventos dessa estirpe é um dos principais fatores responsáveis pelo sentimento de desagregação do "eu".

Considerando que o fixar-se como componente ativo e participativo da existência de uma coletividade é condição sine qua non para conservação do tesouro do passado e para os pressentimentos do futuro, o enraizamento, para Weil, é uma necessidade e um direito de todo ser humano. Se o mundo contemporâneo caracteriza-se pela fragmentação e pelo desenraizamento, que constituem a condição desagregadora da memória, a tentativa do narrador de relembrar sua história é um ato de resistência em favor da unidade do ser. Assim, o ato de narrar as experiências do passado num contexto árido quanto à ação da memória, torna-se uma travessia árdua, mas frutífera, em favor da constituição da identidade tanto do indivíduo, quanto do grupo ou sociedade na qual está inserido. Nessa perspectiva, a construção da narrativa assume a função de ajuntar os cacos de um passado marcado pelo deslocamento do protagonista-narrador, que concebe o ato de narrar suas experiências como uma possibilidade de alinhavar sua existência itinerante.

O curso de vida da narradora-personagem de Albues é entrecortado por diversos acontecimentos no período a infância, que quebram o equilíbrio e a expectativa de trajeto traçados pela personagem da narrativa. A protagonista, além de vivenciar as constantes mudanças de residência de sua família por vários lugarejos no interior de Mato Grosso, sofre em sua formação pessoal com a autoridade incerta do pai, considerado um demente. Na fase adulta, a personagem ainda perambula por diversas localidade, não pelas proximidades do lugar onde nascera, mas pelo mundo e, assim, sua vida toda é marcada e pelas inconstâncias. Este sentimento de incompletude acentua-se pela existência fracionada, especialmente na maturidade, por fixar residência em Nova York, uma cidade que se caracteriza pela existência de várias etnias justapostas num universo desconecto, sem unidade, pois as pessoas que ali param são, na maioria, oriundas das mais diversas partes do planeta e vivem sem se agregar num único corpo social. 
A narradora se vê, ao contar sua história, diante da possibilidade de tecer os fios de sua memória balizada pela fragmentação. Já no caso da personagemtestemunha de Wanda Ramos, suas "reminiscências" dão conta da constituição de um corpo narrativo que resgata a unidade de seu ser, cujo passado, além de ser caracterizado pelo seu constante transitar, se define pela instabilidade de sua existência num ambiente constituído pela violência do colonialismo e pela guerra. Outro fator que contribui para o esfacelamento do ser é a quebra das expectativas, em relação à Independência de Angola, apresentadas por aqueles que acreditaram nas transformações sociais, políticas e econômicas de Angola (país colonizado) e de Portugal (país colonizador). 
CAPÍTULO II

\section{MEMORIAS: ENTRE BERROS E PERCURSOS}

[...] o passado e o presente não são
coisas estáveis tornadas
interpenetráveis pela memória que
arruma e desarruma as cartas que vai
embaralhando. O passado não é
ordenado nem imóvel - pode vir em
imagens sucessivas, mas sua
verdadeira força reside na
simultaneidade e na multiplicidade
das visagens que se dispõem, se
desarranjam, combinam-se umas às
outras e logo se repelem, construindo
não um passado mas vários
passados.

(Pedro Nava)

\subsection{Apresentando Wanda Ramos}

Wanda Ramos, doze anos mais jovem que a escritora mato-grossense Tereza Albues, nasceu em Angola no ano de 1948 e faleceu em Lisboa no ano de 1998. Filha de portugueses, passou sua infância no Dundo, província da Lunda Sul, em Angola, e seu pai era funcionário da Diamang, mesma companhia de trabalho do pai da protagonista portuguesa. Como se observa, há uma semelhança entre o percurso da protagonista da obra em estudo e a trajetória das experiências de vida da escritora. Como se observou no primeiro capítulo, toda essa compatibilidade entre os dados referentes à vida da pessoa real e os dados referentes às ações da personagem, plausível recriação do que fora a autora no período contemplado pela 
narrativa, não seria lícito definir categoricamente Percursos como uma obra pertencente ao gênero da autobiografia, já que se optou, como base teórica desta abordagem, pela conceituação de Phillipe Lejeune (2008, p. 13-7) sobre autobiografia, em que o pesquisador estima, em 1975, que para se definir um texto como autobiográfico, é preciso encontrar em seu interior alguma passagem em que o escritor assuma objetivamente que a narrativa diz respeito às suas experiências pessoais, o que não é o caso da obra em estudo. Com apenas dez anos de idade, assim que foi aprovada no exame de admissão em Malanje, a autora foi para Portugal, onde realizou os estudos. Jovem, licenciou-se em Filologia Germânica pela Faculdade de Letras de Lisboa e tornou-se poetisa, tradutora e ficcionista. Estreou na literatura em 1970, com o livro de poemas Nas coxas do tempo (1970), em edição de autor, o qual foi seguido de outras várias produções literárias ${ }^{13}$.

Wanda Ramos foi uma das gerenciadoras da Associação Portuguesa de Escritores no período de 1982 e 1984; traduziu obras de vários escritores, dentre eles, Jorge Luís Borges, Octavio Paz, Tagore, John le Carré, Michel Tournier e ainda colaborou em diversos jornais portugueses. Recebeu, em 1991, o Prémio Literário Cidade de Almada para romances inéditos pelo romance Litoral (Ara Solis), obra também produzida a partir das experiências pessoais.

Observando a linguagem que constitui os textos e o refino artístico ao lidar com as palavras de Wanda Ramos, entende-se que sua habilidade na produção literária pode ser o resultado de sua formação em Letras, sua proximidade com os grandes escritores e seu desempenho na área da tradução para o português de inúmeros textos de autores expressamente relevantes do mundo intelectual e literário escritos em francês, espanhol, alemão e inglês. A temática do tempo permeia tanto as obras poéticas quanto as narrativas da maioria dos textos da autora. Em As incontáveis vésperas, por exemplo, a idéia do tempo está expressa naquilo que é antecipado, mas que nunca chega a concretizar-se. O romance Percursos, que além de lhe render o prêmio de Ficção da Associação Portuguesa de Escritores, em 1982, e Ihe consagrar como uma das escritoras contemporâneas

${ }^{13}$ É Contudo cantar sempre (1979 - poesia), Percursos - Do Luachimo ao Luena (1981 - romance), As Incontáveis Vésperas (1983 - romance), Intimidade da fala (1983 - prosa poética) Poemas-comsentidos (1986 - poesia), Um homem cabeça de pedra (1988), Crônica de Estuário ao Fundo, (1998 - crônicas), Os Dias Depois (1990 - contos), Litoral (Ara Solis - 1991 - romance). A autora conta também com textos publicados nas antologias Experiência da liberdade (1975), Jovem poesia portuguesa (volume I) e Companheiro vasco (1977). 
portuguesas mais importantes, traz a questão do tempo significativamente elaborada na narrativa pelo cronotopo do rio.

Sua obra Crônicas de estuário ao fundo (1998), ao ser publicada primeiramente numa edição bilíngüe na França (1997), reafirma essa característica da obra de Wanda Ramos, que vai além das fronteiras da língua portuguesa, conduzindo, assim, o seu leitor a entender a complexidade do sujeito da atualidade, fato que ocorre talvez até pelo seu desempenho como tradutora ao lidar com diversos idiomas. O estuário, como sugere o título, é o cronotopo a partir do qual se desenvolve a maior parte do enredo. O estuário por ser o encontro expandido do rio com o mar - justamente na França, país que teve sua cultura e língua espalhadas por várias nações -, onde aportam os navios, lugar de partida e de chegada das embarcações e, assim, se constitui enquanto uma metáfora do encontro das pessoas e as misturas diversas de mundos múltiplos.

\subsection{Tereza Albues e sua obra}

Mato Grosso é uma força tão imensa, com a qual me cerco em minha casa. Tenho quadros de São Sebastião, de Humberto Espíndola, uns adornos indígenas e muitas pedras cangas que levo daqui. Todo este material me traz tanta felicidade, tanta força, para criar. Coloco minha mesa no meio disso tudo, envolvida por este mundo que eu transportei daqui para lá, para me dar aquele apoio a tudo que eu já tenho dentro de mim. Mato Grosso está muito vivo em Nova York.

(Tereza Albues)

Tereza Albues nasceu em Várzea Grande, em 24 de agosto 1936, e passou grande parte da infância em Nossa Senhora do Livramento, cidade vizinha 
da capital mato-grossense. Há informações de que aos sete anos de idade já dava seus primeiros passos rumo à carreira de escritora, pois já produzira, naquele tempo, alguns "versos que foram jogados fora, sem deixar nenhuma lembrança daquela época inesquecível" (BARBOSA,1995). Morou nos Estados Unidos de 1980 até 5 de outubro de 2005, data de seu falecimento, quando foi derrotada por um câncer. Casou-se com Rob Eisenstat, um arquiteto americano que sobreviveu à tragédia da queda das Torres Gêmeas.

Mesmo vivendo seus últimos 25 anos nos Estados Unidos e se adaptando ao modo de vida nova-iorquino, a escritora produziu suas obras todas em português e publicou-as em editoras brasileiras. Além do mais, ela manteve forte ligação com a sua língua materna, com a cultura mato-grossense e sustentou, principalmente, a chama da memória e da imaginação bem alimentadas pela sua sensibilidade e simplicidade diante da vida, o suficiente para produzir, a partir de suas lembranças, vários romances, em que suas principais ações têm como espaço o Mato Grosso da infância e da adolescência da autora.

Concluiu três cursos superiores, Letras, Direito e Jornalismo pela Universidade Federal do Rio de Janeiro. Na década de 70, exerceu a profissão de professora de latim e português. Em 1982, Albues escreve o roteiro curta metragem Curral das Águas, que foi levado ao ar pelas redes de televisão Centro América, emissora da Globo em Mato Grosso, e Bandeirantes, em São Paulo. Conforme observa Nelly Novaes Coelho (2002, p. 615), foi um vídeo que chamou a atenção do público telespectador "pela denúncia da situação dramática vivida por homens do campo que, ludibriados por falsas promessas, são levados para o Pantanal, e ali obrigados a trabalhar em regime de escravidão". Como se observa, a questão da injustiça do trabalho escravo vai reaparecer com força na narrativa de $O$ berro.

Tereza passa a residir em Nova York a partir de 1983. Em 1985, escreve o romance Pedra canga, publicado dois anos depois, em 1987, no Rio de Janeiro, por meio do qual Albues estréia como romancista. É traduzido para o inglês em 2001 e publicado em território americano, onde ganha atenção especial da crítica literária, inclusive, um dos críticos de jornal americano aproximou alguns elementos literários de Pedra Canga da obra Macondo, de Gabriel Garcia Marques. Há, nesse romance de Tereza, ainda questões de especial particularidade, como "a terra-de-origem, a 'casa como morada do ser', a ausência de fronteiras entre vida e morte, o atemporal, a atmosfera de magia [...]" (COELHO, 2002, p.615), que vão ecoar, em suas obras 
subseqüentes, esta primeira produção romanesca, como: Chapada da palma roxa (1991), A travessia dos sempre-vivos (1993), O berro do Cordeiro em Nova York (1995), A dança do jaguar (2000) e O buquê de línguas (2008).

Como observa Hilda Magalhães (2001), a trama das obras de Tereza Albues é edificada a partir da presença de elementos como o sobrenatural, ao qual está ligado o ecumenismo, formado pela presença de personagens pertencentes a diversas religiões (catolicismo, o espiritismo e o umbandismo) e a partir dos seguintes dualismos: o bem e o mal (maniqueísmo), a cultura urbana e a cultura rural.

O romance $A$ Travessia dos sempre vivos, publicado em 1993 e lançado na VI Bienal Internacional do Livro, foi a terceira obra da autora mato-grossense. Albues explica sobre esse romance que apesar de contar uma história a partir de fatos reais, não é um texto autobiográfico, "é uma história inspirada em dados reais, mas mesclada com a ficção" (ALBUES, 1993). Oscilando entre a ficcional e o real, a narrativa se constrói a partir de três perspectivas, correspondentes aos seguintes personagens: o João Padre, Teodora, negra que lhe arrebatara o coração, cujo nome na realidade era Maria Joana e Taisha, sua bisneta. Afirma Tereza Albues: "[...] foram histórias transmitidas pelos seus familiares sobre um homem maravilhoso: poliglota, carismático, um sábio. Minha maneira de contar sua vida foi escrevendo as histórias que ouvi e que contam ainda hoje. Não encontrei nada escrito que contasse a sua vida" (apud MATOS, 1993). A personagem principal da narrativa João Padre foi construída a partir de referencias da vida de uma pessoa pelo imaginário popular, fonte onde bebe a escritora para construir a sua obra.

Na busca incansável de si mesma, Tereza Albues dá um salto relevante na sua produção literária ao escrever, em 1995, O berro do Cordeiro em Nova York, que, para Geraldo Thomas (2005), seu grande amigo, "não se pode chamá-lo de romance, apesar de sê-lo: trata-se de uma autobiografia em disfarce". Nessa narrativa, centrada principalmente na infância da narradora-personagem, o espírito de João Padre (protagonista de $A$ travessia dos sempre vivos) é evocado no romance em estudo como protetor da personagem Venâncio, seu neto e pai da protagonista de $O$ berro, na sua fuga para libertar a si e a sua família das implacáveis injustiças sofridas diante do trabalho escravo a que foram submetidos numa fazenda do Pantanal. Essa passagem constitui o principal gancho entre o 
enredo de $O$ berro e de $A$ travessia dos sempre vivos, considerando que essas duas obras têm muitos traços que as aproximam do gênero da memória.

No romance $A$ dança do Jaguar, publicado em 2000, apesar de o título remeter a um animal próprio das terras do continente sul americano, os acontecimentos narrados se dão na cidade São Francisco. Os mistérios, os enigmas e o mítico que perpassam as suas obras anteriores são transplantados da pacata realidade mato-grossense para a "fervilhante" realidade norte-americana. A narrativa mescla o real e o imaginário, desenvolve-se a partir do espaço da casa ("solar Maltesa"), que funciona como elemento nuclear para o desenrolar das ações. Fazendo o uso do discurso em primeira pessoa, a protagonista conta a história de uma jovem pintora que aluga uma casa em São Francisco para transformá-la em moradia e estúdio. Casa esta que a personagem vai dividir com outro personagem enigmático. Para Nely Novaes Coelho (2002, p. 617), nessa narrativa, "o berro é substituído pela voz tranqüila e envolvente de uma jovem pintora”.

Em 2008, foi lançada uma coletânea de contos da autora, Buquê de línguas. O conto que dá título à obra, Buquê de Línguas, concluído em 1999, é o mesmo que deu à Tereza Albues a menção honrosa no concurso de contos Guimarães Rosa, promovido pela Radio France International, em Paris. A obra de Albues, especialmente essa coletânea, ao mesmo tempo em que traz questões aparentemente particulares, como a experiência cotidiana, o regional e o local, revela algo de universal, amplo e grandioso, uma espécie de conexão com o que caracteriza o mundo global da atualidade, em que se convive com diferentes valores culturais através dos meios de comunicação e da presença das pessoas que, graças à facilidade propiciada pelos avanços dos meios de transporte, podem estar pessoalmente em diversas partes do mundo durante um curto espaço de tempo. É essa fusão de mundos diferentes que está expressa na formação da própria Tereza Albues. Quando menina, vivenciou a simplicidade e a dureza da realidade mato-grossense, caracterizada pela presença da natureza ainda pouco modificada pelas mãos do homem, pela vida simples e aquietada das cidades pequenas e, na vida adulta, em sua maturidade, presencia o fervor da vida urbana nova-iorquina.

Há mais de uma década, em 1995, sua visão manifestava-se positivamente a respeito da mistura de diversas culturas e povos, de todas as religiões, credos e valores morais, como se observa nesta passagem, publicada no 
jornal Folha do Estado: "Você anda nas ruas e vê as cores de todos os países. Nova York é como se fosse um grande caldeirão que está sempre em efervescência. Esta energia é uma coisa fantástica para a criação de meu trabalho. E tem espaço para todas estas tendências" (Folha do Estado,1995, F3). O próprio título do livro e do conto - Buquê de línguas - representa metaforicamente a multiplicidade, a leveza e a vivacidade presentes em toda obra da autora, a qual, podemos afirmar, que é inspirada na intensidade com que viveu suas experiências no quotidiano. Lucinda Persona, no texto de apresentação da referida coletânea de contos, afirma: "Tereza Albues: a apaixonada Cosmovisão" alerta para a inquietude e a "ressonância nômade" impregnadas nas narrativas albuesianas (PERSONA, 2008, p.10).

\subsection{Apresentando Percursos}

Ao atentar para a estrutura da narrativa de Percursos, constata-se que a mesma contém quarenta e seis "capítulos-fragmentos" denominados de "reminiscência" e ordenados numericamente - "Primeira reminiscência", "Segunda reminiscência", "Terceira reminiscência" e assim sucessivamente -, os quais estão dispostos no corpo do texto em ordem crescente, mas com algumas interrupções nessa linearidade por duas posposições e quatro antecipações. Além de sugerir a alinearidade do funcionamento da memória, essas quebras no seguimento das "reminiscências" têm em vista alguma função argumentativa e mesmo estética, como aproximar capítulos que versam sobre determinado assunto ligado a eventos de épocas distintas. Por exemplo, o rio que é uma questão de acentuada relevância na obra, tratado na "Trigésima terceira reminiscência" e na "Décima quinta reminiscência" pode ser o motivo da justaposição desses dois capítulos (p. 66-68). Em sentido geral da estrutura da narrativa, a sequência das "reminiscências" é dividida em fases temporais distintas, mas também por assunto, em conformidade com o processo de rememoração; essas fases são divisadas e encerradas por 
outros quatro capítulos-fragmentos, de teor essencialmente metanarrativo ${ }^{14}$ e de títulos muito sugestivos em termos de significado: "Limbo", "Hiato", "Interlúdio" e "Proscênio".

"Reminiscência" (que no caso dessa obra é também metanarrativa) é um vocábulo que alude à natureza memorialista do discurso e, consequentemente, anuncia um considerável distanciamento entre o tempo da narração e o tempo dos acontecimentos narrados. Um dos importantes significados do conceito de "reminiscência" traz a ideia de fragmentos, de estilhaços do passado guardados na memória, capturados pelo sujeito no presente, sendo o esquecimento um dos principais responsáveis pela falta de completude daquilo que é recordado. Com base na disposição dos capítulos de Percursos, a quebrar o habitual, Carina Faustino Santos pondera que Wanda Ramos "baralha a cronologia (que não o tempo), para significar a rica complexidade do humano viver e imaginar e produzir" (sic) (2003, p.78). Elza Mine, ao abordar as antecipações e posposições de "reminiscências", conclui que o curso da narrativa é alinear e que essa disposição numérica desordenada pode sugerir "o funcionamento peculiar da rememoração, que opera por concomitâncias" (1997, p. 131). Sabe-se que os fatos e acontecimentos, na realidade, ocorrem numa ordem cronológica, mas depois de assimilados pelo sujeito e guardados na sua memória embaralham-se, pois, ao serem rememorados, aparecem de modo caótico e, assim, os acontecimentos mais recentes podem vir misturados ou após os fatos remotos. Aquilo que é rememorado ganha linearidade ou outra forma de organização do discurso graças à habilidade do narrador de lidar com a linguagem e, neste caso específico, com a linguagem escrita, o que implica em lembrar, imaginar, recriar as percepções que tivera no passado, concretizando-as em texto. Se, de um lado, esses capítulos apresentam a nuanças de testemunho, os capítulos que os separam em blocos constituem-se rápidas reflexões metadiegética. As dezoito primeiras "reminiscências" alusivas à infância da protagonista constituem a parte da obra que dá suporte à narrativa como um todo, levando em consideração não só pelo fato de tratar, predominantemente, das experiências da infância da protagonista, que servem de base fundamental na formação e na construção da personagem, mas também pela ponderação sobre o

\footnotetext{
${ }^{14} \mathrm{O}$ conceito de "metanarrativa' designa toda narrativa cujo discurso volta para si próprio, isto é, uma narrativa que trata de sua própria construção, podendo ser definida também como "metadiegese" (na visão dos estruturalistas franceses).
} 
fazer narrativo realizada no capítulo "Limbo", que encerra o primeiro bloco das "reminiscências" com a abordagem metalingüística, que compara a escrita da obra à construção de um edifício, sendo esta primeira fase da narrativa figuradamente o seu alicerce: "Tantos dias para os fundamentos deste edifício, que há de aguardarse pacientemente ver-se crescer e subir além do solo e muito mais há de esperar por algum rendilhado de cornija [...]" (p.43).

A ideia de transição permeia esse capítulo em vários aspectos, dentre eles, pela sua localização na narrativa, pois o bloco de reminiscência posposto vai tratar da adolescência e das férias da protagonista; são designações que se refere a um momento intermediário: o período que compreende a fase da vida entre a infância e a fase adulta da personagem e o momento da narrativa constituído pelo espaço de tempo entre um bloco e outro de reminiscências. "Limbo", conforme os preceitos da tradição cristã, designa o lugar para onde vão as almas que não atendem aos requisitos nem do céu e nem do inferno. Existe também a expressão "colocar no limbo", cujo sentido nos remete ao esquecimento; como observa Elza Miné, "por no limbo" corresponde "a um tempo sobre o qual não se aplica o exercício voluntário da rememoração" (1997, p. 132). Nesse sentido, a crítica refere-se à memória involuntária em que recordações de determinados acontecimentos saltam do inconsciente para o consciente do sujeito, independentemente da vontade deste de querer ou não se lembrar do ocorrido.

É instigante para o foco desta análise a ideia de passagem que pode estar anunciada neste título: "o limbo simbolizaria apenas, na acepção corrente, a antesala do paraíso ou os preparativos de uma nova era da civilização" (CHEVALIER; GREERBRANT, 1994, p. 548). Levando em consideração que o primeiro bloco de "reminiscência" refere-se, em sua predominância, à infância da protagonista e, especialmente, ao momento do colonialismo português que precede a Guerra Colonial, esta parte da narrativa trata, tanto do ponto de vista estrutural quanto semântico, de uma fase de preparação para a guerra, por isso, transitória, que resultará em novos rumos político, social e econômico, que remete ao princípio da construção de um novo país. Nesse sentido, a leitura de Percursos efetuada por Ângela Beatriz Faria - em seu artigo "Percursos e subjetividades femininas em cena, no período da Guerra Colonial" (2009) - aponta para a presença de "olhares préinaugurais" e "cognoscentes", que revelam "sujeitos em processo de 
reconfiguração identitária" (p.11) nesse período, em que o Império Português ruía e se anunciava uma nova ordem cultural, social e política.

É ainda pertinente atentar, no que diz respeito a essa ideia de passagem e transição da infâcia para a vida adulta, que "limbo" designa os preparativos de construção de uma nova forma da protagonista de ser e de estar no mundo, já que as reminiscências que versam sobre esse momento, centram na infância e na préadolescência da personagem, passadas em Angola. O período de tempo e de espaço onde se dão as ações da personagem referente a esse bloco da narrativa constitui o cronotopo ainda do colonialismo português que antecede à Guerra Colonial. A memória e a história se entrelaçam na construção da narrativa. Há aí uma relação entre os fatos de ordem particular e individual, que são aqueles ligados à vida da personagem de Wanda Ramos e os fatos relacionados a um evento de ordem universal, que, nesse caso, é diretamente a Guerra Colonial e o fim do Império Português.

Todos esses capítulos divisores das fases da rememoração são nomeados por títulos, cujos significados sugerem a ideia de transição ou de um interstício divisor. "Hiato", além de ser o encontro de dois sons vocálicos em sílabas separadas, pode estar relacionado com fenda, lacuna, intervalo, férias; é, assim, uma espécie de entre-lugar, fronteira. "Interlúdio" é derivado do latim interludere, nome que se dava a um breve episódio ou a uma parte lúdica, que é apresentado entremeio à sequência normal dos atos de uma peça teatral. Inicialmente, indicava uma peça rápida e autônoma de natureza lúdica ou burlesca e no transcorrer da história foi expandindo sua base de significação. Como um intermédio ou um entreato, "Interlúdio" pode ser um "trecho de música instrumental que se intercala entre as várias partes de uma longa composição, do tipo ópera, missa ou cantata" (FARIA, 2009, p.16). Depois do "Interlúdio", surgem então "Proscênio", vocábulo que vem do grego proskênio, que diz respeito ao que vem antes da cena. É o título do capítulo que encerra o último bloco de "reminiscências". Dessa maneira, a narrativa também mantém uma relação intertextual com a arte teatral. Nesse caso, representa alegoricamente o espaço intermediário entre a narrativa e o público leitor. "Proscênio" é, então, o termo que nomeia a frente do palco, ou seja, o espaço intermediário entre o cenário (fictício) e a realidade (constituída pela platéia); é figuradamente o entremeio entre o interior da narrativa e o mundo exterior, com o qual a obra busca estabelecer uma relação de verossimilhança. Outra leitura a ser 
efetuada é que esse último capítulo simula metalinguisticamente a transformação das lembranças em uma peça de teatro a ser representada. Nele há uma passagem que descreve uma sequência de fotos, como num cartaz de propaganda, que revelaria ao público uma sinopse de toda a história da heroína:

[...] tão altos dias de cassamba afinal únicos porventura frutuosos, de para com meia-dúzia de fotos atestando ter passado de sonho, ela com um cachorro, ela no rio, ela no jeep com os miúdos do quimbo, batuque de domingo com muquixe, retrato de grupo circuncisado [...] (p. 95).

A idéia de "flash", confirmada significativamente pelas fotos, reforçam também a estrutura fragmentada da narrativa, mas que, mesmo assim, trazem uma sequência acompanhando a linha do tempo. Assim, faz-se presente aqui mais uma intertextualidade entre a narrativa e a arte visual, a fotografia. Em "Proscênio", depara-se ainda com uma relação dialógica com a poesia - a literatura angolana por meio da epígrafe constituída por uma passagem de Nos, os do Makulusu, de Luandinio Vieira, que versa sobre o desejo dos seus personagens, diante do cenário da guerra, de se verem livre desta: "Olha, Mais-Velho: não a odeias mais do que eu. E só há uma maneira de a acabar, esta guerra que não queres e eu não quero: é fazer-lhe depressa, até no fim, gastá-la toda, matar-lhe" (Ibidem). E, logo no início do capítulo, a transcrição sucinta de um trecho de poema de linguagem metalingüística que estabelece uma relação intertextual da narrativa com a poesia: "longe a leste/ arrasa-se diariamente um poema/ de vida de vertigens tecida/ no paradoxo. Conluio de mitos/ e história o exercício insensato e cru/ das vossas mãos de farpas..." (lbidem).

Distintos dos capítulos que narram as experiências de vida da protagonista ("Reminiscências"), esses quatro capítulos ("Limbo, "Hiato", "Interlúdio" e "Proscênio"), significativos quanto à estrutura e o teor, chamam a atenção do leitor para a ideia de transição, de indefinição e de diálogo da narrativa com a poesia e da literatura com outras formas de artes, como as artes cênicas, as visuais e a arquitetura, que estão contempladas na abordagem metalingüística de Percursos. $\bigcirc$ conteúdo desses capítulos, reforçado pelo significado expresso por seus títulos, remete o leitor constantemente a um lugar de passagem, a uma espécie de fronteira, uma referência ao híbrido. Referem-se, então, às fronteiras entre a memória e a ficção, a memória e a escrita, entre a literatura e as outras artes, entre 
a arte e a realidade. O último capítulo, de nome "Proscênio", por definir o espaço entre a arte e o público, representa simbolicamente a quebra da possível ilusão de realidade que por ventura a narrativa no seu todo tenha criado. Por estar no fim da narrativa, este capítulo pode demarcar o transitar, ou seja, o entremeio entre a arte e a realidade.

O perfil emocional da heroína de Percursos é caracterizado pela solidão, pelo isolamento, pelo tédio, pela falta de liberdade e pela ausência de respostas às suas dúvidas, principalmente no período de sua infância. Suas vontades, suas perguntas e dúvidas nunca eram levadas em consideração na vida familiar, principalmente, pela figura paterna. Era criada e educada para ser uma figura exemplar aos padrões portugueses; seu comportamento deveria, como lhe exigia o pai, estar à altura de ser exposto como amostra: "acarretava às costas para onde quer que fosse a recomendação, ser sempre a melhor, a mais sossegada, a suprema, haviam todos de falar da filha dos Fulanos, exemplaríssima..." (p. 25). Sempre fora proibida pelos seus pais de se divertir como as outras crianças de sua idade, mesmo as suas conterrâneas, pois estas pertenciam, na opinião deles, às famílias de nível social e econômico inferior ao de seu grupo e podendo, assim, influenciá-la negativamente. A menina passa, então, sua infância no espaço e no ambiente privado, restrito da casa ocupada pela família, em companhia da mãe e dos criados responsáveis pelo serviço doméstico. Ela sofria por ser impedida de efetuar qualquer movimento que desse vazão a seu espírito ousado e aventureiro de criança. Aos nove anos, parte para Lisboa e lá, na companhia dos avós, deu prosseguimento a seus estudos que deveriam, na opinião de seus progenitores, ocorrer distante do convívio com os hábitos "abomináveis" dos nativos em Angola. Apesar da estrutura fragmentada apresentada pela narrativa no que diz respeito ao cotidiano de sua vida de estudante em Portugal, percebe-se que a natureza peculiar da formação familiar da protagonista, estabelecida na colônia, continua na metrópole, só que ainda de maneira mais determinada: "[...] ela para ali como um cãozinho de circo a dar espetáculo, como mais tarde o avô havia de querer dela e já fazia com a irmã..." (p. 37).

Existem, então, diversas lacunas na linearidade temporal do percurso narrativo quanto ao relato das experiências vivenciadas pela protagonista em Lisboa. A voz do narrador, norteada pelo rememorar da personagem, é silenciada no que diz respeito aos anos de sua formação acadêmica em Portugal. O tempo dos 
acontecimentos narrados aparece reduzido ao momento de sua infância em Angola e a sua rápida chegada em Lisboa, junto com os pais, entre nove ou dez anos, que envolve o encontro com os avós a recepcioná-los e só vai ser retomado quando a protagonista, com seus dezesseis anos, volta a Angola para passar suas férias dos estudos realizados em Lisboa e depois como adulta, para fazer companhia ao esposo na Guerra Colonial. Sempre que a protagonista esteve em Portugal, no período contemplado pela narrativa, para prosseguir os estudos lá realizados ou por qualquer outro motivo, o percurso narrativo é silenciado; por isso, quase nenhum evento ligado às ações do romance diretamente limitadas ao cronotopo da Metrópole é tratado no texto. Entre os momentos de férias passadas em Angola pela personagem e o momento em que ela aparece já casada na narrativa há uma lacuna significativa no percurso de experiências evidenciado no texto, a qual equivale possivelmente à sua vida em Portugal. O narrador só volta a relatar os fatos ligados à vida da personagem quando esta já está casada, em companhia do marido, alferes no período da Guerra.

Questões como namoro, sexualidade e amizade com outras meninas, concernentes à fase da adolescência da protagonista, apresentam-se situadas no tempo dos acontecimentos correspondentes às férias dos estudos em Lisboa passadas em Angola: "[...] anos decorridos crescida já, adolescente que o corpo ia soltando no afeto, nos gestos de entre-dois e cavaqueiras com macho [...]" (p. 45). De acordo com os preceitos de nossa cultura ocidental, em que a adolescência é um momento decisivo para o desenvolvimento do ser humano, a narrativa apresenta atenção especial para essa fase da vida de índole transitória e interstícia, que é a adolescência da protagonista, a combinar com o sentido de entremeio do título "Limbo" do capítulo metalinguístico, marco divisório entre a parte da narrativa centrada na infância e a que trata da adolescência da personagem, momento este que coincide com os primeiros anos da Guerra Colonial em Angola. Ajusta com essa passagem também a mudança de cronotopo, assinalada no texto pela simbólica transferência da personagem do rio Luachimo, rio da infância, para o rio Luena, referido no princípio da "Vigésima reminiscência", primeiro capítulo do segundo bloco de "reminiscências". Consta, ainda neste momento da narrativa, a entrada da protagonista para a universidade: 
[...] havia esse rio luena de se lhe abrir como estava inscrito na lenda indígena, urdido na sombra o acaso de ir encontrar os pais em Angola [...] às portas dessa aventura mitificada que é entrar na universidade. [...] Eclodira há cerca de três anos a guerra colonial e dos muitos saídos das crises estudantis de 62..." (p. 45-46).

Vê-se, então, que após focalizar a adolescência (o segundo nascimento) da personagem, a narrativa centra-se na sua fase adulta. A vida de casada da protagonista com uma pessoa a prestar o serviço militar no "ultramar" Ihe faz mergulhar longamente num mar de solidão, tédio e isolamento. Muitas mulheres de sua época tiveram em comum com ela os mesmos dissabores de "esposas dos alferes, sitiadas nos aquartelamentos ou messes, no período da guerra colonial" (FARIA, 2009, p. 11). Algumas dessas mulheres se fazem representar na literatura portuguesa como personagens principais de suas próprias obras. O período de tempo da narrativa focalizada corresponde mais ou menos ao final da década de quarenta, décadas de cinquenta, sessenta e início dos anos setenta.

Wanda Ramos, lançando mão de sua capacidade de rememorar, imaginar e interpretar a realidade com maestria, cria um percurso narrativo em consonância com as suas experiências de vida, inseridas no contexto do final do colonialismo português e da Guerra Colonial Angolana. A escritora usa, para mediar a voz da personagem principal, um narrador em terceira pessoa. Apesar de o texto dar a entender que se trata de uma autobiografia, não evidencia nenhum traço distintivo que se possa confirmar a presença de alguma analogia referencial entre o "eu" da protagonista e o "eu" da pessoa de Wanda Ramos.

$\mathrm{O}$ isolamento experimentado pela personagem no tempo de menina perdura em sua vida depois de adulta, mas demarcado pela situação da Guerra. Verifica-se que o distanciamento entre o tempo da narração e o tempo da narrativa vai permitir que o olhar da heroína que permeia a narrativa seja definido pela riqueza de experiências de vida da autora, especialmente pela sua formação acadêmica em Letras, pelas experiências adquiridas como tradutora e, em contrapartida, com os descontentamentos e as frustrações diante dos resultados obtidos por tantos anos de luta.

A ideia de fluxo, de movimento contínuo e de itinerância presente no sentido semântico e metafórico do título Percursos remete o leitor à natureza memorialística do texto, balizada pela figura significativa dos dois importantes rios da geografia angolana, Luachimo e Luena, presentes de forma relevante no enredo e 
no título da obra (Do Luachimo ao Luena). O termo percursos define, então, a "gênese" da obra e sua natureza cosmogônica, relacionando-a à memória e à ficção, no sentido mais complexo e profundo da existência humana, por se tratar do percurso da construção da narrativa efetuado pelo narrador, do percurso da escritora a lembrar e a inventar o que escreve, dando corpo a sua obra por meio da linguagem e, por último, o percurso do leitor que se identifica com a personagem a rememorar sua existência e sente-se também tentado a fazê-lo. O fluxo das águas de um rio em constante correnteza pode ser a metáfora do próprio fluxo narrativo, cuja matéria-prima são as recordações das experiências do sujeito. O longo, difícil e importante trabalho de rememorar e narrar constitui-se como a realização de um percurso. O rio Luachimo designa o espaço das experiências da infância da protagonista contempladas na narrativa e o rio Luena, o espaço das experiências da adolescência e da vida adulta. Essa dualidade, demarcada pela manifestação de dois espaços e dois momentos definidores das ações da personagem principal, prossegue ainda sob outra perspectiva, que é o espaço privado da casa grande da infância da protagonista e o espaço público predominante onde se dão os acontecimentos referentes à fase adulta da personagem. Existe também um outro par de opostos na definição dos espaços da narrativa, que são a Angola da infância da heroína - definida pela presença de elementos da natureza, como as chuvas, o cheiro da terra, pelo imaginário infantil, coincidente com o imaginário coletivo proveniente das etnias locais - e Portugal, conhecido à distância por meio dos brinquedos, dos tecidos e de outros objetos recebidos de lá através do conteúdo dos livros escolares, em que a personagem aprendia o nome dos rios e das cidades. A imagem de Portugal apresentada no conteúdo escolar estudado pela personagem se contrapunha à imagem construída na perspectiva dos angolanos, com quem ela aprendeu a chamar a metrópole de puto, sendo que esta também divergia da imagem que a mãe lhe passava em momentos de melancolia, considerando que a mãe revelava, nessas horas nostálgicas, uma visão positiva de seu passado junto da família vivido em Portugal. Na adolescência, ocorre uma transformação na perspectiva da protagonista quanto aos espaços conhecidos à distância ou habitados por ela: existe o Portugal das suas experiências cotidianas do período escolar, como se observou, omitidas pela voz do narrador, que forma, distintamente do que the ocorre na infância, outro par de opostos com a Angola, marcada pela hostilidade da guerra que se iniciava no princípio da década de sessenta e lugar 
onde a personagem passava na companhia dos pais algumas de suas férias dos estudos realizado em Lisboa.

\subsection{Percursos e a identidade portuguesa}

No sentido de situar e contextualizar com mais precisão a obra de Wanda Ramos analisada neste trabalho, é importante que se reflita sobre a "ideiametáfora" de Portugal como "País-Cais", considerando que a narrativa traz como personagem principal uma filha de portugueses que além de nascer em terras do "além-mar" (em Angola), vive lá "transitoriamente". Mesmo vivendo distante de Portugal, os pais da personagem - como seus demais conterrâneos que criam suas famílias nas colônias portugueses em África - conduzem a formação de sua filha dentro dos parâmetros estabelecidos pela metrópole. Diante dessa exigência estabelecida pela sociedade portuguesa, a relação ensino-aprendizagem torna-se vaga, inconsistente e desconexa em relação ao quotidiano da criança ou do adolescente que vive muito distante dos modelos sociais portugueses. As experiências do sujeito com a cultura local são negadas em nome de uma "superioridade cultural" do país colonizador, pois mesmo residindo na colônia desde o nascimento, o sujeito é conduzido forçosamente pelo poder colonizador a forjar uma identidade metropolitana por meio da formação escolar, familiar e cultural. $\mathrm{O}$ texto de Wanda Ramos dá ao leitor fortes e significativas pegadas no sentido de evidenciar o tipo de vida que o português levava no "além mar" na condição de deslocado à procura de prosperidade: "Calções brancos impecavelmente, na dificuldade da terra barrenta e da água para lavar trazida aos bidões, capacete, camisa de manga curta e larga tipo safári, como depois foi moda por cá e hoje se vê muito mais no deslocado hábito dos 'desalojados'” (p. 13).

Outra problemática relevante em Percursos a ser abordada se encontra no contexto sociocultural, político e histórico de Portugal e funciona como pano de fundo do percurso narrativo da obra. É a natureza itinerante arraigada na identidade do português que aparece como uma constante ao longo da história e da tradição lusitana, visto que o país esteve sempre voltado para fora de si enquanto Nação. Segundo Isabel Allegro de Magalhães, em Capelas imperfeitas: configurações literárias da identidade portuguesa (2002, p. 349-382), trata-se de uma condição 
experimentada pelo português e entranhada em sua forma de estar no mundo desde a Idade Média e que acompanha a literatura portuguesa desde as origens do Estado português, passando pela expansão marítima dos séculos $\mathrm{XV}, \mathrm{XVII}$ e chegando às fugas em razão das perseguições de índole político-religiosa nos séculos XIX e XX. Como consequência dessas partidas, as viagens de regressos resultaram em um considerável número de obras que tratam de viagens na literatura recente: "as viagens de que se fala são de fato quase todas de nostos ${ }^{15}$, isto é, viagem de retorno ao chão pátrio" (MAGALHÃES, 2002, p. 314). Dentro dessa definição de Portugal, "país como Cais", existem determinadas obras literárias que recriam e ficcionalizam os dois lados daqueles que estão no cais português: os que vão partir, marcados pela dúvida, pelo medo, pela ansiedade, pela expectativa e pela nostalgia de deixar para trás a pátria, os amigos e a família e os que na despedida manifestam apoio e consentimento, sufocando a dor pela saudade antecipada daquelas pessoas que vão para outros mundos longínquos e desconhecidos e também pela sensação de perda, por estarem diante da possibilidade de nunca mais verem seus entes queridos.

Afirma Magalhães (2002, p.315) que em muitas narrativas - mesmo nas terras do "além-mar", vivendo em intenso conflito bélico, "o mito de um país-emviagem é consistentemente convocado pelas autoridades militares" no dia-a-dia. É como se esse "ser-e-estar" em-viagem fosse uma aptidão constitucional da identidade portuguesa, como uma espécie de incumbência entranhada no modo de ser português. A partir da leitura de diversas narrativas - como Fado Alexandrino, de Lobo Antunes - que trazem à tona a questão da guerra colonial e o momento agonizante do Império Português, a referida pesquisadora observa que mesmo em território de combate e em eventos rotineiros, o comando militar evocava com consistência o mito de Portugal como um "país-em-viagem" para conduzir seus subordinados, mesmo que suas falas apresentassem uma tonalidade irônica. Essa visão estava tão arraigada ao pensamento do português que determinados personagens militares, ao regressarem à pátria, prontamente anunciam uma nova partida, não mais para "lutarem pela Pátria", mas como "emigrante", para

\footnotetext{
${ }^{15}$ Nostos, palavra grega que significa viagem de retorno, volta à casa. Dessa palavra originou-se o termo nostalgia. Nostalgia, que vem do grego nostos (retorno para casa) e algia (dor, aflição). Observa-se que a etimologia da palavra em questão sustenta um teor de grande poeticidade. Nostalgia refere-se então a um suave sofrimento que nos leva, através da memória, de volta ao passado, às lembranças de um universo de experiências vividas no mundo de outrora.
} 
melhorarem suas condições de existências em outros países europeus, ricos em relação à situação periférica em que se encontrava sua terra natal. Cotidianamente, a terra natal era concebida como um "lugar-de-passagem, de não-permanência: um povo em trânsito" (MAGALHÃES, 2002, p.315).

Muitas personagens abordadas pela pesquisadora trazem em si uma eterna insatisfação, uma incompletude diante do real e do presente, o que resulta na acepção de que o contentamento e a realização só virão para o português fora do território pátrio. As décadas de ditadura vividas pelo povo e o enclausuramento vivenciado pela sociedade pode ser um forte fator responsável por esse desejo de estar fora dos limites da pátria em busca de prosperidade. Por outro lado, o estar fora na busca de satisfazer seus anseios "de fazer a vida" também não era sinônimo de realização e plenitude: uma das constatações dessa insatisfação experimentada pelos portugueses fora de seu país pode ser verificada em Percursos, no desconforto, visível aos olhos da protagonista, do pai em relação ao trabalho efetuado na Companhia, pouco valorizado por seus superiores: "sempre por demais subalterno e humilhando-se, vendo-se recusadas possibilidades de promoção..." (p.13-4). Outro exemplo, neste sentido, foi o sentimento de melancolia demonstrado pela mãe por viver longe da família e da terra natal, como se verifica nesta passagem: "[...] era sempre o puto que fazia a mãe torcer-se de melancolia lá na Companhia, de lágrima no olho às vezes e o pai posto em fúria com o espetáculo..." (p. 92).

A expressão de aborrecimento do pai dá a entender, de acordo com o ponto de vista da filha (protagonista), que o Estado e a sociedade lhe haviam criado uma expectativa positiva, mas que, diante da realidade na colônia, fora quebrada, destruindo o ideal de uma vida próspera e de um futuro digno longe da África.

O descontentamento do pai acentua-se tempos depois, quando a protagonista, não mais uma criança, ouve o pai se lamentar, ressentido pelo que acontecera ao Império Português (a descolonização) e, consequentemente, a si, depois de tanto sacrifício e trabalho realizado em África e sem receber nenhum retorno à altura de seu esforço:

Era assim o pai por demais um pau-mandado, pensar que se terá depois ressentido da falta dessa canga, desculpa de que uma vida inteira perdida pelas áfricas e imprevista adescolonização, vida toda de sacrifícios, diria, uma ridícula idemnização e já foi sorte, como não havia de estar ele traumatizado (P. p.13). 
Por um lado, a mãe apresenta o sentimento de saudade de sua terra natal, como uma exilada a habitar numa demora temporária as terras do "além mar", distante dos seus e principalmente de suas filhas; por outro lado, a protagonista de Percursos, nascida e criada em Angola, percebe Portugal não como sua pátria, como lhe fora passado por meio da educação recebida, pois essa personagem encontra-se num "entre-lugar", em que pelas experiências de vida e pela sua acepção política crítica sobre colonialismo, não aceita plenamente a ideia de Portugal como sua pátria, isto é, no mesmo sentido como concebem seus progenitores. Portugal representa, aos olhos da protagonista no momento da narração, o poder opressor. Tendo como parâmetro o pensamento de Halbwachs (2004b) a respeito da memória, em que ao recordar, todo e qualquer indivíduo não o faz sozinho, pois a presença do outro nesse caso, do coletivo - é fundamental, a personagem, ao recordar suas experiências, o faz numa relação dialógica com todos aqueles com quem convive e conviveu ao longo de sua vida, além de seus familiares, enfim, de todos seus iguais e especialmente do povo de raízes entranhadas na terra e cultura angolana, vítima do colonialismo. E assim, por fazer parte de sua memória enquanto sujeito essas pessoas tidas como inferiores pela cultura metropolitana, participam da construção do ponto de vista da heroína em questão, que consegue aproximar-se das evidências da real situação de oprimido do negro e enxergar traços essenciais da vilania característica do país colonizador, ao qual ela deveria conceber como pátria. $\mathrm{E}$ assim mesmo, mantendo uma relação de pertença com o mundo do branco colonizador por origem e formação, a protagonista reconhece a cisão política e social que há entre esses dois povos: angolanos e portugueses (colonizado e colonizador). Desse modo, o exilado não é o português que vive "transitoriamente" na colônia longe de sua pátria, mas sim o colonizado, pois este pode ser verdadeiramente um exilado dentro de sua própria terra, que lhes é invadida pelo branco colonizador. Sem sair do seu lugar de branca portuguesa, por isso, filha e esposa de colonizador, a protagonista assume uma perspectiva favorável aos interesses do colonizado e, assim, ela se sente como alguém "fora-de-lugar", tanto em Portugal quanto em Angola, especialmente no período da guerra como esposa de alferes. Há passagens na obra que exemplifica essa situação da protagonista adulta em Angola na Guerra Colonial, como esta em que a personagem tenta escapar do alvo do olhar curioso dos angolanos ao se proteger numa morada pouco 
confortável e de caráter provisório: "[...] comprar panos [...] espécie de cortinas que haviam de resguardá-los de quem passasse além das grandes janelas" (p. 60). Trata-se de uma passagem que expressa o sentimento de solidão e isolamento vivido pela mulher portuguesa naquele momento em Angola, que se vê diminuída em relação ao que lhe cabiam como mulher, considerando que a razão de estar em África era o fazer do marido, de assumir as frentes de combates. Às mulheres restava apenas a vida marcada pelo tédio e pelo aspecto itinerante de residir em recintos desconfortáveis, provisórios, mas "intermináveis" pela vida enfadonha e de insignificância à qual estavam destinadas. Assim, elas deveriam se dispor a se contentar apenas com a posição diminuta de esposas de alferes, a quem o Império designava a "missão importante" de defendê-lo.

A obra Percursos (1981) foi publicada em um período nevrálgico para Portugal e suas então ex-colônias. O processo de descolonização concluído na década de setenta trouxe consigo, consecutivamente, outro processo relevante, a redefinição das identidades dos países que compuseram o Império Português (metrópole e ex-colônias). Além de tratar da questão da guerra, a obra traz à tona a complexa dimensão da formação identitária do colono português, inserido num "espaço-tempo" marcado também pela complexidade da redefinição da identidade nacional. Mas são especialmente as mulheres, com suas angústias e frustrações nesse quadro de queda do império português, focalizadas na narrativa por meio da personagem principal, que nos apresentam dados textuais relevantes para a compreensão desse processo de redefinição das identidades.

Para melhor delinear o perfil da personagem de Wanda Ramos, é imprescindível que se entenda o papel da mulher portuguesa nas colônias de Portugal em África. Nesse sentido, as duas obras de Margarida Calafate Ribeiro, Uma história de regressos e África no feminino ${ }^{16}$ oferecem importantes contribuições para a efetuação da leitura de Percursos no que diz respeito à presença feminina portuguesa em África. Para a estudiosa, o período da Guerra Colonial, de 1961 a 1974, conta especialmente com a importante presença das mulheres no "além-mar", a acompanhar seus maridos portugueses destinados a trabalharem na Guerra.

\footnotetext{
${ }^{16}$ Margarida Calafate Ribeiro aborda, em África, no feminino, a experiência da Guerra Colonial (19611974) a experiência vivenciada pelas mulheres portuguesa que acompanharam seus maridos na guerra, às quais cabiam, nesse cenário bélico, o papel secundário, pois deviam tão somente apoiar a guerra, estimulando seus maridos e filhos a irem para a África em defesa do Império Português.
} 
Acreditava-se que a presença de suas companheiras thes proporcionaria maior tranquilidade $e$, consequentemente, maior desenvoltura na luta travada. $O$ sofrimento por estarem na Guerra distante de sua terra, de seus amigos e familiares foi, muitas vezes, atenuado pela presença de suas esposas e de seus filhos. A África tornava-se para os portugueses que ali se encontravam "de passagem" um mundo onde nasciam os filhos, que ali cresciam e eram educados segundo os preceitos da sociedade portuguesa. Apesar da distância e da disparidade que separava a colônia da metrópole, na África podia se dissimular uma experiência de vida portuguesa. No processo de colonização, os jovens portugueses que para lá se mudavam poderiam, então, conviver com amigos, comemorar datas e eventos nacionais à distância, além de contarem, ainda, com oportunidades de trabalhos que a metrópole não lhes proporcionava.

O deslocamento das mulheres para a guerra, a exemplo da personagem de Percursos, ou mesmo para participar junto aos homens da política de uma rápida ocupação do território colonial, isto é, de colonização, permitia a conservação da unidade da célula familiar, tão defendida pela ideologia do Estado Novo. Era preciso zelar pela família, a maior responsável pela ordem moral e política do país; se assim o fizesse, o governo estaria cuidando da unidade maior, que seria a Nação portuguesa. As instâncias políticas do poder apostavam na integridade da família como elemento fundamental na manutenção da ordem do regime militar de Salazar e Caetano. Além do mais, a estabilidade criada a partir da presença feminina na guerra contribuía para que Portugal pudesse camuflar ainda mais, aos olhos da sociedade, a existência da guerra, mantendo, assim, uma imagem de normalidade em relação à manutenção do colonialismo, que o regime de ditadura português insistia em propagar. Muitas das mulheres entrevistadas por Margarida Ribeiro (2007, p. 29) reconheceram, em seus testemunhos, a agilidade política do regime em manter as aparências que lhe convinham. Ideologicamente, o poder lusitano deveria passar a impressão de que as opções das esposas de acompanharem seus maridos fossem de índole privada e pessoal, e não de caráter público ou determinadas pelos interesses do Estado. Foi uma forma encontrada pelo governo português de envolver as mulheres na guerra sem se comprometer com o que fazia e sem se sacrificar por algum compromisso assumido com a população flutuante. Desse modo, muitas mulheres portuguesas que acompanharam seus homens na guerra colaboraram com o regime, voluntaria ou involuntariamente, consciente ou 
inconscientemente, para a construção da imagem de paz e tranquilidade que disfarçasse a existência da guerra.

Para além do domínio da vida privada, a presença feminina das portuguesas, conforme o depoimento de muitas delas, em entrevista a Margarida Ribeiro, promoveu um avanço no ensino estabelecido nas colônias. É uma experiência que, na opinião dessas mulheres e conforme o perfil das personagens literárias analisado pela pesquisadora, ganha relevância não só na esfera pública, mas também privada, propiciando-Ihes uma visão mais clara e consistente da diversidade étnica e cultural das populações locais que se misturavam no espaço escolar, das tensões ali geradas e da forma de vida estabelecida nas colônias. Essas mulheres foram, a exemplo da personagem de Wanda Ramos, "colocadas na margem do universo da guerra, vivendo muitas vezes situações de grande isolamento, elas registraram esta experiência, ouviram, observaram, traçaram relações com o poder e foram revelando um "olhar-outro", elaborando uma "razãooutra", sobre as razões do conflito bélico [...]" (idem, p. 29, grifos nossos).

Desse modo, é importante destacar, na abordagem da pesquisadora, que houve um pequeno percentual de portuguesas na África desse período do conflito que fugiu aos traços requeridos e visados pelo governo português. Eram mulheres que compuseram um contorno incompatível com os propósitos do poder imperial e ditador de Portugal, aos quais deveriam atender. Sabe-se, nesse sentido, que houve mulheres que além de acompanharem seus homens, mantinham uma presença ativa e crítica a desvendar a realidade camuflada das relações estabelecidas pela metrópole. Assim, por apresentarem-se indignadas e inconformadas diante das contradições e injustiças praticadas contra as pessoas vítimas do colonialismo, revelaram-se importantes na luta e na pressão a favor de uma mudança sociopolítica dos rumos trilhados pelo até então Império Português.

Nesse sentido, não há na narrativa de Percursos nenhuma evidência de que a protagonista tenha atuado como professora ou mesmo desenvolvido qualquer outro serviço público, como aconteceu a algumas das mulheres entrevistadas pela pesquisadora Margarida Ribeiro. Mas mesmo não participando de nenhuma atividade junto ao público em Angola, a personagem principal apresenta um visão crítica, uma relação com a escrita e com a pintura de modo a quebrar o convencional, principalmente por buscar, por meio da arte da escrita e da pintura, 
lidar com o fragmentário que a experiência e a realidade lhe impunham na construção de um novo "eu" textual.

O olhar de desconforto e descontentamento diante dos eventos que "cindiam" o mundo à sua volta e o mundo do branco e o mundo do negro, revelado pela protagonista ao evocar as lembranças de sua infância e mesmo de sua adolescência e juventude, está evidenciado em diversos momentos da narrativa, como ocorre nesta passagem, situada nas páginas iniciais da obra: "[...] o raro passeio até à piscina-só-para-branco, a formiga quissondo, os diamantes e sua escravidão e terrores, a vida do branco, a vida do preto..." (P. p. 13).

Sabe-se, ainda, que o pós-guerra não foi um espaço-tempo do reino da paz e de tranquilidade, pois semelhante ao que aconteceu com a heroína de Wanda Ramos, muitos casais se separaram. Outros casais mantiveram a unidade familiar, mas sofreram com os desajustes psicológicos e sociais e com os tormentos de terem vivido em África nesse momento tão crítico do conflito. Em se tratando das relações familiares, esses dramas e desajustes psicológicos transferiram a violência da guerra para o seio da família, no espaço doméstico.

Assim, a volta à normalidade, posteriormente ao fim da guerra, recai também sobre a responsabilidade feminina. A guerra trouxe muitas transformações tanto internas quanto externas ao sujeito. Muitas famílias, apesar de se manterem estáveis, lidaram ainda com a memória de um passado tempestuoso e com a cumplicidade do tempo da guerra ainda muito forte nas lembranças. Num longo período que sucede ao conflito, diversas famílias, em suas reuniões e festejos familiares, e até mesmo na intimidade do lar, trazem à tona a memória da Guerra Colonial. Outra forma de reviver as lembranças da guerra era através das viagens em conjunto aos locais da guerra, em que ex-combatentes e demais pessoas que participaram de uma forma ou de outra do conflito bélico pudessem juntos, por meio da memória motivada pelas visitas aos locais de combate, compartilhar da experiência histórica traumática que vivenciaram.

A viagem da protagonista adulta de Wanda Ramos já ao lado do marido militar no período da guerra colonial está em sintonia com a viagem realizada pelo personagem, tempos depois, a seu interior. Há, então, uma ligação representativa entre as duas viagens, que se efetuam por meio da memória, e o resultado dessa última viagem é a própria narrativa. Frustrada em suas expectativas de alcançar a liberdade, a personagem percebe que a vida de casada, confinada nos 
aquartelamentos, agindo como lhe prescrevia os moldes da sociedade portuguesa que para lá a empurrara, é uma continuação "piorada" da vida entediante e de irremediável solidão que levara na companhia dos pais. Tão logo a protagonista percebe que o cotidiano entediante da sua vida não se restringem apenas a si, mas a todos que fazem parte daquela sociedade colonial, em que "à opressão de uma vida familiar e conjugal se alia a repressão do regime colonial" (SANTOS, 2003, p. 23). Desiludida com a forma de vida a qual estava predestinada, sem poder identificar-se com ninguém no espaço em vivia, ela, desejosa de liberdade, vê na escrita outra possibilidade de ser, ainda que, no princípio, essa tentativa não lhe traga de imediato os resultados almejados, como se observa na passagem citada:

\begin{abstract}
Sentava-se em tardes esgotantes uma após outra à espera do milagre do momento do creme de custarda que lhes apaziguaria a nzala acumulada do tédio e da escassez, altas febres de imbecilização formigando-Ihe no sangue e no percurso automático da caneta sobre o papel, hora a hora, o entretenimento vegetante de observar as varias rãs... (P. p. 14, grifos nossos).
\end{abstract}

O percurso da escrita constitui, assim, uma viagem, mas uma viagem para dentro de si, sendo a palavra a única possibilidade de acesso ao futuro. Os fios de memória vão sendo atados, entretecidos para unir os fragmentos e os estilhaços das experiências lembradas, dando-lhes sequência e completude na constituição identitária deste ser em trânsito. A ponderação sobre esse "ser" em constante trânsito na definição da identidade portuguesa é de grande importância para analisar com mais consistência a personagem principal de Wanda Ramos.

A memória, de mãos dadas com o ficcional, tem papel fundamental na reconstrução e interpretação do passado, trabalho este que dá unidade à história da personagem, importante na constituição da sua identidade, já que a vida itinerante assinalada por este vai-e-vem - da metrópole para a colônia, desta para aquela e dentro da própria Angola ao deslocar-se do rio Luachimo para o rio Luena e por vários lugares, especialmente durante a Guerra Colonial - acaba por fragmentar ainda mais o percurso de suas lembranças.

\title{
2.5. Apresentado $O$ berro do Cordeiro em Nova York
}


A narrativa de $O$ berro do Cordeiro em Nova York, cujo discurso se apresenta em primeira pessoa - reforçando seu teor autobiográfico -, trata das experiências de vida da protagonista-narradora, especialmente da sua infância em Mato Grosso, espaço que aparece, a partir do fluxo da consciência, mesclado, na maioria das vezes, ao espaço nova-iorquino da fase adulta da personagem. $O$ desempenho da memória possibilita que passado e presente se juntem, se justaponham ou atuem em concomitância. E é graças à capacidade de rememoração que os espaços distantes e de experiências distintas se encontram ou se sobrepõem.

No entrelaçar das malhas do texto não há nenhum dado verificável que apresente evidências de alguma relação estabelecida entre a personagemnarradora de $O$ berro e a escritora da obra; portanto, como ocorreu no livro de Wanda Ramos, também não há elementos textuais constatados por meio da sondagem desta pesquisa que possa definir essa narrativa como autobiográfica.

O foco narrativo de $O$ berro se atém predominantemente à infância da heroína albuesiana. Com base no período dos acontecimentos históricos referidos no enredo, concomitantes aos fatos de sua meninice, possivelmente os acontecimentos narrados tenham ocorrido no período das décadas de quarenta e cinquenta do século XX. Além do período da infância, o tempo da narrativa ainda se estende para abranger a juventude e parte da vida adulta da protagonista até 0 início da década de noventa, momento da narração. Da mesma forma que em Percursos há dois espaços - distanciados pela situação econômica, social, política e geográfica, que se constituem como elementos relevantes e significativos na composição da narrativa -, no texto de Albues também existem dois outros espaços, fortemente distanciados, com importância decisiva na formação da identidade da personagem principal de O berro: o Brasil (Mato Grosso e Rio de Janeiro) e os Estados Unidos (Nova York). Nely Novaes Coelho (2002) enfatiza que mesmo a "viandante-narradora" das outras narrativas escritas anteriormente pela autora assume declaradamente neste romance sua própria história, retomando, assim, todos seus percursos já realizados, para "reviver" por meio da memória:

a infância/adolescência ansiosa, solitária, sufocada de vida interior, cheia de culpas imaginárias; o encontro com os "iluminados", os perversos e os desamados; as casas habitadas; as viagens pelas sete partidas do mundo [...] tudo, resgatado do passado, terras 
pantaneiras fundindo com o presente, na fervilhante Nova York, e transformando no jorro verbal da escrita catártica (p. 617).

Nessa mistura dos diferentes elementos, a narradora salta do particular, que é o regional, imagens e manifestações culturais características de Mato Grosso, para o mundo. A narradora aproxima, por meio da memória e da narrativa delineada pelo fluxo da consciência, o desconhecido sítio do Cordeiro (parte de um vazio demográfico) da cidade de Nova York, uma megalópole onde transitam ou habitam pessoas oriundas das mais diversas partes do mundo.

O título - O berro do Cordeiro em Nova York - tem uma relação de sentido muito intensa com a temática desenvolvida na obra: o eu da personagem-narradora é projetado para além dos caminhos para os quais suas origens a haviam predestinado. E a escrita do rememorar é o fator preponderante nessa façanha. Diz a escritora em entrevista a um jornal local:

Cordeiro é um sítio onde eu morava quando tinha dois anos de idade. O cordeiro é um animal dócil, que não briga, vai para o cutelo com lágrimas nos olhos, mas não berra. Ele representa o lugar que eu morava e ao mesmo tempo sou eu. Aquela criatura que nunca se conformou com a frase "sou pobre, vou morrer pobre'. E é isso aí. Eu toda vida quis fazer meu próprio destino. Este berro é uma criança que chora com dor de barriga. Este berro chega até Nova York. É uma visão mítica. A história mesmo é uma grande travessia, que vai de Cordeiro até os EUA. Lógico que no meio do caminho, muitas coisas aconteceram. (Folha do Estado, 1995).

Semelhante ao que afirma a escritora na citação a cima, a narradora-protagonista dá a seguinte explicação:

[...] choro de dor de barriga, tenho uma dor de barriga, tenho um novelo de vermes nas tripas, visível pelo volume e movimento que fazem na pança inchada, sinto cólicas infernais, berro, tenho as faces arroxeadas, berro não sei falar, papai me carrega e anda comigo pelo quarto tentando me acalmar, continuo berrando. (BCN, p.12).

O berro contínuo e incansável remete o leitor a um descontentamento da personagem diante dos acontecimentos vivenciados enquanto um traço peculiar, em especial, dessa narrativa, o que se assemelha à insatisfação da protagonista de Wanda Ramos diante da vida que Ihe é imposta pelas condições históricas e sociais do colonialismo português. 
O cordeiro em si ressalta a questão do mítico permeado em toda a escrita de Albues. Nely Coelho (ibidem, p.617) acrescenta que não era a cidade de Nova York que precisava ouvir o seu berro "catártico" (grito), mas sim ela própria. A partir dessa interpretação da critica é possível acrescentar que na instância dos escritos do "eu" está, nesse "grito" de lamento ou denúncia, o espírito narcíseo, na medida em que como na escrita de traços autobiográficos no mito de Narciso, o "eu" que olha é o mesmo "eu" que é olhado. Esse grito "catártico" também tem seu correspondente em Percursos, em que a estratégia do discurso indireto livre e outras formas de manifestação da fala da personagem permitem à protagonista elevar sua voz e bradar seu desconforto. Por meio do uso do pronome pessoal "nós", ela coloca-se como parte de um todo maior, constituído por várias pessoas ou por diversas mulheres que vivenciavam a sua condição:

Deixar apoderar-se dela a noite, de imediato aquela sensação de angústia que se nos instala no espaço à volta sem sabermos porquê, baptismo de áfrica a sério, essa que não é cidades nem vidas, riquezas ou misérias, revoltas e lutas, mas tão-só a ausência, a imobilidade definitiva do espaço que o silêncio atravessa com gume (p. 60, grifos nossos).

Sendo assim, há uma voz própria individual da personagem a contemplar o coletivo, na medida em que o eu manifesta sua dor, que sendo dor de muitas, deve ser acatada por todo um universo de leitores, no sentido de desmascarar a verdade propagada pelo discurso oficial do Estado português.

A visão mítica da narradora de Albues aparece expressamente no texto e a metáfora do nascimento revela um sentido intimamente ligado à complexidade do ser humano, que também está relacionada à figura do rio e da água, tão expressiva no texto quanto o é na narrativa de Wanda Ramos.

Se, de um lado, o Pantanal e os rios em Mato Grosso são componentes expressivos do espaço e do ambiente vivenciado pela protagonista em sua infância, de outro, o rio Hudson, em Nova York, é parte significante da paisagem e do cenário em que estão inseridas suas ações na fase adulta - escritora, mãe e mulher, assim como acontece com o Luachino e o Luena em Percursos. José Alexandre Vieira da Silva (2008), ao realizar uma leitura comparativa de O berro com Os Sertões, de Euclides da Cunha, analisa a imagem das águas presente nas duas narrativas, 
relacionando-a com o conceito da terra prometida e da travessia bíblica do Mar Vermelho. Vieira da Silva destaca o episódio da fuga de Venâncio, o pai da protagonista, do trabalho escravo ao qual o haviam submetido. Sua fuga resgata, assim, o mito da terra prometida e a travessia do Pantanal representa a imagem da travessia bíblica do Mar Vermelho. Nesse caso, não se deve esquecer de notar que a travessia de seu pai apresenta uma natureza sagrada, ao passar pela purificação através do lençol de flores que o cobre enquanto ele permanecia inconsciente e em comunicação com o espírito de seu avô, João Padre, protagonista da outra obra de teor memorialístico de Tereza, Travessia dos sempre vivos (1993). O crítico também aponta a relação que essas imagens têm com o "processo de idealização e construção identitária" (2008, p.01). Para ele, O berro acrescenta mais um número na ordem da sequência das autodescobertas já presentes nas narrativas produzidas anteriormente por Tereza Albues e, assim, utilizando-se da fusão do fantástico com - autobiográfico, busca descortinar sua "identidade fragmentada, frente "a modernidade, problematizando a situação de 'retirante brasileira' em um país do primeiro mundo" (ibidem, p. 02).

A narrativa se compõe de nove capítulos que constituem a metáfora da gestação da protagonista-narradora. O primeiro e o nono iniciam com a expressão "MINHA MÃE ME PARIU DE PÉ” (BCN, p. 11 e 215), reportando, assim, ao nascimento da protagonista, cuja característica de "viandante" está diretamente expressa, tendo em vista que a parturiente estava em trânsito ao dar a luz à protagonista. Assim, o capítulo um pode designar o nascimento da personagem para a vida e o capítulo nove refere-se, nessa perspectiva de leitura do texto, ao nascimento da protagonista adulta já formada para o mundo, considerando que o número nove representa simbolicamente o fim de um ciclo e o começo de outro, o que reforça a tonalidade mítica da narrativa de Albues.

\subsection{Duas meninas em mundos "cindidos" 17}

\footnotetext{
${ }^{17}$ O termo "cindido" é utilizado neste contexto com base nos estudos de Frantz Fanon, para quem "o mundo colonizado é um mundo cindido em dois" (1979, p. 28).
} 
Se aproximarmos as duas narrativas focalizadas neste trabalho, podemos verificar pontos de confluência e de distanciamento entre ambas que permitem uma leitura comparativa bastante produtiva.

$\mathrm{Na}$ "Primeira reminiscência" da narrativa de Wanda Ramos, o texto, constituído distintamente de alguns estilhaços de memória, apresenta um teor descritivo que dá ao leitor ciência de como as personagens se relacionam entre si e como é o espaço principal onde transitavam, tendo como pano de fundo uma sociedade "cindida": de um lado, o branco colonizador, e, de outro, o negro colonizado. A escritora recria o transcorrer da vida cotidiana de uma sociedade delineada pelos traços do colonialismo, em que os brancos invasores sobrepõem-se aos autóctones, rebaixam-nos à condição de total insignificância. Assim, o primeiro capítulo apresenta, de antemão, ao leitor os traços fundamentais do ambiente doméstico e das relações pessoais nele estabelecidas, lugar de onde parte o olhar da protagonista em sua infância. A leitura deste fragmento possibilita também a visualização de como a personagem concebe os dois espaços geográficos relevantes na sua composição, Angola e Portugal, os quais se polarizam em seus principais aspectos. Como já afirmamos em momentos atrás, o conhecimento que a protagonista tinha de Portugal na sua infância era vago, pois the chegava quase que somente através dos conteúdos que a escola a obrigava a decorá-los. Portugal era um lugar de onde se ouvia falar e de onde lhe chegavam os brinquedos, as roupas e outros utensílios incompatíveis com a realidade e com o tempo em Angola, espaço em que vivia a protagonista na sua fase de menina: "Geografia de um continente longínquo de cor, as serras todas, os rios de seguida, os caminhos-de-ferro sem hesitações, as províncias uma a uma" (p.12). O conhecimento obtido pela protagonista no que se refere à Angola era muito mais sólido e profundo que o conhecimento sobre Portugal, pois Ihe chegava através dos diversos sentidos, da experiência de vida cotidiana, do imaginário angolano absorvido por meio das histórias que ouvia e outras que presenciava:

Só sabia dali, chuvadas torrenciais e a terra muito cheirosa depois delas, assustadoras trovoadas com os musseques a arder, as queimadas acarretando farripas de cinza e emporcalhando as cortinas, preciso era fechar as janelas todas; ou então, as imaginadas serpentes no cocoruto das mangueiras, soltavam-se sobre as pessoas para as matar [...] (p.12). 
O conhecimento alcançado pelo sujeito, por meio da experiência, vem acompanhado não apenas de sensações, mas, em especial, das emoções e dos sentimentos vivenciados; por isso, consequentemente, alcança-lhe um lugar mais seguro e consistente na memória e na constituição identitária desse sujeito. Seguramente, essa forma de aquisição do conhecimento pela protagonista é um dos fatores que explicam o fato de a narrativa de Percursos se ater, de forma considerável, às experiências da protagonista em território angolano.

Analisando o episódio exemplar da memória involuntária de Proust, claramente descrita em A Busca do Tempo Perdido, percebe-se que o ato de rememorar está intimamente vinculado às emoções e aos sentimentos de afeto. Nesse sentido, é interessante ponderar sobre uma das reflexões de Halbwachs, em que a memória pode se apoiar muito mais sobre o "passado vivido" que sobre o "passado aprendido pela história escrita" (HALBWACHS, 2004b, p. 75). imaginário também tem papel fundamental como suporte de apoio daquele que se dispõe a recordar as experiências passadas. No caso da heroína de Wanda Ramos, destacam-se as histórias dos costumes e dos hábitos locais de Angola ouvidas e outras vivenciadas. Sua memória era assegurada, então, também pelo que a personagem absorvia do imaginário coletivo, mesmo que de forma clandestina, pois não the era permitido, quando criança, descontrair-se em conversas com os negros, mesmo os criados de sua casa, pois seu pai não via com bons olhos suas inquietudes sobre aquele mundo.

Por diversas razões referentes à forma como se relaciona com o mundo e com o meio onde vive, a criança, em geral, enraíza sua vida, com certo vigor, na sociedade e absorve dela o que há de mais pujante em sua cultura e especialmente em suas relações sociais e afetivas estabelecidas. Desse modo, por mais que os progenitores da protagonista de Percursos negassem todos os rastros culturais peculiares dos povos africanos e afastassem-na, ainda menina, das tradições e costumes locais e dos sentimentos de pertença ao mundo e ao povo angolano, ainda assim, a personagem sentir-se-ia atraída por esse mundo proibido:

[...] horas foram, e desde então entraram os muquixes na sua vida para sempre, e ainda hoje, serão por ventura seu privado maravilhoso, mundo que ciosamente guarda.

E quando já vinham de volta vá de fazer perguntas ao pai, como sempre, e escassa resposta, haveria algum desdém e decerto superioridade no tom com que lhe falava ele, o que sempre a 
desconcertou, pois alguma parca vontade de diálogo sobre coisas incomuns daquela terra bem depressa era cortada por a menina é parva, essas coisas não lhe dizem respeito [...] (p. 33).

A imagem de Portugal como a pátria esplêndida, a metrópole, onde todos que se identificam como portugueses, ao trabalhar na colonização em África, aspiram lá estar, não tem a mesma conotação positiva que tem para seus pais. A visão que a protagonista tem de Portugal é permeada por traços da perspectiva, da visão de mundo apresentada pelos angolanos, que sofrem com a condição de pertencerem a uma colônia portuguesa. A relação de pertença da protagonista é assinalada e talvez até definida pela relação estabelecida com o "outro" (os povos de Angola) no momento crucial de sua formação, que é a infância; dado este que está impresso no termo "puto", que usa habitualmente, como os negros utilizavam para referirem-se à metrópole. Para ela, seria sempre puto, mesmo depois que conhecesse a nova paisagem (p. 370). Ao vê-la sendo arrastada pelos hábitos e/ou linguagem desenvolvidos pelos nativos, os quais acusavam a condição e a resistência do colonizado, corrigia-lhe o pai: "não digas puto, diz Portugal ou então Metrópole, que é para onde vamos, isso de puto é língua de preto [...] a mãe logo de seguida, deixa-a lá Joca, não deixo não, que dirá teu pai com ela a falar prétuguês [...] (p. 37).

Diante desse impasse do encontro de culturas e de povos distintos, a personagem se vê transitando numa zona fronteiriça. Mesmo pertencendo à nacionalidade portuguesa pela origem e pela formação que sua família lhe impõe, traz dentro de si o germe do que virá a ser, enquanto perspectiva de mundo, no momento da narração, considerando que o discurso do narrador, mediador da fala da protagonista adulta e experiente, assumirá uma tonalidade subversiva na interpretação da realidade que apresenta, no sentido de quebrar a "ordem" estabelecida. Para Margarida Calafate Ribeiro, nas análises que faz dos romances semelhantes a Percursos, no que diz respeito à autoria feminina e a abordagem da temática do colonialismo e da Guerra Colonial, como A Costa dos Murmúrios, de Lídia Jorge, e Corpo Colonial (1981), de Juana Rua, o que melhor define esses romances é o movimento de iniciação em que essas mulheres estabelecem no "espaço colonial convertendo as suas protagonistas numa espécie de mulheres póscoloniais, entre homens coloniais" (RIBEIRO, 2004, p. 371). Da mesma forma que Lídia Jorge objetiva em $A$ Costa dos Murmúrios, conforme análise de Ribeiro, 
Wanda Ramos, por meio de Percursos, evidencia o que fora ocultado pela história, sendo esta delineada no passado apenas pelos homens, mas que contou, ao longo dos tempos, com a conivência ou a subversão feminina e, consequentemente, com a força ou a ausência de seu poder. Na leitura de Elza Miné (1997, Percursos é uma obra que se configura como um forte protesto e um "violento ataque à colonização portuguesa flagrada [...] pela rememoração no contexto do quotidiano: pessoas comuns, funções e formas ordinárias de vida" (p. 133). A personagem principal, oriunda da classe média, fiel aos preceitos do modelo familiar salazarista, como muitas outras jovens de sua época, recusa-se a seguir o exemplo da mãe, como figura defensora da ordem familiar tradicional. A solidão não a acompanha só na infância, por exigência do pai, que queria sempre afastá-la do contato com outras crianças, como também perdura no momento em que adulta volta a Angola na companhia do marido. Essa segunda solidão pode estar relacionada à sua maneira rebelde de rejeição aos costumes arraigados mantenedores da ordem social tradicional, pois ela não se junta ao grupo das outras mulheres que viviam a mesma situação que ela. No geral, essas mulheres, diante do contexto conturbado da guerra, viviam entre o espaço-tempo da guerra que elas conheciam por meio das falas de seus companheiros que lá estavam e o espaço-tempo onde elas viviam e conviviam com a angústia e a incompletude definida, em primeiro lugar, pela ausência de seus maridos. Essa situação intermediária da mulher prosseguia na instância espaço-tempo macro, na medida em que elas se sentiam entre o espaçotempo da metrópole, do seu passado ou passado da família e o espaço-tempo da colônia, sempre a imitar o primeiro, onde se encontram no momento presente dos acontecimentos. Como bem define Ribeiro (ibidem, p. 375), essas mulheres delineavam suas relações e prosseguiam numa ambivalência ao conviverem com dois tipos de preceitos, os da metrópole e os da colônia. Suas histórias e sua suas identidades se constituíam no convívio com o entrecruzar de diversos discursos: os proferidos por elas mesmas, os de seus homens, que viviam combatendo na guerra, e o discurso oficial.

Ao observar a primeira parte de Percursos, é perceptível a relação estabelecida pela protagonista com múltiplos discursos, mediados pelo narrador da obra. Há o discurso da mãe, passivo como esposa e autoritário como senhora branca junto a seus empregados, e o discurso do pai, ora autoritário e repressor ora ressentido por entender que não recebera de seus superiores o reconhecimento 
suficiente pelo trabalho que realizara na Companhia. Em contraposição, a personagem se deparava ainda na infância com o discurso dos nativos, por meio dos quais tinha acesso ao imaginário, às raízes, às narrativas e aos costumes locais.

Sabe-se que a memória viabiliza ao sujeito unir a experiência de vida concebida pela criança às ponderações que, como adulta, no momento da narração, a personagem é capaz de conjecturar e articular sobre o passado. O curto espaço de tempo da sua vida de criança não the dera maturidade suficiente para estabelecer comentários e predefinir conceitos a respeito do que observara na realidade. É o conhecimento amplo, profundo e crítico do presente, quando ela já é uma adulta, adquirido pela sua elevada formação acadêmica, que vai the permitir ponderar sobre os acontecimentos que experimentou na sua meninice, assinalada pelas dúvidas e pela curiosidade infantil, que, no caso da heroína em questão, ficaram em aberto, sem respostas, como se constata nesta passagem da "Décima quarta reminiscência":

[...] vá de fazer perguntas ao pai, como sempre de escassa resposta [...] alguma parca vontade de diálogo sobre coisas incomuns daquela terra bem depressa era cortada por a menina é parva, essas coisas não lhe dizem respeito [...] não lhe gostava perguntasse aos criados alguns porquês que lhe estalavam na cabeça [...] (p.33).

Ao caracterizar o pai em sua condição de subalterno, a canalizar todas suas forças de trabalho em favor da Companhia (Diamang), a narrativa alerta-nos para os traços peculiares da identidade do colonizador português, cuja existência não só implica na existência do colonizado, mas de si próprio também como um subalterno. Trata-se de uma questão apontada pela protagonista que evidencia a situação política, econômica e social de Portugal como um país semiperiférico em relação às demais nações do primeiro mundo. Se na "Terceira reminiscência" a protagonista ataca abertamente a subalternidade do pai, funcionário da Diamang, essa companhia, na "Segunda reminiscência", constitui o espaço restrito e fechado, no qual todas as pessoas ali, brancas ou negras, deveriam estar confinadas. Para melhor entender os traços que definem o colonizador português, nesse espaço dominado pela Diamang, descrito pela obra, é preciso considerar que não se trata de uma empresa puramente portuguesa, na medida em que sua constituição, a partir de 1917, deu-se a partir de um capital misto, oriundo de grupos financeiros 
pertencentes a vários países: Portugal, Bélgica, Estados Unidos, Inglaterra e África do Sul.

Para melhor analisar o perfil social e político do pai da protagonista, como está posto na narrativa, é importante que se lance mão das ponderanções de Boaventura de Sousa (2002) sobre as figuras do "própero" e do "caliban", para quem Portugal é um país semiperiférico no sistema mundial do capitalismo moderno desde o século XVII. Seguno opinião de Boaventira, por mais que a socieade portuguesa moderna tenha se transformado ao longo dos séculos, Portugal sempre se colocou no processo de desenvolvimento econômico numa posição de intermediação entre os grandes centros e os países da periferia da economia mundial e nunca ocupou a posição dos países centrais. Deve-se considerar, então, sua incapacidade para colonizar efetivamente, pois fora ele próprio uma espécie de colonizado também. Trata-se, assim, de uma dupla colonização, pois Portugal fora dubiamente um "próspero" e um "caliban". Fora indiretamente colonizado "por parte dos países centrais (sobretudo a Inglaterra), de quem a nação portuguesa foi sempre dependente (por vezes de modo quasi-colonial)" (SANTOS, 2002, p.24). Se Portugal era, em relação às suas colônias, o centro, era também a periferia em relação à Inglaterra.

Enquanto cultura européia, a cultura portuguesa se constituiu como periférica, assumindo assim o posto de centro em relação às demais periferias fora do continente europeu. Daí, Boaventura Santos constatar o acentrismo como uma das principais características da cultura portuguesa, pela sua dificuldade em definirse identitariamente em relação ao exterior e também no interior de si própria. $O$ acentrismo acontece a partir das incorporações e apropriações de culturas diversas, ocorre por intermédio das incorporações de outras culturas e da habilidade dos sujeitos de transitarem diretamente do local para o transnacional, sem antes passar polo nacional.

A dificuldade de diferenciação e de identificação da cultura lusa, ao mesmo tempo que constitui um vazio significativo no sentimento de pertença do português, consolida um espaço e uma forma cultural caracterizados como fronteiriço. Mas o que é peculiar ao sentimento de pertença do português é que o vazio não se situa no lado externo, em "terra de ninguém": o vazio está do lado português. Constatada essa realidade, Boaventura pondera que "no trajeto histórico cultural da modernidade", o português foi tanto europeu quanto "selvagem", foi tanto 
o colonizador quanto o emigrante (SANTOS, 2000, p. 152). A nação portuguesa não se acomodava dentro dos parâmetros dos demais países imperialistas, por se caracterizar como dependente de outra potência, e também não se considerava e nem era visto como país europeu por ainda abrigar, como regime político, uma ditadura e esta não mais convinha ao discurso ocidental preponderante.

Há, na narrativa de Percursos, certa incompatibilidade entre os trajes, as vestimentas e outros objetos da protagonista e de sua família vindos de Portugal, mas que se tornavam incompatíveis à cultura e à realidade de Angola:

E os inúteis brinquedos que de lá vinham, mandados pela tia beata e solteirona, os avós, portadores de mundo desfasado, necessariamente mitificado nos servicinhos de plásticos às florinhas, nas panelinhas de alumínio, nalgum tecido de mais rica textura ou estampado, supostamente mais à moda, vestir a menina de folhos, organzas, e cambraias por entre os calores e poeiras africanas, laçarotes no cabelo, fitinhas cetim - pois não era frustrante vesti-la somente com os tecidos de lá, tobralco, róbia, algum escasso pano importado das Américas, que o outro mais ordinário empilhado ( $p$. 12, grifos nossos).

Nesse sentido, é importante observar qual imagem de Portugal é repassada em sua colônia. O Portugal que se faz representar em Angola é um Portugal "retificado e elevado pelos critérios da civilidade burguesa de que se apropria e que no sentido estatístico do termo, normaliza" (NUNO PORTO, 2002, p. 235). Houve, por parte do português em terras do além- mar, uma preocupação em forçar o quanto pôde para manter sua antiga identidade, conservar seus costumes, suas formas de vida, usando os mesmos utensílios, as mesmas roupas que usavam em Portugal, mesmo sendo inadequadas às novas situações. Por mais que rejeitassem e negassem a cultura local, essa se fez presente, misturando com os elementos oriundos da metrópole. Por razões como essa, os enfeites pessoais e vestidos requintados da protagonista misturaram-se bizarramente "aos colares e poeiras africanas" (p. 12).

O tédio e a falta de sentido à vida, isto é, o vazio existencial experimentado pela personagem, está na forma de vida levada pelas famílias de portugueses, cujo quotidiano está centrado nos objetivos da Companhia de exploração de diamantes. Num tom irônico, a protagonista ressalta que o destino e todas as necessidades das pessoas que vivem em sua comunidade, da alimentação até algumas parcas formas de lazer, ficavam à mercê dos comandos da Diamang: 
E a Companhia disse e fez, e mandou, autorizou, reconheceu, recusou, reprimiu, compensou, irou-se, despediu, promoveu, explorou, contratou: a Companhia abstracta entidade, deus todopoderoso anichado nos terrores quase supersticiosos de quantos ali dividiam os dias entre os iluminados símbolos do orgulhosamente sós, entre o bolor e a canga (p. 13).

Nessa passagem, as lembranças da protagonista chamam a atenção do leitor para a desvalorização humana diante dos interesses do capital representado no trecho acima pela Companhia. Passa-se a idéia de que as pessoas, independentemente de sua pertença, classe social e origem, são massa de manobra da Companhia. Tem-se a impressão de que as ações de opressão e de extremo controle exercido sobre a comunidade ao comando da Companhia, consubstanciado ao colonialismo, não partem da vontade de seres humanos reais, mas sim de algo superior e invisível. Passa-se a ideia de que a Companhia, como qualquer outra empresa constituinte do sistema capitalista, não dependia de pessoas para colocá-la em funcionamento. A Diamang se constituía como um ser supremo e onisciente, despido de qualquer sentimento de afeto e compaixão para com seus subordinados. Nessa constatação referente às injustiças sociais do colonialismo nas imediações do espaço onde a protagonista passa sua infância, a escritora Wanda Ramos apresenta um distintivo, em que, de um lado, colocam-se as pessoas que estão em Angola, tanto colonos quanto colonizados, e, de outro lado, a Companhia, que, como já se observou, representa o poder, o capital, por trás do qual estão os grandes empresários, pertencentes, na maioria, a outros países, países ricos, em relação aos quais Portugal se posiciona numa condição periférica, ou seja, uma espécie de caliban do caliban.

Sob o comando da Companhia encontrava-se tanto o colonizado quanto o colonizador, ainda que a um dos lados recaia o ônus maior:

[...] tudo da Companhia, os homens também, as mulheres, as crianças lá nascidas e não, os pretos, os brancos, os mulatos, e ainda as casas e os jardins destas, as ruas de terra encarnada batida, o raro passeio ao domingo até à piscina-só-para-branco, a formiga quissondo, os diamantes e a sua escravidão e terrores, a vida do branco, a vida do preto - tinha a Companhia tudo isso e muito mais [...] (p. 12). 
Numa linguagem marcada pelo tom de ironia e de indignação, Wanda Ramos usa a expressão "piscina-só-para brancos," grafada como uma só palavra composta, na medida em que as palavras estão ligadas por hífen, estratégia de cunho literário que dá a ideia de uma determinação sólida que garante um costume já consolidado na meio social e, assim, o texto dá ênfase a essa organização política e social de divisão do espaço, o do branco e o do negro, cabendo a este último apenas o trabalho fatigante. A visão crítica da personagem - que volta e meia submerge à voz do narrador, a ponto de evidenciar essa cisão como uma forma bastante definida da injustiça e da miséria entre os povos envolvidos -, é consequência do patamar de conscientização das relações sociais estabelecidas em uma realidade cindida, atingido pela sociedade a partir do processo histórico, e é, em especial, nesse caso, fruto das relações instituídas pela protagonista com o meio em que passara a infância, constituído essencialmente pela presença do negro e de sua cultura, no papel de criado em sua casa paterna. Mesmo tendo seu saber e cultura negados pelo branco, o negro que trabalha na residência do colonizador tem muito a contribuir na formação das crianças brancas que ocupavam aquele espaço. Mesmo que a interação entre o criado e a criança ocorresse de forma rara e superficial, só a presença cotidiana do negro diante do olhar curioso da menina já seria suficiente para levá-la a conjecturar, na sua simplicidade de criança, a forma de vida levada pelo outro.

Sabe-se que a criança é capaz de mergulhar nos meios sociais de onde traz para si a história de sua família e de sua comunidade, mantendo uma relação de certa proximidade com um passado mais ou menos distante, na formação do complexo de suas lembranças pessoais (HALBWACHS, 2004b). De modo geral, numa sociedade dividida em classes, com a ausência dos pais a ocupar-se dos seus afazeres na fase adulta, as crianças da classe favorecida mantêm proximidade com os velhos da família (os avós) e também com os empregados da família, de quem recebem várias noções distintas daquelas dadas pelos pais ou pelo conteúdo escolar. A criança recebe desses grupos sociais, de condição subalterna, com quem divide o mesmo espaço da casa materna, um conhecimento que lhes é especial, desprendido e despretensioso, pois não Ihes exige esforço e ainda lhes dão prazer, porque quem lhes passa o faz espontaneamente, por não ter nenhuma responsabilidade com a sua educação, sendo essa função exercida rigidamente pelos pais. Nesse sentido, em Percursos, a solidão da menina portuguesa é 
quebrada no dia-a-dia, algumas vezes, pela companhia do angolano (mulher e homem) a se ocupar do trabalho doméstico. Desse modo, o convívio com essas pessoas lhe mostra um outro mundo e uma outra possibilidade de olhar para a vida e para o outro, o que torna a protagonista do tempo da narração, em sua forma de pensar o mundo, muito diferente dos seus progenitores. Assim, o vínculo com a história e com os princípios morais e tradicionais da cultura portuguesa, diante dos acontecimentos analisados anteriormente, não ganha solidez, mas fragilidade diante da experiência vivida pela personagem a presenciar a visão e a cultura do colonizado.

Do outro lado do Oceano Atlântico, distante daquela Angola cindida pela colonização portuguesa, numa terra - Brasil, mais especificamente, em MatoGrosso -, cuja independência de Portugal se deu há quase um século e meio, lemos que a protagonista de $O$ berro, para entrar na casa dos patrões de seus pais, só Ihe era permitida a porta dos fundos, entrada que condizia com a sua condição social e econômica.

A narradora-personagem fala com rancor e ressentimento da humilhação a que foi submetida na residência dos patrões de seus pais: "Segundo os conceitos da casta de dona Isabel eu trago o estigma da pobreza estampado na testa desde o nascimento, devo me trajar e me comportar como tal [...]" (BCN, p. 156).

Em Percursos, foi o "senhor padre" que orientou a protagonista a fazer a primeira comunhão sem nenhum constrangimento. Certamente essa relação tranquila entre a personagem de Percursos e a autoridade da Igreja seja decorrente do fato de que a personagem pertence ao lado do colonizador, o qual é defendido pela Igreja Católica. Lembre-se a respeito que, segundo Fanon, na África, no período da colonização, a Igreja agia como um "intermediário" a favor dos representantes do poder. O estudioso, referindo-se à realidade das colônias dos países europeus na África, argumenta que a Igreja não conduz o homem para "a via de Deus mas para a [...] via do patrão, a via do opressor" (1970, p. 31) Em O berro, a mesma via é trilhada pela Igreja, já que a sua proteção vai para a classe social do lado oposto ao da personagem principal, que é obrigada por dona Isabel, patroa de sua mãe, a passar pelo sacramento da comunhão, como todas as outras crianças de seu meio e classe social.

A menina mato-grossense se ressente também pelo preconceito sofrido pela sua cor de pele, pela sua aparência física incompatível com os padrões sociais 
estabelecidos. A rejeição sofrida fora de casa é ainda mais forte no meio familiar, pelo fato de a personagem parecer-se com o pai, de quem herdara sua cor escura, e ambos, por isso, eram tratados com desprezo e discriminação pela família materna, que se definia como branca.

Em Angola, para a menina branca, cujo pai possuía o status de ser branco e "ser da administração", o momento da primeira comunhão constituiu-se como uma oportunidade de se "misturar com os outros meninos [...] o filho do mecânico, o filho do serralheiro" ( $P$, p. 17) e sair do isolamento em que vivia. A primeira comunhão para a personagem mato-grossense tornou-se uma espécie de "terror", que é ressaltado pela narradora com a comparação que faz do sacramento com o recrutamento do pai, em 1932, para lutar na Revolução que eclodira em São Paulo. O acontecimento foi para ela como um "ritual de imolação" pelo qual deveria passar: "[...] pesadelos só para atrasar a minha imolação" (BCN, p. 59). As comparações efetuadas, as expressões refletiam o ressentimento experimentado na infância ainda são vivenciados pela personagem no momento da narração.

A menina da obra de Albues, na condição de oprimida e desolada pelo olhar das outras meninas de famílias abastadas, junta-se às outras crianças de sua classe, demonstrando, assim, que a Igreja abordada no texto, além de funcionar a favor da classe opressora, acolhe seus fiéis de forma dividida, apresentando claramente um espaço para os pobres e outro para os ricos: "Vi na ponta do banco duas meninas encolhidinhas, tímidas, escurinhas, vestidas iguais a mim, sentei-me perto delas, me encolhi também. As outras nos olharam com desprezo e uma lourinha de mãos enluvadas nos apontou dizendo, olha só as criadinhas de dona Isabel " (p. 60). Essa divisão social tratada por Albues no que diz respeito ao espaço da Igreja ocupado pelas crianças de acordo com a classe social e econômica destas pode ser comparada em Percursos com as passagens em que a protagonista portuguesa está sempre atenta para a relação de superioridade que o branco estabelece com o negro.

Assim, na narrativa portuguesa, há uma menina branca vivendo no meio de negros e na narrativa mato-grossense há uma menina negra no meio de brancos, ambas padecendo diante das injustiças cometidas contra o negro e contra os trabalhadores. O olhar de indignação da narradora-personagem de $O$ berro - ao tratar da exploração vivenciada por seus pais e por toda a sua família em Mato Grosso, onde passaram por situações de extrema barbárie, em decorrência das injustiças e 
opressões estabelecidas contra os menos favorecidos pelos grandes proprietários de terras, como o trabalho escravo a que foram submetidos no "latifúndio do Pantanal", experiência situada no topo da escala dos eventos que lhes causaram desconforto e sofrimento - revela que a vivência contínua em condições máximas de vítima da opressão e da tirania, estabelecida pela da exploração uma classe social sobre a outra, deixou fortes seqüelas em todos. A pior delas foi a loucura do pai, anunciada pela narradora como fruto da dor, do medo e de todo o sofrimento que experimentou.

Numa sociedade em que a figura paterna era considerada "a cabeça" da família, a loucura do pai desestabiliza ainda mais a base de formação da protagonista, o que a deixa ainda mais insegura diante da realidade. considerando que, na primeira infância, a menina necessitaria muito do apoio que seu pai deveria Ihe proporcionar. Essa situação está clara e concretamente revelada pela seguinte passagem: em que é narrada sobre o chão que deveria dar sustentação aos pés da personagem, que, na sua tenra idade, descia da chalana para viver certamente o momento mais trágico da sua existência: "Sensação de desamparo, estranheza quando pisei o chão mole minando água, tive medo de afundar até o pescoço [...] meus pés me alertaram que tocavam um solo que não se podia confiar por quê? Segurei firme as mãos fortes e calejadas de papai, precisava de proteção..." (BCN, p. 22-23). Com a loucura, a estrutura familiar ficou fragilizada e os problemas econômicos acentuaram-se, acontecimentos esses fundamentais na definição dos fatores determinantes do tipo de relação estabelecida pela personagem com 0 mundo durante as demais fases de sua vida, embora já tivesse experimentado outros momentos de insegurança.

Há ainda outros elementos de ambos os romances que gostaríamos de ler comparativamente. Para tal, retomaremos o momento da primeira comunhão de ambas as personagens. Analisando de forma comparada o momento das narrativas que tratam das vestimentas das personagens, destaca-se a passagem referente à primeira comunhão em Percurso e em $O$ berro. No texto de Wanda Ramos, é interessante ressaltar a incompatibilidade do estilo e do refinamento dos trajes usados pela personagem não só no momento do sacramento, mas nas diversas situações importantes de que participava, no ambiente da colônia, onde se encontravam ela e os pais, definido, muitas das vezes, pelo calor forte e pela poeira a cobrir as pessoas e a paisagem: no sacramento da primeira eucaristia, "vestiramna de organdi branco com folhinhos e bolsinha do mesmo onde..." (p. 17). No geral, 
em Percursos, a protagonista se apresenta nos momentos e locais especiais vestida com "[...] tecido de mais rica textura ou estampado, supostamente mais à moda, vestir a menina de folhos, organzas e cambraias por entre os calores e poeiradas africanas, laçarotes no cabelo, fitinhas de cetim [...]" (p.12), o que define não só a condição social e financeira de seus familiares, mas também parte do funcionamento cotidiano de uma sociedade colonial, em que o colono quer, a qualquer custo, imitar a vida na metrópole. Colocada no lado oposto à protagonista portuguesa quanto à cisão social, a personagem de Albues se olha como "a menina mais mal vestida" (BCN, p. 60) entre as demais que participam da referida cerimônia. De acordo com sua autodescrição, o evento, que era um momento célebre e de "glamour" para as filhas de famílias abastadas, era para as filhas de famílias desprovidas uma espécie de tormento e humilhação, em que sua pobreza ficava ainda mais evidente aos olhos dos outros: "olhei para mim: meu vestido, um camisolão; o véu de filó grosso que em Cuiabá se usava pra fazer mosquiteiro; a grinalda, um arame encapado de morim rodeado de rosas brancas de papel crepom" (Ibidem).

Observa-se que as duas protagonistas revelam o incômodo experimentado por elas por perceberem que suas vestimentas não estavam em sintonia com o meio social e nem com a ocasião da qual faziam parte. Conforme a descrição da vestimenta da protagonista de Percursos, comparando-a com a protagonista de $O$ berro, ela não seria uma de suas iguais, mas sim uma (conforme apresentavam suas vestes) que ocupava o polo oposto à sua posição na sociedade, em nível semelhante às filhas de famílias de posses em Mato Grosso, recriado por Tereza Albues: elas "vestiam seda pura, tafetá, organza, crepe de seda [...]" (p. 60). Mas o fato de ocupar um lugar privilegiado em relação às demais pessoas de seu mundo e de se vestir com o requinte das roupas feitas com tecidos vindos da metrópole não faz a protagonista de Percursos tão mais feliz que a protagonista de Albues.

Na visão da heroína de Wanda Ramos, suas roupas usadas na infância são inadequadas à realidade africana. Observa-se, ainda, que a perspectiva do narrador nessas passagens acima citadas, referentes à infância da personagem, é muito mais contagiada pela visão crítica da mulher experiente e transgressora do tempo da narração que pelas sensações de insatisfação e de vacuidade vivenciados na infância. Sentimentos estes procedentes do "sentimento de não pertença" como causa de sua posição de "entre-lugar" constituído pelos dois polos opostos que balizam o colonialismo: colonizador e colonizado. As duas heroínas se diferenciam 
uma da outra não só pela posição que ocupam na sociedade, mas, especialmente, quanto à visão de mundo e de sujeito de cada uma delas.

A relação de poder estabelecida entre as classes sociais e a relação do ser humano com o mundo, expresso na figura de outros seres vivos, caracterizadas pelo desrespeito e até mesmo pelo sadismo, são claras e minuciosamente abordadas pela narradora-personagem da obra mato-grossense, que relaciona, no mundo atual, esses eventos de crueldade, de barbárie e de falta de compaixão do ser para com o "outro" (seja ser humano ou um animal) com as injustiças e as opressões vivenciadas pela personagem, as quais foram decisivas na sua formação da infância à juventude. Assim, o poder opressor de dona Isabel, em O berro, a espezinhar os pais e a própria protagonista ao longo da vida vai sendo substituído por outros da mesma estirpe, exercidos em maior ou menor intensidade, como a estrutura de poder do Estado, funcionando sempre em prejuízo da maioria subalterna: nas atitudes do patrão que humilhara a personagem já crescida no Rio de Janeiro; no prazer do homem em engaiolar passarinhos; nas brincadeiras atrozes com animais efetuadas por seres humanos, como a "farra do boi" (p.38) e na opressão vivenciada pelas pessoas do chamado "terceiro mundo", que, muitas vezes, pelas crises econômicas pelas quais passam seus países, são obrigadas a abrir mão de sua terra, de sua cultura e de sua família para viver em terras estrangeiras, como se observa nas duas passagens a seguir: "Quantos Severinos eu tenho encontrado nos Estados Unidos, brasileiros [...] que tentam desesperadamente se americanizar macaqueando trejeitos e costumes que nada têm a ver com a sua formação" ( $p$. 136).

Quando fomos arrancados do Cordeiro, nós, plantas tropicais sofremos a tortura do esmagamento cultural, vertemos o sumo oculto do equilíbrio climático, sobrevivemos a tudo e ainda demos flores e frutos ligados que estávamos por aquele cordão umbilical à placenta teimosa do cerrado? (p. 239).

Neste trecho da obra, a narradora nos chama a atenção para a ligação determinante estabelecida pela personagem com o espaço de onde veio, o cerrado, o qual nos impressiona pela capacidade de regeneração, mesmo após devastada por um forte fogo, tem a força de rapidamente brotar e recuperar seu vigor. Ao se identificar denotativamente com o cerrado, a narradora-personagem albuesiana sugere que os obstáculos superados, constituídos por tudo que classificara como 
desumano e injusto, ajudaram-na a tornar-se forte, constante - como a árvore do cerrado, pequena, retorcida, lenhosa, mas capaz de adaptar-se e superar as dificuldades oferecidas pelo solo, pelo clima e pelo fogo e dar flores e frutos - e persistente em fazer da dor e da indignação, diante do vivido, substâncias e estratégias de sua criação: "As nossas experiências foram passageiras, enfrentamos tribulações e delas saímos airosamente escrevendo sobre o tempo das vacas magras" (p. 239). De forma semelhante, veremos, em momentos posteriores, que a protagonista de Percursos também vai fazer do tédio, da solidão, do vazio experimentados diante das condições de vida impostas à criança e à mulher portuguesas pelo colonialismo e pela Guerra Colonial combustível para sua criação literária.

\subsection{A luz de um novo olhar, apesar da Guerra Colonial}

Estar em África por causa da guerra foi, para muitas mulheres e para certos homens, também uma oportunidade de melhor conhecer a realidade do Império Português, constituído por um vasto território, comandado por um minúsculo país.

No período da guerra, muitas jovens mulheres de alferes milicianos convocados para a guerra (universitários de boa família e de boa formação acadêmica) viviam confinadas nos aquartelamentos, em espaços exíguos, quartos restritos, "varandas, salas, lojas, halls de hotéis, tabiques, banheiras, camas e casa de banho" (FARIA, 2002, p. 2-3). De forma semelhante a essas mulheres, a personagem principal de Percursos também vivia em situação de desconforto; estar em Angola constituía, para as mulheres portuguesas da sua condição, um estado provisório sem nenhuma estabilidade, por mais que durasse o tempo vivido ali na colônia, pois, conforme se pensava a maioria, a vida só poderia ser próspera na metrópole, mas com as devidas vantagens obtidas no além-mar. Como não participavam das ações de combates e não lhes cabia o trânsito de um lugar a outro, a condição feminina naquele contexto da guerra só lhe permitia a viagem interior que fazia através da memória, do imaginário e da escrita.

Vivendo na retaguarda, mulheres como Wanda Ramos, em Percursos, Juana Ruas, em Corpo colonial, e Lidia Jorge, em $A$ costa dos murmúrios, e, por isso, conhecendo os bastidores da guerra, essas mulheres, como afirma Faria, 
foram capazes de elaborar sua versão sobre o conflito, distinta da perspectiva masculina, pois conseguiam expor aquilo que era camuflado pela informação oficial do Império. Ao assumirem a instância discursiva e construindo seus romances e seus personagens, que tinham como pano de fundo e cenário de suas ações a sociedade colonial e os bastidores da guerra, estas colocaram em cheque 0 discurso tradicional. O texto de autoria feminina acabava por desmistificar os heróis constituídos pela versão oficial. E, assim, a abordagem do tema, de caráter social, histórico e político a respeito da realidade da guerra, configurava-se como motivos para se tratar de outros temas também relevantes para a literatura, como: a tessitura da escrita literária; a natureza memorialística e autobiográfica dos textos; o feminino e sua relação com o companheiro, com os pais e com a sociedade em sua complexidade; a necessidade de libertação de um passado traumático, marcado pela opressão, pelo desamor, pelo tédio e pela repugnância.

Como se observa neste trecho a seguir de Percursos, a autora constrói uma situação por meio de uma linguagem irônica que expressa a visão crítica da protagonista (isto é, mediada pelo narrador em terceira pessoa), preocupada em focalizar uma faceta de determinada parcela da população portuguesa em África, que apesar de ocupar o espaço superior em relação ao colonizado, age de modo medíocre e moralmente inferior ao negro no dia-a-dia de suas relações familiares:

Era a caranguejola de duas classes, como seria de prever, uma para
brancos na parte dianteira e a outra para pretos atrás, e igualmente
de duas classes a atmosfera, enfatuada e enfastiada, ressumando
basófia de portugas quase analfabetos e pobretanas, de mulheres
destes arreadas à moda da cidade esbofeteando a torto e a direito
as proles, desfeitas estas em berros e vómitos e caca e empestando
o ar de cheiro e choro, e lá atrás, por entre a exterior discreção de
indígenas paredes-meias com branco, por necessidade da vida lá
deles subidos até alguma vitória ou mesmo à capital, sobressaindo
do mar de trouxas e panos e lenços garridos, a vozearia solta e
cantante das mulheres dando ostentamente de mamar aos filhos e o
tom levemente mais grave, algo compenetrado dos homens delas
(p. 62 ).

Em oposição à figura degradante do dominador no quotidiano dos bastidores da guerra em Angola, o negro aparece com uma imagem positiva. O refino e a nobreza dos nativos se opõem à aparência e à conduta "deplorável" do português, ironicamente chamado de "portuga" pela personagem, que observa nele uma espécie de procedimento hipócrita para manter as aparências. O ser português, 
nesta passagem, revela também a condição deplorável do Império Português não só por se tratar de um período da Guerra, mas especialmente pela sua situação em relação aos demais impérios a ocuparem a África colonizada: como já foi observado nesta pesquisa, trata-se de um "próspero calibanizado".

Utilizando do processo natural da memória, que, como já se observou, age por concomitâncias, depois de usar a locução temporal "lá atrás", evocando a participação do leitor, o narrador sobrepõe uma cena à outra para que o leitor, sem as evidências habituais da narrativa convencional, automaticamente visualize a cena não dita, mas subentendida. Acostumado aos moldes da narrativa tradicional de sequencia lógica, quem lê a referida passagem anteriormente citada, ao depararse com a expressão "e la atrás" - situando possivelmente a presença dos negros, ocupantes dos bancos traseiros da camioneta - espera por algumas descrições, referencias desses elementos e aspectos da cena sugerida, mas o que se espera fica elíptico e o que aparece escrito é uma outra cena, com personagens representantes da mesma divisão social da cena anterior, mas agora ocupando praticamente o mesmo espaço, como consta nesta expressão: "indígenas paredesmeias com branco".

\subsection{A infância através do entrecruzar de olhares}

Se em Percursos há uma visão crítica por meio tanto do olhar e da postura do feminino na narrativa, em $O$ berro a protagonista narradora apresenta uma crítica embebida de forte dramaticidade que provém, muito mais, de em grande parte, do seu olhar de menina, dos seus ressentimentos diante dos fatos vividos na infância do que da visão ampla e experiente da narradora adulta. Os juízos e as análises emitidas em $O$ berro apresentam proximidade entre quem narra e a personagem que vive os fatos. O discurso da narradora quase sempre revela um tom rancoroso e de revolta, no sentido de estabelecer com o leitor uma empatia que o leve a se condoer pela situação dramática experimentada pela personagem na infância. Já Wanda Ramos, em muitos momentos, expressa um olhar de maior distanciamento em relação aos acontecimentos relatados, no sentido de que o narrador não se deixa contaminar tanto pelo ressentimento e nem pelas emoções e rebeldias experimentadas pela personagem quando menina, como 0 faz Albues. As protagonistas, nas duas obras - a albuesiana, de forma mais acentuada -, ao 
recriarem as lembranças de seus passados, encontram uma forma de exorcizar ${ }^{18}$ os traumas e os ressentimentos adquiridos a partir das turbulências vividas em tempos de outrora.

No geral, os textos de teor memorialístico e autobiográfico apresentam considerável complexidade com relação a esse afastamento de perspectiva do eu narrador em relação aos fatos de sua vida relatados. Se, por um lado, o distanciamento entre o tempo da narrativa e o tempo da narração neutraliza o envolvimento emocional do narrador com as experiências, permitindo-Ihe ponderar com mais profundidade sobre o que conta, por outro lado, esse mesmo distanciamento lhe permite usufruir mais experiência, maturidade e consciência das injustiças e iniquidades que presenciou na infância, as quais foram aceitas, muitas vezes, com certa passividade. Sabe-se que o ressentimento ${ }^{19}$ só começa a fazer parte do emocional das pessoas quando estas tomam consciência do que é justo ou não, conforme os valores morais e religiosos. E essa tomada de consciência acontece, muitas vezes, por meio da experiência e do conhecimento que só chegam com a maturidade, que, por um lado, leva o sujeito narrador a olhar para o que viveu em um passado remoto de sua existência como personagem, de forma crítica e analítica, isto é, recorda de suas experiências se colocando com certo distanciamento, mas, por outro lado, o ressentimento pode contagiá-lo, trazendo-Ihe a revolta e a dor diante do vivido remotamente. E é nesse sentido também que o "eu" narrador pode, por meio do feito narrativo de suas memórias, exorcizar aquilo que lhe angustia.

Se no âmbito do comportamento humano o ressentimento se caracteriza pela presença de um sujeito passivo diante das injustiças que julga ter sofrido, em $O$ berro, a protagonista reage para se desvencilhar do "visgo", isto é, do meio que a aprisiona aos princípios morais e religiosos arraigados, para transformar suas condições de vida e a si mesma, não se prendendo unicamente ao ressentimento,

\footnotetext{
${ }^{18} \mathrm{O}$ termo exorcizar, ligado especificamente ao processo narrativo e à memória, tem por referência a sua utilização por Izabel Allegro Maglhães ao se referir ao texto de Lígia Jorge, A Costa dos Murmúrios: "a primeira parte do romance sobre os tempos de guerra em Moçambique testemunha presencial dos acontecimentos, que procura (re)construí-los ou exorcizá-los através da sua narração (2002, p. 317).

${ }^{19}$ Conceito utilizado com base na acepção de Maria Rita Kehl (2004), para quem esse sentimento é uma "vingança adiada" que ocupa no ressentido um lugar central em seu discurso e subjetividade. No que se refere à sociedade, a autora defendia que o ressentimento é ultrapassado quando se apresenta "a existência de uma ordem social na qual um direito tenha sido garantido por antecipação a todos" (p. 139).
} 
considerando que o percurso da narrativa aponta para uma superação da problemática.

A proximidade emocional da narradora de Albues em relação ao que descreve e conta de seu passado (o teor autobiográfico do texto) acentua uma tonalidade de intolerância às injustiças sociais e qualquer outro tipo de injustiça percebida, no sentido de atrair e convencer o leitor a dividir consigo as mesmas preocupações. $E$, assim, compartilharem da mesma crítica sobre o passado, no sentido de pensar uma nova realidade. Em algumas passagens de $O$ berro, a narradora trata diretamente de como ela, às vezes, deixa-se contagiar, apesar da distância temporal, pelas emoções diante dos infortúnios vividos pela personagem:

[...] Saltei de banda. Libertei-me. Da ira. Da compulsão da represália. Não da dor. Tenho dó da menina indefesa, tenho ganas de protegê-la, alcançá-la no tempo, amenizar seus infortúnios. [...] Meu coração se contorce, o corpo estremece enquanto escrevo, descrevo sua agonia, não estou imune. [...] A câimbra que entorpece minhas mãos, distorce a caligrafia, desfoca imagens que conservo nítidas? (BCN, p. 162, grifos nossos).

A emoção de que a narradora-personagem é acometida pode levá-la a distorcer a realidade recriada. Nas frases em negrito, a objetividade pretendida pelo eu do discurso é ameaçada pela subjetividade constituída pela presentificação das emoções e dos sentimentos de outrora. Em contrapartida, essa passagem também revela certa transformação no comportamento da adulta narradora ao retomar suas origens através da memória, pois aparecem sinais de sua maturidade nas reflexões ao arriscar uma análise de seu próprio discurso, falando de si mesma.

Em uma outra direção, analisando textos literários que versam sobre o colonialismo e sobre a guerra pela libertação dos países Africanos, Isabel Magalhães ressalta que a infância recriada nas narrativas apresenta-se, muito distintamente da vida adulta, como um momento de plenitude do qual está eternamente separada, isto é, há uma imagem quase que idealizada da infância em oposição a uma imagem negativa da vida adulta:

Apenas a infância parece ter sido para muitas destas figuras o tempo de uma coincidência exata de si consigo mesma e com os lugares; de sintonia de si com a terra, o tempo, as relações sociais e até com Deus. A reconstrução ficcional da infância é freqüente, sendo esta 
mostrada como uma perfeição para sempre perdida. (MAGALHÃES, 2002, p. 316).

E, assim, somente a memória seria capaz de aproximar o sujeito deste "paraíso perdido", a infância. Trata-se, nesse caso, de uma visão otimista do escritor ao tratar da meninice, enfim, do passado de modo geral. Nesse sentido, com base no pensamento de Halbwachs (2004a), há um olhar ilusório do passado, em que o mundo do presente é menos atraente que o mundo de outrora. É como se a distância do tempo pudesse apagar as amarguras vividas, restando, para ser rememorado pelo sujeito, apenas as boas experiências ou mesmo os acontecimentos de sentido negativo que passam a ser reabsorvidos pelo memorialista por meio de outra perspectiva, que, mediada pelo sentimento de saudade da vida que passou ou pelo próprio distanciamento no tempo, permite ao sujeito um olhar afetuoso para os acontecimentos recordados. Nesse sentido, há situações em que o ressentimento e a consternação em relação às experiências passadas, com o tempo, dão lugar à melancolia e ao desejo de retornar ao passado para revivê-lo como um prazer, uma felicidade que ficou para trás. Segundo Halbwachs, a maioria dos escritores que externaram suas impressões sobre o passado da infância, da adolescência e até do início da juventude, sempre se referem aos acontecimentos de outrora e às pessoas, com quem conviviam, com ternura e afeição (Cf. HALBWACHS, 2004a, 130-1).

Em Anarquistas, graças a Deus, de Zelia Gattai, e em O menino de engenho, de José Lins do Rego, por exemplo, essa visão positiva do tempo da infância revelada pelos narradores-personagens que se destaca na obra dá ao discurso em primeira pessoa certa nuança saudosista em relação ao vivido. Mas se observa que nenhuma das protagonistas de Percursos e de $O$ berro rememora a infância como um paraíso perdido, contagiada pelo desejo de um tempo em que, visto à distância e em meio às dificuldades e aos dramas do presente e da vida adulta, fora feliz. Nesse sentido, tendo como base as ponderações de Halbwachs, as duas protagonistas fogem ao habitual, por diferenciarem-se em termos de características do perfil apresentado com frequência pelas personagens de memória que apresenta as experiências da infância a partir de uma linguagem saudosista.

Apesar de apresentarem um texto de importantes traços e valores poéticos, constituídos pelo imaginário da criança, pelo ficcional, a parte da narrativa referente ao tempo da infância dá ênfase à amargura e aos aborrecimentos experimentados 
pelas personagens principais nas duas obras. O que contribui fortemente para que as memórias da infância, retomadas pelas protagonistas de Albues e de Ramos, resultem em um texto de maior fluidez são, em sua maioria, as peculiaridades do olhar da criança que precede e orienta a perspectiva experiente do adulto que narra. Sabe-se que a criança vê o mundo de modo peculiar: a ingenuidade criativa, a simplicidade e o desejo de atrever-se, descobrir o mundo é que caracterizam seu olhar, que ao se fazer presente na voz do narrador, dá uma tonalidade lírica à narrativa. Outro aspecto a salientar, nesse sentido, é que a narradora adulta filtra todas as vozes manifestas no texto de modo a camuflar determinados traços da perspectiva infantil, teimosos em se fazer presentes. Essa voz adulta que filtra as demais vozes presentes na narrativa em $O$ berro se apresenta mais complexa que em Percursos, visto que a voz do narrador em terceira pessoa dessa obra traz em si a voz da personagem adulta a lembrar a infância e, assim, a voz da personagem no tempo de criança é filtrada pelas duas anteriores (a do narrador em terceira pessoa e a da personagem principal adulta).

\subsection{Memória: vozes que se cruzam}

A liquidez, representada pelas águas fluviais acentuadamente presente nos textos, também está anunciada na forma de expressão da personagemnarradora de Albues e da protagonista de Wanda Ramos. As duas personagens, ao pronunciarem seus discursos, tomam, muitas vezes, determinadas marcas e elementos de linguagem dos grupos sociais dos quais participaram durante a vida, no passado e no presente, notadamente, e também dos autores de textos que leram e de filmes a que assistiram e de outros tipos de linguagens por elas decodificadas. Nessa reflexão, a forma liquida da água, difícil de ser contida, pode significar, então, a diluição de fronteiras que separam a abordagem discursiva individual da expressão do coletivo, em que cada personagem está e esteve inserida ao longo da existência. O discurso dessas personagens, a desfiar suas memórias, apresenta-se composto por uma diversidade de componentes representativos da forma de expressão ou do conteúdo da fala ou da escrita de outrem.

Assim, as vozes da protagonista-narradora de Albues e a da protagonista de Wanda Ramos trazem uma infinidade de outras vozes, muitas das 
vezes complexas e impossíveis de serem identificadas e reconhecidas. O olhar que a personagem de Percursos volta para si mesma vem embebido do olhar de "outrem", das outras mulheres que participavam da mesma condição de esposa a fazer companhia ao marido na guerra. Apesar de sua visão dos eventos apresentar elementos essenciais peculiares da visão de sua família portuguesa conservadora, de onde se originou, a protagonista apresenta, enfaticamente, em sua voz, traços peculiares que a aproxima da perspectiva do angolano, marcada pelo sofrimento em decorrência do colonialismo imposto por Portugal. Nesse sentido, percebe-se ainda que o discurso da personagem portuguesa traz, em sua constituição, definidas críticas, discordando da formação que recebeu dos pais. O diálogo com outras pessoas que compunham o meio intelectual de convivência da personagem de Wanda Ramos, juntamente com os textos que, como intelectual, por ventura, ela tenha lido, enfim, o discurso assimilado pela protagonista de Wanda Ramos, de todas as demais pessoas ou grupos de seu convívio atual ou de outrora se fazem presente, de alguma maneira e com intensidades diversas, na composição de seu discurso. Há momentos relevantes em que a protagonista entra em sintonia com a voz dos nativos reunidos em cerimônias:

\begin{abstract}
Horas foram então de espanto muito novo para os olhos dela, e os muquixes, ó pai, aqueles homens vestidos de bichos [...] horas foram, e desde então entraram os muquixes na sua vida para sempre, e ainda hoje, serão por ventura seu privado maravilhoso, mundo que ciosamente guarda. [...] vozes, múltiplas vozes articulando-se soltamente [...] batucada, circuncisão, limiar de machos amadurecendo para procriar [...] ali postos os tundanje do quimbo há meses sem se lavarem, escutando as sensíveis palavras dos iilombola [...] (p. 32-34).
\end{abstract}

Além dos elementos da linguagem dos presentes na narrativa portuguesa, esta também se compõe de passagens escritas em francês e em inglês e de citações de outras obras da literatura inglesa e francesa. Nesse sentido, é interessante destacar, dentre as várias situações de uso da língua francesa, as citações que constituem a epígrafe de Percursos:

J'aime qui respecte son chien, affectione sés outils, n'écorce pas l'arbre pour en punir la sève, ne mouille pas le vin hérité, se moque de l'existence d'un monde exemplaire ${ }^{20}$. (René Char, La nuit talismanique).

\footnotetext{
20 "Eu gosto de quem respeita seu cão, tenha afeto por suas coisas, não corte a árvore para extrair a seiva, não entorne o vinho recebido, que duvide da existência de um mundo perfeito".
} 
Quelle idée prendre de l'humanité et de la religion des partisans de l'intolérance? Ceux qui croient que la violence peut ébranler la foi des autres donnent une opinion bien méprisable de leurs sentiments et de leur propre constance ${ }^{21}$. (Diderot, Encyclopédie).

Com essas duas citações, uma do poeta surrealista francês René Char (19071988), e a outra do filósofo e escritor Denis Diderot (1713-1784), um dos pensadores mais relevantes do lluminismo, o texto de Wanda Ramos já convida o leitor mais preparado a refletir sobre a presença do outro, do diferente, especialmente no uso das palavras de Diderot, ao tratar criticamente da intolerância religiosa. Por meio de uma linguagem figurada, uma espécie de provérbios já conhecidos ou criados por ele, o poeta René Char defende determinados valores morais e éticos que favorecem a valorização do "outro" não só quando este "outro" é um ser humano, mas quando representa outras instâncias da vida na natureza e, de modo geral, ser no mundo.

Em O berro existem sinais reveladores das diversas vozes que compõem o fio narrativo do texto, revelados aos olhos do leitor, muitas vezes, de maneira evidente, como os traços balizadores do falar cuiabano, a exemplo da expressão "quá" ("quá, você não aprende mesmo" - p. 127), das falas do povo simples moradores dos pequenos bairros, povoados e do campo.

Os vários tempos-espaços que demarcam o percurso narrativo de $O$ berro se manifestam também através das expressões, da linguagem, como um todo, usadas no discurso das pessoas de convívio da narradora-personagem. Desse modo, a voz da protagonista adulta do período da narração vai se apresentar permeada por expressões em inglês, as quais demarcam sua presença nos Estados Unidos, onde residia há uma década e meia. Entende-se que o discurso do "outro" também se faz presente nas expressões usadas por ela em inglês e também pelas relações intertextuais da narrativa com outras obras literárias, como por exemplo, a expressão "Severinos internacionais" (p. 137), a qual, além de referir-se à questão da realidade social, econômica e política do homem contemporâneo, alude-se diretamente ao Auto de natal pernambucano Morte e vida severina, escrito por João

\footnotetext{
21 "Que idéia pode ter da humanidade e da religião os partidários da intolerância? Aqueles que acreditam que a violência possa abalar a fé dos outros, dando uma opinião negativa de seus sentimentos e de sua própria perseverança" (Diderot, Encyclopédie).
} 
Cabral de Melo Neto, construindo assim uma rede de significados de relações inter e extra textuais.

A questão das relações interpessoais na constituição de sua voz da narradora-personagem de Albues também conta, e de modo proeminente, com as intertextualidades estabelecidas pela narrativa de forma evidente ou subentendida com outros textos do sistema literário brasileiro, como já observamos em relação à intertextualidade com o texto de João Cabral. Podemos evidenciar outras situações de diálogos do texto de Albues com outros textos em passagens como: "Desprendiase do seu semblante uma expressão ingênua e transparente, tão delicada [...] 'Desculpem o incômodo. Ida. Foi assim que ela viveu. Desculpando-se” (p. 228). Apesar de não apresentar, nessa passagem, nenhuma referência direta ao texto $A$ Hora da Estrela, de Clarice Lispector, a forma como a narradora de Albues define a personagem lda lhe confere um contorno muito próximo do perfil apresentado pela personagem do referido romance, Macabéa, principalmente a personagem recriada pela linguagem cinematográfica, em adaptação ${ }^{22}$ homônima do cinema para o romance, lançado em 1985. Diversos momentos de $O$ berro que delineiam, de modo evidente ou sugestivos, abordagens intertextuais com diversas produções literárias, cinematográficas, demais produções artísticas e pensamentos do mundo contemporâneo revelam que a voz da protagonista-narradora está conectada a um emaranhado amplo de outras vozes, de outras pessoas ou de personagens de origens e naturezas diversas. A escrita e a oralidade, por meio da rememoração e de outras formas de linguagem, permitem à personagem estar em sintonia com as vozes não só de seu tempo e espaço, mas também de outras circunstâncias e eventos fora de seu contato direto.

Muitas vozes se cruzaram com o discurso da protagonista de Wanda Ramos por estarem todas inseridas no contexto histórico, social e político de Portugal e de suas colônias ou ex-colonias e por serem proferidas por personagens de outros textos, centrados em temas similares aos versados em Percursos. Nesse sentido, podem ser mencionados, como exemplo, os romances As Costas dos Murmúrios (1988), de Lidia Jorge, $A$ árvore das palavras, de Teolinda Gersão, e Corpo Colonial, de Juana Ruas (1981). São obras que abordam, por meio de seus

\footnotetext{
${ }^{22}$ A hora da estrela é um filme brasileiro, de 1985, uma adaptação do romance homônimo de Clarice Lispector, sob a direção de Suzana Amaral.
} 
personagens principais, questões referentes às mulheres portuguesas que viveram uma situação, de certa forma, longa de trânsito entre Portugal e suas colônias e construíram, a partir do seu lugar de pertença, um olhar sobre o colonialismo português e a Guerra Colonial.

Neste trabalho, a visão da multiplicidade de vozes a constituir a narrativa romanesca e/ou autobiográfica ajusta-se à ideia do dialogismo de Bakhtin e à ideia da memória como um elemento coletivo, e não apenas fruto das observações individuais, como argumenta Halbwachs. Quando a autora Wanda Ramos usa a significativa expressão "rios estes de áfrica que ainda lhe ensopam a memória" (p. 69), atrai a atenção do leitor para o sentido coletivo subjacente ao ato de rememoração. Ao apreender o passado e ao interpretar suas lembranças, o sujeito o faz a partir de um olhar e de uma linguagem constituídos e desenvolvidos com a participação de inúmeras pessoas, que, de forma direta ou indireta, tenham feito parte da história desse sujeito.

Como o sujeito não pode proferir um discurso e um olhar como unicamente seu, considerando que os mesmos são constituídos a partir de traços oriundos de muitos outros discursos e olhares, a memória também não pode ser constituída a partir de um único indivíduo vivendo em isolamento. A construção da memória tem por base referencial o sujeito - cujas percepções, de acordo com o discurso de Halbwachs, (2004, p. 78 e 81), estão filiadas à memória dos outros, de um grupo, de um coletivo - e o sujeito é um contínuo vir a ser, sua identidade vai sendo consubstanciada - na visão bakhtiniana - por meio das relações estabelecidas com os outros de modo dialógico.

Nas narrativas de Percursos e de O berro, deparamos nos textos com diversas "pegadas" do diálogo estabelecido com outras produções textuais, literárias ou não, e de outras formas de arte, que se configuram como componentes da tradição literária e cultural ocidental. Esses vestígios de outras produções, encontrados em ambas as narrativas, aparecem ora claramente definidos, ora subtendidos às manifestações discursivas. Como já foi observado no primeiro capítulo deste trabalho, para Benjamin (1994, p.211), a reminiscência institui todos os elos da tradição, que vão se entrelaçando de geração em geração. Pode-se então entender que é ela que tece as relações intertextuais estabelecidas pelas produções literárias, artísticas ou demais produções em qualquer forma de linguagem. Assim, é a reminiscência que instaura a rede de ligações constitutivas 
entre o "eu" e o "outro", por isso, ela está intimamente ligada às questões da linguagem. A memória é um elemento indissociável da linguagem e tanto aquela como esta levam em consideração, na sua gênese, a presença do "outro", contida na percepção de que o "eu" constrói a realidade de si e daquilo que deve ser esquecido ou lembrado.

Nesse sentido, o conhecimento de Bakhtin nos possibilita entender a acepção de Halbwachs sobre a memória, na medida em que a visão bakhtiniana, além de trazer a questão das várias vozes que se organizam na tessitura do discurso, também antecipa uma relação dialógica do sujeito, do discurso com o seu receptor/leitor. Ao narrar suas lembranças, o sujeito não só o faz conforme a participação de todos os grupos que tenham feito parte de sua vida, mas também leva em consideração a perspectiva daquele que ouve ou lê seu texto. Para atuar no presente, o passado depende da memória, que é um ato essencialmente coletivo, pois, ao lembrar-se do que aconteceu no passado, o sujeito o faz conforme suas relações interpessoais e, além do mais, para se constituir enquanto texto, o conteúdo lembrado necessita da linguagem, um elemento essencial da cultura humana criado e desenvolvido no meio coletivo.

No caso da protagonista de Percursos, esta é orientada pelos pais e pelo processo social do colonizador a aniquilar e a ignorar tudo que aprendera da realidade do colonizado. Assim, a língua, as narrativas, as experiências do colonizado sorvidas pela protagonista deveriam ser esquecidas conforme a ideologia do poder dominante. Mas, para o desconforto do colonizador, a formação identitária do filho do português em África, em muitos casos, contraria os interesses da Metrópole, por este deixar-se envolver pela cultura, pela linguagem e pelo estilo de vida estabelecido pelo povo local, pelo outro. E é essa mescla de elementos da cultura e da tradição angolana, com o conhecimento e a cultura conservadora da metrópole, que vai permitir que a personagem de Wanda Ramos, mesmo sendo filha de pais portugueses, efetue uma leitura diferenciada do mundo à sua volta, fugindo aos controles da moral e do poder político vigente. Como já foi observado em outros momentos deste estudo, por meio da abordagem halbwachsiana, a memória pessoal é componente de um todo social, no qual o sujeito falante está inserido, mas que o antecede. Em síntese, o ato de lembrar é conduzido pelo convivo intersubjetivo da personagem de Percursos em Angola e em Portugal e da 
personagem de $O$ berro em Mato Grosso, no Rio de Janeiro, nos Estados Unidos e em outros lugares por onde tenha viajado.

Tendo como base ainda o estudo de Bakhtin sobre a questão do cronotopo, é preciso considerar que os espaços referidos pela memória do sujeito vêm carregados dos indícios temporais, pois, cada evento lembrado, além do apoio da memória daqueles que tenham de alguma forma participado de vida de quem rememora, inclui como pano de fundo um contexto social, histórico e filosófico. A individualidade e a subjetividade, portanto, estão inseridas num todo maior, no contexto social e histórico. Para lembrar, o sujeito depende da participação dos outros, das pessoas que o despertem para uma ou outra lembrança; são as outras pessoas que vão interferir na interpretação que a pessoa tem do passado, no sentido de confirmar ou negar as afirmações que, por ventura, sejam realizadas. $O$ ato de lembrar não é então um ato individualizado, está impregnado das relações interpessoais travadas pelo "eu" com os "outros" dentro das várias instituições sociais como a família, a igreja, a escola, etc. O individual no campo das memórias e da linguagem emerge a partir do entretecer dos vários pensamentos, culturas e lembranças de um coletivo. Sabe-se que o ser humano só conseguirá objetivar e externar suas recordações mediante a linguagem, que já é uma construção coletiva, como a cultura, preexistente ao sujeito. Assim, a individualidade se constitui a partir do confrontar das experiências comuns e genéricas com o percurso de vida, que é exclusivo para cada pessoa.

Elizabeth dos Santos Braga (2000), em seu texto "O trabalho com a literatura: Memória e histórias" ressalta que "no ato de narrar, os fatos passados matizam-se, o sujeito se dobra sobre a própria vida. Somos levados a pensar em como, pela narração de nossas lembranças, vamos nos tornando sujeitos e nos inscrevendo na história" (p.88). Em um determinado momento da narrativa, a narradora de Albues trata dessa questão, refletindo sobre o que lhe ocorrera enquanto personagem da narrativa:

Será que foi este sentimento que me fez manter a calma quando uma noite no sala-e-quarto da Praia do Flamengo, eu me vi, de repente, com os minutos contados de vida? Pode ter sido também por desespero. O terror quando é demais ultrapassa o imaginável, daí pra frente a ação é automática, o racional se anula, é só intuição comandando o que não tem mais comando. Fico eu agora, no conforto do meu estúdio em Nova York, tentando analisar uma 
perigosa situação espremida entre a kitchnette e a mesa de jantar, entre o medo e a salvação improvável. (p. 166-167, grifos nossos).

Por intermédio do primeiro, segundo e terceiro períodos da citação, a narradora tece um comentário crítico sobre um acontecimento narrado pertencente a um passado longínquo, a partir de sua perspectiva no presente da narração. No quarto e último período ela tece uma autoanálise, observando a si mesma. Nesse último período, a narradora demonstra a consciência que tem do seu distanciamento estabelecido em relação ao conteúdo narrado e ainda lamenta a impossibilidade de agora, no tempo da narração, conseguir se colocar no lugar da personagem que foi (tempo da narrativa), sendo quem é, de onde narra e emite seu olhar sobre a experiência contada. $O$ distanciamento que separa aquela que conta daquela que vive os acontecimentos permite, de forma proeminente, a intercessão da voz do coletivo com a voz da narradora, de modo que a rememoração do "eu" se consubstancie com a participação ativa do discurso e da memória de "outrem" na narrativa de maneira crescente, cada vez mais que a distância entre o sujeito que narra e o evento lembrado se prolonga.

Além das várias vozes que se interpenetram na construção do discurso da narradora, há o encontro da personagem com pessoas falantes através línguas diferentes, oriundas das mais distantes áreas do planeta:

E no altar do Rockfeller ecoam as vozes de todas as raças de
peregrinos que vêm do mundo inteiro visitar a Big Apple. As línguas
se misturam, gargalhadas, cânticos, flashs, flags, patins, filmadoras,
clarinetas, odores, louvores de todas as nacionalidades, credos,
cores. A confusão é total, agora é minha vez de dizer "disgusting",
não tenho nada com os tremores ou temores alhures despertados,
recolho meu berro inocente, trago-o de volta à tapera do Cristazal,
recomeço aumentando o volume de minha dor. (p. 94).

Tereza Albues, ao tratar, em $O$ berro, de suas memórias e da realidade conturbada da cidade de Nova York o faz de maneira equivalente ao processo de rememoração, em que os acontecimentos aparecem na consciência como um turbilhão, numa ordem que foge ao racional cronológico das narrativas tradicionais, para seguir os caminhos delineados pelas sensações e sentimentos vivenciados pela personagem-narradora que lembra suas experiências do passado. A consciência da protagonista-narradora se assemelha à realidade tumultuada de Nova York, pois a "confusão total" é uma expressão que pode qualificar tanto aquilo que é possível na grande megalópole repleta de peregrinos vindos dos mais remotos 
lugares do mundo quanto a consciência da protagonista povoada por inúmeros e contraditórios eventos lembrados. Esses dois turbilhões (o de Nova York e o da consciência da memorialista) ainda encontram equivalência no tumulto de sentimentos vivenciado pela personagem na infância marcada pela inconstância, pela pobreza e especialmente pela loucura do pai. E aí, novamente, o grito enquanto expressão simbólica é ressaltado na narrativa. O seu grito de menina pelos seus direitos a estudar se junta, por meio da memória, às vozes de todas as etnias de peregrinos em Nova York: "recolho meu berro inocente, trago-o de volta à tapera do Cristazal [...]" (p. 93). Aconselha o pai à menina insatisfeita com o destino que lhe vai sendo delineado: "grite enquanto tiver vontade, não deixe nem um restinho de dor ficar morando dentro de você em silêncio [...]" (p.).

Ao versar sobre a diversidade de manifestações discursivas em que ocorre a relação da voz do "eu" com a voz de "outrem", é importante tratar de uma complexa forma de estruturar o foco narrativo em um texto de memória ou ficcional, que é o fluxo da consciência muito frequente na narrativa de $O$ berro como se observa nesta passagem:

E a cantoria segue no sertão enluarado, no coração desta mulher rodeada de arranha-céus em Manhattan, a ilha que não é Mikonos, a ilha que também me cerca encantamento. Pelo rio Hudson as folhas secas, aguapés, cipós brancos, que desembocam no meu riacho do Cordeiro, espremido entre pedras, arvoredos, touceiras de bananeira brava. Deslizam. Da Fazenda Quirinal a Nova York eu nem ouso falar que o caminho é longo, Princesa Frederica Marialva ficaria espantada, eu também, é o "Longe Daqui Aqui Mesmo" de Antonio Bivar acontecendo no rio de janeiro, nas praias descalças de Santo Antonio do Leverger, na Grécia em Nova York, reminiscências não, acontecências superpostas, longitudinais, dos antanhos, do agora iluminado pelo cravo vermelho lançado na corredeira vertiginosa do Véu de Noiva, vira arco-íris, irmana-se às piçarras, festas maior pra quê? (p. 180).

Essa passagem traz imagens de um passado distante, por isso, pertencentes ao um espaço (Mato Grosso da infância da narradora) também longínquo, que se sobrepõe a uma imagem atual, isto é, próxima ao tempo da narração. Há, nessa passagem, forte relação metafórica e simbólica com a água e o rio, como já referido nas páginas iniciais deste capítulo. Num contraste bem definido, o riacho do passado, de outro espaço geográfico e cultural (do Cordeiro), é capaz de desaguar no grande e histórico rio de Nova York, em sentido figurado, elementos oriundos da 
natureza mato-grossense, vivenciados na infância pela personagem, "as folhas secas, aguapés, cipós brancos". Estes podem ser caracterizados como as inutilidades do mundo pós-moderno, assinalado pelas peculiaridades do universo urbano próprio de uma megalópole como Nova York. Essas inutilidades que são levadas à superfície pelas correntezas do imponente rio representam a própria memória da protagonista-narradora a viver no momento presente da rememoração num espaço e tempo tão contrastantes com o que vivenciou no passado. No processo de rememoração, os elementos do passado, por mais que sejam destoantes do momento atual, definidos na narrativa - representados pelo significado metafórico do rio Hudson - por serem representantes da memória, são conduzidos pelo presente. Assim, ao tratar da memória, observa-se que as lembranças do passado são norteadas e construídas conforme o presente do sujeito que recorda, considerando que a identidade deste é constituída e transformada pelas relações sociais estabelecidas por ele nos diversos grupos dos quais fizera parte nos diferentes momentos de sua existência.

Nas últimas linhas da citação acima, salta aos olhos do leitor um turbilhão de acontecimentos misturados e confundidos, em que o tempo e o espaço são abolidos, como o que ocorre na mente da narradora-protagonista "viandante", ao atentar para suas lembranças. Essa mistura também tem relação de sentido com o perfil da personagem em constante transitar, que representa a existência do homem atual que pode, em um curto espaço de tempo, perambular por vários lugares do planeta.

Analisando diversas passagens do texto de Albues, entende-se que passado e presente convivem e coexistem na mente do sujeito a recordar. Inúmeras percepções, lembranças e impressões do passado vêm à tona, em ebulição, na consciência daquele que lembra ou imagina, o que se dá em consonância com as percepções e sensações do presente. Narrados e descritos na forma caótica, como jorra o pensamentos e as lembranças nos processos mentais, obtém-se como resultado o fluxo da consciência, que, em O berro, além de constituir o complexo de estruturação da narrativa, está representado denotativamente pela metáfora da corrente das águas do rio Hudson, o qual compõe o espaço e ambiente do tempo da narração do texto. Dessa maneira, o fluxo da consciência simula, então, o funcionamento da mente, que se opõe à linearidade cronológica das narrativas tradicionais, em que os eventos narrados são delineados ao sabor da razão. 
O fluxo mental de pensamentos, representado na escrita literária pelo fluxo da consciência, é contínuo e caótico, de maneira que determinadas fronteiras que delimitavam ou situavam o discurso narrativo tradicional deixa de existir como o tempo e o espaço. Diante dessa realidade posta pelo texto, é possível fundir, ao situar os acontecimentos, o espaço mato-grossense com Nova York, o tempo da infância da personagem com o tempo da vida adulta. Essa fusão, impossível de acontecer no terreno de domínio da lógica, dá a ideia de ausência, ou seja, nessa constatação, não há tempo, não há espaço. Isso se aproxima do que hoje poderia constituir um dos paradigmas da atualidade, em que com o desenvolvimento da tecnologia e da informática há o fim do espaço, do tempo e também da massa.

Na reflexão proposta neste trabalho, cujo foco principal é a rememoração efetuada pelas personagens de suas experiências, é de grande relevância que se atente para a forma como cada uma das duas narrativas apresenta diversas manifestações discursivas que se interpenetram, se fundem na constituição do discurso, muitas vezes, aparentemente único e impermeável do enunciado. Tanto em berro quanto em Percursos percebe-se uma presença significativa do discurso indireto livre, ou seja, a incorporação pelo enunciador da voz de "outrem", que se efetua de maneira não objetiva, pois não há muita distinção nítida entre as vozes que se manifestam no diálogo.

Na maior parte da narrativa de Wanda Ramos, não há indicadores expressos que definam o discurso alheio, como: o verbo introdutor, os dois pontos, o travessão e as aspas usados no discurso direto; a conjunção componente e o verbo introdutor no discurso indireto. É o que se observa em muitas passagens como esta. Veja esses conectivos:

[...] tudo por entre o espiolhanço raivoso das mulheres do sargentos que corriam a contar aos maridos em que orgias pecaminosas alinhavam o médico e a mulher, na promiscuidade dos furriéis e cabos convidados para a patuscada e dos camionistas que, despudoradamente, fornicavam debaixo das camionetas as putas mais finas que traziam em excursão do Luso [...] (p. 71).

A voz do narrador em terceira pessoa, cujos traços já acusam a presença da voz da protagonista ora adulta, ora criança, aparece mesclada pelas vozes das mulheres a ocuparem-se da vida alheia, inclusive da vida da protagonista e de seu marido. É relevante acentuar que nessa intersecção de vozes, por intermédio do 
processo de rememoração, vários cronotopos também se confundem como o espaço-tempo dos diversos acontecimentos e o espaço-tempo da narração.

Há, ainda, outra forma frequentemente utilizada pelo narrador de escrever e citar o discurso de "outrem" em Percursos, fora dos padrões estabelecidos da linguagem escrita: apesar da omissão de certas marcas fundamentais do discurso direto, como a falta do enunciado das falas das personagens, efetuado pelo narrador em terceira pessoa; do travessão ou das aspas, distinguindo as falas das personagens a dialogarem, o que se observa nesta passagem a seguir é a existência de um diálogo definido pelo discurso direto sem as devidas pontuações: "Vai 'gora no mato, sinhora. Seu matumbo, vai no mato fazer o quê? Vai ver família, mulher lá, no mussôco. Tem ainda os menino, tirar saudade dele. Vai mas vem logo, tem o serviço pra fazer, tem hoje visita" (p. 11). O tempo e a pessoa dos verbos, juntamente com a linguagem e o vocabulário próprios da oralidade e das personagens envolvidas, são sinais que definem a existência de um diálogo entre o criado negro e sua senhora (a mãe da protagonista). Graças a esse distanciamento dos padrões convencionais de elaboração do discurso, juntamente com a presença de lacunas no percurso narrativo e quebra na ordem habitual de abordagem dos acontecimentos, fica embaraçoso para o leitor discernir, de imediato, a maneira como estão estruturadas as diversas manifestações das vozes no texto. Assim, muitas passagens da narrativa de Percursos, de acordo com a definição do gênero do discurso, situam-se em um entre-lugar, por não se encaixarem nem no discurso direto, nem no indireto e nem no discurso direto-livre, considerando que não apresenta as características especificas de nem um deles. Assim, a diluição da fronteira que delimita as diferentes vozes no discurso nos dá a ideia de que está subjacente ao texto a intenção de salientar a mistura de falas, o que acentua a natureza subjetiva do texto, tendo em vista que é do leitor uma grande parcela da responsabilidade de estabelecer os limites definidores das vozes manifestas em cada circunstância textual. Tem-se, então, uma hibridez discursiva que se faz presente em toda a narrativa. Um exemplo dessa situação analisada aparece constituído na seguinte passagem de Percursos:

ó pai o que é aquilo, ó mãe olha ali, aquele barco tem criados e tudo, como o João Joelho lá do Dundo, e aquele senhor de boné branco com dourados nos ombros, ó filha aquele é o comandante do navio, comandante, o que é comandante? Um senhor que comanda, definia Icónica e dicionaristicamente o pai, há, e nessas férias o vocabulário 
dela aumentou grandemente, andou até numa escola que não era da Companhia [...] (p. 34).

Tanto a voz da protagonista, que se confunde com a do narrador, quanto essas duas aparecem misturadas às de outros personagens, não só através da estratégia do discurso indireto-livre, mas também pela falta de sinais de pontuação e outros elementos peculiares do diálogo direto. Misturadas as falas do narrador e da protagonista, já confundidas entre si, confundem-se com a voz de outros personagens, o que representa o expressivo coro emitido por toda uma coletividade, condizente com a sociedade em que a obra está inserida.

Por averiguarmos que o hibridismo predomina na composição discursiva da narrativa quanto às manifestações pessoais, é de relevância reportarmo-nos novamente à Bakhtin, para quem o discurso indireto-livre dilui os limites entre as diversas vozes que se fundem. Sendo assim, o discurso indireto-livre é a forma mais apurada de "enfraquecimento das fronteiras do discurso citado" (1986, p.152).

Em $O$ berro, o leitor depara-se com diversas passagens em que 0 discurso indireto livre se faz presente, como no exemplo da passagem a seguir:

Naquela noite o medo dormiu com a gente, o silêncio lá fora não dava garantia de que o perigo havia passado. Onça é treteira, animal esperto e traiçoeiro, que vai se fiar? Já vi muito caçador ser tocaiado quando pensava ter ferido ela de morte, dizia papai nas conversas com outros homens, eles apoiando, balançado a cabeça, atiçando a fogueira com gravetos. Mas a fera não voltou, sumiu na arca do mundo, graças a Deus, disse mamãe. (p. 15, grifos nossos).

A ausência de aspas e de travessão não é suficiente para enquadrar essa passagem do texto como discurso indireto; o verbo na primeira pessoa e 0 enunciado em terceira pessoa, definindo a fala do pai e da mãe da protagonista narradora, dão ao texto uma nuança de discurso direto. Na verdade, de modo semelhante ao que ocorre no texto de Wanda Ramos, o texto de Tereza Albues, em especial, neste momento da narrativa, termina por sugerir uma junção da voz da protagonista-narradora, do tempo da narração, com a expressão de seu pai ou de sua mãe de outrora, no tempo e espaço que constituem o cronotopo referente ao mundo da infância da personagem. É importante observar ainda que, ao rememorar, a narradora arrasta, junto da sua voz, não só a do pai, mas também a voz de um povo simples de que seu progenitor fez parte e, de certa maneira, ela também. A narradora, na sua individualidade, carrega consigo a voz de um coletivo, de que fez parte no passado. 
E a expressão de sentido cosmológico e mítico, "sumiu na arca do mundo", da citação anterior, colocada pela narradora na boca da mãe, apresenta um referencial de sentido mais condizente com o perfil discursivo de Benjamim Barbudo ou com o da própria narradora, pois esta se caracteriza como uma mulher adulta de pensamentos místicos que se espelha nos argumentos de Benjamim, conforme ela mesma diz, ele se constituiu como mestre da sua vida. Essa ideia é reforçada pela referência logo no parágrafo seguinte, no parágrafo referente à personagem Benjamim Barbudo e também pelo fato de que essa personagem aparece na narrativa sempre aliada à carga significativa expressa pela palavra "mundo": "Vivia pelas estradas, não tinha paradeiro, dizia que sua missão era correr mundo [...] anda pelo mundo, tem muito pra contar" (BCN, p. 16).

$O$ discurso indireto livre comunga, então, com muitos outros elementos formais do discurso, que diluem a fronteira entre o discurso do "eu" e o discurso do "outro". Ao manifestar uma voz híbrida da voz dos outros personagens ou de um coletivo, implícito no texto, traz à tona a ideia de que o sujeito que fala tem, em sua essência constitutiva, a presença do "outro" na sua diversidade. Nesse sentido, a narradora-protagonista de Albues dá concretude àquilo que conta, levando o leitor a se aproximar cronotopicamente daquilo que lê e identificar-se com a personagem principal em suas acepções e experiências vividas. E por permitir que outras falas permeiem a voz de quem narra, o discurso indireto livre é uma estratégia discursiva que se aproxima do fluxo de consciência, mas que não deve ser confundido com o mesmo. 


\section{CAÍTULO III}

\section{3. ÁGUAS E MEMÓRIAS DIVERSAS}

"Hoje eu lembro dos meus rios

Em mim mesma mergulhada

Águas que movem moinhos

Nunca são águas passadas

Eu sou memória das águas

Eu sou memória das águas”

(Roberto Mendes/Jorge Portugal)

\subsection{Rios: um eterno movimento}

O principal termo do título da obra de Wanda Ramos, Percursos, pode referir-se diretamente ao movimento das águas no leito dos rios em uma determinada distância, num tempo contínuo e indefinido. Já quando se atenta para o que está dito entre parênteses ("Do Luachimo ao Luena"), nota-se que o referido percurso está delimitado pelos rios. Não se trata literalmente do curso das águas, e sim do transladar da personagem nesse espaço entre-rios.

Em toda a tradição literária, bem como ao longo da tradição cultural do ocidente, a imagem do rio apresenta um valor simbólico e metafórico significativo. A presença expressiva do rio enquanto um elemento a transbordar de sentidos aparece em muitas obras da tradição artístico-literária e, de modo geral, em toda a tradição cultural, de forma que, em cada situação, o rio ganha um enfoque em 
consonância com a abordagem temática do texto, como ocorre em Os rios profundos, do peruano José Maria Arguedas, no romance Grande sertão: veredas e no conto "A terceira margem do rio", ambos de Guimarães Rosa, nos poemas que tratam da temática do social por João Cabral de Melo Neto, Morte e vida Severina, 0 rio e Cão sem plumas e, para fechar essa ilustração, o álbuns de músicas da cantora Maria Bethania, Piratas. Dentre as músicas que o compõem podem ser destacadas "O tempo e o rio" e "Memória das águas", a fonte de onde veio a epígrafe deste capítulo.

Para esclarecer esta abordagem referente ao rio enquanto elemento carregado de sentidos a compor substancialmente as narrativas em estudos, é importante destacar, nas obras em estudo, as seguintes passagens da narrativa de Tereza Albues e de Wanda Ramos:

Do Cordeiro a Nova York, é longo o caminho das águas, pontes, barcos, trens, freeways, aviões, montanhas de neve, estações de esquis [...] (BCN, p. 52-53).

De novo as águas turvas do pantanal invadindo meus sonhos, alagando nossa vida, ameaçando levar para longe a tranqüilidade que sonhávamos duradoura. Eu sentia a aproximação da enchente, nada podia fazer pra segurar a força das águas, papai cada vez mais estranho $[\ldots](B C N$, p. 90).

Desde sempre soletrou baixinho esse nome, luachimo, até quando regressada e encaixada na grande cidade, evocação das horas mornas de recordar ou revisitar passados progressivamente impunes, também eles mitificados, como mais tarde havia de soletrar Iuena, rio onde, dizia-se, havia de tornar alguém que uma vez só lhe conhecesse as águas... ( $P$, p. 67-68, grifos nossos).

Nas duas narrativas, o movimento, a transformação são seus componentes essenciais, visualizados simbólica e metaforicamente, em sua grande maioria, a partir das águas dos rios a fluir. Sabe-se que o movimento das águas do rio é capaz de revolver o que se encontra alojado nas profundezas dos leitos dos rios. Nesses termos, o movimento das águas, em sua profundidade, constitui uma metáfora do processo de rememoração, especialmente no caso da memória involuntária, em que determinadas sensações e situações experimentadas pelo sujeito despertam-no, independentemente de seu desejo, para determinadas lembranças de fatos vividos. Estes podem estar associados, inconscientemente ou não, sabor, efeito musical, imagem, textura ou mesmo uma situação, muitas vezes impossíveis de serem evocados intencionalmente, isto é, pela memória voluntária. $\mathrm{O}$ 
passado revolvido através das recordações, muito bem definido pela relação de significado com o fluxo das águas, é capaz de incidir sobre o presente e intervir, de forma decisiva, na constituição dos acontecimentos futuros. No entanto, a memória que, em sentido habitual, estaria para reforçar a ideia de estabilidade e de cristalização da existência do indivíduo ou de um povo - conduzindo o sujeito a voltar seus olhos para o passado e prosseguir a vida a partir dos princípios da tradição e padrões estabelecidos -, apresenta-se na contramão dessa acepção em sentido comum. No caso das duas narrativas focalizadas ao longo deste trabalho a memória promove a ação para a transformação da existência, fazendo do sujeito um novo ser a cada instante. $\mathrm{O}$ ato de rememorar o passado, ainda que impulsionado pelo imaginário, oferece meios para que o sujeito repense as condições de vida estabelecidas no presente e busque transformá-las no futuro. Assim, a imagem do rio, que pode denotar o ato de narrar, as lembranças e todo tipo de percepção que a personagem de Percursos tem do mesmo, apontam para o nascimento de uma nova realidade político-social.

Diante da penosa realidade cingida por "arame farpado", marcada pela fome e pela miséria, somente o rio era capaz de oferecer uma trégua, aliviar a angústia da protagonista de Wanda Ramos. As sensações dessa personagem, seu estado de espírito, são atingidos pela aridez do cenário que a circunda, o qual está em sintonia com a hostilidade do ambiente constituído pelo evento da Guerra Colonial e mesmo pelo colonialismo: "[...] a guerra colonial era realidade pardacenta [...]" (P. p. 45). Os vários aspectos delineadores do rio o tornam destoante da natureza dos acontecimentos em "terra firme", marcados pelo sofrimento e pela violência: "Somente o rio era fresco e vivo correndo pouco profundo nas proximidades, ribas suaves e verdejantes [...]" (p. 68). Somente o rio - esta metáfora do tempo, da memória, do fluxo narrativo, do próprio homem - é capaz de aliviar a fadiga e a alma da personagem e apontar para uma possível trégua dos infortúnios constituídos pelo mundo intolerável e pelos eventos difíceis abordados na narrativa: "E dias de arame farpado continuaram a ser, quotidianamente vividos como farpas dentro do próprio arame farpado. Fora dele os banhos regulares no rio a uma escassa centena de metros, empresa quase arriscada, menos pelo prazer da água [...]" (p. 60-1). Em sentido denotativo, a água a refrescar o corpo e a pele da personagem se sobrepõe às possíveis feridas da sua carne, lanhada pelas farpas 
símbolos da guerra e de todo o contexto da época em que essa narrativa está ancorada.

O "arame farpado", pela cadeia semântica que apresenta, opõe-se ao complexo e amplo significado da presença dos rios, na medida em que o arame, com suas farpas, estabelece limites à liberdade dos homens, podendo cravar suas farpas naqueles que ousarem ultrapassá-lo. Sabe-se, então, que o "arame farpado" simboliza o corte da liberdade experimentada pelo sujeito, os obstáculos impostos a ele em momentos de intensa aflição e angústia, como acontece no período da guerra: "o aquartelamento misérrimo logo à beira, cingindo-o o arame farpado onde se dependurava a petizada à hora do comer à espera dos restos rançosos nos pratos de alumínio [...]" (p. 68).

A imagem significativa da narrativa de $O$ berro que corresponderia à do "arame farpado" em Percursos, enquanto representação simbólica do "mal”, seria a imagem do "visgo", já tratada no capítulo anterior, enfaticamente definida pela personagem Frederica, uma louca por quem a protagonista mato-grossense tem grande afeição:

Lá estão eles naquela morrinheira de fazer dó, presos ao solo visguento como plantas rasteiras que só vingam na superfície, me apontava-os do outro lado. É preciso muito cuidado pra não ficar grudado também, o visgo tem força, amolece a determinação da gente, a tendência é ceder (BCN, p. 219).

Vale lembrar que na visão de Bachelard (1997) o visgo tanto pode ser iluminado sob uma perspectiva positiva quanto negativa. A partir do raciocínio do referido filósofo, quando a água penetra na terra revolvida pelo homem, quando esta se ensopa daquela, pode-se obter uma experiência de "ligação". A água é apreciada pelo seu princípio de viscosidade quando misturada a determinadas substâncias sólidas, como a própria terra, permitindo ao sujeito manipulá-la, dando formas e materialidade a seu imaginário, o qual anda de mãos dadas com sua memória, com sua interpretação das experiências passadas. Um exemplo esclarecedor desse evento seria a figura do "oleiro", de Walter Benjamin, que deixa em sua criação as marcas de suas mãos: "se imprime na narrativa a marca do narrador, como a mão do oleiro na argila do vaso" (1994, p. 205) Sabe-se que qualquer arte construída através da mistura da água com a argila se dá graças à propriedade viscosa dessa 
mistura. Por imagens como esta que a "água é tão amada por sua viscosidade", pois a "experiência do viscoso reúne imagens orgânicas numerosas" que "ocupam incessantemente o trabalhador em sua longa paciência de amassadura" (BACHELARD, 1997, p. 109). Nesse sentido, a viscosidade pode estar ligada ao poder fecundo do muco, cuja imagem pode remeter-nos à origem universal da vida. Em contrapartida, a viscosidade pode apresentar um potencial paralisante ou aniquilador, isto é, contrário ao sentido anterior, pois, como afirma Bachelard, pode provocar a "fadiga onírica" (ibidem, p.110), impedindo os sonhos de se tornarem realidade. Pelo que se observa na citação acima, relacionada à afirmação da personagem-narradora de Albues, é ao viscoso, constantemente, responsável pela imobilidade do ser, árido de invenção, que ela se refere. A textura viscosa da massa paralisa o ser, impedindo-o que desfrute de sua faculdade de criar e transformar positivamente o mundo à sua volta. Em vez de manusear a massa viscosa, explorando a sua capacidade de ser moldada, e construir, o sujeito é aprisionado por ela, o que, metaforicamente, não permite seu desprendimento onírico. Assim, a narradora utiliza da imagem da viscosidade a limitar o ser para interpretar a relação estabelecida pelo sujeito com o seu meio social e político, em que o poder dominante aniquila e impede o ser humano de sonhar, de agir e de conduzir com desprendimento seu percurso de vida.

Apesar do "arame farpado", em Percursos, ser uma metáfora que mais corresponderia à acepção e à intensidade significativa do termo "visgo", usado em $O$ berro, para tratar da dificuldade do ser humano em romper com o pré-estabelecido, superar as amarras do poder ideológico e político, Wanda Ramos também lança mão do adjetivo "viscosos" para qualificar pejorativamente a atuação do corpo docente que avaliou a protagonista de Percursos no exame de admissão:

[...] começara nesse dia o terrível suplício das orais, os anos a correrem e sempre assim, sentada minúscula na carteira e diante dela a massa informe dos professores escorrendo sobre a grande mesa e trocistas, casquinando uns com os outros e para ela feita acanhada nas suas omissões e esquecimentos, para ali armadados em omnipotentes, tão viscosos em seu papel de julgadores... (p. 24, grifos nossos).

Essa passagem de Percursos apresenta uma imagem muito expressiva, no sentido de tratar com relevância a maneira opressiva com que os professores, na sua 
onipotência, alinhada a uma educação retrógrada, desconectada da realidade, em sintonia com o poder ideológico e político vigente, colocavam-se diante da pequenez do aluno a esmagarem-Ihe qualquer capacidade de raciocínio e de autoconfiança, num momento de tensão decisivo da vida acadêmica desses alunos, em que a fragilidade se faz proeminente. É a partir de eventos como esse, lembrados à distância no tempo pela protagonista que a leva a constituir uma postura crítica avessa ao modelo social e político em vigor. A textura pegajosa da massa visguenta pode referir-se à resistência, por parte dos professores, às mudanças, a ganhar espaço em outros mundos fora dos mandos do colonialismo português naquele período, conduzido pela ditadura salazarista.

A plasticidade apresentada pela imagem da "massa informe" do "visgo" (da citação anterior) poderia tratar do flexível, da mobilidade, do receptivo às novas formas do ser, mas não, trata-se de uma imagem criada para falar da arrogância, da postura que engessa a mobilidade das pessoas no seu dia-a-dia. A protagonista de Percursos analisa a postura dos professores que se ocuparam da seleção dos alunos no exame de admissão, os quais agiam em conformidade com o aparato ideológico da ditadura salazarista, mantenedora do império português às custas da vida e da liberdade das pessoas. Mesmo morando em Angola, a protagonista não se depara com uma rede de ensino que aborda as questões locais ligadas à sua existência, que trata do seu mundo. Todo o conteúdo ministrado gira em torno de um espaço e uma realidade da metrópole, um mundo alheio ao referencial da aprendiz em termos de experiência. Há, assim, um silêncio e um vácuo no conteúdo apresentado pela escola no que tange aos elementos presentes no cotidiano da protagonista em sua infância. O que ela aprendia através dos livros era uma "geografia de um continente longínquo [...]" (p.12).

Desse modo, o visco (ou o visgo), ligado à ideia de inflexibilidade, ao estado de opressivo a aprisionar o homem, opõe-se à imagem do rio que traz em si o sentido de mobilidade, transformação, de liberdade, bem como a "experiência de ligação" obtida pela mistura da terra (sólido) macerada com á água (líquido), que se apresenta como uma massa pastosa, mas passível de ser transformada de acordo com os movimentos das mãos do artesão.

Persistindo no intento de compreender a imagem significativa do rio como componente dos diversos ambientes e espaços que constituem o enredo das duas obras analisadas, faz-se interessante retomar aqui a abordagem de Heráclito, que 
usa da alegoria do rio, bastante popular ainda nos tempos atuais, para explicar a mobilidade das coisas no mundo. Para esse filosofo pré-socrático, o homem não pode entrar por duas vezes no mesmo $\underline{\text { rio, }}$, no sentido de que, ao entrar pela segunda vez, não o fará nas mesmas águas, porque estas terão passado e virão outras águas em substituição, e que esse mesmo homem já terá também se transformado e adquirido outra maneira de ser e estar no mundo. Em comentário ao pensamento de Heráclito, Bachelard, em As águas e os sonhos (1997), acrescenta que, em sua profundidade, o ser humano não banha no mesmo rio por duas vezes porque "tem o destino da água que corre" (BACHELARD, 1997, p. 6), pois, de acordo com suas observações, a água e todas as imagens fornecidas por ela ao sujeito observador trazem a ideia de algo em contínuo movimento. Todo ser a ela dedicado ou misturado passa a metamorfosear-se num trânsito ininterrupto, pois "a água corre sempre, a água cai sempre, acaba sempre em sua morte horizontal" (ibidem, p.). A água é, em especial, para Bachelard:

o elemento mais favorável para ilustrar os temas da combinação dos poderes. Ela assimila tantas substâncias! Traz para si tantas essências! Recebe com igual facilidade as matérias contrárias, 0 açúcar e o sal. Impregna-se de todas as cores, de todos os sabores, de todos os cheiros. Compreende-se, pois, que o fenômeno da dissolução dos sólidos na água seja um dos principais fenômenos dessa química ingênua que continua a ser a química do senso comum e que, com um pouco de sonho é a química dos poetas (1997, p. 98):

O que antes era sólido, com a presença da água, converte-se em massa, perde a forma anterior, tornando possível, por meio da ação do sujeito, obter-se uma nova forma. Assim, a água permite uma experiência nova, inicial da matéria (Ibidem, p. 109). A água é capaz de amolecer determinadas substâncias, deixando-as sensíveis ao toque da criatividade humana. Assim, é da mistura da água com o sólido que se adquire a massa usada como matéria-prima pelo homem na construção de suas obras, as quais carregam, pela existência a fora, os rastros das mãos de seu criador, ou seja, a obra criada traz em sua essência as ideias, a criatividade e os traços da cultura a que pertence o seu autor. Nesse sentido, a presença da água, em especial, através dos rios, nas duas narrativas, pode indicar denotativamente toda a transformação experimentada pelas personagens, que apresentam mudança em si mesmas como uma opção de vida, impulsionadas pela 
insatisfação com o mundo à sua volta, que as conduz sempre a metamorfosearem ${ }^{23}$. Observa-se que a protagonista mato-grossense, orgulhosa de sempre se fazer diferente, demonstra-se como um ser em constante metamorfose de forma mais acentuada que a personagem portuguesa.

\subsection{Rios e o encontro das águas}

Tanto na narrativa mato-grossense quanto na narrativa portuguesa em estudo, observa-se que a imagem dos rios é um componente relevante na definição do espaço e do tempo onde se desenvolvem as principais ações das protagonistas desde criança à fase de adulta. Diante dessa verificação, com base na abordagem teórica bakhtiniana, em que a relação entre o espaço e o tempo é indissolúvel, o rio pode ser então definido como um cronotopo.

Dessa forma, o rio Luachimo, em Percursos, representa o cronotopo das experiências fundamentais na formação da protagonista quando criança e o rio Luena constitui o cronotopo em que estão situadas as ações efetuadas pela personagem na adolescência e na fase da vida adulta. O principal termo (Percursos) que compõe o título da obra, em sua significação vasta e profunda, refere-se à caminhada da protagonista, constituída por trajetos distintos: o da sua formação identitária, o de seu desenvolvimento da infância à maturidade, o percurso da sociedade dividida entre colonizado e colonizador no período das últimas décadas de agonia do Império Português e, necessariamente, o do próprio fluxo da narrativa com seus percalços, constituídos pelos fragmentos, antecipações e posposições de "reminiscências", ora quebrando, ora obedecendo à lógica da narrativa tradicional. Entretanto, a palavra "Percursos" refere-se, então, essencialmente ao próprio deslanchar existencial da personagem, identificado ao processo de tessitura da narrativa através da rememoração como elemento preponderante. A ideia de deslocamento, somada à diversidade de espaços geográficos distantes por onde transita a personagem ao longo do enredo, dá ao rio uma função cronotópica muito próxima ao da "estrada", definido por Bakhtin, tanto no texto de Wanda Ramos quanto no de Albues. Como o rio, a estrada pode dar a ideia de transitoriedade, de

\footnotetext{
${ }^{23}$ O uso da expressão "metamorfosearem-se" tem por motivação o significado simbólico da crisálida e da borboleta que aparecem em $O$ Berro para referir-se à transformação pessoal da protagonistanarradora.
} 
mobilidade. Sabe-se que o cronotopo da estrada está ligado ao cronotopo do "encontro", pois o segundo precisa do primeiro para acontecer. Como a estrada nos passa a ideia de ir e vir das pessoas, o que implica na mistura de pessoas e culturas de origens distintas, causando, portanto, com o passar dos tempos, um processo de transformação semelhante ao da acepção revelada pela imagem do rio nas duas obras em estudo. Assim, ambos podem se equivaler enquanto cronotopo relacionado à ideia da mobilidade e da mistura entre componentes culturais e étnicos distintos. Levando em consideração o papel do cronotopo da estrada na constituição do híbrido a partir das relações interpessoais, Bakhtin afirma que

\footnotetext{
a estrada ('a grande estrada') cruzam-se num único ponto espacial e temporal os caminhos espaço-temporais das mais diferentes pessoas, representantes de todas as classes, situações, religiões, nacionalidades, idades. Aqui podem se encontrar por acaso, as pessoas normalmente separadas pela hierarquia social e pelo espaço, podem surgir contraste de toda espécie, chocarem-se e entrelaçarem-se diversos destinos (2002, p. 349-350).
}

Como ocorre na memória da personagem principal de $O$ berro, as pessoas que participam desse encontro trazem consigo as experiências vividas em outros mundos; são histórias pessoais instituídas em contextos socioculturais deixados para trás no tempo e no espaço, que ali, apesar de todo isolamento e desconexão vivenciados pelos imigrantes nas parcas relações interpessoais, contestam-se, decompõem-se, mesclam-se umas às outras e se fazem presentes.

Em se tratando do encontro entre pessoas, o rio também pode constituir a metáfora do ponto de intersecção das mesmas, como ocorre em $O$ berro na imagem criada pela narradora do encontro do riacho do Cordeiro com o rio Hudson, em que denotativamente as águas mato-grossenses são misturadas com as águas de Nova York: "Pelo rio Hudson as folhas secas, aguapés, cipós brancos, que desembocam do meu riacho do Cordeiro, espremido entre pedras, arvoredos, touceiras de bananeira brava" (p.180). Nessa passagem, depara-se, em sentido figurado e até mesmo simbólico, com a imagem do encontro das águas do grande rio com as águas de seus afluentes. $O$ aspecto relevante dessa circunstância do encontro dos rios é que, na imagem criada no texto, é o córrego do Cordeiro situado em Mato Grosso que deságua do outro lado do Oceano Atlântico, evento totalmente inverossímil do ponto de vista físico e geográfico. Mas o que essa passagem faz é 
explicar ao leitor, numa linguagem alegórica, como se dá a relação dialógica entre culturas e pessoas tão diferentes, vindas de países distantes, mas dividindo um único espaço, a cidade de Nova York.

No texto de Albues, as águas, de modo geral, constituem imagens bastante significativas e frequentes, muitas vezes ligadas às questões existenciais levantadas pela narradora-personagem. Os vários rios denotam algo de natureza antropológica e psíquica referente ao homem, sua existência e seu comportamento. Nesse sentido, como pode o riacho do Cordeiro (Mato Grosso) desaguar no rio Hudson (Estados Unidos)? A narradora fala do encontro desses dois rios, tão distantes e diversos um do outro em vários sentidos, um destes, talvez, seria para expressar com mais habilidade a natureza e o resultado do encontro de pessoas de origens e culturas diversas no mundo atual, balizado pelo desenvolvimento tecnológico, em que a distância que separa as mais longínquas regiões do planeta é reduzida em decorrência do aprimoramento dos meios de transporte e meios de comunicação. Em consonância com a situação vigente do mundo atual, em que as distâncias encolheram, 0 ato de rememorar constitui uma das maneiras mais poéticas de avizinhar mundos geograficamente distantes, como fazem as protagonistas, a mato-grossense e a portuguesa, que tiveram um passado assinalado por várias viagens e pelo deslocamento de um país a outro. Nessas circunstâncias, viajar para dentro de si em busca do passado, por meio das lembranças, constitui um paradoxo com o sistema de vida das pessoas e de se relacionarem no mundo de hoje, pois o ambiente em que se vive atualmente se caracteriza pela solidão, pela transformação rápida do ambiente e espaço, um dos mais relevantes reforços da memória, e pelo uso de produtos descartáveis em substituição aos utensílios, cuja durabilidade no mundo de outrora transformava-os em um dos mais importantes apoios da memória, os quais eram transferidos muitas vezes de uma geração a outra. Assim sendo, a memória, acompanhada de uma de suas parcerias milenares, que é a "arte de narrar", não encontra hoje nenhum estímulo ou espaço acolhedor oferecido pela forma de vida do homem atual.

Se entendermos denotativamente o rio Hudson - identificado com Nova York, cidade que se compõe pela diversidade humana e cultural - como o rio que recolhe em seu leito águas de outros rios, a exemplo o riacho do Cordeiro, ambos se configuram como o cronotopo do homem contemporâneo, ou mesmo da constituição cultural e étnica do mundo híbrido atual, balizado pela multiplicidade e diferença. $\mathrm{O}$ 
grande rio, por ser o espaço de encontro de várias águas, equivale, assim, ao encontro de diversas pessoas, pois, em Nova York, inúmeros imigrantes vindos de várias partes do mundo se encontram. Assim, em se tratando do encontro entre seres humanos, o rio também pode constituir a metáfora do ponto de intersecção como ocorre em $O$ berro, na imagem do encontro do riacho do Cordeiro com o rio Hudson, em que, denotativamente, as águas mato-grossenses são misturadas às de Nova York.

Ao referir-se, no subtítulo, aos dois rios, Wanda Ramos o faz de modo a indicar um trajeto realizado ou a realizar por alguém: (Do Luachimo ao Luena). O uso das contrações "do" e "ao", juntamente com os parênteses, sugerindo uma expressão explicativa a delimitar o sentido do termo Percursos, define os pontos de partida e de chegada do trajeto indicado pelo título da obra. A ideia de movimento, de trânsito prioriza a instância temporal em detrimento da espacial não só pela questão alegada por meio do campo semântico e sintático do título, mas, em caráter distintivo, pela rica e complexa significação simbólica do rio na denotação do tempo. Há, ainda, uma estreita e forte relação de sentidos entre o fluxo das águas e as diversas trajetórias da personagem, delineadas na narrativa tanto em uma obra quanto na outra.

Nas duas obras, a função cronotópica do rio está intimamente relacionada à construção da identidade do ser humano contemporâneo, recriado nas personagens principais. É em $O$ berro que a questão identitária vai ser tratada com mais ênfase, pela forma como está tecida a referência feita ao rio e toda sua significação simbólica e metafórica. Ao riacho do Cordeiro e ao rio Hudson correspondem, em Percursos, também dois rios, Luachimo e Luena. Aos dois primeiros estão relacionadas as ações centrais da narrativa de Albues. Mas a função cronotópica dos rios no texto mato-grossense se alarga ainda mais por abarcar outros rios da região e, em caráter de relevância, as águas do Pantanal, cujas lembranças despertam os ressentimentos da protagonista, ligados a acontecimentos trágicos que lhe afetaram de modo significativo sua constituição identitária. Dentre eles, o trabalho escravo: "De novo as águas turvas do pantanal invadindo meus sonhos, alagando nossa vida, ameaçando levar para longe a tranqüilidade que sonhávamos duradoura. Eu sentia a aproximação da enchente, nada podia fazer para segurar a força das águas [...]” (BCN, p. 90). 
A alegoria constituída pelo desaguar do córrego do Cordeiro no famoso e imponente rio Hudson não condiz, em nível semântico, com a realidade do espaço físico-geográfico, mas com as questões de âmbito cultural do mundo globalizado, em que as distâncias que separavam os lugares mais remotos, graças aos efeitos da evolução tecnológica, encolheram-se. O mundo de misturas diversas atinge a dimensão cósmica quando o rio maior, volumoso pelo acolhimento de outras águas, mistura-se com o mar. O encontro do rio com o mar é um evento importante que não aparece descrito em nenhuma passagem do enredo, nem em $O$ berro e nem em percursos. Entretanto, observa-se que o encontro das águas doces com as águas salgadas constitui uma imagem fortemente explorada em outra obra de Wanda Ramos, em que as principais ações da narrativa têm como cenário predominante um estuário, já anunciado no próprio título da obra, Crônica com estuário ao fundo. É um espaço e um cenário constituídos simbolicamente pela mistura de componentes opostos, das águas doces com as águas salgadas. Assim, o estuário constitui um espaço em que predomina a ideia de variedade, de misturas, mar-terra-rio; é um espaço essencialmente marcado pela pluralidade por tratar de um ponto de chegada e de um ponto de saída de pessoas não de Portugal, mas da França, país relevante no que diz respeito à própria cultura disseminada nos dois últimos séculos que passaram por inúmeras outras nações do mundo, inclusive, o Brasil.

\subsection{Correntezas a pulsarem pela identidade do ser}

A afirmação da personagem Benjamim Barbudo - contemplada com a função de epígrafe da obra - de que há "muitos rios correndo dentro de nós, cada qual com sua natureza, podemos submergir ou flutuar, depende de como lidamos com suas águas" ( $B C N$, p. 103) é bastante significativa, no sentido de explicar a complexidade da natureza do ser humano e de suas identidades assentadas nesse parâmetro de multiplicidade e de um constante mover-se de que trata Hall (2006). Apoiada na ideia anunciada pelo sábio andarilho (Benjamin Barbudo), uma espécie de bruxo a iluminar-lhe a existência narradora-personagem, usa a metáfora imagem do rio para expressar a sua maneira de estar no mundo e de escolher os seus trajetos a cumprir: 
Ainda me debateria muitos anos na correnteza faminta daquele rio bravio que me fazia enveredar pelos labirintos da revanche, iludindome com promessas de alívio e apaziguamento, qual o quê! Até que um dia mudei de percurso, meu aprendizado com Benjamim Barbudo tenho que propalar. Busquei dentro de mim outro rio que deságua sereno entre aguapés, flores do campo, samambaias, avencas e buritis, remanso. Saltei de banda. Libertei-me (BCN, p. 162).

Nesse sentido, a narradora de O berro quer ressaltar, por meio da ampla e profunda significação da imagem do rio, as múltiplas possibilidades do ser, na maioria das vezes, explorado conforme o desejo do sujeito de decidir qual caminho deve ser seguido no circuito da vida. Os vários rios na passagem citada nos remetem aos vários caminhos a serem trilhados, dentre os quais uma pessoa pode efetuar suas escolhas. Trata-se, assim, da questão da identidade do sujeito, em que a presença do elemento rio, no plural, convida o leitor a atentar para os vários "eus" que existem dentro do ser, os quais são colocados em ação de acordo com as situações vivenciadas pelo sujeito e de acordo com suas opções, instituídas a partir do conhecimento e do pensamento elaborados conforme inúmeras experiências obtidas durante as várias fases da vida. Assim, na perspectiva da narradora albuesiana, a maneira impetuosa como cada "eu" vai sendo urdido em toda sua complexidade e assumido pela personagem assemelha-se ao rio e à sua correnteza a jorrar. Nessa construção semântica, o rio, definido pela sua grandeza e mobilidade, torna-se uma hipérbole a representar a abrangência da constituição identitaria do sujeito. Entretanto, os vários rios representam, então, as várias identidades assumidas pelo ser durante a existência. Apesar de toda força com que jorra as várias possibilidades latentes de identidades do ser dento da personagem, cabe a esta definir pelo que mais lhe convém. Hall (2006) discorre que a existência do indivíduo está entranhada na conjuntura sociocultural, de modo que a escolha do indivíduo com relação ao seu estar e ser no mundo não é livre, pois precisa estar em consonância com as condições e identidades coletivas de que faz parte. Da mesma forma que a língua materna não pode ser apropriada como um bem privado, a identidade precisa estar perfilhada à identidade coletiva e só se estabiliza como parte de uma rede cultural. Assim, a escolha da pessoa será garantida se estiver ajustadas as experiências compartilhadas nas relações intersubjetivas (HABERMANS, 1994, apud HALL, 2003, p. 77). 
A esta luz pode-se entender o perfil da personagem de Albues, que, em várias passagens do texto, revela-se como um ser capaz de driblar as formas convencionais de agir como mulher e dá uma nova direção a seu destino, desviando-se do caminho ao qual estava predestinada, de acordo com os preceitos do sistema político e social vigente, que, como já foi observado, não era dado às figuras femininas de sua família o direito de decidir sobre seu viver. A referida personagem sempre prima pelo diferente; desde menina, quando criticada pela família materna pela sua cor escura, aparência física, suas brincadeiras no meio masculino, vê na escrita e na leitura uma forma de refúgio na infância, que resulta em uma forma de superação na fase adulta. A escolha que fez quanto ao seu percurso identitário só vai fluir num espaço e ambiente caracterizados pela diversidade, pela constante presença do novo, pelo encontro com o diferente, que é Rio de Janeiro, São Francisco e Nova York, de modo que a sua mobilidade identitária e opção por uma nova maneira de ser da personagem só deslancha numa sociedade e cultura definidas pela multiplicidade e pelo que há de mais distinto nos lugares por onde viaja e mora, nos Estados Unidos e mesmo no Rio de Janeiro.

A personagem de Percursos, como muitas mulheres do contexto sociocultural e político no qual o referido romance está inserido, também desviou daquilo que the foi idicado pela ditadura de Salazar e pelo colonialismo português. A protagonista assumiu na narrativa, referente ao tempo da narração, a posição crítica diante da sua realidade social vivenciada, marcada pela violência contra o outro, e toma uma posição avessa aos objetivos pelos quais se encontrava em Angola no período da Guerra. E o trânsito de um rio ao outro, figuradamente expresso no título da obra (Do Luachimo ao Luena), representa mudança, transformação da personagem a caminhar numa direção oposta ao que o colonialismo esperava da sociedade. Sem entrar em choque com os moldes culturais e coletivos vigentes definidos pela imobilidade, a protagonista de Percursos passa a compor um grupo de mulheres delineado por novas relações interpessoais a se constituírem na contramão do sistema social. Diferente do que ocorre na obra de Tereza Albues, em Wanda Ramos, o rio da infância e o rio da vida adulta possuem praticamente o mesmo porte e dimensão geográfica. Mas se o rio Luachimo apresenta-se, de certa forma, distante da personagem, pois a menina não consegue estabelecer relação de afetividade e proximidade com o mesmo, considerando que quando criança, sua liberdade limitava-se apenas ao espaço doméstico, o rio Luena mantém um outro 
perfil em relação à protagonista, que, quando adulta, banha em suas águas, procurando aliviar sua aflição e tormento. No ambiente caracterizado pelo forte calor e poeira, a denotarem todos os problemas, angústias e conflitos vivenciado pelas pessoas em Angola, o frescor das águas do rio Luena traz à personagem conforto e bem-estar, o que ameniza seu sofrimento, simbolizado pelo "arame farpado", que, conforme já fora assinalado, caracteriza aquela situação dramática e de hostilidade para com o sujeito. Desde a adolescência, a heroína de Wanda Ramos estabeleceu uma relação de cumplicidade com o rio Luena, o qual compôs, como elemento preponderante, o cenário e o ambiente acolhedores de seus encontros amorosos, como se observa nesta passagem: "Furtava-se quando podia à vigilância dos pais [...] ao abrigo do rio e da vegetação cúmplice, primeiro beijos de fogo e ternuras promissoras de muito que haviam..." (p. 52).

A relação entre a personagem e o rio Luena vai assinalar, significativamente, outra questão relevante no que diz respeito à sua constituição identitária, bem como sua relação de pertença no âmbito social, tendo em vista que o mundo do colonialismo é um mundo dividido: de um lado, está o colonizado, de outro, o colonizador. Assim, no momento em que a protagonista já é adulta e retorna a Angola, o banho no rio Luena vai estabelecer, entre a protagonista e as nativas, um laço de proximidade quando estas, ao verem-na, "mulher branca lavando-se como elas no rio" (p.61), admiradas. Nesse momento, lavar-se nas águas torna-se símbolo da renovação e do renascer da personagem para uma nova fase da existência, enquanto um rompimento com o instituído pelo Império Português de sempre se colocar do lado oposto das nativas. Mesmo conduzida pelas circunstâncias favorecidas pelo colonialismo em ruínas, ao tomar banho no rio, ela age em direção ao diverso, colocando-se simbolicamente na mesma posição das negras, quebrando, de certa forma, a fronteira entre o colono e o colonizado. $O$ banho, como um dos principais ritos universais que sanciona uma nova fase da existência como o nascimento, a adolescência e a morte, pode ser considerado, então, como um rito de passagem a ser estimado nessa obra, considerando que o banho simboliza o momento de transformação pelo qual passa a protagonista e o espaço social e político de que faz parte. 


\subsection{Uma "viandante" a perambular pelo mundo}

No texto de Tereza Albues, a personagem-narradora trata, de forma clara e incisivamente, sobre sua própria maneira de se colocar no mundo, levando em consideração a sua índole como "viandante", característica esta adquirida através do convívio, na sua tenra meninice, com o místico e sábio andarilho Benjamin Barbudo:

[...] Benjamim era assim mesmo, meio esquisito, tenho que dizer. Ele sumia um tempão mas voltava sempre, dizia que Cordeiro era seu pouso de estimação, pausa para avaliar suas andanças. E também tenho perambulado pelo mundo, nos meus pés as marcas da estrada, vales e colinas, acampamentos ciganos, vilas, povoados à beira-mar, cidades imensas cravejadas de arranha-céus (p. 18, grifos nossos).

O perfil do referido personagem, juntamente com a identificação que há entre a protagonista narradora e o mesmo, sugere a existência de uma relação intertextual da personagem de $O$ berro e o conceito de narrador abordado por Walter Benjamin (1994), que tem por base a oralidade e a separação dos narradores em dois grupos quanto à sua natureza, o narrador viajante e o narrador sedentário, presentes na construção identitária do sábio Benjamim Barbudo enquanto personagem contador de histórias em $O$ berro. Assim, na constituição da narrativa em questão, muitos preceitos da narrativa tradicional se fundem com traços da estética moderna e contemporânea, como o fluxo da consciência e o uso do discurso indireto-livre.

A identidade da protagonista com o andarilho apresenta uma questão de relevância na medida em que, em consonância com a concepção benjaminiana, traços dos dois tipos de narradores (sedentário e viajante) coexistem de modo complementar na narrativa da obra, pois ao mesmo tempo em que a narradora conta suas histórias ligadas às suas à vida cotidiana, às suas raízes e tradições em Mato Grosso, conta também de suas viagens e paradas pelo mundo afora, sendo esta última uma tendência inspirada na figura do andarilho, que, por não ter paradeiro, trazia para o Cordeiro, seu ponto de parada, muitas histórias de outros lugarejos por onde perambulava.

Bejamim Barbudo seria o narrador "viandante". Assim, o termo viandante, usado por Nely Novaes Coelho (2002) para se referir às personagens femininas de Tereza Albues, tem muito a ver com essa protagonista de $O$ berro, que, ao mesmo 
tempo que acompanha o desenvolvimento do mundo contemporâneo repleto de inovações e transformações, autodefine-se como uma andarilha: Tenho vivido experiências incríveis que vão se incorporando à minha trajetória de andarilha" (p. 51). A definição de andarilha corresponde, assim, a alguém sempre a vagar por caminhos incertos, em especial, a pé, possivelmente por territórios não muito distantes, do ponto de vista geográfico. Já o termo viajante, além de tratar de pessoas que firmam sua existência a partir da prática do deslocamento espacial, refere-se sobretudo ao trânsito de pessoas por longas e consideráveis distâncias, que, por isso, gozam de maiores oportunidades de convivência com situações e lugares desconhecidos. Assim, tanto o andarilho quanto o viajante usufruem da oportunidade de, conforme argumenta Walter Benjamin, trocar experiências com pessoas de outros mundos por onde passam, ouvir o que lhes contam e também contar a suas histórias que conhecem ou experimentam. De cada ponto de parada, levam consigo outras novas narrativas oriundas do acervo cultural e de experiências vividas pelas pessoas habitantes das cidades e dos lugarejos por onde transitam. $\mathrm{E}$, assim, "viandante", como Nely Novaes Coelho bem nomeia a personagem albuesiana, é a palavra capaz de unir essas duas definições, $O$ andarilho, na sua gênese, de alguém que vive num contínuo e compassado caminhar, sustenta-se pela sabedoria e sensibilidade ao observar os diferentes mundos por onde transita e pela sua capacidade de se colocar diante da complexidade e dos mistérios do mundo, como faz a protagonista de $O$ berro. Se levarmos em conta que o desenvolvimento dos meios de transporte apequenou o mundo, reduzindo as distâncias entre lugares distantes, o ser viajante hoje se aproxima denotativamente do andarilho, pois o deslocamento interno deste nos espaços de caráter regional (de curta distância, isto é, perambular pelas redondezas), em que os meios de locomoção são mais lentos, pode ter a mesma duração de tempo e energia gastos que em uma viagem internacional a um país distante, de trajetos reduzidos pela velocidade, um dos paradigmas da vida moderna.

Desse modo, pode-se entender que a figura do andarilho, incorporado pela personagem Benjamin Barbudo, identifica-se com o deslocamento a curta distância, delimitado pelos confins do mundo de outrora, o Mato Grosso, e o viajante identifica-se como o transitar em nível mundial. Em síntese, na construção da personagem principal da obra, o regional e o mundial são elementos que se entretecem: o primeiro, ligado à sua distinção como andarilha, e o segundo, 
relacionado a seu lado viajante. Nesse aspecto, o regional, em termos de cultura e tradição - marcado pela estabilidade, situado na infância da protagonista e valorizado pela memória desta na sua maturidade - e o mundial, no sentido de multiplicidade, constituem a gênese da narradora-personagem no momento presente da narração. Ao mesmo tempo em que se volta para o seu "eu", a narradora o faz de modo a valorizar o outro. Ao focalizar suas raízes, dar ênfase a suas representações do passado, e o faz sem deixar de ressaltar o desconhecido, o diverso e sem perder de vista o presente e o futuro.

$\mathrm{Na}$ tenra infância, a protagonista de $\mathrm{O}$ berro tem, no sábio andarilho, uma figura que a ajuda manter-se em sintonia com o contexto e com a simplicidade da natureza, do primitivo e do mítico, por meio das histórias que ele era hábil em desfiar. Mas, na sua maturidade, a personagem transfere todo esse saber adquirido no passado, quando menina para o ambiente urbano, radicalmente oposto ao mundo de sua infância, por este ser composto de complexidade, mudanças rápidas de paradigmas, da multiplicidade, da mistura de inúmeras culturas e línguas oriundas das várias partes do mundo.

Os dois perfis da personagem, o da infância, ligado ao mundo regional, e o da vida adulta, contextualizado no espaço urbano, têm por base a sua disposição para o desenraizamento, considerando que o seu modelo inspirador tanto na infância como na fase adulta era Benjamim Barbudo. Se, de um lado, há, em sua formação, traços latentes da cultura mato-grossense, de outro, pulsa forte sua habilidade em adaptar sua vida numa "cidade global", como Nova York.

Ao definir-se como uma pessoa de muitas viagens e experiências, a protagonista o faz de forma a ressaltar pontos interessantes na sua caracterização quanto a seus desejos e realizações: suas viagens ganham, por meio das palavras e expressões metafóricas, uma denotação de desprendimento, de liberdade e de ausência de uma meta pré-definida pelo meio de onde veio. Como um barco à deriva, muito próprio de alguém que traz consigo os traços de uma vida perambulante, ela nunca se apresentou durante a narrativa vínculos inquebráveis a nenhum espaço físico e sociocultural, O verbo "perambular", usado no texto para referir a suas andanças, ressalta ainda mais a sua particularidade em procurar sempre qualificar-se como não só como "andarilha", mas como "peregrina" ou como "cigana". 
As marcas das estradas em seus pés denotam as transformações pelas quais passa a personagem em contato com as diversas realidades. Outras situações relevantes aparecem no texto de Albues a reforçar essa ideia dos inúmeros percursos seguidos pela personagem a definir essencialmente suas inúmeras experiências, como, por exemplo, o fato de a personagem comparar-se com uma cigana: "tome tenência cigana" ( p. 178), "a cigana que vive em mim" (p. 184). Sua identificação com o povo cigano ganha espaço em sua história de vida ainda na infância, no momento em que ela frequenta o acampamento cigano, instalado nas imediações de sua casa:

Mas eu me senti fascinada desde o primeiro momento em que os avistei, eram alegres, dançavam, comiam sentados no chão, dormiam em acolchoados coloridos estendidos na grama, soltos. A casa deles não era de tijolo ou adobo, podiam levá-la para onde quisessem, romper mundo, viajar por terras desconhecidas, livres como as estrelas do céu ( $B C N$, p. 69).

A protagonista de $O$ berro, ainda menina, embalada pela amizade estabelecida com uma garota de sua idade, filha de uma família de ciganos decide, numa tentativa frustrada, fugir com os ciganos, assim que "levantassem acampamento". No texto, como consta em passagens citadas anteriormente, raízes que prendiam a personagem a seu espaço de origem são substituídas pelos efeitos e marcas de suas experiências, de suas atitudes errantes e de suas viagens representadas de maneira figurada pelas "marcas da estrada" em seus pés (p. 18).

Como essa questão do trânsito do personagem é tratada com ênfase na narrativa albuesiana, faz-se necessária uma reflexão analítica sobre o valor semântico da referência feita aos pés da protagonista. Os pés, além de serem a base de apoio, simbolizam todos os caminhos percorridos pela heroína e todos os acontecimentos que lhe marcaram durante a vida. Da forma como está posto, fica subentendido que as marcas da estrada nos pés constituem-se uma metáfora da memória pessoal da personagem, denotando toda sua a conexão com o passado, mesmo que este não seja constituído pelo seu enraizamento em uma determinada cultura e sociedade.

As marcas nos pés também podem funcionar intertextualmente também como um diálogo com a Odisséia, de Homero, em específico, o episódio da cicatriz de Ulisses, tão bem explorado por Erich Auerbach (1994, 1-20), em que o narrador interrompe o fio da narrativa, deixando o leitor em suspenso, para esclarecer determinados eventos de outrora ou do futuro referidos rapidamente na narrativa. Trata-se, então, 
do elemento "retardador" da narrativa, que é o avançar ou retroceder do narrador, próprio do estilo de Homero, para "não deixar nada do que é mencionado na penumbra ou inacabado" (ibidem, p.03). Esses movimentos de ir e vir na narrativa de Albues, utilizados para esclarecer determinadas alusões, não se efetiva numa lógica como na forma clássica, mas de maneira indefinida e desordenada. $O$ fio dorsal da narrativa em estudo não apresenta um contorno que o distingue dos avanços, retrocessos e das descrições elucidativas de acontecimentos referidos rapidamente no corpo da narrativa, que fogem à linearidade e ao foco principal do mesmo. A relação das marcas nos pés da protagonista com a cicatriz de Ulisses é interessante por remeter os personagens (Ulisses e Euricléia) à memória de um fato remoto anterior aos acontecimentos focalizados pela epopéia. Assim, por mais máscaras e disfarces utilizadas no trajeto de vida, o indivíduo não consegue se livrar das experiências importantes que o marcaram. A cicatriz do herói da Odisséia funciona como um apoio chave da memória, para acionar as lembranças de uma experiência decisiva na definição do ser, apesar das mudanças e experiência vividas posteriormente pelo herói, que, além do mais, acaba de encerrar seu percurso como viajante no retorno à sua casa. Da mesma maneira, as marcas nos pés da protagonista de Albues, apesar de inexistente fisicamente, refere-se às suas experiências de viajante. Tendo em vista todo o valor semântico constituído pelas referidas marcas, estas constitui um dos eventos mais poéticos e significativos da narrativa a versar sobre a definição da heroína como "andarilha". Em suma, os pés são os componentes mais significativos do corpo da personagem, pois são eles capazes de transportá-la para outros espaços físicos, trazendo-lhe mobilidade, e, o que é mais importante, é capaz de transportá-la também, agora graças ao seu sentido metafórico usado no contexto da obra, para outros mundos por meio da memória e da imaginação. E para melhor entender essa constatação, faz-se relevante repetir a citação: "nos meus pés as marcas da estrada, vales e colinas, acampamentos ciganos, vilas, povoados à beira-mar, cidades imensas cravejadas de arranha-céus" (p. 18).

Se o cordeiro é o ponto de parada para Bejamim Barbudo e cronotopo central a situar a meninice da protagonista, Nova York é, no presente da narração, uma espécie de ponto de parada a partir do qual ela interpreta o mundo do passado e do presente como personagem-narradora. Conforme a perspectiva abordada no texto, na cidade nova-iorquina, as pessoas estão fadadas a viver 
predominantemente isoladas, cada uma à sua maneira, de forma que o processo de hibridização acaba prejudicado, juntamente com o processo de reconstrução identitária de cada indivíduo, que sempre está alicerçada na sua relação com o outro, nesse caso, praticamente quebrada. As culturas diversas se revelam em justaposição, em que não há uma inter-relação entre as diferentes formas de vida, num constante diálogo e transformações mútuas. O contato entre hábitos, culturas de pessoas de origem distintas que promoveria o pensamento reflexivo sobre a realidade fica, às vezes, impossibilitado de se efetivar.

Nesse aspecto, a personagem de $O$ berro coloca-se como distinta da maioria das pessoas que vivem em Nova York, a condição de imigrantes, pois estas não trazem, como ela, as marcas simbólicas dos percursos efetuados, cortando incisivamente suas relações com o passado com o mundo de onde veio. São pessoas que vivem como os diversos "Severinos internacionais":

Quantos Severinos eu tenho encontrado nos Estados Unidos, brasileiros que, com menos de dois anos de residência, dizem que esqueceram o português, têm vergonha da própria cultura, não querem se relacionar com os patrícios falam mal do Brasil, Tentam desesperadamente se americanizar macaqueando trejeitos $\mathrm{e}$ costumes que nada têm a ver com a sua formação ( $p .136)$

Trata-se aqui do imigrante ilegal e, nesse momento, é relevante a abordagem de Benjamin Abdala Júnior(2002), para quem este início do século XXI é marcado pelo deslocamento de um país a outro não só pelos representantes da intelectualidade, mas também pelo "conjunto da população trabalhadora" que perambula por vários países, procurando fixar-se "nas periferias dos grandes centros da globalização neoliberal. O resultado desse nomadismo vivido por um grande número de pessoas do mundo todo é a constituição do multidentitarismo" (ABDALA JR, 2002, p. 46). O vazio e a sensação de que falta alguma coisa só pode ser sanado se

o indivíduo se colocar como cidadão de vários países [...] o sentimento de que falta alguma coisa, carência só capaz de ser preenchida eliminando-se essa sensação de ausência, se o indivíduo se colocar como cidadão de vários países (pelo menos de dois). Mas isto nos parece importante: essa perspectiva de fronteiras múltiplas do homem dividido ou integralizado em pelo menos duas fronteiras, onde ele se desenraiza de sua terra de origem sem se enraizar na terra dos outros, coexistindo com grupos sociais migrantes de outras 
culturas, pode favorecer a criação de hábitos críticos, em razão dessa contraposição de perspectivas. Através desses contatos e ausências, próprios de uma população nômade, em constante circulação e deslocamentos, a identidade afirma-se ainda mais como um constante vir-a-ser, sem um ponto de chegada [...] (ibidem, p. 47).

Além dos acontecimentos de ordem mundial, responsáveis pelo constante circular de homens por inúmeros países, seus costumes e culturas, a personagem de Percursos se depara, de modo particular, com os eventos exclusivos de sua realidade sóciopolítica e histórica, relacionados ao processo de colonização e descolonização na África portuguesa, que provoca esse transitar de pessoas da Metrópole para a Colônia e desta para aquela.

O exercício de lembrar e narrar a história de vida constitui, para o ser humano, numa espécie de viagem para dentro de si, muitas vezes, denominada popularmente como viagem ao passado. Nesse sentido, pode-se afirmar que as protagonistas de Tereza Albues e de Wanda Ramos realizam uma viagem de volta ao lugar de onde vieram não através do trânsito no espaço, o que lhes é externo, mas através de suas memórias; retomam suas raízes, suas experiências passadas e efetuam uma nova leitura das suas percepções em relação ao mundo e ao meio em que viviam.

Ao voltar para si e relembrar o que viveu, a experiência própria narrada constitui para o sujeito desenraizado ou deslocado como uma forma de demarcar uma história, um lugar no mundo, reconstituir raízes, mesmo estando geograficamente distante de terra onde nasceu e cresceu. Nesse sentido, a recriação da trajetória de vida, por meio da memória e por meio da arte de narrar, possibilita a confirmação da identidade das protagonistas, cuja vida é assinalada pela itinerância e pelo descontínuo. É no "entre-lugar", configurado pela relação estabelecida entre a memória e o esquecimento, que se situa o fio condutor das narrativas. Assim, o que vem à tona no processo de rememoração são fragmentos, "pegadas", muitas vezes quase desfeitas, de um passado reminiscente do qual se retém apenas estilhaços na memória. O que resta da realidade lembrada são apenas impressões, leituras feitas pelas personagens de um tempo remoto de sua infância e juventude. No ato de contar a história de vida, restam ainda os sulcos, as fissuras e os entremeios vagos, deixados pela percepção descontínua do sujeito em relação ao vivido, pelas ausências da memória e pela incompatibilidade entre o 
mundo da linguagem discursiva e o mundo da existência, a serem preenchidos pelo ficcional, que dá "vida" e consistência à criação textual.

A narrativa tecida com enfoque nas lembranças pessoais se apoia também em eventos e imagens guardadas pela memória oficial, pelas tradições culturais de um povo ou de uma família e, especialmente, no imaginário, que, como vimos, viabiliza a tessitura da obra, dando contexto e completude ao mundo lembrado. É um "eu" que, por meio da rememoração e da construção da narrativa, reformula suas raízes, incluindo, muitas vezes, um percurso de errâncias por espaços vários, que está sempre com vistas para o novo e para o diferente que lhe chega quase sempre por meio do outro.

Observa-se, dessa maneira, que a personagem de Tereza Albues se dispõe a viver nos Estados Unidos sem cortar seus vínculos com a cultura brasileira (matogrossense) e a personagem de Wanda Ramos ora está em Angola, ora em Portugal, tendo suas raízes firmadas na cultura e na história dessas duas nacionalidades que a constituem. Esta pesquisa revela que foi o diverso, o encontro com o outro, com o diferente em suas experiências de vida que desestabilizou a formação tradicional concedida pela família (de origem portuguesa) à personagem de Percursos. Nessa abordagem, é importante lembrar que a personagem portuguesa também conta com sua formação acadêmica em Portugal, que, certamente, apesar de comportar o ranço de um governo reacionário e ditador, vai contribuir positivamente para sua interpretação do novo e do diferente que se deparara pela existência afora na construção identitária dessa "nova mulher"24 que se constrói no final da narrativa, como escritora que se dedica, conduzida por suas memórias, à construção de uma análise crítica do contexto social, político e literário impostos pelos colonizadores a seus colonizados.

\subsection{Um ovo a infiltrar-se ou um casulo a romper-se}

A protagonista-narradora albuesiana, como já foi apontado em outros momentos deste trabalho, vê como mérito a sua disponibilidade em estar sempre aberta a

\footnotetext{
${ }^{24} \mathrm{~A}$ qualificação da personagem como "nova mulher" se deve ao fato de que a protagonista portuguesa faz parte, como já vimos neste trabalho, de um grupo de pessoas que mesmo passando por uma formação voltada para os requisitos do colonialismo, da tradição familiar portuguesa, consegue fugir ao habitual vivido por suas iguais.
} 
novos conhecimentos e, consequentemente, a novas mudanças que possam ocorrer em seu ser. Para ilustrar essa habilidade da personagem em acatar o diferente, 0 desconhecido e transformar-se, Albues inclui na narrativa a imagem do ovo com casca a trincar, o que possibilita uma definição mais convincente da capacidade da protagonista em deixar-se penetrar por outras e novas formas de vida e de pensar como sujeito não unificado, pronto a refazer-se dentro de uma nova escolha e dentro de outra possibilidade de ser:

A unidade do eu sofre abalos; o ovo começa a trincar e não há forma de impedir infiltração na casca. Confronto com a nova realidade vai mostrar que os valores anteriormente usados na estrutura de nossa identidade têm que ser alterados. [...] É preciso ter elasticidade e trabalhar com ferramentas adequadas que, muitas vezes, rejeitamos ou não temos habilidades para manejar. ( p.203).

Nessa passagem, o sentido do ato de trincar e deixar se infiltrar apresentado pela imagem do ovo é bastante relevante na abordagem do processo da construção das identidades "múltiplas" referentes à personagem. O ovo é um símbolo universal da manifestação da gênese do mundo, pois contém o germe da vida, pois isso representa a realidade primordial que contém em germe a multiplicidade dos seres.

Como metáfora da própria protagonista, o ovo indica que a sua estabilidade identitária pode ser quebrada ou "infiltrada" a qualquer instante e surgir daí um indivíduo distinto do anterior, mas sem perder especialmente o seu referencial primeiro, de suas origens. A permeabilidade da casca transmite a ideia do contato do "eu" com o "outro" e a sua consequente modificação. Na metáfora do ovo, a gênese da vida é protegida por uma casca que permite a entrada de outrem, mas não descuidadamente, e sim de forma a passar pelo crivo protetor do "eu", simbolizado pela casca. Ao trabalhar essa metáfora, a narradora ressalta que os estímulos e os eventos externos que atingem a personagem se fazem não de forma desordenada, de acordo aos acontecimentos externos, mas sim gerida pelo individual e o que flui desse processo é a hibridação do ser.

No caso da Wanda Ramos, por mais que o pai procure proteger a filha do contato com os hábitos e os sistema de vida dos nativos, ainda assim, a menina é atingida em sua maneira de estar no mundo, pelos elementos definidores da vida e cultura dos angolanos. Não há uma metáfora específica e de sentido direto que 
expressa a proteção contra a cultura e os costumes do outro na narrativa, no entanto, percebemos tudo isso nos gestos de proteção e de tentativa de castração na atitude da família. Além disso, outro elemento da narrativa de Percursos que exerce a função de proteger a personagem principal contra a impregnação de tudo que a mesma viesse absorver dos hábitos e costumes do colonizado - enfim, da cultura e dos interesses alheios ao poder português - são as paredes da sua casa, grande e aparentemente bem estruturada. A imagem da grandiosidade da casa onde residia a protagonista e seus pais se opõe drasticamente à imagem do ovo e sua frágil casca, assim como se opõe a residência portuguesa em Angola, morada do povo colonizado. A resistência estrutural da casa a impedir qualquer infiltração denota os interesses do poder português de conservar sua forma de organização político-social-cultural e manter o seu império, mesmo que numa condição destoante em relação aos demais países colonizadores.

Outro símbolo que remete à multiplicidade indentitária da protagonista mato-grossense é a imagem da borboleta, muitas vezes presente na narrativa, a definir todo e qualquer processo de metamorfose. A borboleta é um símbolo da inconstância, da transformação ocorrida no mundo em que está inserida a personagem. A imagem da protagonista, voando no lombo da borboleta rumo ao mundo inatingível pelas outras mulheres oriundas de seu meio, forma um par de opostos com a imagem do visgo, que pode aprisionar a personagem do $O$ berro, prendê-la às coisas do passado, impedindo-a de efetuar sua mobilidade. Assim sendo, "visgo" se opõe à inovação do ser, representa a vida engessada, cativa do convencional, em oposição ao voo da borboleta, que representa a leveza e o livre trânsito em direção ao distinto: "saio voando no lombo das borboletas amarelas do pantanal" (p. 250).

Ao colocar-se como "cidadã do mundo", a protagonista de O berro convida o leitor a refletir sobre um modo de vida peculiar ao mundo contemporâneo, onde se delineiam indícios característicos do fim dos Estados Nacionais. de acordo com Hobsbawm (2007, p. 86), trata do "surgimento de uma era de instabilidade internacional iniciada em 1989, cujo fim ainda não se pode prever". Trata-se da diluição de fronteiras entre as nações próprias do mundo globalizado e, assim, a heroína de Albues está sempre propondo transcender as fronteiras do nacional: "Percorri o Brasil inteiro e outros países da América do Sul. Europa, Canadá, 
Estados Unidos. Tenho vivido experiências incríveis que vão se incorporando à minha trajetória de andarilha" (p. 53).

Em Percursos, a relação de pertença da protagonista conta não só com o alargamento dos limites de fronteira em sua formação inicial de Portugal para uma de suas colônias, Angola, mas também em relação a outras nacionalidades à medida que a narrativa, norteada pelo olhar da personagem, é construída não só pela língua portuguesa, mas também por expressões e mesmo passagens de textos que são escritas em inglês e em francês, além da citação de fragmentos de textos literários veiculando essas línguas

O desenvolvimento acelerado, para Hobsbawm (2007, p. 89), do processo de globalização, tem, nas últimas décadas, fortes efeitos no sentido de acentuar o movimento de mobilidade dos seres humanos. Crescem em escala extraordinária os movimentos transfonteiriços, tanto os de caráter passageiros quanto os de caráter duradouros. Com base na abordagem de Benedict Anderson (1998), o referido historiador ressalta que o principal documento de identidade do ser humano do século XXI não será a certidão de nascimento, nem a carteira de identidade do Estado nacional, mas o passaporte, que é um documento de efeito internacional (ibidem, p. 91)

A metáfora do berro carrega consigo a ousadia da personagem de Albues de não se contentar apenas com a nacionalidade brasileira ou, especificamente (o romance), em pertencer à literatura de Mato Grosso, mas estar à altura dos méritos da literatura universal. De literatura calcada no regional que, por discutir questões de âmbito mundial, o romance ultrapassa a esfera do local e/ou regional e aspira inserir-se no universal. Surge, assim, dessa ideia, a metáfora "do berro em Nova York". Mas, nesse aspecto, é importante acrescentar ainda que o referido romance é considerado por muitos críticos e estudiosos da produção literária de Mato Grosso como literatura mato-grossense. $O$ fato de ser escrito em Nova York, a autora residir nos Estados Unidos há mais de quinze anos e edificar sua personagem principal vivendo na maturidade em território estrangeiro não subtrai de $O$ berro sua pertença à literatura mato-grossense.

\subsection{O Voo}


O voo da protagonista de Albues em sua simbologia pode estar expressando a leveza de seu desprendimento em relação às convenções morais e culturais e até mesmo estéticas se considerarmos o discurso metalinguístico do texto analisado. Por se tratar de uma linguagem de natureza metafórica, o voar em $O$ berro não designa uma simples ação direta da personagem de voar, mas refere-se à sua maneira de estar e ser no mundo, ser e estar livre. "O voo que me liberta e abre as portas da criação me apazigua, me coloca em íntima conexão com a centelha divina que em mim cintila e me puxa para o infinito [...]" (p. 230). Em contrapartida, a natureza do voo da heroína de Wanda Ramos expressa uma ação própria da personagem, tendo em vista o contexto da Guerra Colonial. Mesmo a plainar no céu a vida que leva, constitui um peso de "África sobre o dorso" ( $P$, p. 77 ) para a protagonista. O voo no avião vem acompanhado de náusea, do barulho ensurdecedor dos motores, do vazio que a personagem principal sente dentro de si, diante dos atropelos e angústias da vida:

[...] a altitude quase rasante da avioneta assarapantando gentes e bichos vistos de cima minúsculos [...] deixem-me no meu cansaço, minha crónica náusea, meu vazio dentro da cabeça e grande sono a empurrar-me a nuca [...] deixem-me na minha náusea, minha maneira de estar comigo com o céu de angola entre mim e o meu destino, terra perdida no leste, desconcerto de estéril vida para vir [...] $(P$, p. 76-77).

A viagem de avião realizada pela heroína de Percursos é marcada pelo tédio, pela náusea. De modo distinto da heroína de $O$ berro, cujos trânsitos se dão sempre em busca de seu propósito existencial, a protagonista de Percursos alça voo para acompanhar o marido a trabalhar pelo colonialismo português, isto é, para atender aos desejos alheios, e não os seus.

Como consta no enredo de $O$ berro, transfigurada em borboleta, a personagem inexperiente, ao alçar seu primeiro vôo, sobe tão alto que termina "espetada" por uma antena fixada no topo de um prédio nova-iorquino. Cena esta bastante densa no diz respeito à compreensão analítica da construção dessa personagem ancorada na mobilidade do ser: 
rompi antes da hora as paredes ainda viva molhadas e quente de meu casulo [...] eu participava de uma sensação cósmica que de mim não mais se desgrudaria [...] Não tenho planos de aterrissagem. [...] Sobrevoando Manhatan, fui espetada pela ponta da antena prateada que fica no topo do Empire State Building [...] (p.216-217).

Em todos os momentos cruciais da existência da protagonista de Albues, nascimento para vida e nascimento para o mundo, para a vida adulta, como o homem contemporâneo que se depara com uma diversidade de nacionalidades, há uma espécie de perigo a rondar as suas investidas, $O$ perder-se nas alturas representa a força de seu desejo e de sua capacidade de agir e enfrentar o desconhecido inconsequentemente, num primeiro memento, mas sem o fim trágico que teve o mito grego. $O$ deslanchar aéreo da personagem mato-grossense permite estabelecer uma articulação com o seu imaginário arrojado, a projetar-se corajosamente no futuro, que é bruscamente interrompido, pela imagem do passado, portanto, salva pela memória:

Pendurada de cabeça para baixo, sinto a calosidade das mãos que me erguem no ar, o que é isso agora? Devo ser a atriz do filme King Kong, na cena em que o enorme gorila aparece segurando a mocinha que se esperneia em vão nas mãos peludas do animal. Em pânico, berro desesperadamente, [...] berro mais forte, já estou perdendo o fôlego, o esforço quase me estoura os pulmões quando inesperadamente ouço a voz veludosa de Siá Rumânia (p. 217).

Nesse trecho, há uma cena quase trágica, semelhante ao simbólico voo de Ícaro, que indica uma espécie de fusão entre os tempos passado, presente e futuro. A voz "veludosa" da parteira Siá Rumênia, ao nortear a protagonista, que pode ser comparada aos conselhos de Dédalo ao filho imprudente, vem de longe no espaço e no tempo, conduzida pela memória da protagonista. A voz mansa da parteira experiente surge, metaforicamente, em socorro aos "berros" desesperados da heroína principiante em seu primeiro, trôpego e audacioso voo nas alturas, o qual anuncia a busca insistente de um futuro desejado pela personagem. Esta, ao ser socorrida, como se acordasse de um pesadelo ao tomar consciência de si, transita do papel de personagem para a função narradora seguindo a força, a ordem e a 
trajetória de sua consciência, de sua memória, para expressar com precisão a relação de proximidade que ela, narradora-personagem, estabelece entre 0 nascimento para vida fora do ventre da mãe com o nascimento para o mundo distante de seu país de origem. O primeiro nascimento acontece em Mato Grosso e o segundo, em Nova York. A narradora simula uma cena em que a memória, no papel de mediadora entre diversos passados, o presente e o futuro, é capaz de abolir o tempo. Nesse caso, sua memória lhe traz de volta o comedimento e a cautela, o que leva a personagem de Albues a atingir o equilíbrio, façanha rejeitada por Ícaro por não ouvir os conselhos do pai, Dédalo, de forma que a protagonista não tem o mesmo fim que a personagem do mito grego, e assim termina por efetuar uma conquista sublime que afeta sua constituição identitária em constante mobilidade.

Para que a jovem inexperiente tivesse sucesso em sua investida e não passasse por um impedimento irreversível, foi necessário que as mãos da parteira experiente Ihe amparassem. Assim, a ação arriscada da menina aprendiz na escola da vida, a necessitar da ação experiente e ponderada da mulher madura, traz à tona uma reflexão que permeia a perspectiva do texto, na medida em que no mundo do pensamento, do conhecimento, do agir e da arte para que o novo tenha êxito é necessário que se tenha por alicerce, o que já foi constituído, convencionado, muitas vezes, até suplantado; no caso da produção artística construída numa estética inovadora, é a própria tradição a lhe preceder que lhe dá sustentação. Nessa narrativa de Albues, a base das novas atitudes e práticas está no passado interpretado aos olhos do presente por meio da memória da narradora, que se dispõe a lembrar sua existência passada. Para melhor entender essa passagem do vôo, é interessante ressaltar que o "berro" da personagem se opõe à tonalidade "veludosa" da voz da parteira. Assim, a voz da jovem principiante na escola do mundo é estridente, incisiva a incomodar o "outro" e a incitá-lo para uma ação de socorro e a voz da experiência acalenta, acalma, restitui o equilíbrio ao "outro".

Assim, o voo de Ìcaro coincide simbolicamente, de modo mais preciso, com o da protagonista de Albues, transfigurada em uma borboleta (recentemente saída de sua fase de crisálida) a voar. O voo da personagem mato-grossense apresenta uma conotação positiva de leveza e sublimação, enquanto que o da personagem de Wanda Ramos é afetado pelo peso da realidade do Colonialismo, da ditadura de Salazar e da Guerra em Angola. 
O impulso de voar em $O$ berro torna a protagonista metamorfoseada em borboleta cada vez mais leve, ao contrário em Percursos: ao voar, a protagonista sente-se cada vez mais pesada quanto ao seu ser e estar no mundo, pois o seu planar não constitui nenhum ato de transgressão ao preestabelecido, mas uma situação a que a personagem foi submetida e que lhe causa tamanho desconforto e revolta, expressos por meio dos vômitos, pois estes podem indicar o desejo não realizado da personagem portuguesa de reagir e recusar as imposições que thes são feitas pela família portuguesa e pelo Estado.

Ao ser despertada por uma voz vinda do passado, tem-se a impressão, num primeiro momento, de que a perspectiva da narradora a respeito da memória é de que o passado vem à tona tal e qual aconteceu, de forma pura, como afirma Bergson (1999), mas quando se observa a mistura que a protagonista realiza ao equiparar metaforicamente os dois nascimentos, ela traz em sua perspectiva a diversidade de outros passados, outras informações recebidas e guardadas na memória, como a do filme King Kong, sonhos e imaginário, de forma que, como argumenta Halbwachs (2004), é o presente da narradora de $O$ berro definido por suas relações sociais que norteiam a maneira como a mesma retoma e reconstrói as suas lembranças. Descrever o próprio nascimento como uma lembrança significa assumir as lembranças do grupo do qual fez ou faz parte como suas: "Não sei se este é o ponto certo para começar minha história, mas como tudo principia com o nascimento, [...] Repito o que me contaram, disso não me recordo" (p. 11). Entra aí, neste caso, a memória de outrem e do imaginário para construir as lembranças da protagonista enquanto autora de sua própria história.

É importante assinalar que a personagem portuguesa não conduziu os seus voos; esse fator pode ser relacionado ao seu vômito e toda reação orgânica de mal-estar que sofreu, psicologicamente ligados ao fato de não poder controlar seus movimentos no ar como mera passageira, já que o avião é conduzido sempre por um piloto. Essa situação de sentir-se impossibilitada de dar rumo à sua caminhada tornou-se, então, uma metáfora de uma condição mais ampla e profunda, peculiar à sua forma de ser e estar no mundo, constituída pelo fato de que, naquele momento, parte do contexto da Guerra Colonial, a personagem de Wanda Ramos não tem liberdade, sobretudo, como mulher, para dar rumo à sua própria vida. Ela e muitas das pessoas que ali se encontravam estavam à mercê das forças do colonialismo. $A$ narrativa revela que a protagonista não tem espaço, nem abertura, para caminhar 
conforme sua vontade, seus desejos, tanto na fase adulta, quando faz companhia ao marido, quanto na fase de criança, que, em momento algum, podia se furtar aos olhos e ordens do pai: "O pior foi quando mais tarde quis ir para as Belas-Artes e não deixaram e renegaram logo suas habilidades todas" ( $P$, p. 19). Em contrapartida, a personagem de Albues significativamente apresenta controle sobre seu voo, pois ela metaforicamente se transforma numa borboleta que, como se observa, é o símbolo da metamorfose. E, assim, o voo da personagem-narradora de O berro proclama a sua habilidade exemplar e enfatizada por si mesma de dar rumos novos à sua existência, diferenciando-se de todas aquelas pessoas com quem conviveu na infância e na adolescência em Mato Grosso: "Não foi difícil concluir que o estudo era minha arma, só através dele eu me distanciaria da opressão daquelas mulheres, haveria de conseguir respeito, admiração e liberdade pra fazer o que quisesse, dispunha de um trunfo poderoso nas mãos” (p. 54).

\subsection{A Memória e o vermelho: "vir a ser" e sua gênese}

É consideravelmente significativa nas duas obras a presença da cor vermelha, que possivelmente está em sintonia com os sentidos que constituem o texto. A ideia de transformação urdida com base na memória, na construção das personagens principais das duas obras em estudo enquanto seres em mobilidade pode estar representada no valor semântico do vermelho, considerando que a cor "encarnada" traz em si o sentido simbólico da vida, não a vida estagnada e enfadonha, como revela determinadas imagens de Percursos, contempladas com cor vermelha enquanto componente importante - como o vermelho fosco da poeira e o do sol a compor o ambiente das tardes tristes vivenciadas pela protagonista em Angola sob o poder do colonialismo -, mas a vida em movimento, em transformação.

Nas duas obras em estudo nesta pesquisa, o constante vir a ser das protagonistas, vinculado, especialmente, por meio da memória, à questão das origens e do trajeto de vida de cada uma delas torna relevante a análise da ampla e complexa significação da cor vermelha na abordagem dos textos que representa, de um lado, o princípio da vida, com seu brilho, com sua força, e, de outro, o fogo e o sangue, que são elementos essencialmente relacionados à existência do ser num eterno transformar-se. Podemos dizer que a terra fofa e a poeira vermelha da realidade angolana, vivenciadas pela personagem de Percursos numa perspectiva negativa, 
e, por isso, nessa acepção, devem estar associadas à angústia experimentada pela protagonista, podem, ainda, numa leitura mais ampla e atenta da obra, estar se referindo ao sentido simbólico da poeira e da cor vermelha, identificadas como força criadora. Assim, a poeira seria então como o sêmen e o pólen das flores, conjecturando o surgimento de um novo ser. A contradição, ou seja, a oposição de significados, faz parte do campo semântico de cada um desses dois símbolos: se o vermelho pode representar a guerra (destruição) e o amor (construção), a poeira também está relacionada tanto ao princípio da vida quanto ao morte, como se constata no texto bíblico nas seguintes passagens: "Tua descendência se tornará numerosa como a poeira do solo" (Gênese, 28, 14) "seco está meu paladar [...] tu me colocas na poeira da morte" (Salmos, 22, 16).

No que se refere à cor vermelha, em Percursos, o leitor depara-se com a poeira vermelha a cobrir a paisagem de Angola, a apagar os rastros da protagonista na estrada, a sujar a casa, a sujar as cortinas da pomposa residência da família da heroína na infância e se depara também com os criados negros a lustrar o chão de "cimento encarnado". A poeira vermelha ainda agrava o calor e reprime o ânimo da personagem tanto criança quanto adulta em retorno a Angola, na sua função de esposa de alferes: "Ver a noite aproximar-se cedo, muito cedo, anunciando-a o poente profundo e pesado que ali cobria de sangue a chana e os telhados de zinco de clarões vermelhos. Deixar apoderar-se dela a noite, de imediato aquela sensação de angústia que se instala no espaço à volta [...] (p. 60, grifos nossos).

É de "cimento encarnado" ( $P$, p. 11) o piso da casa da família da personagem principal no tempo de sua infância. Essa passagem é praticamente a única em que a cor vermelha aparece numa abordagem indicando beleza, algo positivo. 0 narrador, tomado pelo olhar da personagem, não deixa de assinalar que quem a faz brilhar é o criado negro; não encobre e nem ofusca os olhos como ocorre no caso da poeira proveniente da terra vermelha seca, que com força do vento aniquila o colorido da paisagem local e elimina a precisão da forma daquilo que se vê. Observa-se, ainda, que a mesma cor vermelha, especialmente o vermelho opaco da poeira, sempre aparece semanticamente ligada ao espaço e ao tempo balizado pela consternação e pelo desconforto experimentados pela protagonista, como vítima ou como testemunha, no momento em que ela revela a amargura e a aflição vividas pelas pessoas, sobretudo por aquelas que compõem a massa dos desfavorecidos, em decorrência da desigualdade social e econômica, configurada no sistema 
capitalista sustentado pelo colonialismo em Angola. O "sangue" que cobria a "chana", metáfora da poeira vermelha a cobrir a paisagem angolana no momento de conflito, dá ênfase à violência da Guerra a afetar a paisagem africana, no sentido de atrair a atenção do leitor para os vários tipos de barbárie exercidos pelo colonialismo contra o ser humano, espoliado e expulso do seu próprio espaço, da sua condição de ser.

Nesse sentido, os pés da protagonista, atolados na terra vermelha até os tornozelos, como consta nesta próxima citação, também pode relacionar-se à sua dificuldade de ação e, assim, de efetuar qualquer mudança no meio social delineado pelo colonialismo e especialmente pela Guerra Colonial, não só dela enquanto individuo, mas como parte de um coletivo:

os seres começam a cansar-se do peso de áfrica sobre o dorso, o barulho ensurdecedor dos motores a estimular a proximidade do vômito, o cheiro do combustível, estamos a chegar a Cuito Cuanavale, longa extensão de terra vermelha, dois hangares, os pés enterram-se na areia até ao tornozelo $[\ldots](P$, p. 77 , grifos nosso).

A imagem exterior a perturbar o olhar da personagem é reforçada também pelos elementos acessíveis a ela através de outros sentidos, como o auditivo, agredido pelo barulho dos motores, e o olfato, pelo repugnante cheiro do combustível. Todas essas sensações agressivas e desagradáveis à percepção da personagem levamna a um ápice dessa tormenta, uma espécie de colapso, que é o vômito, sendo que este, na situação mostrada, expressa o desejo contido da protagonista de transgredir, como já foi ponderado nesta pesquisa no item da análise do voo.

A correnteza e o frescor das águas do rio Luena se opõem à terra, que é caracterizada por um par de oposições constituídas pela "mobilidade" e "imobilidade": ao mesmo tempo que a terra, na sua simbologia, representa a estabilidade do solo que segura a raiz e é metáfora da casa que institui um dos cronotopos da existência humana ligado ao homem sedentário, a terra, de que fala o texto, também se caracteriza por ser "desprendida" a esvoaçar-se em mantos de poeira. Esta, transposta pela luz do entardecer, ganha mais tonalidade no vermelho, deveria indicar a mobilidade das coisas pelo valor simbólico, mas não é o que ocorre, pois a poeira sobre a paisagem angolana enrijece, paralisa tudo e a todos que por ela forem atingidos: 
Serpa Pinto fora de se morrer inerme e cansado à beira de absurda solidão. Corria nela um rio de cachoeiras por entre o desponte de ervas altas e canaviais e ressoava de noite o rumorejar surdo acima da imobilidade da terra. Era esta vermelha e desprendida que se levantava em vastas baforadas com os ventos violentos do entardecer [...] deixando tudo entumescido de poeira, mais vermelha ainda com o sol pondo-se [...] ( $P$, p. 61-62, grifos nossos).

$\mathrm{Na}$ imagem sugerida nessa passagem, vários elementos fundamentais da existência da vida no mundo aparecem compô-la como água, terra, sol e vento. É importante atentar, nesse caso, para o destaque do movimento, isto é, da "mobilidade" da água em detrimento da "imobilidade" da terra vermelha, na sua consistência ou no seu estado esvoaçado a paralisar a paisagem. No silêncio e no escuro da noite, o "entumecimento" da realidade pela poeira vermelha do fim do dia dá lugar aos rumores do movimento das águas do rio. O visual - representado pelo vermelho, sob a luz do sol a se pôr - assinalado pela luz do dia - cede espaço à musicalidade produzida pelo agitar das águas. O vermelho pode estar representando, então, o sangue oriundo do sofrimento humano criado pela guerra a angustiar as pessoas, mas que aponta, ainda de certa forma, para uma outra possibilidade de vida, se considerarmos que o vermelho da terra e da poeira tem uma relação de sentido com o nascimento de algo novo, surgimento de um novo ser, pois vermelho, terra e poeira juntos podem simbolizar um momento de passagem, de transição. A análise dessa citação anterior requer uma retomada da presença significativa do rio, como a própria metáfora da mudança, acompanhado da noite e de toda a atmosfera simbólica desta como pano de fundo dos acontecimentos que desembocariam no fim do império português.

É preciso observar que a luz vermelha do sol poente, apesar de compor um presente de dor e angústia sentida pelos que vivenciam aquele ambiente "profundo e pesado" (p. 60), anuncia um futuro de novos rumos para a existência daquelas pessoas que, como a protagonista, vivenciavam os bastidores da Guerra Colonial. Nesse sentido, a luz do sol intensifica o vermelho da poeira e dá brilho aos telhados de zinco, que, sob a poeira, ainda refletem "clarões vermelhos" (ibidem) e, assim, a luz e o brilho do vermelho, mesmo ofuscados pelo entardecer e pela poeira, apontam timidamente para um novo momento na história da personagem e do espaço de Angola. Com mais vivacidade e com o brilho da luz, o vermelho dá a ideia de ação e resistência que se impõe sobre a paisagem e, assim, numa 
perspectiva otimista, sugere a construção de uma nova realidade, mesmo a partir daquela atmosfera degradante.

No texto albuesiano, o vermelho predominantemente aparece expressando um sentido bastante complexo e pode ser relacionado semanticamente à origem e à gênese da vida, ao desenvolvimento da personagem-narradora e ao processo da rememoração e de construção da narrativa.

Nessa trajetória do vir a ser, da contínua metamorfose da personagem de $O$ berro, o vermelho, presente na citação a seguir, representaria a força da memória estabelecida pela narradora, que empenhada no processo de rememoração, faz com que suas lembranças de um passado e de um tempo distantes sejam recriadas de maneira que a paisagem mato-grossense, tempo e espaço longínquo, sobreponham-se ao cenário nova-iorquino, próximo do presente da narração: "O sol vermelho do Cordeiro vem despontando sobre as águas do rio Hudison, reavivando a tocha da Estátua da Liberdade e a chama da vida de meu coração" (BCN, p. 244). É como se houvesse uma sobreposição de imagens em que a imagem correspondente às lembranças do passado em Mato Grosso suplantasse, com o brilho do sol vermelho, a imagem do presente da narração. De acordo com o sentido metalingüístico dessa passagem citada, o realce do vermelho, disseminado pelo sol do Cordeiro sobre o pomposo cenário nova-iorquino, efetua-se graças à memória e ao poder estético da criação literária, do qual a obra em estudo é resultado. 0 vermelho representaria, nessa situação, também a eficácia da memória da heroína em romper as forças do esquecimento diante da realidade do mundo moderno (representado por Nova York), nada favorável ao ato de recordar e narrar o passado.

Se nesta narrativa mato-grossense a presença da cor vermelha está ligada ao sol nascente, à luminosidade e à superação da personagem, em Percursos, o vermelho da poeira agrava-se sob a luz do sol poente, compondo uma atmosfera ainda pesada, nebulosa do ambiente, assinalado pelo conflito bélico e pelo estado de angústia e de tédio experimentado pela personagem, mas que já acena timidamente para uma possível mudança no cenário angolano. O vermelho do sol nascente, na narrativa albuesiana, revela não o fim de algo, mas o começo de um momento caracterizado pelo despertar daquilo que se passou por meio da memória e o nascimento de um novo ser, que é a própria personagem, não mais dividida entre dois países, mas inteira, completa por meio do processo rememorativo e é através 
dessa personagem - que pode constituir a representação do homem contemporâneo - que, numa visão positiva, esses dois espaços (Brasil e Estados Unidos) e esses dois tempos (passado e presente) se conectam. Assim, o nascimento de um novo ser, a unidade dos espaços, do passado e do presente e a unificação do "eu" na sua relação com o "outro" pelo nascimento da narrativa analisada, da própria obra em que a origem, apesar de reconhecida pela crítica como mato-grossense, envolve essas duas nacionalidades (Brasil e Estados Unidos), portanto, ultrapassa o espaço regional.

Logo no início da narrativa, já se depara com o vermelho dos tijolos que revestem o chão da casa onde nasce a protagonista, que é extremamente expressivo, considerando o contexto em que essa palavra é incorporada ao texto, especialmente por se tratar de seu significado, em que a cor vermelha está ligada ao princípio da vida, no sentido de se impor ativamente diante da existência.

O início do capítulo "Um", de O berro, apresenta elementos simbolicamente opostos quanto à sua significação, que expressam a própria constituição da personagem principal. Ela nasce não como habitualmente nascem as demais crianças (no momento esperado, quando sua mãe está confortada em um leito), mas sim em um momento que a mãe transita pela casa. Se não fosse o socorro em tempo da parteira, a heroína teria batido com a cabeça no chão duro de "tijolos vermelhos" (p.11). Ao descrever o seu nascimento, a narradora-personagem constrói uma imagem assinalada pelo movimento e pelo trânsito - daquela que lhe dá a luz e dela mesma, que apressa sua primeira travessia da vida intra-uterina para a existência no mundo -, o que expressa, como já vimos anteriormente, seu lado nômade, seu contínuo perambular pela vida, o símbolo da eterna travessia, presente em sua vida desde o nascimento.

Em contraposição, o tijolo representa seu limite, mas também expressa proteção e ligação com suas raízes, às quais se mantém em sintonia (e não presa a elas), mesmo quando está em seu trajeto mais distante. Nesse sentido, é importante atentar para o significado simbólico e cultural do tijolo, considerando sua participação numa das mudanças sociais mais decisivas da humanidade, a passagem da sociedade nômade para uma a sociedade mais sedentária.

Há uma duplicidade de sentidos sugerida no fato de sua mãe estar em pé na hora do parto, deslocando de fora para dentro da casa: o estar em pé e em trânsito ao dar a luz sugere que a parturiente se encontrava num "entre-lugar", fora e dentro ao 
mesmo tempo do espaço doméstico, situação esta que simboliza, mais uma vez, essa hibridez característica da personagem principal de estar sempre a quebrar o habitual e de estar em movimento. A rede, onde repousava a mãe da protagonista tipo de leito muito utilizado pela heroína e os demais componentes de sua família, um costume antigo em Mato Grosso - de uso frequente pelos viajantes pela praticidade de ser transportada pelos viandantes - pode estar simbolizando a instabilidade na existência de seu usuário. Assim sendo, a ideia de inconstância expressa metaforicamente pelo referido utensílio pode ser reforçada por seu balanço, uma característica relevante. Em síntese, rede de dormir e toda sua gama de significação estão condizentes com a natureza peregrina da personagem de Albues. O único elemento da rede ligado às raízes, à gênese da autora, pode estar expresso na forma como ela acolhe e conforta a pessoa dentro dela, cuja posição se assemelha à forma como o feto se aloja no ventre materno. Entretanto, o balanço da rede contribui para simular o conforto da vida intrauterina, que representa os vínculos estabelecidos pela personagem com suas raízes, com a sua memória.

Tereza Albues começa e termina sua obra abordando esse significativo e crucial momento de travessia e existência humana, o nascimento. Essa travessia se faz presente em três momentos na narrativa, nos quais conta sempre com a presença significativa da cor vermelha: no primeiro nascimento há os tijolos vermelhos, no segundo, o vermelho do sangue jorrado no corte simbólico do cordão umbilical com sua terra mãe, e, no terceiro, também há o vermelho da "sabiá vermelha" (p. 245), que arremata a narrativa, cujo voo representa o desligamento da obra de sua autora.

No capítulo "Nove", último da obra, a narradora-personagem retoma o capítulo "Um" para fazer uma associação de sentidos entre o primeiro e o segundo nascimentos da personagem principal. Como acontecera no início do texto, o capítulo final iniciase com a notável oração em letras garrafais, para melhor chamar a atenção de seu leitor: "MINHA MÃE ME PARIU DE PÉ [...]" (p. 215). Mas, em seguida, no lugar de "[...] tanta pressa tinha eu de vir ao mundo que não lhe dei tempo [...]" (p. 11), surge: "[...] tanta pressa tinha eu de ver o mundo que rompi antes da hora [...]" (p. 215). A substituição, no segundo caso, do verbo "vir" pelo o verbo "ver", dá um toque poeticamente significativo não só pela semelhança sonora entre as palavras, mas, especialmente, porque a ação de ver indica a força do desejo da personagem em 
absorver para si outras realidades distintas daquela onde nascera e fora criada. No primeiro verbo, "vir", a personagem sai para o mundo; no segundo verbo, "ver", através dos seus sentidos (que alguém já chamou de janela da alma, os olhos), ela busca denotativamente o mundo para dentro de si:

[...] rompi antes da hora as paredes ainda molhadas e quentes do meu casulo e saí borboletando pelas encostas do Morro de Santo Antônio, paredões da Chapada dos Guimarães, Pão de Açúcar, Corcovado, Cordilheira dos Andes, Pirineus, Agulhas Negras, deslumbrada com o ouro do sol varando a transparência de minhas asas, o corpo ainda respingando o melado sedoso que me alimentara por nove meses. ( $p$. 215).

Os nove capítulos que compõem o texto de $O$ berro representam os "nove meses" de gestação, não apenas do bebê que fora um dia a personagem, mas do ser humano, da mulher que ela se tornou, de cuja formação ela, como narradora, trata nos nove capítulos da obra. Essa questão de gênese, focalizada com vigor poético pela escritora, não se refere apenas ao nascimento, à construção, à formação de seu personagem e à relação desta com o cosmológico - na medida em que a protagonista representa não só questões individuais, mas também questões complexas ligadas a um coletivo, à humanidade -, mas trata também da gênese da própria obra, cuja matéria-prima vem da memória e é consubstanciada na narrativa por meio das habilidades poético-literárias das romancistas, que lançam mão do seu imaginário, do seu potencial criativo para tal:

No amanhecer de minha existência eu participava duma sensação cósmica que de mim não mais se desgrudaria. Cai a primeira chuva que me lava e refresca, meu cordão umbilical ainda ligado à terramãe de certa forma cerceia meus avanços, há um limo na sua raiz provando antiguidade e solidez, meu ventre me segrega que, por esse tubo eu recebia a seiva que me mantinha viva, mas e agora? [...] a fisgada dolorosa que me dilacera a barriga me dá a impressão de que estou sendo golpeada por uma faca ou tesoura afiada, vejo tudo vermelho, [...] Sinto ardência de pimenta, tateio meu ventre, localizo um toco de tripa decepada, dolorido, sensível ao meu toque. É o que resta do meu cordão umbilical. (p. 216-217, grifos nossos).

De acordo com o sentido metalingüístico da questão do nascimento sugerido na obra, é possível entender que o nono capítulo - além de abordar no seu princípio o processo de afastamento da protagonista da sua terra-mãe para viver 
em solo estrangeiro -, na sua conclusão, versa com engenhosidade sobre a aquisição de autonomia da obra em relação à sua autoria. Nessa perspectiva de leitura, a substituição da metáfora do corte do cordão umbilical pela corda da harpa, dolorida para si mesma em sentido figurado e capaz de ferir os dedos de quem a dedilha, fica subentendida no texto a substituição, no final do romance, do segundo nascimento da personagem adulta, expresso pela cisão desta com suas origens, pelo terceiro nascimento representado não por um corte, mas pelo seu inverso, como uma forma superada de retomar a ligação com o país de origem simbolizado na figura do cordão umbilical, por uma ligação definida pela corda da harpa, único fio que, em vibração, mantém a personagem-narradora em sintonia outra vez com a sua terra natal, não como uma incapacidade de vida autônoma, mas pela maturidade da personagem (escritora) que se constitui com produção da própria narrativa: "A vibração da última corda da harpa, até agora emudecida, sobrepõe-se aos ruídos da manhã nova-iorquina" (p. 245). Daí troca-se o "berro" (segundo nascimento e manifestação de revolta da personagem) pela serenidade da música, pelo cântico de liberdade e pelo gorjeio da sabiá, incorporações metafóricas da personagem-narradora no final do romance. Acontece, então, o terceiro nascimento da personagem principal, que será melhor compreendido na conclusão desta pesquisa, em que "a criatura" (obra) se desprende de "seu criador" para ganhar vida própria junto a seus receptores (leitores), os quais, conforme seus conhecimentos, saberes e concepções de mundo, dar-lhe-ão sentidos múltiplos, mas sem escapar aos contornos demarcados pela gênese do texto.

Voltando a atenção para o segundo nascimento, o "limo", na "raiz" do umbigo "provando antiguidade e solidez" (presente na passagem da obra citada anteriormente), pode ter uma relação metalingüística com o terceiro nascimento, que é o da narrativa. Nesse sentido, o "limo", no contexto em que está usado, pode referir-se ao teor autobiográfico na textura da narrativa de Albues. Como o limo liga a protagonista à terra-mãe, ao seu passado vivido, o autobiográfico pode constituir o vínculo que estabelece um ponto de ligação entre a obra e a realidade extratextual. Mas o imaginário, o ficcional, implementados pela engenhosidade da romancista, dão à obra verossimilhança e leveza, o que the confere desprendimento da experiência vivida, sua matéria-prima utilizada na gênese que lhe atribuíra existência, enquanto criação literária. 


\section{CONSIDERAÇÕES FINAIS}

Tanto em Percursos quanto em $O$ berro, há determinados aspectos conclusivos da narrativa que enfatizam na sua constituição o expressivo ponto de chegada da protagonista, tendo como base o processo de rememoração e de edificação da obra na fronteira estabelecida entre o "eu" textual ficcional e o "eu" da experiência, entre a fiç̧ão e a memória. De certa forma, ambas as obras trazem no final uma abordagem metalingüística a tratar de sua própria gênese fundamentada na memória, cujo processo vai desde a construção e reorganização do individual subjetivo, até a inserção deste e da própria obra num todo maior configurado pela tradição cultural e literária, que implica no arranjo e na disposição deste particular, constituído pelo "eu" e pelo texto no mundo. As passagens finais dos dois textos trazem à tona determinados elementos significativos na sua tessitura e importantes para a conclusão desta pesquisa como: a relação dialógica dos textos analisados com outras produções literárias e demais formas artísticas; a presença metafórica da imagem do "eu" refletida no espelho importante para a compreensão do teor autobiográfico presente nos textos; a narrativa que se encorpa por meio da escrita engenhosa, acompanhada do imaginário ficcional, capaz de eliminar as fraturas, o descontínuo e fragmentário das experiências da vida contemporânea.

A protagonista de Tereza passa do berro ininterrupto do cordeiro, a manifestar-se no início e desenvolvimento da narrativa, à serenidade do gorjeio da sabiá vermelha no final do texto. O tijolo vermelho do chão da casa onde nascera a personagem e de onde parte o fio narrativo, que denota o limite, possivelmente fatal, para sua cabeça frágil de bebê recém-nascido, dá lugar no final dos acontecimentos ao sol vermelho. A narradora assume assim uma forma tradicional de iniciar um percurso autobiográfico, começando a contar a história pelo nascimento da protagonista. Considerando a importância do trecho inicial da obra, faz-se necessário citá-la novamente: "Não fosse a parteira entrar correndo e me aparar com as mãos experientes a minha cabeça teria estatelado no chão de tijolos vermelhos" (BCN, p. 11). Os obstáculos enfrentados pela personagem mudam de direção e de nível com o desenrolar de sua formação, a qual está interligada ao desenvolvimento da trama do texto, pois o chão da casa do evento inicial é 
substituído no último fato abordado pelo sol. O piso da casa, por ser o sustentáculo dos pés das pessoas, simboliza a base que sustenta a realidade, sobre a qual a narradora-personagem propõe edificar sua criação autobiográfica. Assim sendo, é nesse espaço que vai estar firmada a gênese da narrativa centrada na memória das suas experiências de vida.

De modo contrastante, o sol também chamado neste trecho final, demonstraria a superação das dificuldades no final do percurso pelo "eu" textual e criador. Por situar-se no sentido oposto às forças da gravidade terrestre, a imagem do sol e do céu representa o importante afastamento estabelecido pela personagem da realidade simbolizada pelo "chão". Mas o sol também constitui um limite simbólico e fatal quanto ao atrevimento do sujeito em querer lidar inconseqüentemente com sua habilidade de inventar, e para melhor explicar esta constatação é importante que se retome o mito do voo de ĺcaro, tratado no terceiro capítulo desta tese.

É relevante atentar para o fato de que é o mesmo sol do Cordeiro que brilha no cenário nova-iorquino, transportado no espaço e no tempo pela protagonista por meio da sua memória e especialmente pela maneira como a mesma interpreta as suas lembranças, no presente da narração, tendo por base as relações sociais estabelecidas pelo sujeito. O jogo de metáforas desenvolvidas em O Berro para definir a metamorfose vivenciada pela protagonista e sua identificação com a própria narrativa constitui-se seguindo uma lógica gradativa: o peso de seu corpo a atraí-la para o chão de tijolos, paradoxalmente, é trocado na vida adulta da personagem pela leveza e volubilidade da borboleta a se sustentar e a se perder no ar, e depois, na maturidade da personagem-narradora correspondente ao tempo da narração, a borboleta cede lugar à constante e determinada sabiá vermelha a cruzar com um vôo luminoso e rápido o céu da ilha de Manhattan. No enredo, o berro do cordeiro a perturbar aqueles que o ouviam é substituído pelo suave e sereno cantar da sabiá, que se confunde com o a suavidade do som da harpa (símbolo da harmonia cósmica - cuja última corda a produzir o som constituiria uma alegoria do ato de rememorar, podendo ser o "fio" de corda da harpa uma referencia denotativa ao "fio" de memória, usado na tecedura da narrativa de traços intimistas): "A vibração da última corda da harpa, até agora emudecida, sobrepõe-se aos ruídos da manhã nova-iorquina, enchendo o ar de melodias antanhas, algumas já esquecidas nos subterrâneos de mim, quase não as reconheço" ( $B C N$, p. 245). A 
melodia como metáfora da memória e da tessitura da narrativa, com base nas experiências pessoais - que é o caso dos textos analisados nesta pesquisa -, possui a capacidade de elevar a alma daqueles que a escutam, trazendo ao sujeito a serenidade e o poder de integrar o "eu" narrador ao todo da tradição literária e da cultura de modo geral, dando ao sujeito integridade e completude frente ao mundo demarcado pela fragmentação e pelo descontínuo.

A corda da harpa, em sentido figurado, ao trazer à tona as lembranças da personagem do mundo de outrora, rompendo os limites da distância espacial e temporal, expressa o vínculo desta criação literária com a tradição, considerando que a última expressão da narrativa, cuja tonalidade poética produz uma sensação de leveza, ressaltada pela expressão conclusiva do texto albuesiano, "plena de graça e luz", parece fazer um eco com o conhecido poema de João Cabral de Melo Neto, "Tecendo a manhã", poema este que traz, dentre os vários temas suscitados pela sua abordagem, a temática da tradição cultural e especialmente a tradição literária e consequentemente da intersecção de diversas vozes expressa nos "cantos de galos" e na própria textura dos versos. No poema a passagem mais condizente com este final do texto de Albues é constituído pelos dois últimos versos: "A manhã, toldo de um tecido tão aéreo / que, tecido, se eleva por si: luz balão". A luz neste contexto representa clareza, engenho, determinação nas decisões e maturidade da heroína, em paradoxo à revolta expressa pelo "berro" emitido por ela mesma em momentos anteriores da narrativa: "De novo o berro descontrolável (...). Berrava com todas as minhas forças (...) O meu berro desembestou, foi bater na Estátua da Liberdade em Nova York, provocou rachadura nos pés e mãos da velha matriarca" ( $B C N$, p. 92). A natureza "descontrolada" e impetuosa do berro sugere a presença da emoção da personagem em detrimento da razão e do equilíbrio simbolizados pela luz. Esta aparece associada a objetividade marcada pelo distanciamento do "eu" em relação ao conteúdo narrado que, mesmo sendo abordado pela instância individual do "eu", alcança uma dimensão universal. Já "plena e graça" tanto quanto o "balão" - termo conclusivo do poema em questão - além de apresentar em si as nuanças da objetividade, refere-se à presença do imaginário fecundo, da fantasia, constituídos pela subjetividade próprio do enfoque pessoal estabelecido pelas protagonistas das obras: em $O$ Berro, o discurso em primeira pessoa e em Percursos, apesar do testemunho da vida pessoal aparecer mediado pelo narrador em terceira pessoa marcado convencionalmente pelo distanciamento do "eu" 
narrador em relação ao narrado, o discurso indireto-livre juntamente com outras habilidades discursivas dá ênfase a subjetividade que permeia a abordagem das experiências individuais.

A narrativa, confundida com sua própria criadora, comparada ao "cântico de liberdade" (BCN, p. 245), além de ressaltar a ideia de libertação do sujeito, manifesta um diálogo com a arte musical. O "toldo" composto pelos cantares dos galos torna-se uma "luz balão" a desprender-se do chão, libertando-se do peso que o mantém em terra firme ( sendo que esta simboliza a realidade em oposição ao imaginário, ao ficcional). A personagem de $O$ berro, transformada em sabiá, é capaz de alçar voo, sem se atrapalhar em vertigens e em inconseqüências de atos impensados como ocorreu com a borboleta, que terminou espetada numa antena de uma das mais altas torres de Nova York e que foi salva pela sua imaginação em sintonia com a memória a lhe fazer transitar pelo terreno da experiência, que é a evocação da voz da parteira - profissão, cuja sabedoria advêm da experiência - por meio do fluxo da consciência como recurso narrativo, que simula a próprio funcionamento da memória: "Sobrevoando Manhatan, fui espetada pela ponta da antena prateada que fica no topo do Empire State Building (...) berro desesperadamente (...) o esforço quase me estoura os pulmões quando inesperadamente ouço a voz veludosa de Siá Rumênia (...) a parteira está ocupada em me dar banho" (p. 217). Assim, a protagonista, identificada com uma borboleta principiante a voar inconsequentemente, ao desvencilhar por completo da realidade e da razão passa por uma situação de risco. Evento este que enfatiza o valor do equilíbrio entre o imaginário e a realidade.

O desprender-se do chão tanto pelo "toldo" em "Tencendo a manhã", quanto pela sabiá vermelha em $O$ berro, constituem uma alegoria que pode estar associada ao desprender da obra de arte da sua ligação direta com a realidade, rumo a sua autonomia, desvencilhando-se de seu criador. Ao ser comparada com a luz a criação literária reforça ainda sua autonomia e capacidade de iluminar o seu entorno, no sentido de agir no outro, dialogar com outros textos e fazer parte de um complexo maior de produções artístico-literárias. Reforçando a questão da relação dialógica do texto de Albues com a poesia, é relevante observar que a frase final da narrativa pode ser relacionada ainda a um outro metapoema importante da poesia moderna brasileira a tratar da autonomia da obra, que é "O Elefante" de Drummond: 
"Vai o meu elefante / pela rua povoada, / (...) / É todo graça, embora / as pernas não o ajudem..." (2001, p. 105, grifos meus).

Ao voar "ao encontro das antigas companheiras" (p. 245) o "eu" da narrativa na conclusão do texto de Albues - não mais cordeiro, não mais crisálida, não mais borboleta, não mais música ou cântico como fora identificado no corpo do texto - incorporado na figura da sabiá vermelha, além de reforçar a ideia de autonomia do texto pelo seu sentido metafórico e metalingüístico, trata especialmente da inserção desta obra como parte integrante de uma rede de textos interligados entre si, que encontra correspondência de sentido no "bando de aves do cerrado em migração" atraídas pelo canto (obra de arte) da protagonista transfigurada em sabiá, uma delas, e no encontro com as "antigas companheiras palpitantes". Questão esta que está figurativamente explicada no metapoema de Cabral: "Um galo sozinho não tece uma manhã: / ele precisará sempre de outros galos..." Assim, "eu" da narrativa se integra ao coletivo, constituindo uma unidade maior, marcada pela instância do coletivo. Ao ir ao encontro das companheiras atraídas por seu canto, a sabiá representa alegoricamente a própria obra em estudo e sua relação de pertença com a literatura mato-grossense, pois a ave não vai ao encontro de estranhos, ou de imigrantes oriundos de outras nacionalidades, mas das suas iguais.

Nessa proximidade estabelecida entre os aspectos textuais da conclusão do texto de $O$ Berro e a poesia, a figura da sabiá acena para outra relação intertextual. Nesse sentido, o texto de Albues estabelece, apor meio da ave símbolo do Brasil, um diálogo com a "Canção de Exílio", de Gonçalves Dias, bastante parodiada por outros autores e dona de uma abordagem poética que extrapola os quesitos da nacionalidade, tema enfatizado pela narrativa em estudo.

Ao tecer uma narrativa, construir ou reconstruir, por meio da memória em ajuste com a ficção, utilizando das lembranças de um passado entrecortado pela vida em trânsito, pelos traumas atuais da existência e pelos vácuos deixados pelo esquecimento, o "eu" constrói-se como unidade, uma estrutura a compor um tecido maior, formado pelo coletivo das produções literárias como um todo. Neste sentido, é interessante ressaltar a ponderação de Clara Rocha, para quem, "no plano estético, o herói autobiográfico é uma recriação, a combinação entre uma pessoa real e uma pessoa inventada, o processo simultaneamente de auto-descoberta e de modelação de uma imagem" (1992, p. 49). Escrever para aquele que se vê longe de 
sua terra de origem é uma espécie de lugar para viver. A escrita torna-se para quem vive distante da pátria uma espécie de lar, amparo e conforto (SAID, 2003). Para 0 imigrante como um ser descontínuo, separado de suas raízes, o ato de escrever e de rememorar restituiria ao sujeito um "passado" alinhavado, enquanto discurso, considerando que a escrita intimista daria unidade aos fragmentos da descontinuidade de sua existência, definida em sua identidade, o que resultaria na construção de um percurso. O romper com fragmentário, delineado no texto de Albues, acontece também do ponto de vista do geográfico, global e cósmico, na medida em que a memória, e a habilidade da criação literária, juntamente com o processo de maturação da escritora, permitem à narradora-personagem unir simbolicamente, justamente na fase final da narrativa, o "solo norte" ao "solo sul em louvores à mãe Terra, uníssonos" de forma a dar unidade ao mundo no qual se insere o "eu" textual fruto da fusão entre o real e o ficcional.

Ao trazer o termo "Terra" grafado com inicial maiúscula, a autora dá ênfase especial à denominação do "espaço-mundo" do presente da narração, em que o "eu" da narrativa se situa e com o qual se identifica: o termo pode designar tanto a deusa Terra, de ampla significação mítica na cultura ocidental, quanto o planeta Terra. Passado e presente se integram nesse momento da narrativa, assim como os espaços mais longínquos se aproximam e toda e qualquer cisão é suprimida em prol de uma harmonia instaurada simbolicamente pelo som da harpa configurado em melodia. Resta uma única corda na harpa que, dedilhada pela narradora-personagem, designa figuradamente o processo de tecedura final do texto, demarcado pelo ato de rememorar. Tecida a narrativa, esta estabelece, de acordo com o enredo traçado numa linguagem peculiarmente figurada, uma espécie de sintonia com o universo, com o cosmo, o que contraria a natureza fragmentada e caótica da estrutura social contemporânea e, enfim, da própria realidade que se opõe à completude, coerência e organização do mundo ficcional. O voo da sabiá vermelha ao encontro de suas iguais equivalente, então, aos vários cantares de galos entretecidos no poema de João Cabral, que denota o estabelecimento das relações de pertença da protagonista de Albues. Em síntese, a narrativa em questão é fruto desse encaixe entre o "solo norte" e "solo sul", colocando assim a protagonista, na condição de imigrante há quase duas décadas nos Estados Unidos, em comunhão com sua terra de origem: Os vários "eus" estabelecidos pelo personagem ao longo de sua vida marcada pela inconstância das figuras simbólicas 
da crisálida e da borboleta, ganham coesão por meio da narrativa de cunho subjetivo. No final do texto, não é o "berro" (como um bradar de descontentamento da personagem diante das injustiças), mas a melodia expressa pelo o gorjeio da sabiá e pelo som da harpa que fazem com que a personagem entre em sintonia com o seu passado, sintonia esta que transcende do individual particular para o mundial configurado na "mãe Terra". É uma sintonia que aciona a ideia do "visceral" pela ação de evocar a corda da harpa que ao ser tocada fere o dedo, causando dor na protagonista como lhe causara dor o ato de recordar e interpretar as representações que tinha do passado. Essa ideia do visceral sugerido pela dor e pela metáfora da corda da harpa a lembrar denotativamente o cordão umbilical, designa substancialmente a essência do ser da heroína do texto. Lá no início do texto, o visceral está indicado pela ação de "berrar" e pela dor no ventre consumido pelos vermes, os quais, pelo significado simbólico, já no princípio da narrativa expressa a ideia de transformação da personagem no futuro, pois, como se sabe, o verme simboliza a passagem de um estágio a outro nos aspectos evolutivos de um ser.

A voz da protagonista-narradora que se anuncia desejosa de se manifestar, reconhecida na metáfora do berro na sua intensidade e ímpeto, entra em sintonia com o choro da personagem em seu nascimento. A referência ao som da harpa no principio do texto que "estilhaça o silêncio" (p. 12) pode ser associada ao primeiro choro do bebe ao nascer. Assim, como o nascimento do ser para a vida lhe causa dor, a criação literária assentada no processo rememorativo para se concretizar também passa pela dor: "A corda é tensa, dolorida, fere o dedo que a dedilha, fere a si mesma na aspereza da sua textura" (p. 245). A harmonia almejada pela protagonista só vai ser alcançada no final do percurso narrativo como já foi enfatizado, no momento coincidente com o presente da narração. Assim a libertação final da personagem é concomitante à libertação da obra, que se desvencilha de sua autora rumo à autonomia.

O deslocamento em busca do desconhecido está relacionado ao segundo nascimento da protagonista - que alarga seu referencial de pátria e de mundo nascendo para a realidade contemporânea, definida pela ausência de fronteiras devidamente esclarecido nos oitavo e nono capítulos de $O$ berro. Já a conclusão da narrativa (final do nono capítulo) aponta para uma espécie de terceiro nascimento que se dá no nível do discurso literário, constituído por meio da criação da obra de arte, materializada no som da música tão ressaltada no final do texto, momento em 
que se atinge a harmonia desejada pela protagonista em relação à sua produção artística. Trata-se então da serenidade do possível terceiro nascimento, uma espécie de transcendência, definida não pela presença do cordeiro a berrar em Nova York, mas pela maturidade e leveza da protagonista agora dedicada a sua criação, tendo por base suas experiências e seu imaginário. É interessante ressaltar que quando a protagonista se olha na figura da sabiá não é a pessoa real que ela vê, mas o seu reflexo nas águas espelhadas do Hudson. Ela incorpora a ave-símbolo do Brasil, cujo significado está ligado a sua relação de pertença, que tem a imagem refletida não nas águas do Pantanal, mas - no seu oposto em sentido geográfico, social, econômico e cultural - "nas águas espelhadas do rio Hudson", fato que alude a uma espécie de romper com as fronteiras do nacional.

É preciso ressaltar que a questão da instabilidade, mudança e transformação contínua da protagonista ainda persiste nesse momento final do texto, frisada pela presença da água e do rio a refletir sua imagem. Nesse sentido, observa-se que a imagem da sabiá não se revelou por meio de um espelho de vidro, mas pela água do rio constantemente a mover-se.

A presença simbólica e figurativa do espelho também se faz em Percursos e justamente no final da última "reminiscência" a compor o texto ("The mirrors, his impenetrable disguise" (os espelhos, o seu disfarce impenetrável. $P$, p. 94, tradução minha), e também aqui, como em Albues, se apresenta a metalinguagem, já que o texto em inglês é um verso do poema "Je Est un Autre" de Lawrence Durrell. Essa coincidência certamente diz respeitos aos traços autobiográficos a caracterizar as duas obras em que o "eu" é sujeito e objeto da narração. Para pensar sobre a complexidade significativa do espelho, faz-se necessário remeter ao mito de Narciso o qual, ao se apaixonar por sua imagem contemplada nas águas da fonte "é um duplo ser: simultaneamente o eu que olha e o outro que é olhado, o sujeito e o objeto do desejo. Assim, Narciso é, ao mesmo tempo, realidade e ilusão: tem um corpo verdadeiro, e enamora-se desse refletido" (ROCHA, 1992, 50, grifos nossos). Assim, frente ao espelho da água, Narciso tem diante de si a sua identidade e a sua duplicidade.

O mito de Narciso constitui um "complexo de cultura" na acepção bachelardiana, em que se conjugam dois motivos relevantes para a composição literária: "O do reflexo e o da fuga" (ROCHA, 1992, p. 51, apud GENETTE, 1966, P. 21). No caso do primeiro motivo, a imagem refletida de Narciso quando apreciada 
por ele, é "ele próprio e uma reprodução: o eu e outro estão ligados por uma identidade fantástica. Esse desdobramento tem o seu equivalente manifesto na escrita do eu em que a dupla, corpo e letra, mantém idêntica relação" (ROCHA, 1992, p 51). Já o segundo motivo, o da fuga, que está relacionado à instabilidade e mobilidade da imagem refletida, leva em consideração que a água que constitui o espelho através do qual Narciso se olha está sempre em movimento, sendo então capaz de surpreendê-lo com o diferente e o inesperado. Neste sentido, a pesquisadora Clara Rocha compara a instabilidade dá água a refletir a imagem do sujeito, muitas vezes a ser definida e completada por aquele que contempla, ao aspecto "traiçoeiro" da linguagem como um espelho do "eu". Diante da escrita confessional, o sujeito oscila entre o desejo de eternização e o de mobilidade: ora ele quer eternizar-se na escrita, ora ele recusa essa imagem fixada, chegando a não reconhecer-se nela, como o caso das duas protagonistas analisadas, pois ambas rejeitam mostrar-se por meio de uma imagem fixa, querendo revelare-se como seres em constante modificar-se, anseio que consta de modo acentuado na personagem de Albues.

Considerando que o papel das relações sociais na constituição da memória individual e a linguagem como uma ponte que estabelece a ligação entre o "eu" e o "outro" é importante que se reflita, a partir da acepção bkhtiniana, sobre o espelho como uma metáfora bastante significativa que finaliza os dois textos analisados:

Tudo o que me diz respeito, a começar pelo meu nome, chega ao mundo exterior à minha consciência pela boca dos outros (da minha mãe, etc), com a sua entonação, em sua tonalidade valorativo-emocional. A princípio eu tomo consciência de mim através dos outros: deles eu recebo as palavras, as formas e a tonalidade para a formação da primeira noção de mim mesmo (BAKHTIN, 2003, p. 374).

A escrita da autobiografia não prescinde apenas de um discurso direto do escritor sobre si mesmo; é indispensável que o escritor se posicione axiologicamente diante de sua própria existência de forma a suplantar os limites do vivido. Para isso é necessário que o sujeito se auto-objetifique, distanciando-se do vivido, olhando a sua existência de fora com um "outro". Na autocontemplação por meio do espelho, Bakhtin afirma que o "eu" nunca se contempla sozinho: "quando me olho no 
espelho, meus olhos olham olhos alheios; quando me olho no espelho não vejo o mundo com meus próprios olhos e desde meu interior; vejo a mim mesmo com os olhos do mundo - estou possuído pelo outro" (FARACO, 2008, p. 43). Assim, o "eu" se constitui na autobiografia a partir da consciência do "outro".

É preciso atentar para um detalhe relevante em que a figura do espelho em Percursos não se faz presente numa passagem comum da narrativa, mas através de relação intertextual estabelecida por Wanda Ramos que cita alguns versos do poema "Je est um autre" (Eu sou um outro) do escritor britânico Lawrence Durrell (1912 - 1990): “...In three European cities/ He hás watched me watching him./.../ He watches me now, working late,/ Briging a poem to life, his eyes/ Reflect the malady of De Nerval:/ O useless in this old house to question/ he mirrors, his impenetrable disguise" $(P, 94)^{25}$. Há uma intertextualidade dupla considerando que o título do poema "Je est un autre" é uma expressão chave usada pelo poeta francês Rimbaud (1854-1891), sem deixar de ressaltar que a referida expressão também é utilizada por Philippe Lejeune, para nomear uma de sua importantes obras, que versa sobre o testemunho autobiográfico, publicada em 1980. Ao analisar a expressão de Rimbaud, a versar sobre a natureza do sujeito da enunciação como mediador entre o "eu" e "outro", juntamente com o teor dos versos de Durrell, em que o jogo de olhares a refletir se faz presente numa forma que nos leva a pensar no jogo de espelhos que constitui a própria intertextualidade em que cada sujeito ao tecer relações de sua abordagem textual com o texto do "outro", o faz por se identificar com esse outro; assim, pelo intertexto, o "eu" se vê no outro.

Em Percursos, o dialogismo bakhtiniano se expande ainda mais com o fato de que as citações ocorrem na língua de origem da obra, inglesa e francesa, isto é, em idiomas de outras nacionalidades. Os fragmentos citados compõem obras de outros sistemas literários, diversos dos sistemas literários de origem das narrativas estudadas. E é, neste sentido, que a protagonista de Percursos, semelhante à de $O$ berro, se insere na dimensão mundial da literatura ocidental, cosmopolita. Através do conteúdo do poema citado, juntamente com ênfase a seu

\footnotetext{
25 “Em três cidades européias/ Ele me vê a olhá-lo./.../ Observa-me agora a trabalhar até tarde,/ Dando vida a um poema, os seus olhos/ Refletem a enfermidade de De Nerval:/ É inútil nesta velha casa perguntar/ Os espelhos, o seu disfarce impenetrável" (Tradução minha). Por se tratar de um aspecto com função textual preferi deixar no corpo da análise a citação em inglês tal qual aparece na narrativa.
} 
título, Eu é um outro (marcado pela intertextualidade), a protagonista de Wanda Ramos quer alertar o leitor para a sua multiplicidade e mobilidade, identificadas com sua multiplicidade identitária e a anunciada por Rimbaud em sua expressão anteriormente citada e por Durrell ao apropriar-se da mesma para dar titulo de seu poema, "Je est un autre". Revelando-se, assim, por meio da relação intertextual a presença constante do "outro", na escrita de cunho intimista. Nessa perspectiva, se faz relevante atentar para a relação de identidade, quanto às origens múltiplas, entre a personagem de Percursos e o escritor Durrell que nasceu na Índia, filho de indianos descendentes de britânicos. Mudou-se da Índia, juntamente com sua família para a Inglaterra, para Bournemouth, onde passou por diversas escolas no período de 1923 a 1928. Em 1930, muda-se para a França, onde deu início a sua carreira de escritor. Passou por diversos casamentos, morou na Grécia e exerceu a carreira diplomática, passando por várias cidades da Europa Oriental, Médio Oriente, Mediterrâneo e Argentina. Vê-se, ainda, que era um homem que preferia ser considerado como um cosmopolita.

O último capítulo das "Reminiscências" de Percursos apresenta, semelhante ao que acontece com a conclusão de $O$ berro, um diálogo significativo com a poesia e com a tradição das produções literárias. É também uma forma de inserir a obra no complexo coletivo da tradição literária e cultural: a protagonista não mais mediada pela voz do narrador, mas através de um discurso em primeira pessoa que conclui a última e "Quadragésima sexta reminiscência", como se tivesse concluído um poema e não uma narrativa. O capítulo metalingüístico "Proscênio" que arremata a obra, apesar de fazer parte de uma outra série de capítulos, quanto ao conteúdo e a estrutura, que fogem aos traços estruturais e narratológicos dos capítulos identificados por uma seqüencia numérica de "Reminiscências", dão continuidade ao teor metalinguístico da última "reminiscência" da narrativa: "Quadragésima sexta reminiscência”. Assim ao concluir também a série dos quatro capítulos de natureza metalingüística da obra estabelece, no plano da forma e do conteúdo do texto de Wanda Ramos, uma ponte entre o percurso metanarrativo, ou mais especificamente, "metamemória", e o percurso narrativo entrecortado pelas "reminiscências", distribuídas de acordo com o conteúdo abordado e não de acordo com a ordem numérica. Assim, ao tratar da construção do texto em um capítulo que, pela lógica interna estabelecida, deveria narrar as experiências de vida da 
personagem-escritora $^{26}$, o narrador (em terceira pessoa mediador da voz da protagonista) simula uma substituição do conteúdo autobiográfico por uma ponderação sobre a criação do próprio texto, fato que sugere a substituição do "eu" criador pela sua criação artística.

A parte final de Percursos ao tratar da criação artística, cujo eixo principal é a experiência de vida, o faz como um processo pesado, denso até muito próximo da fase conclusiva: “...não fora a cabeça cheia estes anos todos desse peso, cérebro em busca de rejeitar um dia qualquer sua carga inflamada e inamovível a caminho de Luanda..." (p. 96). Conforme a visão apresentada, a dificuldade alegada está no momento crucial da transformação do real, do vivido em arte: à medida que o trabalho artístico vai se encorpando no ritmo da habilidade das mãos do artista, a partir da desconstrução da matéria vivida em fragmentos, o peso inicial da edificação do texto vai se dissipando, sendo substituído figuradamente pela leveza das "bolhas" que surgem, no texto, a própria obra de arte, já delineada em oposição à realidade dos fatos vividos. O narrador usa da arte de esculpir como metáfora do ato da criação literária. A massa densa e informe, representação do real do início do processo criativo, é estrategicamente fragmentada pelo sujeito criador, como algo que possa sugerir denotativamente a estrutura fragmentada da narrativa de Percursos. Os diversos acontecimentos são lembrados e definidos denotativamente como uma espécie de massa coesa, em princípio despida de significação, mas depois desfeita em pedaços, os quais são individualizados e isolados pelo artista que dá "vida" e unidade significativa a cada um em particular. Depois de construída, a obra passa compor um todo complexo do já produzido no mundo da cultura e da arte, constituído por todas as produções artísticas já efetuadas. Assim o sentido do individual se completa na sua inserção na rede constituída pelo coletivo das demais produções já realizadas:

[...] esta massa posta a fermentar, crescida, pastosa, coesa, segregando bolhas aqui e além, únicos pontos alguma vez passíveis de começo, atacar por aí, paciente, febril, às vezes quase desistente, retirar-lhe bocados

\footnotetext{
${ }^{26}$ O termo "personagem-escritora" é utilizado não no sentido de confundir a personagem com a autora Wanda Ramos nestas circunstâncias da análise, mas pelo fato de que a protagonista no final da narrativa se define como uma escritora da própria obra em estudo.
} 
amorfos e moldá-los, justapô-los, sobrepô-los, um a um, avançar [...] as bolhas já são inúmeras, tornam-se reminiscências quase estanques, já perderam a rigidez do bloco de matéria, deixando já antever prováveis esculturas, laboriosa tarefa de goivas e cinzel $[\ldots](P, 96)$.

Possivelmente a personagem na função de escritora aqui nesta fase esteja trazendo uma ponderação sobre $o$ ato de criar, tendo em vista a participação do receptor no processo criador da obra de arte. Há primeiro caso o das "antigas bolhas-quase-esculturas a refundirem-se, a tomarem nova forma global e indiscriminável que se fecha no tempo" dificultando a decifração" represente a obra extremamente definida pelo seu autor, de significação rígida, fechada, num propósito de interpretação já previsto no seu processo de elaboração sem abrir para novas possibilidades de leituras. Já no segundo caso, em que pode ser identificado o texto em análise, em que a obra de arte enquanto "fragmentos quase acabados que eram as primitivas bolhas segregadas com o tempo pela massa informe começam a perder a configuração própria, a amalgamar-se de novo, a imporem-se como todo inesgotável" (Ibidem) torna possível a diversidade de leituras em diferentes épocas, abrindo espaço para a participação ativa do leitor a coadjuvar o autor em sua composição numa constante mobilidade de significação. Assim, nesse último tipo de produção artística, o texto traz uma ponderação sobre si mesmo enquanto uma obra sempre flexível e aberta a novas formas de leituras, capaz de adquirir novas significações com o passar dos tempos pois sua matéria não é rígida mas "uma "massa informe" sempre "a perder a configuração própria", (Ibidem) constituída essencialmente de um eterno vir a ser, assim como se delineia na narrativa o ser da protagonista não só de Percursos, mas também da protagonista-narradora de $O$ berro. 


\section{BIBLIOGRAFIA}

Bibliografia das Autoras:

ALBUES, Tereza. Pedra canga. Rio de Janeiro, Phiobiblioon, 1987. . Chapada da Palma Roxa. Rio de Janeiro: Atheneu/Cultura, 1990. . Travessia dos sempre vivos. Cuiabá, EdUFMT, 1993. . O Berro do cordeiro em Nova York. Rio de Janeiro: Civilização Brasileira, 1995.

. Dança do Jaguar. Paris: Zero Hora, 2000.

. À Sombra do Terrorismo. Latitudes. França, n. 13, déc, 2001. Disponível em: <http://revues-plurielles.org/ uploads/pdf/17 13 15.pdf>. Acesso em: 14 abr. 2009.

Desatino. Latitudes. França, n.13, déc, 2001. Disponível em: <http://www.revues-plurielles.org/ uploads/pdf/17 13 24.pdf>. Acesso em: 14 abr. 2009.

. Buquê de Línguas: contos. Cuiabá: Carline \& Caniato, 2008.

RAMOS, Wanda. Nas Coxas do Tempo. Lisboa,1970.

. E Contudo Cantar Sempre. Edições Inova, 1979.

. Que rio vem forçar a entrada desta casa? In: CHIOTE, Eduarda (Org). A Jovem poesia Portuguesa. Lisboa, 1979.

. Intimidade da Fala. Subterrâneo três, 1983.

. As Incontáveis Vésperas. Lisboa: Ulmeiro, 1983.

. Percursos (Do Luachimo ao Luena). Lisboa: Presença, 1985.

. Os Dias, Depois. Lisboa: Caminho, 1989.

. Litoral (Ara Solis). Lisboa: Caminho, 1991.

. Crônica com Estuário ao Fundo. Lisboa: Caminho,1998.

Bibliografia Geral 
ABDALA JUNIOR, Benjamin. Fronteiras Múltiplas, Identidades Plurais: um ensaio sobre mestiçagem e hibridismo cultural. São Paulo: Editora SENAC, 2002.

. De vôos e Ilhas: Literatura e Comunitarismos. São Paulo: Ateliê Editorial, 2003.

. Literatura História e Política: Literatura de Língua Portuguesa no Século XX. São Paulo: 2. ed. Ateliê, 2007.

ADORNO, Theodor. Posição do Narrador no Romance Contemporâneo. In: . Notas de Literatura I. São Paulo: Duas cidades, 2006. . Minina Moralia: Arte e comunicação. Tradução Artur Morão. Lisboa: Edições $70,1951$.

AGUIAR, Joaquim Alves de. Espaço da Memória: Um Estudo sobre Pedro Nava. São Paulo: Fapesp, 1998.

AMADO, Gilberto. História de minha infância. São Cristóvão: UFS, 1999. - Minha Formação no Recife. Rio de Janeiro: José Olympio, 1958. - Mocidade no Rio e Primeira Viagem à Europa. Rio de Janeiro: José Olympio, 1956.

ANDRADE, Oswald de. Um Homem sem Profissão: sob as ordens de mamãe. São Paulo: Globo: Secretaria de Estado da cultura, 1990.

ANDRADE, Carlos Drummond de. A rosa do povo. 23. ed. Rio de Janeiro: Record, 2001.

ANTUNES, P. Mais um de Tereza vem aí. Diário de Cuiabá, Cuiabá, p. DI,13 ago.1997.

ARENDT, Hannah. Entre o passado e o futuro. Tradução de Mauro W. Barbosa. 6. ed. São Paulo: Perspectiva, 2007.

ARIÈS, Phillippe. História social da criança e da família. 2. ed. Rio Janeiro: LTC, 1981.

ARGUEDAS, José Maria. Os Rios Profundos. Tradução de Glória Rodriguez. Rio de Janeiro: Paz e Terra, 1977. 
ARISTÓTELES. De la memoria y de la reminiscencia. In: Parva Naturalia. Traducción, introducción y notas de Jorge A. Serrano. Madrid: Alianza Editorial, 1993.

ARRIGUCCI, Davi Jr. "Móbile da Memória" In: Enigma e Comentário. São Paulo: Companhia das Letras, 1987.

AUERBACH, Erich. Mimesis. A representação da realidade na Literatura Ocidental. 2. ed. São Paulo: Perspectiva, 1976.

BACHELARD, Gaston. A Poética do Espaço. Tradução Antônio de Pádua Danesi. São Paulo: Martins Fontes, 1993.

A água e os sonhos: ensaio sobre a imaginação da matéria. Tradução Antônio de Pádua Danesi. São Paulo: Martins Fontes, 1997.

. A poética do devaneio. Tradução Antônio de Pádua Danesi. 2. ed. São Paulo. Martins Fontes, 2006.

BAKHTIN, Mikhail. Marxismo e Filosofia da Linguagem. 3. ed. São Paulo: Hucitec, 1986.

- Questões de Literatura e de Estética: A Teoria do Romance. 5. ed. São Paulo: Annablume, 2002.

- Estética da Criação Verbal. Introdução e tradução do russo de Paulo Bezerra. 4. ed. São Paulo: Martins Fontes, 2003.

BANDEIRA, Manuel. Itinerário de Passarada. In: Poesia e Prosa. Rio de Janeiro: Aguilar, 1958. V. II, p. 7-112.

BARBOZA, E. A escritora cuiabana lança hoje em Cuiabá e Escritora prepara um novo livro. A Gazeta, Cuiabá, p. 6F, 24 ago.1995.

A escritora, seus livros e suas andanças. Folha do Estado, Cuiabá, p. F3, 24 ago.1995.

BHABHA, Homi. O Local da Cultura. Belo Horizonte: UFMG, 2003.

BENJAMIN, Walter. Magia e técnica, arte e política: ensaios sobre literatura e história da cultura. 7. ed. São Paulo: Brasiliense, 1994.

BERGSON, Henri. Matéria e Memória: ensaio sobre a relação do corpo com o espírito. Tradução de Paulo Neves. 2. ed. São Paulo: Martins Fontes, 1999.

BOBBIO, Norberto. O Tempo da Memória: de senectute e outros escritos autobiográficos. Rio de Janeiro: Campus, 1997. 
BORGES, Vavy Pacheco. Desafios da memória e da biografia: Gabrielle BruniSieler, In: BRESCIANI, Stella; NAXARA, Márcia. (Orgs.) Memória e (res)sentimento: indagações sobre uma questão sensível. Campinas: Editora da UNICAMP, 2004, p. 287-311.

BOSI, Alfredo. Dialética da Colonização. São Paulo: Companhia das Letras, 1992. BOSI, Ecléa. Memória e Sociedade: Lembranças de Velhos. 2. ed. São Paulo: Edusp - TA Quirós, 1987.

BRAGA, Elizabeth dos Santos. O trabalho com a literatura: Memórias e histórias.Disponível em:http://www.scielo.br/pdf/\%0D/ccedes/v20n50/a07v2050.pdf Acesso em: 10 ago. 2008.

BRAIT, Beth (Org.). Bakhtin: conceitos-chave. 4. ed. São Paulo: Contexto, 2008.

BUENO, Aparecida de Fátima et al. Literatura Portuguesa: História, memória e perspectivas. São Paulo: Alameda, 2007.

CANDIDO, Antonio et al. A Personagem de Fiç̧ão. São Paulo: Perspectiva, 1972. . Mesa redonda de Literatura. Ciclo de debates do Teatro Casa Grande. Rio de Janeiro: Inúbia, 1976.

. Os Parceiros do Rio Bonito. 5. ed. São Paulo: Duas Cidades, 1979.

- Literatura e Sociedade: estudos de teoria e história literária. 7. ed. São Paulo: Ed. Nacional, 1985.

- Poesia e Ficção na autobiografia. In: Educação pela Noite e outros ensaios. São Paulo: Ática, 1987.

. A educação pela noite e outros ensaios. São Paulo: Ática, 1987.

. O discurso e a cidade. 2. ed. São Paulo: Duas Cidades, 1998.

. Tese e Antítese: ensaios. 4. ed. São Paulo: T. A. Queiroz, 2000.

A personagem do Romance. In: A Personagem de Fiç̧ão. São Paulo: Perspectiva, 2007. p. 53-80.

CALLIGARIS, Contardo. Verdades de autobiografias e diários íntimos. Disponível em: <http://virtualbib.fgv.br/ojs/index.php/reh/article/view/2071/0 >Acesso em: 20 ago. 2005.

CARDOSO, Maria Helena. Por onde andou meu Coração. Rio de Janeiro: Ediouro, 1980.

CAMPBELL. Joseph. O Poder do Mito. São Paulo: Palas Athena, 1990. 
COELHO, N. N. Dicionário Crítico de Escritoras Brasileiras. São Paulo: Escrituras Editoras, 2002. p. 614-617.

COELHO, Nelly Novaes. Literatura Feminina no Brasil Contemporâneo. São Paulo: Sciliano, 1993.

COUTO, Mia. Um rio chamado tempo, uma casa chamada terra. São Paulo: Companhia das letras, 2003.

CAMPELLO, ELIANE T. A. O Kunstlerroman de autoria feminina: a poética da artista em Atwood, Tyler, Piñon e Valenzuela. Rio Grande: Editora da Furg, 2003.

CANCELLI, Elizabeth. América da (des) ilusão - Ressentimento e memória. In: In: BRESCIANI, Stella; NAXARA, Márcia. (Orgs.) Memória e (res)sentimento: indagações sobre uma questão sensível. Campinas: Editora da UNICAMP, 2004, p. 471-489.

CANETTI, Elias. Língua Absolvida. São Paulo: Companhia das Letras, 1987.

CoOco, M. H. Pelas linhas e entrelinhas de Tereza. Folha do Estado, Cuiabá, p. 2A, Folha 3,14 out. 2005.

CAVALLARI, D. N. A arte de representar o outro: Silone e a criação de um universo polifônico. 2000. 317f. Tese (Doutorado em Letras) Faculdade de Ciências e Letras de Assis - Universidade Estadual Paulista, Assis. 2000.

DAMIÃO, Carla Milani. Sobre o Declínio da "Sinceridade": Filosofia e autobiografia de Jean-Jacques Rousseau e Walter Benjamin. São Paulo: Loyola, 2006.

DICKE, R. G. Nossa Escritora em Nova York. Diário de Cuiabá. Cuiabá, DC llustrado, p. D4, 18 jun.1995.

ECO, Umberto. Protocolos Ficcionais. In: Seis passeios pelo bosque da ficção. Tradução Hildegard Feist. São Paulo: Companhia das letras, 1994.

FANON, Frantz. Os Condenados da Terra. 2. ed. Tradução de José Laurêncio de Melo. Rio de Janeiro: Civilização Brasileira, 1979.

- Pele negra, máscaras brancas. Tradução de Renato da Silveira. Salvador: EDUFBA, 2008.

FREYRE, Gilberto. Casa Grande e Senzala: Formação da família brasileira sob o regime da economia patriarcal. 35. ed. Rio de Janeiro: Record, 1999.

GATTAI, Zélia. Anarquistas, Graças a Deus. 17. ed. Rio de Janeiro: Record, 1991. 
GAGNEBIN, Jeanne Marie. Memória, História, Testemunho. In: BRESCIANI, Stella; NAXARA, Márcia. (Orgs.) Memória e (res)sentimento: indagações sobre uma questão sensível. Campinas: Editora da UNICAMP, 2004, p. 85-94.

. Lembrar escrever esquecer. São Paulo: Editora 34, 2006.

GUINSBURG, Natália. Léxico Familiar. Rio de Janeiro: Paz e Terra, 1988.

GRUZINSKI, Serge. O Pensamento Mestiço. Tradução de Rosa Freire d' Aguiar. São Paulo: Companhia das Letras, 2001.

HAUSER, Arnald. História Social da Arte e da Literatura. Tradução Álvaro Cabral. São Paulo: Martins Fontes, 2003.

HATOUN, Milton. Literatura e Memória. São Paulo: PUC, 1997.

HOLANDA, Sérgio Buarque de. Raízes do Brasil. São Paulo: Companhia das Letras. 1995.

EAGLETON, Terry. Teoria da Literatura. Uma Introdução. São Paulo: Martins Fontes, 1983.

FARIA, Ângela Beatriz de Carvalho. A Libertação de Corpos Sitiados: o Feminino e a Guerra Colonial. Disponível em:

$<$ www.letras.ufri.br/posverna/docentes/64543-2.pdf> Acesso em: 30 jul. 2008.

FARIA, Â. B. C. Percursos e subjetividades femininas em cena, no período da guerra colonial. Revista Terceira Margem. Rio de Janeiro, n. 20, p. 11-22, jan./jul. 2009.

FRIDMAN, N. O ponto de vista na fiç̧ão: O desenvolvimento de um conceito crítico. Revista USP, São Paulo, n. 53, p. 166-182, mar./maio. 2002.

GUEDES, M.E. Wanda Ramos. Intimidade da Fala. Portugal, n. 69, p. 93, set. 1982. Fundação Colouste Gulbenkian.

Disponível em

http://coloquio.gulbenkian.pt/bib/sirius. exe/issueContentDisplay? $=69 \& p=77 \& 0=p$ Acesso: 14 abr. 2009.

GOLDAFARB, D. C. A memória pouco tem a ver com a verdade. Com ciência Revista Eletrônica de Jornalismo Científico. Campinas, 2003. Disponível em: <http://www.comciencia.br/entrevistas/memoria/delia.htm> Acesso em: 10 jan. 2008. GOMES, Renato Cordeiro. Eu, por exemplo... Uma reflexão sobre autobiografia precoce. O Eixo e a Roda - Memorialismo e Autobiografia, Belo horizonte, v. 6, p. 197- 217, jul.1988.

GUSDORF, Georges. Les Écritures du moi. Paris: Ed. Odile Jacob, 1991. 
KEHL, Maria Rita. Ressentimento. São Paulo: Casa do Psicólogo, 2004. (Coleção clínica psicanalística).

GOULD, I. A. F. Ficções do Eu colonial e pós-imperial: memória, identidade e família em O Esplendor de Portugal. Disponível em:

http://www.plcs.umassd.edu/docs/plcsfactsandfictions/ferreiragould.doc > Acesso em: 14 jun. 2007.

GUINSBURG, Natália. Léxico Familiar. Rio de Janeiro: Paz e Terra, 1988.

GRUZINSKI, Serge. O Pensamento Mestiço. Tradução de Rosa Freire d'Aguiar. São Paulo: Companhia das Letras, 2001.

HELENA, Silveira. Paisagem e Memória. Rio de Janeiro/São Paulo: Paz e Terra/Secretaria Municipal de Cultura, 1983.

HUTCHEON, Linda. Poética Pós-Moderna. Rio de Janeiro: Imago, 1991.

JAMESON, Fredric. O inconsciente Político: a narrativa como ato socialmente simbólico. São Paulo: Ática, 1992.

JORGE, Lídia. A costa dos murmúrios. 12. ed. Lisboa: Publicações Dom Quixote, 2001.

HALL, Stuart. A identidade cultural na pós-modernidade. 11. ed. Rio de Janeiro: DP\&A, 2006.

Da diáspora: Identidades e mediações culturais. Belo Horizonte: Editora UFMG, 2003.

HALBWACHS. Maurice. Los marcos sociales de la memoria. Rubí- Barcelona: Anthropos Editorial; Concepción: Universidad de la Concepción; Caracas: Universidad Central de Venezuela, 2004a.

. Maurice. A Memória Coletiva. São Paulo: Centauro, 2004b.

HAMON, Philippe et al. Categorias da Narrativa. Tradução de Fernando Cabral Martins. Org. e dir. de Maria Alzira Seixo, 2 ed. Lisboa: Arcádia, 1977.

HATOUN, Milton. Literatura e Memória. São Paulo: PUC, 1997.

HERZER. A queda para o alto. 14. ed. Petrópolis: Vozes, 1986.

HOBSBAWM, Eric. A Era das Revoluções (1789-1848). 6. ed. Rio de Janeiro: Paz e Terra, 1977.

HOBSBAWM, Eric. Tempos Interessantes: Uma vida no século XX. São Paulo, Companhia das Letras, 2002. 
. Globalização, democracia e terrorismo. Tradução de José Viegas, São Paulo: Companhia das Letras, 2007.

KAYSER, Wolfgang. Análise e Interpretação da Obra Literária. 2. ed. Coimbra: Armênio Amado Editor, 1958.

LARTHOMAS, Pierre. Le Genre narratif. Notions de stylistique générale. Paris: Presses Universitaires de France, 1998.

LEÃO, Emanuel Carneiro. O Esquecimento da memória. Revista Tempo Brasileiro. Rio de Janeiro, n. 153, p. 143-147, abr./jun. 2003.

LEJEUNE, Philippe. Entrevista com Phelippe Lejeune. Professora Jovita Maria Gerheim Noronha. Ipotesi: Revista de estudos literários: Juiz de Fora, v. 6. n. 2. P. 21-30. Disponível em: <http://www.revistaipotesi.ufff.br/volumes/11/apres.pdf> Acesso em: 22 fev. 2009.

LEJEUNE, Philipe. L'Autobiographie en France. Paris: Armand Collin, 1971/1998. . O Pacto Autobiográfico: de Rousseau à Internet. Belo Horizonte, Editora UFMG, 2008. p. 13-103.

- Definir autobiografia. In: MOURÃO, Paula (Org.). Autobiografia AutoRepresentação. Lisboa: Edições Colibri, 2003. p. 37-54.

LIMA, E. "A Travessia dos Sempre Vivos". Editado pela Editora Universitária, é o terceiro livro da escritora mato-grossense residente em Nova York. A Gazeta. Cuiabá, p. IE, 30 set.1993.

LIMA, Luiz Costa. Sociedade e discurso ficcional. Rio de Janeiro: Guanabara, 1986.

LORENZ, Günther W. (1973). "Diálogo com João Guimarães Rosa”. In: Diálogo com a América Latina. Tradução de Rosemary Costhek Abilio. São Paulo: Editora Pedagógica e Universitária Ltda, p. 315-355.

LUKÁCS, Georg. Teoria do Romance. Lisboa: Editora presença.

MACCARTHY, Mary. Memórias de uma menina católica. São Paulo: Companhia das Letras, 1987.

LUSTIG, Luis. O mais bonitinho perdeu o rabo: diário de um adolescente. São Paulo: MG Editores, 1984.

MACÊDO, Tania. Essas mulheres cheias de prosa: a narrativa feminina na África de língua portuguesa. In: LEÃO, Angela Vaz (Org.) Contatos e Ressonâncias - 
literaturas africanas de língua portuguesa. Belo Horizonte: Puc Minas, 2003, p. 155168.

. Angola e Brasil. São Paulo: Arte \& Ciência, 2002.

MAGALHÃES, Hilda Gomes Dutra. História da Literatura de Mato Grosso: Século XX. Cuiabá: Unicen publicações, 2001.

MAGNO, R. A mãe espacial ou memória revisitada (1997). Revista Garrafa. Rio de Janeiro, n. 5, jan./abr. 2005. Disponível em:

<http://www.ciencialit.letras.ufri.br/revista garrafa5.htm> Acesso em: 01 ago. 2007. MACHADO, Álvaro Manoel; PAGEAUX, Daniel-Henri. Da Teoria Literária à Literatura Comparada. 2. ed. Lisboa: Presença, 2001.

MACIEL, Sheila Dias. A Literatura e os Gêneros Confessionais. Disponível em:<http://www.cptl.ufms.br/pgletras/docentes/sheila/A\%20Literatura\%20e\%200s\%2 0g\%EAneros\%20confessionais.pdf> Acesso em: 22 jan. 2010.

MARTINS, V. L. R. A evocação da marginalidade: um estudo comparativo sobre Malagueta, Perus e Bacanaço, de João Antônio e Luanda, de Luandino Vieira. 2004. 236f. Tese (Doutorado em Letras - Estudos Comparados de Língua Portuguesa) Faculdade de Filosofia, Letras e Ciências Humanas, Universidade de São Paulo, São Paulo. 2004.

MATOS, D. Um padre abandona a batina por amor. Diário de Cuiabá. p. 33, 28 set. 1993.

MATOS, Olgária. A narrativa: metáfora e liberdade. In: Revista História Oral. Revista da Associação Brasileira de História oral, n. 4, jun.2001, p. 9-24.

MENESES. Adélia Bezerra. Memória e Ficção I/ (Memória: matéria de mimese). Do poder da palavra. Ensaios de literatura e Psicanálise. São Paulo: Duas Cidades, 1995.

MEIHY, José Carlos Sede Bom. Brasil fora de si: experiência de brasileiros em Nova York. São Paulo: Parábola Editorial, 2004.

- Globalização, Democracia e Terrorismo. São Paulo: Companhia das Letras, 2007. São Paulo: Parábola Editorial, 2004.

MICHELLE, Perrot. As Mulheres ou os silêncios da História. Tradução de Viviane Ribeiro. Bauru, São Paulo: Edusc, 2005.

MINÉ, Elza. Dois Portugais, Duas Angolas (Acerca de Percursos de Wanda Ramos), In: Maria Helena Nery GARCEZ; Rodrigo Leal RODRIGUES (Orgs.). O Mestre. São Paulo: Green Forest do Brasil Editora, p. 130-135, 1997. 
MOISÉS, Massaud. Dicionário de Termos Literários. 14. ed. São Paulo: Cultrix, 1999.

MOISÉS, Perrone Leyla. Altas literaturas: escolha e valor na obra crítica de escritoras modernas. São Paulo: Companhia das Letras, 1998.

MORLEY, Helena. Minha Vida de Menina. São Paulo: Companhia das Letras,1998. MOTA, Lourenço Dantas (Org.). Introdução ao Brasil. Um Banquete no Trópico 1. 4. ed. São Paulo: Editora Senac, 2004.

MACHADO, Dyonélio. Memórias de um Pobre Homem. Porto Alegre: Instituto Estadual do Livro, 1990.

MAGALHÃES, Isabel Allegro de. Capelas Imperfeitas: Configurações literárias da identidade portuguesa. In: RAMALHO, Maria Irene; RIBEIRO, Antonio Sousa (Orgs.). Entre ser e estar: raízes e discursos da identidade. Porto: Edições afrontamento, 2002, p. 307-347.

MAGALHÃES, Marion Brepohl de. O ressentimento do exílio: A estética da perda em Alfred Doblin. In: BRESCIANI, Stella; NAXARA, Márcia (Orgs.). Memória e (res)sentimento: indagações sobre uma questão sensível. Campinas: Editora da UNICAMP, 2004, p. 491-506.

MENDES, Murilo. A ldade do Serrote. Rio de Janeiro: Sabiá, 1968.

MOURÃO, P. Memória de Água. JL - Jornal de letras, Arte e Idéias. Linda-a-Velha, n.7, maio, 1981. Disponível em: <www.instituto-camoes. pt/arquivos/literatura/wandamemorias.htm>. Acesso em: 12 fev. 2005.

NABUCO, Joaquim. Minha Formação. 9. ed. Rio de Janeiro;Brasília: José Olympio/INL, 1976.

NADAF, Yasmin Jamil. Presença de Mulher: ensaios. Rio de Janeiro: Lidador, 2004.

NAVA, Pedro. Baú de Ossos. 5. ed. Rio de Janeiro: José Olympio, 1978.

. Balão Cativo. 3. ed. Rio de Janeiro: José Olympio, 1977.

NUNES, Caio Vilela. Partilhar Lembranças de Meu Mundo. Crônicas e Narrativas. Rio de Janeiro: Notrya Editora, 1994.

NUNES, José Horta (Org.). Papel da Memória. Campinas: Pontes, 1999.

OLIVEIRA, Paulo de Salles. Avós e netos nas classes populares: a recusa de não se sentir em lugar e a redescoberta de novo projeto de vida. In: BRESCIANI, Stella; NAXARA, Márcia (Orgs.). Memória e (res)sentimento: indagações sobre uma questão sensível. Campinas: Editora da UNICMAP, 2004, p. 269-286. 
OLIVEIRA, C. C. Wanda Ramos. As Incontáveis vésperas. Portugal, n. 69, p. 95-96, set. 1982. Fundação Colouste Gulbenkian.

Disponível em:

http://coloquio.gulbenkian.pt/bib/sirius.exe/issueContentDisplay? $n=69 \& p=77 \& 0=p>$ Acesso: 14 abr. 2009.

O' Connel, P. L. Una llamada colectiva por cobrar. El perpetuo exilio en Cobro revertido de José Leandro Urbina. Acta literária. Concepción, n. 26, 2001. Disponível em: $\quad$ http://www.scielo.cl/scielo.php?pid=S0717-

68482001002600004\&script=sci arttext $>$ Acesso em: 11 set. 2006.

PLATÃO. República. Tradução de Carlos Alberto Nunes. Belém: Universidade Federal do Pará, 1988. p. 614a-621d.

SARLO, Beatriz. Tempo passado: cultura da memória e guinada subjetiva. São Paulo: Companhia das Letras; Belo Horizonte: UFMG, 2007.

SANTOS, Boaventura de Sousa. Pela mão de Alice: o social e político na pósmodernidade. 7. ed. São Paulo: Cortez, 2000.

. Entre Próspero e Caliban: Colonialismo, pós-colonialismo e inter-identidade. In: RAMALHO, Maria Irene; RIBEIRO, Antonio Sousa. Entre ser e estar: raízes percursos e discursos da identidade. Porto: Edições Afrontamento, 2002, p.23-85.

SANTOS, Carina Faustino. A escrita feminina e a guerra colonial. Lisboa: Vega Editora, 2003.

SANTOS, Myrian Sepúlveda dos. Memória Coletiva \& Teoria Social. São Paulo: Annablume, 2003.

SANTOS, M. S. Sobre a autonomia das novas identidades coletivas: alguns problemas teóricos. Revista Brasileira de Ciências Sociais. São Paulo, Vol.13, n. 38, p. 1-21, oct. 1998. Disponível em: <www.scielo.br> Acesso em: 21 out. 2006.

SANTOS, Pedro Brum. Literatura, história e memória em Baú de Ossos. Fragmentum. Santa Maria, n.4, p. 7-37, out. 2002.

SANTOS, M. I. R.S. Wanda Ramos. Percursos (Do Luachimo ao Luena). Portugal, n. 69, p. 77, set. 1982. Fundação Colouste Gulbenkian.

Disponívelem:<http://coloquio.gulbenkian.pt/bib/sirius.exe/issueContentDisplay?n=69 \& $=77 \& 0=p>$ Acesso: 14 abr. 2009.

SARAMAGO, José. As pequenas memórias. São Paulo: Companhia das letras, 2006. 
SAVIETTO, Maria do Carmo. Baú de madeleines: o intertexto proustiano nas Memórias de Pedro Nava. São Paulo: Nankin Editorial, 2002.

SILVA, A. P. O "berro" de Tereza Albues em Cuiabá. Diário de Cuiabá. Cuiabá, p. E1, 24 ago.1995.

SILVA, J. A. V. Misticismo e Regionalismo em Tereza Albues. Folha do Estado. Cuiabá, p. 3A, 10 out. 2005.

SILVA, J. A. V. O Berro do Cordeiro n'Os Sertões euclidianos. In: XI CONGRESSO INTERNACIONAL DA ABRALIC: TESSITURAS, INTERAÇÕES, CONVERGÊNCIAS, São Paulo, USP. Artigos... São Paulo, USP, 2008. p. 1 - 8.

SILVA, Maria Angélica Wernek da. Memória e escritura no discurso feminino de Gabrielle Roy e Margarite Duras. São Paulo: FFLCH-USP, 2002.

SILVA, Márcio Seligmann. O local da diferença: ensaios sobre memória, arte, literatura e tradução. São Paulo: Ed. 34, 2005.

SILVA, Rodrigo Pereira Lopes de Faria e. Mosaico das memórias de um homem sem profissão. Dissertação (Mestrado). São Paulo: FFLCH-USP, 2004.

STADNIKY, H. P. Sonhos Bloqueados: a insurgência do vivido através de escritos autobiográficos. Disponível em: <http://www.anpuh.uepg.br/ xxiiisimposio/anais/textos/HILDA\%20P\%C3\%8DVARO\%20STADNIKY.pdf>

Acessado em: 02 de jun. 2008.

SMOLKA, A. L. B. A memória em questão: uma perspectiva histórico-cultural. Educação \& Sociedade. Campinas, v. 21, n. 71, jun. 2000.

OLIVEIRA, M. E. D. O Espaço da Memória em Carlos Drummond de Andrade. O Eixo e a Roda - Memorialismo e Autobiografia. Belo Horizonte, v. 6, p. 149-157, jul.1988.

PENTEADO, Yolanda. Tudo em Cor-de-rosa. São Paulo: Aurora, 1878.

PERSONA, L. Tereza Albues: sempre viva. Folha do Estado. Cuiabá, p. 3A- F3, 11 out. 2005.

PINTO, Cristina Ferreira. O Bildungsroman feminino: quatro exemplos brasileiros. São Paulo: Perspectiva, 1990.

PIÑON, N. A memória e a invenção têm uma fonte comum. Revista Continente Multicultural. São Paulo, n. 58, out. 2005. Disponível em: <http://www.nelidapinon.com.br/panorama/inte/pan entrevistas continente58.php> Acesso em: 3 fev. 2009. 
PY, Fernando. Prefácio, Marcel Proust: Dados Biográficos. In: PROUST, Marcel. No Caminho de Swann. À Sombra das Moças em Flor. Tradução Fernando de Py. 3. ed. Rio de Janeiro: Ediouro, 2004, p. 5-13.

PADILHA, Laura. Novos Pactos, outras ficções: ensaios sobre literaturas afro-lusobrasileiras. Porto Alegre: Edpucrs, 2002.

PEPETELA. Yaka. 4. ed. Lisboa: Dom Quixote. 1998. A Montanha da Água Lilás. Lisboa: Dom Quixote, 2005.

PORTO, Maria Bernadette (Org.). Identidade em Trânsito. Niterói: EdUFF/ABECAN, 2004.

PRIMO, Levi. É isto um homem? Rio de Janeiro: Rocco, 1988.

PRIORE, Mary Del. História das Mulheres no Brasil. São Paulo: Contexto / Unesp, 1998.

RAMA, A. Dez problemas para o romancista latino-americano. In: AGUIAR, F.; VASCONCELOS, S. (Org.). Angel Rama. Literatura e cultura na América Latina. São Paulo, EDUSP. 2001. p. 47-110.

REIS, Carlos. Técnica e Análise Textual. Coimbra: Almedina, 1981.

RAMOS, Graciliano. Infância. 22. ed. Rio de Janeiro: Record, 1986.

RAMOS, T. R. O. Por uma poética das memórias literárias. Com ciência-Revista Eletrônica de Jornalismo Científico. Campinas, 2003. Disponível em: $<$ http://www.comciencia.br/reportagens/memoria/11.shtml>. Acesso em: 10 de jan. 2010.

REIS, C.; LOPES, A. C. Dicionário de Teoria Literária. São Paulo: Ática, 1988.

REGO, José Lins. Meus Verdes Anos. 2. ed. Rio de janeiro: José Olympio, 1957.

REZENDE, Francisco de Paula Ferreira de. Minhas Recordações. Belo horizonte/São Paulo: Itatiaia/Edusp, 1988.

RIBEIRO, Margarida Calafate. Uma História de Regressos: Império, Guerra Colonial e Pós-Colonialismo. Porto: Edições Afrontamento, 2004.

. África no feminino: As mulheres portuguesas e a guerra colonial. Porto: Edições Afrontamento, 2007.

ROCHA, Clara. Máscaras de Narciso: Estudos sobre a literatura autobiográfica em Portugal. Coimbra: Almedina, 1992.

ROSÁRIO, C. C. O lugar mítico da memória. Morpheus - Revista Eletrônica em Ciências Humanas. Ano 01, n. 01, 2002. Disponível em: < 
http://www.unirio.br/morpheusonline/numero01-2000/claudiarosario.htm> Acessado em: 20 set. 2008.

SAID, Edward W. Cultura e Imperialismo. São Paulo: Companhia das Letras, 1995. . Reflexões sobre o exílio e outros ensaios. Tradução Pedro Maia Soares, São Paulo: Companhia das letras, 2003. . Fora do Lugar. Tradução de José Geraldo Couto. São Paulo: Companhia das Letras, 2004.

SANTIAGO, Silviano. O narrador pós-moderno. In: Nas Malhas da Letra. São Paulo: Companhia das Letras, 1989. p. 38-52.

SECCO, Lincoln. A Revolução dos Cravos e a crise do Império colonial português: economias, espaços e tomadas de consciência. São Paulo: Alameda, 2004.

SIQUEIRA, Elizabeth Madureira; COSTA, Lourença Alves da; CARVALHO, Cathia Maria Coelho. O Progresso Histórico de Mato Grosso. 3. ed. Cuiabá: Guaicurus, 1990.

SILVA, Maria Angélica Wernek da. Memória e escritura no discurso feminino de Gabrielle Roy e Margarite Duras. São Paulo: FFLCH-USP, 2002.

SIQUEIRA, Elizabeth Madureira. História de Mato Grosso: das ancestralidades aos dias atuais. Cuiabá: Entrelinha, 2002.

STEVICK, Philip. The Theory of the Novel. New York: The Free Preess, 1967.

SUSSEKING, Flora. O Brasil não é longe daqui: o narrador, a viagem. São Paulo: Companhia das Letras, 1990.

SUSSEKING, Flora. Literatura e vida literária. Rio de Janeiro, Jorge Zahar, 1985.

TACCA, Oscar. As Vozes do Romance. Tradução de M. Gouveia. Coimbra: Almedina, 1983.

TAVARES, Teresa. Um mundo que se quebra enquanto falo. Representações do espaço social e sexual na ficção narrativa de escritoras contemporâneas. In: RAMALHO, Maria Irene; RIBEIRO, Antonio Sousa (Orgs.). Entre ser e estar: raízes e discursos da identidade. Porto: Edições afrontamento, 2002, p. 349-380.

THOMAS, G. Tereza Albues era dona de uma verdade assustadora. Folha de São Paulo (Ilustrada). São Paulo, p. E7, 08 out. 2005.

TODOROV, Tzvetan. Les abus de la memoire. Paris: Arléia, 1995.

TODOROV, Tzvetan. O Homem Desenraizado. Tradução de Cristina Cabo. Rio de Janeiro: Record, 1999. 
VECCHI, Roberto. A insustentável leveza do passado que não passa: sentimento e ressentimento do tempo dentro e fora do cânone modernista. In: BRESCIANI, Stella; NAXARA, Márcia (Orgs.). Memória e (res)sentimento: indagações sobre uma questão sensível. Campinas: Editora da UNICAMP, 2004, p. 457-469.

VIEIRA, A. C. Morre Tereza Albues. Folha do Estado. Cuiabá, p. 8-A, out. 2005. VON BINZER, Ina. Os Meus Romanos. Alegrias e Tristezas de uma Educadora Alemã no Brasil. 5. ed. Rio de Janeiro: Paz e Terra, 1991.

WEIL, Simone. O Enraizamento. Tradução de Maria Leonor Loureiro. Bauru, SP: EDUSC, 2001.

WELLEK, René; WARREN, Austin. Teoria da literatura e metodologia dos estudos literários. São Paulo: Martins Fontes, 2003.

WILSON, Edmundo. Os Anos 20. São Paulo: Companhia das Letras, 1987. ZAGURY, Eliane. A escrita do eu. Rio de Janeiro: Civilização Brasileira, 1982 